\author{
Universidade de São Paulo \\ Faculdade de Medicina de Ribeirão Preto \\ Programa de Pós-Graduação em Genética
}

\title{
ANÁLISE DO TRANSCRIPTOMA DURANTE A ONTOGENIA DO TIMO
}

Danielle Aparecida Rosa de Magalhães 


\author{
Universidade de São Paulo \\ Faculdade de Medicina de Ribeirão Preto \\ Programa de Pós-Graduação em Genética
}

\title{
ANÁLISE DO TRANSCRIPTOMA DURANTE A ONTOGENIA DO TIMO
}

\section{Danielle Aparecida Rosa de Magalhães}

\author{
TESE APRESENTADA AO PROGRAMA DE PÓS- \\ GRADUAÇÃO EM GENÉTICA DA FACULDADE DE \\ Medicina DE RibeIRÃO PRETO DA \\ UniVERsidAdE DE SÃo PAUlO PARA OBTENÇÃO \\ Do Título De DOUTOR EM CIÊNCIAS, ÀREA DE \\ CONCENTRAÇÃO: GENÉTICA
}

Orientador: Prof. Dr. Geraldo A. S. Passos

Ribeirão Preto 
MAGALHÃES, Danielle A R.

ANÁlise DO TRANSCRIPTOMA DURANTE A ONTOGENIA DO TIMO.

RIBEIRÃo PRETO, 2007.

141 p. il. $30 \mathrm{~cm}$

Tese de Doutorado apresentada À Faculdade de Medicina de RibeirÃo PRETO, USP, ÀREA DE CONCENTRAÇÃO EM GENÉTICA.

ORIENTADOR: PASSOS, GERALDO A S. 


\section{Apoio e Suporte Financeiro}

Este trabalho foi realizado no Laboratório de Imunogenética Molecular, localizado no Departamento de Genética da Faculdade de Medicina de Ribeirão Preto (FMRP) - USP com apoio financeiro das seguintes entidades:

- Fundação de Amparo à Pesquisa do Estado de São Paulo (FAPESP) Processos nº3/00982-6 e 99/12135-9

- Fundação Coordenação de Aperfeiçoamento de Pessoal de Nível Superior (CAPES) - Processo 2983/05-2

- Conselho Nacional de Desenvolvimento Científico e Tecnológico (CNPq)

- Fundação de Apoio ao Ensino, Pesquisa e Assistência do Hospital das Clínicas da FMRP - USP (FAEPA)

- «Institut national de la santé et de la recherche médicale» (INSERM), Marseille - França. 


\title{
COM MUITO CARINHO
}

\section{À minha querida mãe...}

"Tudo o que sou e que sempre desejei ser, eu devo a meu anjo Mãe." Abraham Lincoln

Ao meu querido pai!!!

Luz do meu caminho...

À minha querida família!!!

Minha fonte de coragem e Razão do meu viver...

Ao meu namorado TOM,

Pelo apoio incondicional de todos estes anos...

\section{AMO MUITO VOCÊS!!!!!!!!}

\begin{abstract}
"A suprema felicidade da vida é a convicção de ser amado por aquilo que você é, ou, mais corretamente, de ser amado apesar daquilo que você é".
\end{abstract}

Victor Hugo 


\section{Agradecimentos}

Agradeço especialmente ao meu orientador, Prof. Dr. Geraldo Aleixo da Silva Passos, por seu exemplo de profissionalismo, de seriedade, de dedicação e de comprometimento com aquilo que faz. Por acreditar e confiar que sou capaz... A amizade sincera e toda a orientação foram imprescindíveis para a realização deste trabalho e meu conseqüente crescimento profissional. Acreditando que posso ficar, mesmo sem sua palavra "final", vou continuar... Obrigada Chefe!!!

À Professora Dra. Elza Sakamoto-Hojo e Dr. Catarina Satie Takahashi, pela colaboração e amizade, que auxiliaram no andamento da pesquisa.

Ao Professor Eduardo A. Donadi pelo apoio ao longo deste trabalho.

Aos amigos do laboratório de Citogenética e Mutagênese, pelo carinho e disponibilidade em todas as vezes que precisei utilizar o laboratório.

Ao Stephano, pela amizade e contribuição importantíssima nas análises estatísticas realizadas neste trabalho, até o último momento... Obrigada!!!!

Aos docentes, pós-graduandos e funcionários do Departamento de Genética da Faculdade de Medicina de Ribeirão Preto (FMRP) por toda a dedicação concedida nestes anos.

Às secretárias, Maria Aparecida, Suzie e Cleuza por toda a atenção e carinho.

Ao Departamento de Genética da Faculdade de Medicina de Ribeirão Preto (FMRP), em particular, ao Laboratório de Imunogenética Molecular, onde foi realizado este trabalho.

Aos meus grandes amigos do grupo de Imunogenética Molecular (de todas as épocas, inclusive os "visitantes"), pela convivência extremamente agradável, pelos ensinamentos, colaborações e pelas alegrias que marcaram estes anos, e em especial a Cristina por todo apoio, dedicação e incentivo desde o início... Adoro vocês!!!!

Aos meus amigos da $36^{\text {a }}$. Turma de Biologia, em especial ao meu eterno grupo, por toda amizade e alegria compartilhada mesmo depois de formados....Valeu!!!

Aos meus amigos de infância que me acompanham até hoje nesta caminhada, por toda amizade e apoio. Amizade é tudo na vida......Obrigada !!!!

Ao Laboratório TAGC INSERM de Marseille, França, onde foi realizado parte deste trabalho. 


\section{Remerciements spéciaux}

Moi même et mon directeur de thèse, le Professeur Geraldo Passos, nous voudrions remercier vivement toute l'Équipe de recherche «Technologies Avancées pour le Génome et la Clinique»(TAGC) URM 206 de l'Institut National de la Santé et de la Recherche Médicale (INSERM) de Marseille, France en particulier les Docteurs Catherine Nguyen et Denis Puthier par l'accueil au sein de cette Équipe et par l'orientation scientifique en ce qui concerne la dissection moléculaire du thymus.

Je voudrais aussi remercier Geneviève Victorero, Beatrice Loriod et Nicolas Boulanger par toute aide et amitié accordées.

Finalement nous sommes très reconnaissants aux Instituitions brésiliennes et françaises suivantes; Université de São Paulo, FAPESP, CNPq, INSERM et Université de Marseille, Campus de Luminy.

Je vous en remercie!

Danielle Magalhães 
"A ciência humana de maneira nenhuma nega a existência de Deus. Quando considero quantas e quão maravilhosas coisas o homem compreende, pesquisa e consegue realizar, então reconheço claramente que o espírito humano é obra de Deus, e a mais notável."

Galileu Galilei 


\section{RESUMO}

O timo é um órgão complexo estruturado por um estroma, o qual é formado principalmente por células epiteliais corticais (cTECs) e por células epiteliais medulares (mTECs) além de outros tipos celulares como células dendríticas (DC), macrófagos, linfócitos $\mathrm{B}$ e fibroblastos. Além disso, os precursores das células $\mathrm{T}$ originados da medula óssea chegam ao timo (timócitos) se maturando em linfócitos $\mathrm{T}$, os quais migram para a periferia. $\mathrm{O}$ timo é, portanto, o local de eventos muito importantes durante a maturação do sistema imune, incluindo o controle de sua própria homeostase.

No presente estudo, procuramos retratar as principais características do timo por meio da análise da expressão gênica em grande escala, isto é, descrevendo parte de seu transcriptoma. Fizemos uso da tecnologia dos cDNA microarrays em duas versões. Na primeira delas utilizamos cDNA microarrays construídos em lâminas de vidro e sondas fluorescentes marcadas com fluorocromos Cy3 ou Cy5 e, na segunda versão utilizamos cDNA microarrays em membranas de náilon e sondas radioativas marcadas com o isótopo ${ }^{33} \mathrm{P}$.

Para a análise dos dados, utilizamos programas de bioinformática dedicados, tais como o SAM (Significance analysis of microarrays) e o Cluster e TreeView.

Três conjuntos de resultados foram possíveis. No primeiro conjunto observamos a ocorrência da expressão gênica promíscua (PGE) de antígenos de tecidos/órgãos parenquimatosos (TSAs), demarcando sua emergência temporal durante a ontogenia do timo murino, a qual é influenciada pelo background genético das linhagens isogênicas estudadas. A ocorrência da PGE no timo é associada às bases genético-moleculares da indução de tolerância imunológica nas células $\mathrm{T}$, contribuindo com a prevenção da auto-imunidade. $\mathrm{O}$ segundo conjunto de resultados consistiu na análise da expressão gênica do timo de camundongos nocautes $(\mathrm{KO})$ envolvendo genes importantes para a maturação 
das células T, tais como TCR $\alpha$, LAT, Rel-b, RAG-1 e CD3 $\varepsilon$, possibilitando a observação de seus efeitos na regulação da transcrição neste órgão. Finalmente, o terceiro conjunto consistiu na definição da dissecação molecular virtual do timo. Por meio de perfis de expressão gênica particulares exibidos por cada tipo principal que povoa o timo, foi possível dissecar este órgão usando a tecnologia dos cDNA microarrays. 


\section{ABSTRACT}

The thymus is a complex organ structured by a stroma, which is formed mainly by cortical epithelial cells (cTECs) and medullary epithelial cells (mTECs) besides of other cell types such as dendritic cells (DC), macrophages, B lymphocytes and fibroblasts. Moreover, the $\mathrm{T}$ cell precursors arising from the bone marrow reach the thymus (thymocytes) maturing in $\mathrm{T}$ lymphocytes, which migrate to the periphery. Thus, the thymus is the place of very important events during the maturation of the immune system, including the control of their own homeostasis.

In the present study, we search to picture the main characteristics of the thymus by means of the large scale gene expression analysis that is, describing part of their transcriptome. We made use of the cDNA microarray technology in two versions. In the first one we used cDNA microarrays constructed on glass slides and fluorescent probes labeled with the fluorochromes $\mathrm{Cy} 3$ or $\mathrm{Cy} 5$ and in the second version we used cDNA microarrays on nylon membranes and radioactive probes labeled with ${ }^{33} \mathrm{P}$ isotope.

To data analysis we used dedicated bioinformatics programs, such as SAM (significance analysis of microarrays) and Cluster-Tree View.

Three sets of results were possible. In the first set we observed the occurrence of the promiscuous gene expression (PGE) of parenchymal tissue/organ specific antigens (TSAs), demarking their temporal emergence during the murine thymus ontogeny, which is influenced by the genetic background of the inbred strains studied. The occurrence of PGE in the thymus is associated to the molecular-genetics basis of the immune tolerance of T cells, contributing with the prevention of autoimmunity. The second set of results consisted in the analysis of gene expression of thymus from knockout mice (KO) involving genes important for T cell maturation, such as TCR $\alpha$, LAT, Relb, RAG-1 and CD3e, allowing the observation of its effects on the transcription 
regulation in this organ. Finally, the third set consisted in the definition of the virtual molecular dissection of the thymus. By means of particular gene expression profiling featured by each main cell type populating the thymus, it was possible to dissect this organ using the cDNA microarray technology. 


\section{SUMÁRIO}

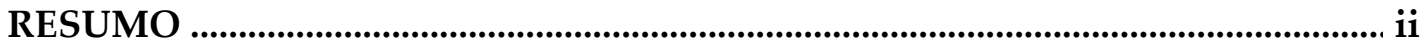

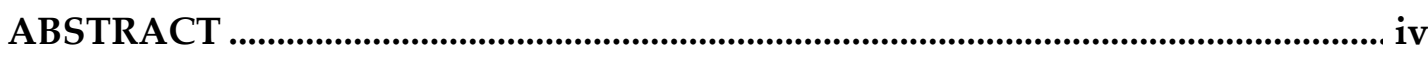

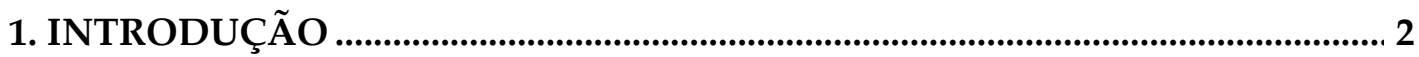

1.1 O papel do timo no desenvolvimento das células $T$ e na indução da tolerância imunológica.................................................................................................. 2

1.1.1 A formação do timo durante o desenvolvimento.................................................. 2

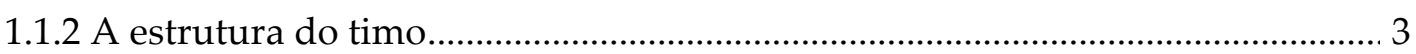

1.1.3 Migração dos timócitos da medula óssea para o timo …………………............... 6

1.1.4 Maturação dos timócitos em células T …............................................................... 7

1.1.5. Indução da tolerância imunológica ........................................................................ 14

1.1.6. A impotância dos camundongos nocautes (KO) ................................................... 15

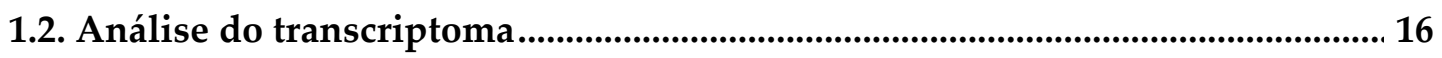

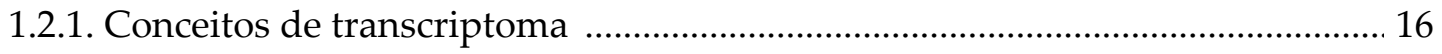

1.2.2.. Métodos de análise do transcriptoma ............................................................... 18

1.2.3. Expressão gênica promíscua (PGE) ………………………................................ 23

1.2.4. Microdissecção molecular virtual do timo .............................................................. 24

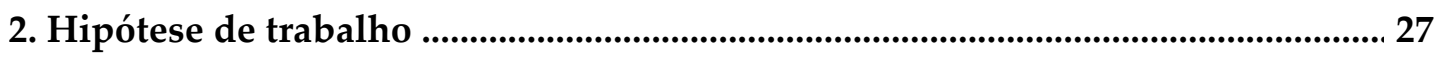

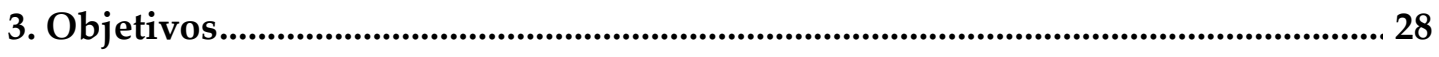

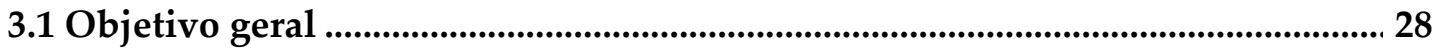

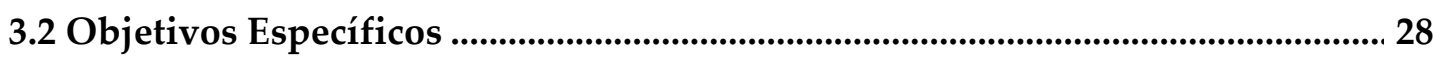

4. DELINEAMENTO EXPERIMENTAL ............................................................................. 30

4.1. Delineamento para análise da expressão promíscua de genes (PGE) no timo

4.2. Delineamento experimental para microdissecção virtual do timo por meio da análise do transcriptoma ................................................................................................... 31

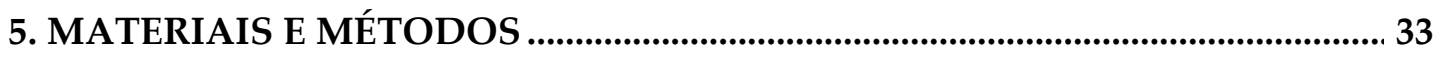

5.1. Linhagens isogênicas de camundongos ...................................................................... 33

5.2. Determinação da idade fetal ............................................................................................. 34

5.3.Remoção dos órgãos fetais.............................................................................................. 37 
5.5 Eletroforese de RNA total em gel denaturante ..................................................... 38

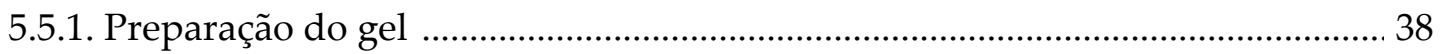

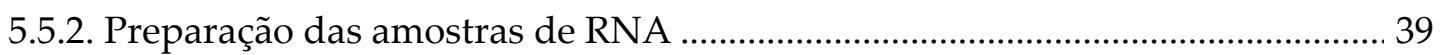

5.5.3. Pré-Hibridação e Hibridação Northern-blot ......................................................... 39

5.6. Eletroforese de RNA total utilizando a tecnologia Agilent .................................... 40

5.7. Preparação de cDNA microarrays em lâminas de vidro........................................ 42

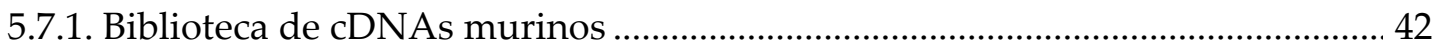

5.7.2. Amplificação de cDNA para a confecção de microarrays................................... 42

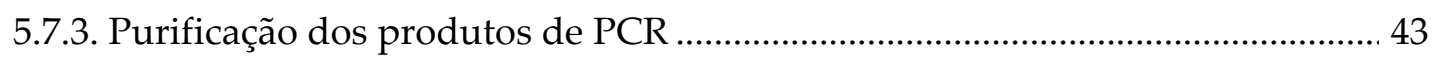

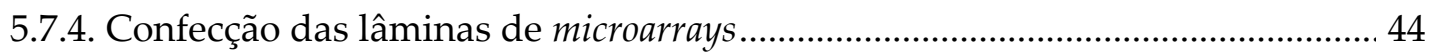

5.7.5. Delineamento das hibridações em microarrays.................................................... 45

5.7.6.Marcação das sondas complexas de cDNA com fluorocromos Cy3 e Cy5........ 48

5.7.7. Hibridação das lâminas de microarrays …………………………………................ 54

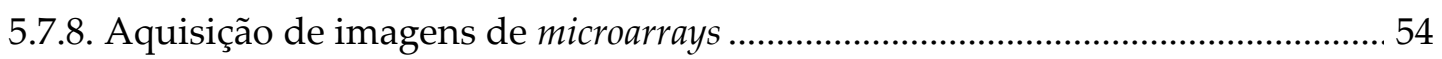

5.7.9. Quantificação e normalização dos dados de microarrays ...................................... 55

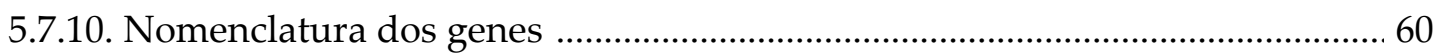

5.8. Preparação de cDNA microarrays em náilon.............................................................. 60

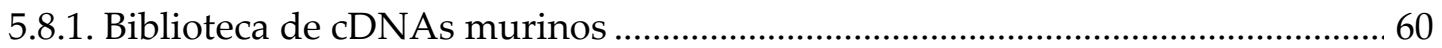

5.8.2. Amplificação de cDNA para a confecção de microarrays em náilon ................... 61

5.8.3. Detecção do padrão de pontos por hibridação com oligo-vetor ......................... 62

5.8.4. Preparação das sondas complexas a partir das amostras de RNA total ............ 63

5.8.5. Hibridação das sondas complexas de cDNA com os microarrays em náilon.... 65

5.8.6. Aquisição de imagens e processamento dos dados de microarrays ..................... 65

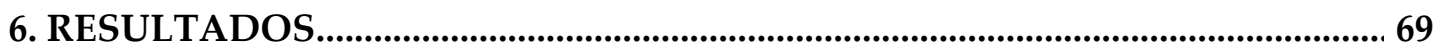

6.1. Características morfológicas no desenvolvimento fetal .......................................69

6.2. Análise da integridade das amostras de RNA .............................................................. 70

6.3. Confirmação da integridade do RNA por Northern-blot ..................................... 71

6.4. Confirmação da integridade do RNA total pela técnica Agilent (Lab-on-

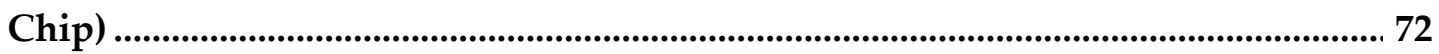

6.5. Amplificação dos clones de cDNA pela técnica de PCR ....................................... 73 
6.6. Determinação da expressão gênica promíscua (PGE) no timo

6.7. Determinação de assinaturas de expressão gênica dos tipos celulares encontrados no timo

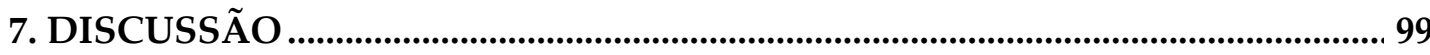

7.1. Expressão gênica promíscua no timo............................................................................. 99

7.2. Assinaturas de expressão gênica e microdissecção virtual molecular do timo 103

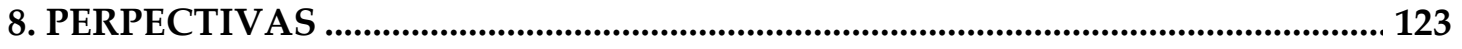

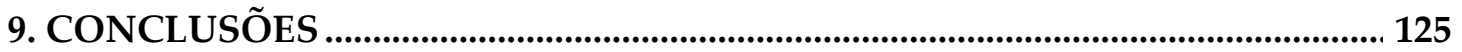

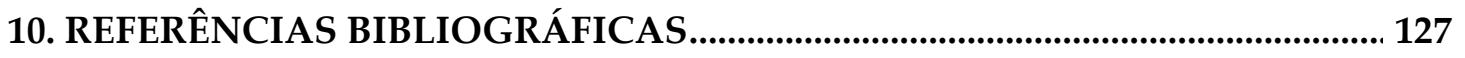

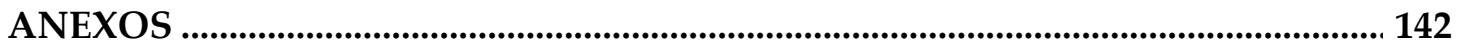

Anexo I - (Figura 28 - Imagens lâminas de vidro)......................................................... 144

Anexo I - (Figura 29 - Imagens das membranas de náilon) ........................................... 145

Anexo II - Tabela II - Genes do SAM...................................................................................... 147

Anexo III - Súmula curricular ........................................................................................... 164

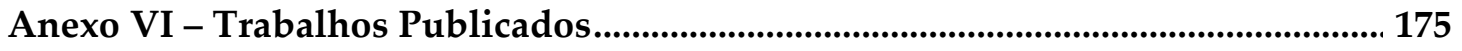




\section{ÍNDICE DE FIGURAS}

PÁGINA

FIGURA 1: Esquema representativo da estrutura do timo

4

FIGURA 2: Interações moleculares que acontecem entre timócitos em desenvolvimento e células epiteliais tímicas ................................................. 6

FIGURA 3: Estrutura e função do timo ............................................................................ 9

FIGURA 4: Recombinação e expressão do gene da cadeia $\alpha$ e $\beta$ do TCR …........................ 12

FIGURA 5: Ilustração dos métodos de marcação de sondas complexas de cDNA para microarrays.

FIGURA 6: Desenvolvimento dos membros anteriores e posteriores durante a gestação de camundongos.................................................................................. 36

FIGURA 7: Desenvolvimento dos órgãos do sentido (modificações externas) durante a gestação de camundongos 37

FIGURA 8: Chip miniaturizado "DNA LabChip" da Agilent Technologies. 41

FIGURA 9: Esquema dos principais tipos de delineamento experimental para

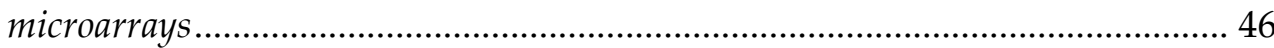

FIGURA 10: Delineamento dos experimentos com microarrays . 47

FIGURA 11: Preparação da fita simples de cDNA incorporada com amino alil com o kit "CyScribe Post Labelling"

FIGURA 12: Preparação do cDNA marcado com CyDye com o kit "CyScribe Post Labelling" 50

FIGURA 13: "Pipeline" utilizado na análise de dados de microarrays em lâminas de vidro

FIGURA 14: Gráfico de dispersão do programa SAM …………………............................ 59

FIGURA 15: "Pipeline" utilizado na análise de dados de microarrays em náilon .............. 66

FIGURA 16: Evolução das características morfológicas de fetos com idades de 13 a

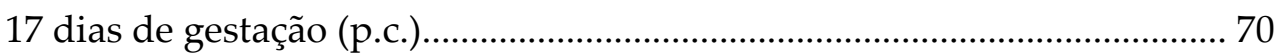

FIGURA 17: Eletroforese em gel de agarose 1,5\% mostrando o fracionamento das amostras de RNA total 
FIGURA18: Hibridação Northern-blot de amostras de RNA de órgãos fetais 71

FIGURA 19: Eletroforese pela tecnologia Agilent (Lab-on-Chip)

FIGURA 20: Representação gráfica da eficiência da amplificação por PCR dos clones de cDNA 74

FIGURA21: Avaliação das amplificações por PCR dos clones de cDNA 74

FIGURA 22: Genes diferencialmente expressos na relação timo - pool de órgãos de camundongos C57B1/6

FIGURA 23: Genes diferencialmente expressos na relação timo - pool de órgãos de camundongos híbridos (Balb-c x C57B1/6)F1............................................ 76

FIGURA 24: Número de genes induzidos ou reprimidos em timo fetal ........................... 77

FIGURA 25: Representação da expressão gênica específica de tecidos e órgãos em timo fetal. 79

FIGURA 26: Distribuição cromossômica dos genes reprimidos e induzidos no timo fetal 81

FIGURA 27: Agrupamento hierárquico baseado nos dados de expressão gênica 83

FIGURA 28: Identificação de assinaturas de expressão gênica 84

FIGURA 29: Imagens típicas de cDNA microarrays em lâminas 144

FIGURA 30: Imagens típicas de cDNA microarrays em náilon 145 


\section{ÍNDICE DE TABELAS}

PÁGINA

TABELA I: Descrição da morfologia dos fetos durante a evolução da gestação

TABELA II: Genes diferencialmente e significantemente induzidos em timo de

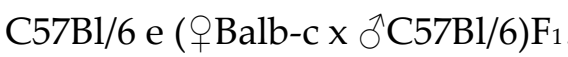

TABELA III: Genes com expressão diferencial que definem a assinatura de macrófagos.

TABELA IV: Genes com expressão diferencial que definem a assinatura de estroma tímico 88

TABELA V: Genes com expressão diferencial que definem a assinatura de timócitos .. 92

TABELA VI: Genes com expressão diferencial que definem a assinatura de timócitos imaturos. 96 


\section{Lista De AbReViaturas}

AA-dUTP: Aminoalil UTP

CD: Células dendríticas

$\mathrm{CD} 3 \varepsilon^{\circ}$ : nocaute homozigoto do gene CD3e

cDNA: DNA complementar

cTEC: Célula epitelial cortical tímica

Cy5: Cyanine -5

Cy3: Cyanine-3

DMSO: dimetil sulfóxido

DN: Timócito duplo negativo (Estágios 1 a 4)

DP: Timócito duplo positivo

E. coli: Escherichia coli

EST: "expressed sequence tags"

FDR: "False Discovery Rate"

$\mathrm{LAT}^{\circ}$ : nocaute homozigoto do gene Lat

MHC: Complexo Principal de Histocompatibilidade

MOPS: ácido propano sulfônico 3-(N-morfolino)

mTEC: Célula epitelial medular tímica

PCR: Reação de polimeriazação em cadeia

qsp: quantidade suficiente para

RAG1 ${ }^{\circ}$ : nocaute homozigoto do gene Rag-1

Relb $^{\circ}$ : nocaute homozigoto do gene Relb

RNAm: RNA mensageiro

RNAr: RNA ribossômico

RNAt: RNA transportador

SAM: "Significance Analysis of Microarrays"

SP: Timócito simples positivo 
S.O.U.R.C.E: "Stanford Online Universal Resource for Clones and ESTs" TCR: receptor de célula $\mathrm{T}$

$\mathrm{TCR} \alpha^{\circ}$ : nocaute homozigoto do gene TRA

TEC: Célula epitelial tímica

TR: Genes de receptores de célula T

TSA: Antígenos tecido-específicos

${ }^{33} \mathrm{P}$ : Isótopo radioativo fósforo 33

WT: will type ou tipo selvagem 
IINTCRR (O)ID)UI(Ç ÃO) 


\section{INTRODUÇÃO}

\subsection{O PAPEL DO TIMO NO DESENVOLVIMENTO DAS CÉLULAS T E NA INDUÇÃO DA TOLERÂNCIA IMUNOLÓGICA.}

\subsubsection{A FORMAÇÃO DO TIMO DURANTE O DESENVOLVIMENTO}

O timo deriva de invaginações do ectoderma no pescoço e tórax do embrião em desenvolvimento que formam estruturas chamadas de arcos branquiais (Abbas \& Lichtman 2005).

A hipótese de origem do timo que prevalece é a de "origem dual", a qual diz que forma-se um rudimento tímico de natureza reticuloepitelial e de origem endo-ectodérmica derivadas das terceiras bolsas faríngeas e fenda branquial. $\mathrm{O}$ retículo do epitélio medular tímico é de origem endodérmica, enquanto o retículo do epitélio cortical tímico de origem ectodérmica. Nesta bolsa se formam tubos de células epiteliais que vão crescendo em forma de cordões para baixo até o tórax. Os cordões perdem a comunicação com sua origem e se transformam na medula do timo. Durante sua migração, decorrente de sua aderência ao pericárdio visceral, o rudimento tímico é invadido por vasos sanguíneos que serão os portadores dos precursores de timócitos, células dendríticas, macrófagos e mastócitos. As células reticulares epiteliais emitem prolongamentos e formam os septos, corpúsculos de Hassal e as áreas onde vão ser ocupadas pelos linfócitos T em maturação no córtex. Posteriormente, iniciase a tração pelo pericárdio, que leva o timo até sua posição anatômica no mediastino anterior na maioria dos animais, sendo que o timo se mantém no extramediastino cervical nas aves e branquial nos peixes (van Ewijk et al. 2000; Gray et al. 2005).

Embora num primeiro momento estudos digam que o timo tenha se derivado das células epiteliais de ambas as origens endodérmica e ectodérmica, 
recentemente experimentos em aves e camundongos, via transplante ectópico, tem demonstrado conclusivamente que as células epiteliais tímicas são exclusivamente de origem endodérmica, deste modo, refutando o modelo de "origem dual" de ontogenia epitelial tímica e aceitando um novo modelo de “origem única" (Bartblott et al. 2006; Anderson \& Jenkinson 2001; Blackburn \& Manley 2004).

A involução alométrica do timo inicia-se pouco antes do nascimento e a involução absoluta ocorre na puberdade, entretanto o timo adulto continua a receber células precursoras, vindas da medula óssea e a lançar células colonizadoras das áreas T periféricas (Bodey et al. 1997).

\subsubsection{A ESTRUTURA DO TIMO}

O timo é um órgão linfóide primário em que os precursores de células T derivados da medula óssea se submetem a um processo complexo de maturação no contexto do microambiente tímico, representado por células não linfóides e linfóides e por componentes da matriz extracelular (ECM) (VillaVerde et al. 1995). É formado por dois lobos (direito e esquerdo), sendo ambos divididos em múltiplos lóbulos por septos fibrosos. Anatomicamente, cada lóbulo é dividido em uma região subcapsular, um córtex, que contém uma densa coleção de linfócitos T em maturação e uma medula, com uma população mais esparsa de linfócitos (tecido conjuntivo frouxo e células reticulares epiteliais), e onde ocorrem os processos finais de maturação dos linfócitos $\mathrm{T}$ (Abbas \& Lichtman 2005).

Cada um destes compartimentos forma um microambiente estromal especializado que é crucial para controlar a maturação das células T. Este estroma é composto essencialmente de células epiteliais corticais (cTECs) e medulares (mTECs), fibroblastos reticulares, células dendríticas e macrófagos derivados da medula óssea, além de estruturas conhecidas como corpúsculos 
de Hassal, localizados especificamente na medula tímica e composto de espirais compactas de células epiteliais remanescentes de células em degeneração (Abbas \& Lichtman 2005) (Figura 1).

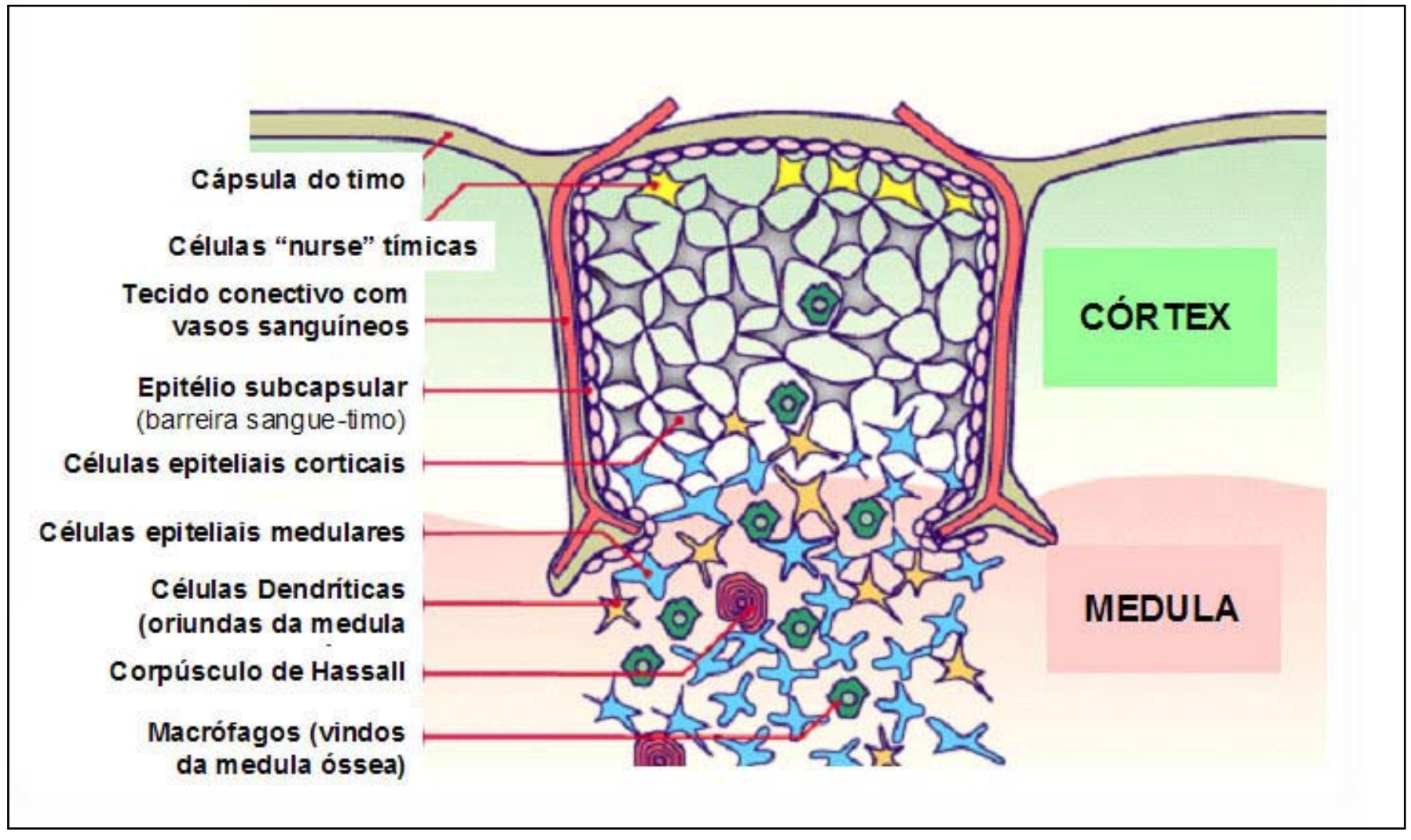

Figura 1. Esquema representativo da estrutura do timo, assim como de todos os componentes celulares que o povoam. [Modificado de www.embryology.ch].

A manutenção do microambiente tímico requer interações recíprocas entre timócitos e células estromais, denominadas de "cross talk" tímico (Gray et al. 2006). A Figura 2 ilustra algumas das interações moleculares que acontecem entre timócitos em desenvolvimento e células epiteliais tímicas.

As cTECs e mTECs produzem hormônios tímicos e citocinas, como as interleucinas (Il)-1, Il-3, Il-6, Il-7, Il-8 e fatores "stem cell", capazes de promover a maturação das células T. O estroma abriga também componentes da matriz 
extracelular essenciais para a célula T, ligantes de superfície celular e fatores solúveis (Abbas \& Lichtman 2005).

As células epiteliais tímicas são os componentes celulares principais do microambiente tímico, e influenciam diferentes aspectos da diferenciação dos timócitos, vias de interações célula-célula e das secreções de fatores solúveis, tais como os hormônios tímicos thymulin, thymopoietin, e thymosin- $\alpha 1$ (Savino 2006).

Algumas das células dendríticas encontradas no timo expressam marcadores celulares, como $\operatorname{CD} 8 \alpha$, que são encontrados tipicamente em linfócitos T, e são chamadas de células dendríticas linfóides para distingui-las das mielóides (Abbas \& Lichtman 2005).

Um complexo linfoepitelial localizado corticalmente no timo, as células "nurse" tímicas (TNC) são estruturas multicelulares linfoepiteliais formadas por uma célula epitelial tímica (TEC) que abriga 20-200 timócitos, carregando primeiramente o fenótipo duplo-positivo CD4/CD8, embora timócitos imaturos duplo negativos, bem como, células maduras simples positivas também possam ser encontradas. TNCs criam provavelmente um microambiente especial para a diferenciação e/ou proliferação dos timócitos, com timócitos sendo expostos aos antígenos do complexo principal de histocompatibilidade (MHC) e aos hormônios tímicos. Tal diferenciação ocorre em paralelo com a migração da célula dentro e fora do complexo (Savino 2006).

O mesênquima tímico, derivado da crista neural, também pode ser capaz de influenciar diretamente o desenvolvimento dos precursores de células $\mathrm{T}$ CD4-8, por apresentação de fatores de crescimento solúveis sobre componentes da matriz extracelular (ECM). Além de influenciar o desenvolvimento das células epiteliais tímicas imaturas, e assim ter um papel direto no estabelecimento do microambiente tímico (Jenkinson et al. 2003). 


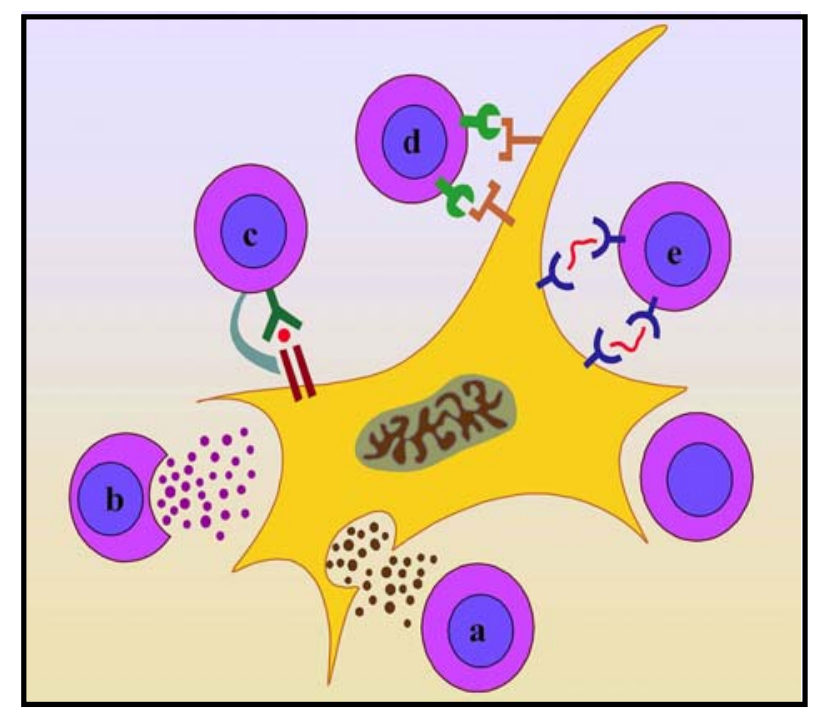

Figura 2. Número de interações moleculares que acontecem entre timócitos em desenvolvimento e células epiteliais tímicas. Onde (a) e (b) correspondem a interações mediadas por moléculas solúveis secretadas por células epiteliais (a) ou linfócitos (b), interações que envolvem um determinado peptídeo (ponto vermelho) sendo apresentado para MHC (expresso por células epiteliais) para o TCR e correspondendo a moléculas acessórias na superfície do timócito (c). A interação mostrada por (d) envolve moléculas de adesão e o respectivo co-receptor, e (e) descreve uma interação mediada por ligantes ECM e receptor. [Modificado de Savino 2006].

\subsubsection{MIGRAÇÃO DO TIMÓCITOS DA MEDULA ÓSSEA PARA O} TIMO

Durante o desenvolvimento fetal, ocorre a geração de todas as células sanguíneas, chamada de hematopoese, ocorre inicialmente em ilhotas sanguíneas do saco vitelino e do mesênquima paraaórtico e depois no fígado fetal que gera precursores de células T de origem mesodérmica, e no baço. Essa função é assumida de modo gradual pela medula óssea, principalmente dos ossos chatos, de forma que, ao atingir a puberdade, a hematopoese ocorre principalmente no esterno, nas vértebras, nos ilíacos e nas costelas (Abbas \& Lichtman 2005).

Os precursores de células T, ou células imaturas da linhagem de células $\mathrm{T}$, derivados da medula óssea entram no timo na junção cortico-medular, e 
então migram à região subcapsular da glândula através dos vasos sanguíneos. O desenvolvimento começa no córtex e, conforme os timócitos vão evoluindo eles migram para a medula tímica, de forma que esta contém principalmente células T maduras. Desta por sua vez, deixam o timo e entram no sangue e nos tecidos linfóides periféricos (Abbas \& Lichtman 2005).

As células do microambiente tímico produzem dois grupos de moléculas, as quimiocinas, incluindo Cxcl12 (Chemokine (C-X-C motif) ligand 12), a qual preferencialmente atrai timócitos imaturos $\mathrm{CD} 4 \mathrm{CD} 8$ - e $\mathrm{CD} 4^{+} \mathrm{CD} 8^{+}$, e Ccl21 (Chemokine (C-C) ligand 21), que exerce quimioatração para timócitos simples positivos maduros, e as proteínas da matriz extracelular, visto que os timócitos em desenvolvimento expressam os receptores correspondentes. Além disso, embora as quimiocinas e a matriz extracelular possam dirigir a migração dos timócitos por si mesmo, uma função combinada para estas moléculas parece contribuir para os padrões de migração resultantes dos timócitos em seus vários estágios de diferenciação (Savino et al. 2003; 2006).

\subsubsection{MATURAÇÃO DOS TIMÓCITOS EM CÉLULAS T}

O processo de maturação dos linfócitos consiste numa complexa seqüência de eventos biológicos, compreendendo a proliferação das linhagens celulares precursoras, a expressão diferencial de proteínas de membrana, rearranjos gênicos do receptor de antígeno, a seleção do repertório de linfócitos maduros, e conseqüente morte celular programada dos linfócitos não selecionados e finalmente a migração celular. Durante cada um desses estágios, as células sofrem significativas mudanças celulares e genéticas (Savino et al. 2004; Abbas \& Lichtman 2005).

A interação entre células estromais e linfóides dentro do microambiente tímico é um fator crítico para formar a correta especificidade antigênica do repertório de células $\mathrm{T}$, assim como para capacitá-lo a responder à apresentação 
de antígenos estranhos pelas moléculas de MHC e não responder a antígenos próprios (Bartblott et al. 2006).

Timócitos em estágios diferentes do desenvolvimento ocupam domínios distintos espacialmente restritos no timo, indicando que a diferenciação ocorre concomitantemente com uma migração altamente ordenada. Precursores de células T entram no timo pela junção cortico-medular, migra progressivamente da zona subcapsular para o córtex, e deste migra para a medula posteriormente, sendo que ao final do processo de maturação, os linfócitos T maduros simples positivos saem do timo em direção a periferia (Figura 3) (Blackburn \& Manley 2004).

Os timócitos imaturos corticais recém-chegados ao timo contêm os genes de TRs na configuração germinativa e, portanto, ainda não expressam o TCR, CD3 as cadeias $\zeta$ e os co-receptores CD4 e CD8; essas células são chamadas de timócitos duplo-negativos (DN) e se submetem à múltiplos ciclos de proliferação e de progresso ao estágio duplo-negativo CD4-CD8- (DN), aproximadamente 5\% do total de timócitos (Ramialison et al. 2002), com discretos passos de maturação distinguidos pela expressão de marcadores de superfície celular CD44 ${ }^{\text {high }} C D 25-(D N 1), C D 44^{\text {high }} C D 25^{+}(\mathrm{DN} 2), C D 44^{\text {low }} C D 25^{+}$ (DN3), e CD44 ${ }^{\text {low } C D 25-~(D N 4) . ~ A s ~ p r o t e i ́ n a s ~ d o ~ c o m p l e x o ~ r e c o m b i n a s e ~(R a g-1 ~ e ~}$ Rag-2) são expressas pela primeira vez nesse estágio, e os rearranjos $V(D) J$ se iniciam. Também neste período, as células tornam-se dependentes das interações de Il-7 (Interleukin 7) /Il-7r (Interleukin 7 receptor) para proliferar e manter sua sobrevivência (Anderson et al. 2002). 


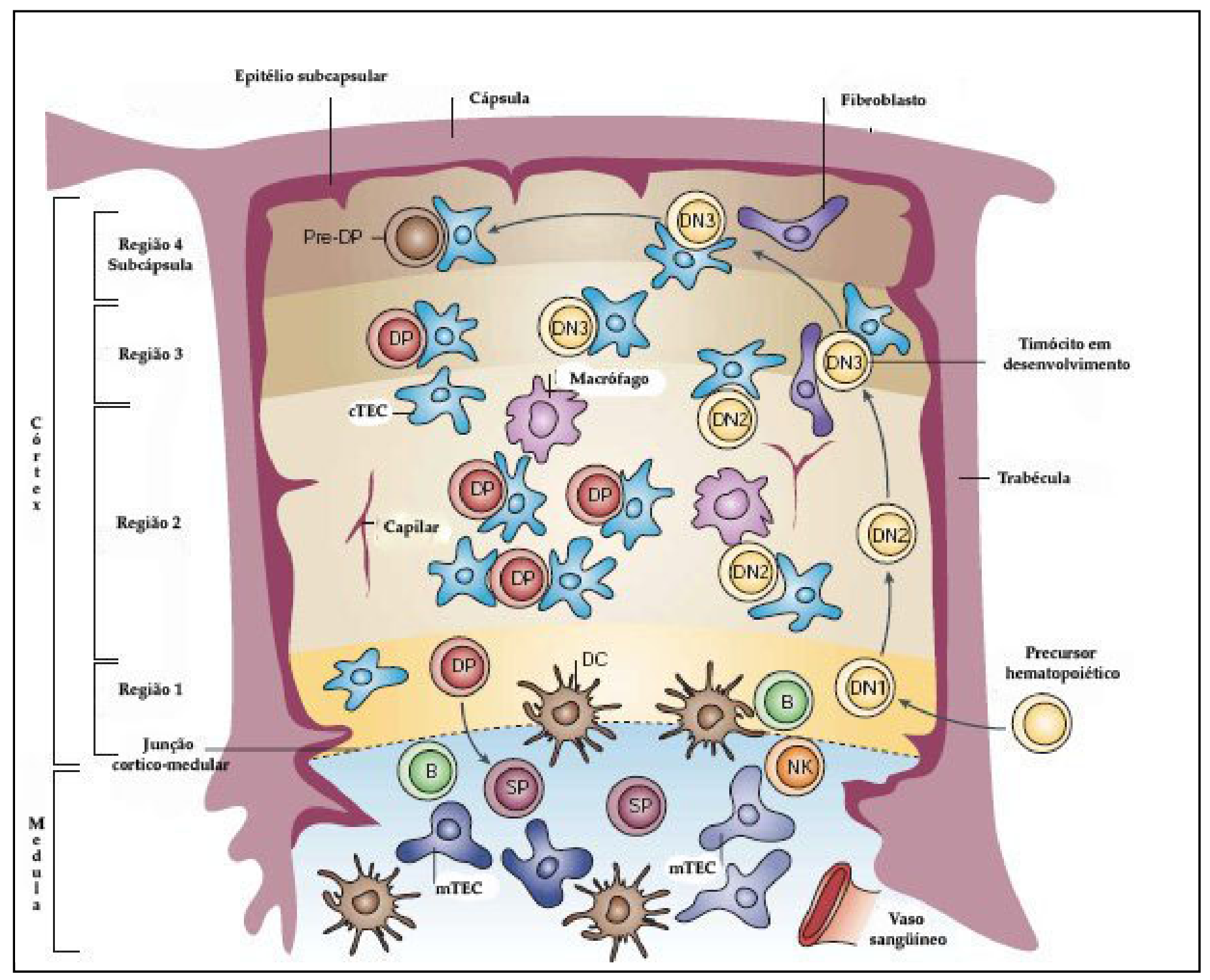

Figura 3. Estrutura e função do timo. Dividido em duas regiões, córtex e medula, povoados por diferentes subtipos celulares epiteliais tímicos (TECs). Nos adultos, os precursores de células T entram no timo pela junção cortico-medular, e começam então um programa altamente complexo de diferenciação, o qual está ligado à migração através do estroma tímico. Os subtipos diferentes de timócitos são encontrados conseqüentemente em regiões espacialmente restritas do timo. $\mathrm{O}$ córtex tímico foi separado em quatro regiões: Região 1, junção cortico-medular, local de entrada dos precursores de células T; Região 2, células diferenciadas em DN2 as quais se submetem a expansão clonal proliferativa; Região 3, inicia-se os rearranjos $\mathrm{V}(\mathrm{D}) \mathrm{J}$ dos genes TRs em células no estágio DN3; Região 4, transição de DN para o estado de DP (CD4+CD8+). Células DP migram do córtex para a medula tímica, onde se diferenciam em simples positivas (SP CD4+ ou CD8+). A seleção positiva ocorre no córtex entre as TECs corticais (cTECs), e a seleção negativa ocorre principalmente na medula, entre as TECs medulares (mTECs) e células dendríticas (DCs). Células SP que completaram o programa de diferenciação saem da medula tímica em direção a periferia. [Modificada de Blackburn \& Manley 2004]. 
Ainda nesta fase, tem-se a expressão do pré-TCR que emite sinais que estimulam a proliferação das células pré-T, a recombinação do lócus da cadeia $\alpha$, e a transição da fase de duplo-negativo para o estágio duplo-positivo, com iniciais níveis de expressão de CD3 (Abbas \& Lichtman 2005).

Durante a transição da fase $\mathrm{DN}$ para duplo-positiva $\mathrm{CD} 4^{+} \mathrm{CD} 8^{+}(\mathrm{DP})$, aproximadamente $85 \%$ dos timócitos (Ramialison et al. 2002) se redistribuem à região cortical. $\mathrm{O}$ rearranjo dos genes da cadeia $\alpha$ e a expressão do heterodímero TCR $\alpha \beta$ ocorrem na população $\mathrm{CD} 4^{+} \mathrm{CD} 8^{+}$, exatamente antes ou durante a migração dos timócitos do córtex para a medula. Além da expressão do TCR completo na superfície celular, nesta fase duplo positiva também ocorre a expressão de CD24 (CD24 antigen) e CD2 (CD2 antigen), moléculas de superfície dos linfócitos.

A recombinação $\mathrm{V}(\mathrm{D}) \mathrm{J}$ dos receptores de células T é um evento molecular essencial na maturação destas células. Os genes TCR em precursores de células $\mathrm{T}$ apresentam configuração germinativa não funcional, caracterizada por distanciamento entre os segmentos V, D, J, C no cromossomo. Durante a maturação da célula $T$, tais segmentos são rearranjados em uma seqüência definida, formando um gene TCR funcional, com os segmentos V, D, J justapostos, configurando os éxons de uma única região variável, através da reação de recombinação $\mathrm{V}(\mathrm{D}) \mathrm{J}$. A região constante é codificada por éxons separados que tipicamente se localizam na extremidade 3' dos segmentos gênicos que codificam a região variável. Além dos rearranjos ao nível do DNA na montagem de um gene, os éxons da região $C$, se unem aos éxons da região $V$, durante o processamento do RNA (Abbas \& Lichtman 2005).

A geração de grande diversidade nas regiões variáveis do receptor de antígeno de linfócitos T é crucial para que os organismos possam reconhecer e responder contra, virtualmente, todo e qualquer antígeno estranho. Esta diversidade é alcançada pela recombinação $\mathrm{V}(\mathrm{D}) \mathrm{J}$, um processo de 
recombinação sítio específica da molécula de DNA que só ocorre nos estágios inicias de desenvolvimento dos linfócitos T e B.

Genes funcionais de TRA e TRB são formados por rearranjos somáticos de segmentos gênicos da linhagem germinativa. A organização dos genes TRA e TRB é basicamente a mesma em todas as espécies estudadas. Cada locus TCR consiste de segmentos gênicos de regiões variáveis (V), joinig (J) e constante (C), e para as cadeias $\beta$ e $\delta$ incluem segmentos gênicos de diversidade (D).

De modo geral, o rearranjo dos segmentos gênicos, ocorre através da ligação de um segmento J a um dos segmentos D, formando uma união D-J, posteriormente um dos segmentos gênicos V se liga ao segmento D-J unidos. Toda seqüência de DNA interveniente aos segmentos gênicos que se ligaram passam por um processo de deleção (Paul, 1993). Os segmentos gênicos rearranjados são transcritos em um RNA primário, que se torna um RNA maduro após o seu processamento. O rearranjo D-J e V-DJ ocorre entre os segmentos gênicos da cadeia $\beta$ e $\delta$ de TCR; entre os segmentos gênicos da cadeia $\alpha$ e $\gamma$ onde não há segmentos $D$, ocorre apenas o rearranjo V-J (Abbas \& Lichtman 2005) (Figura 4).

Todo esse processo de recombinação é mediado por atividades coordenadas de várias enzimas, algumas das quais expressas exclusivamente em linfócitos imaturos, como Recombination activating gene (Rag-1 e Rag-2), e outras que são expressas de forma ubíqua, as enzimas de reparo de DNA. Este conjunto enzimático é chamado de recombinase $\mathrm{V}(\mathrm{D}) \mathrm{J}$ (Abbas \& Lichtman 2005). A recombinase $V(D) J$ atua após o reconhecimento das seqüências sinais de recombinação (RSS - Recombination signal sequences), que consistem de um heptâmero palindrômico e um nonâmero conservados separados por uma seqüência codificadora de 12 ou 23 pares de bases não conservados. A RSS está localizada a 3' de cada segmento $\mathrm{V}$, a 5' de cada segmento J e flanqueando ambos os lados do segmento D. O rearranjo só ocorre entre os segmentos gênicos que apresentam seqüências espaçadoras de comprimentos diferentes e RSS de orientação inversa (Abbas \& Lichtman 2005). 


\section{(A) Cadeia TCR $\beta$}

\section{(B) Cadeia TCR $\alpha$}

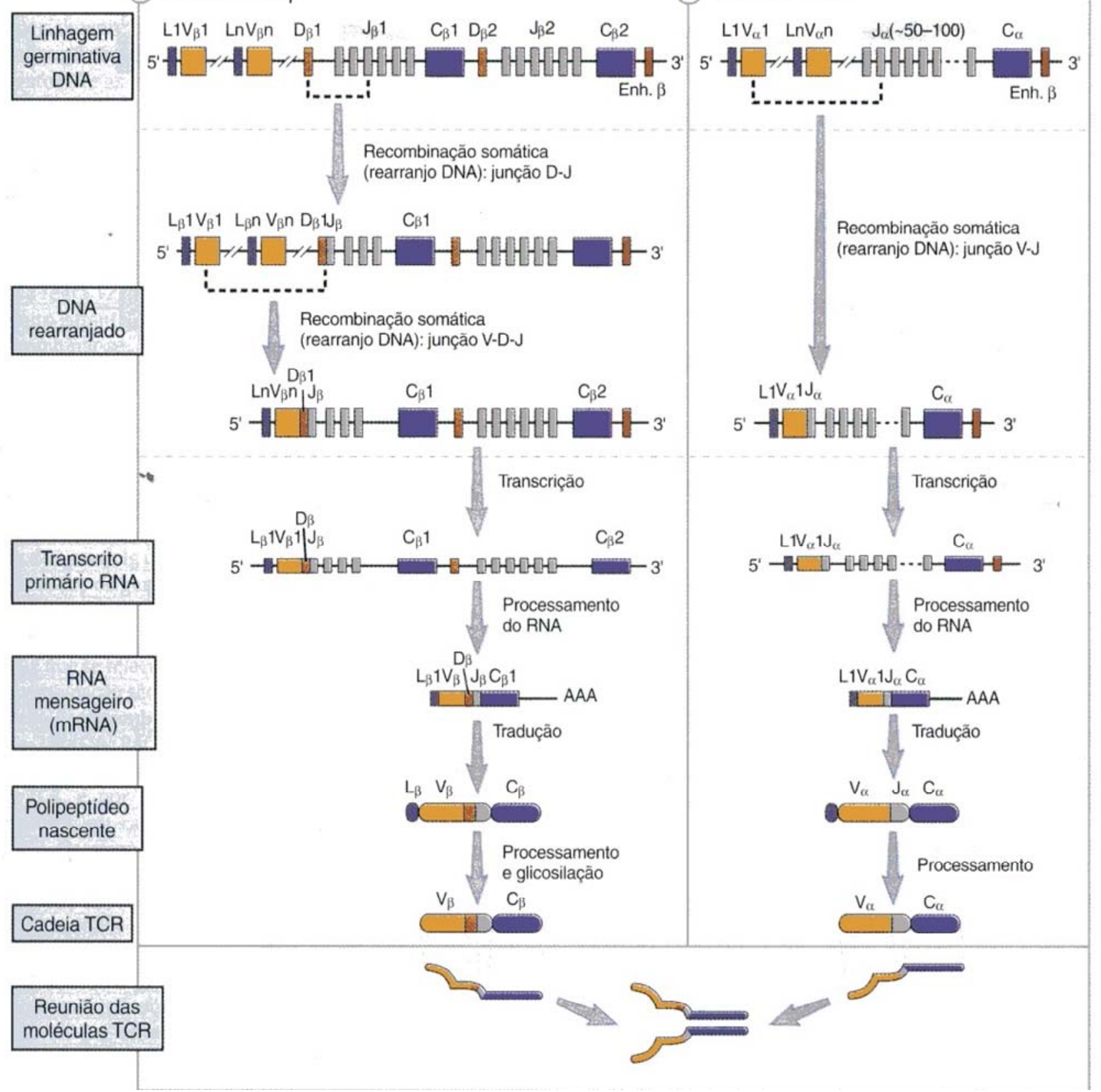

Figura 4: Recombinação e expressão do gene da cadeia $\alpha$ e $\beta$ do TCR. É mostrada a seqüência de eventos de recombinação e expressão de genes das cadeias TRB (A) e TRA (B)[modificado do Abbas \& Lichtman 2005]. 
Este rearranjo requer a atividade das enzimas linfóide-específicas, Rag-1 e Rag-2, que realizam a clivagem do DNA (van Gent et al. 1996); de uma endonuclease e um terminal deoxinucleotidil transferase, modificam as extremidades terminais antes da ligação (Candeias et al. 1996); e pelo menos 4 proteínas estão envolvidas no reparo do DNA, dentre elas a DNA-PK (Lewis 1994).

As primeiras células que expressam os TCRs estão no córtex tímico, e essa expressão é baixa em comparação com a célula $\mathrm{T}$ madura. Em virtude da expressão de seus complexos TCR completos, as células duplo-positivas podem responder ao antígeno e ficam sujeitas à seleção positiva e negativa. A maioria das células DP, as quais constituem cerca de $80 \%$ daquela população, morre por negligência, porque não reconhecem moléculas disponíveis de MHC expressas por células estromais tímicas (Savino 2006; Abbas \& Lichtman 2005; Kishimoto \& Sprent 1999).

As células que passam com sucesso pelos processos de seleção amadurecem em células T CD4+ ou CD8+ e são chamadas de timócitos simples positivos (SP), e compreendem aproximadamente 10\% dos timócitos no timo (Ramialison et al. 2002). Assim, os estágios de maturação das células $T$ podem ser rapidamente distinguidos pela análise da expressão das moléculas CD4 e CD8. Essa maturação fenotípica é acompanhada da maturação funcional (Abbas \& Lichtman 2005).

As células $\mathrm{CD}^{+}$adquirem a capacidade de produzir citocinas em resposta à subseqüente estimulação com o antígeno, expressam moléculas efetoras (como ligante de CD40) e auxiliam os linfócitos B e os macrófagos, enquanto as células CD8+ se tornam capazes de produzir moléculas que podem lisar outras células (Abbas \& Lichtman 2005).

Finalmente, os timócitos maduros com positividade única (células T CD4 e CD8 restritas ao $\mathrm{MHC}$ ) entram na medula do timo e deixam esse órgão pelos vasos sanguíneos para colonizar os tecidos linfóides periféricos (Haks et al. 1998). Apenas $10 \%$ dos timócitos que vivem no timo nesta fase vão formar a 
maioria do repertório de células T periféricas (Kishimoto \& Sprent, 1999; Grendler et al. 1997; Savino 2006).

\subsubsection{INDUÇÃO DE TOLERÂNCIA IMUNOLÓGICA}

A tolerância imunológica aos antígenos próprios envolve processos de seleção negativa e positiva de linfócitos T que se desenvolvem no timo, fenômeno também chamado de “educação tímica dos linfócitos T”(Abbas \& Lichtman 2005).

Células $\mathrm{T}$ imaturas provenientes da medula óssea passam pelo processo de maturação intratímica constituído pelos estágios de duplo-negativas (CD4CD8-), duplo-positivas $\left(\mathrm{CD}^{+} \mathrm{CD}^{+}\right)$e simples positivas $\left(\mathrm{CD}^{+}\right.$ou $\left.\mathrm{CD}^{+}\right)$. Durante estes estágios ocorre também a recombinação $\mathrm{V}(\mathrm{D}) \mathrm{J}$ dos $\mathrm{TCR} \alpha / \beta$. A tolerância imunológica, por sua vez, depende de interações entre TCR dos timócitos e o complexo peptídeo MHC próprio das células estromais tímicas (Anderson et al. 2006).

Timócitos duplo positivos que se submetem a seleção positiva no córtex tímico tem baixos níveis de TCR na superfície celular, enquanto que ao contrário, os timócitos maduros simples positivos na medula têm altos níveis de TCR expressos na superfície celular. Esta diferença de expressão do TCR na superfície celular tem sido usada para explicar o modelo de avidez nos eventos de seleção dos linfócitos (Yang et al. 2005).

A seleção positiva é o processo no qual os timócitos DP (no córtex) que apresentam TCR completo na superfície, se ligam com baixa avidez (fracamente) ao complexo peptídeo MHC próprio e são estimulados a sobreviver. Os timócitos cujos receptores não reconhecem as moléculas de MHC próprias morrem por apoptose. Isso assegura que as células T maduras sejam restritas ao MHC próprio. Na seleção positiva também há restrição de moléculas de classe I ou de classe II do MHC com os subtipos de linfócitos T, assegurando que as células T CD8+ citotóxicas sejam específicas a peptídeos 
expostos pelas moléculas de MHC de classe I, enquanto que as células T CD4+ auxiliares ligam-se às moléculas de MHC de classe II associadas ao peptídeo (Anderson et al. 2006; Abbas \& Lichtman 2005). As moléculas CD4 e CD8 funcionam como co-receptores do TCR durante a seleção positiva e reconhecem as moléculas de MHC enquanto que o complexo TCR reconhece o complexo peptídeo MHC. Os sinais liberados pelo complexo TCR e os co-receptores funcionam simultaneamente no sentido de promover a sobrevivência dos timócitos (Abbas \& Lichtman 2005).

Em contraste, a seleção negativa é a eliminação por apoptose dos timócitos cujos TCRs ligam-se com avidez (fortemente) ao antígeno próprio apresentado pela molécula de MHC própria de células dendríticas ou de mTECs. A avidez do reconhecimento do antígeno depende da afinidade do TCR e da concentração do peptídeo que a célula T reconhece. Este processo elimina células $\mathrm{T}$ em desenvolvimento que são fortemente auto-reativas contra antígenos próprios ubíquos, que são os antígenos próprios expressos pelas mTECs, antígenos tecido-específicos (TSAs) (Abbas \& Lichtman 2005).

De fato, todos os grupos de células apresentadoras de antígenos (APCs), assim como as corticais tímicas (cTECs), medulares tímicas (mTECs), células dendríticas (DCs) e macrófagos tem suas funções na apresentação de grupos de peptídeos próprios, e especialização nas suas habilidades para suportar as seleções positiva e negativa, contribuindo para a diversidade do quadro de antígenos próprios no timo (Klein \& Kyewski 2000; Kyewski \& Derbinski 2004; (Anderson et al. 2006).

\subsubsection{A IMPORTÂNCIA DOS CAMUNDONGOS NOCAUTES (KO)}

O camundongo é considerado um organismo-modelo genético para o estudo de doenças e desenvolvimento de mamíferos. Com os avanços recentes no sequenciamento de seu genoma, há um interesse muito grande em trabalhar 
com genes murinos a fim de se obter resultados aplicáveis aos seres humanos.

A habilidade de se manipular o genoma do camundongo transformou profundamente a pesquisa biomédica. Durante a última década, as tecnologias de transgênese convencional e de gene nocaute (knockout) tornaram-se ferramentas experimentais fundamentais para modelar desordens genéticas, atribuindo funções aos genes, avaliando drogas e toxinas e sendo de grande ajuda para responder a perguntas fundamentais na pesquisa básica e aplicada. Além de tornar-se cada vez mais evidente a demanda crescente para modelos murinos mais sofisticados (Bockamp et al. 2002).

O desenvolvimento de camundongos geneticamente modificados tem conduzido à geração de inúmeros modelos de perturbações transcricionais importantes para o estudo de várias situações, a maioria deles exibindo bloqueios precisos no desenvolvimento e assim um desequilíbrio celular quantitativo (Fischer \& Malissen 1998).

A imunologia é uma das áreas que mais se beneficia da tecnologia dos nocautes (Mak et al. 2006), sendo que vários genes de importância para o desenvolvimento do sistema imune já tiveram suas respectivas funções atribuídas por meio deste método.

Vários fatores de transcrição necessários para o desenvolvimento das células $\mathrm{T}$ tiveram suas funções decifradas, mas nenhum deles se mostrou necessário e suficiente para tais células (Anderson et al. 2002).

Por isso é que o uso de modelos de perturbações genéticas para análises transcricionais ainda poderá nos fornecer evidências preciosas de genes intermediários da maturação das células T ainda não descritos.

\subsection{ANÁLISE DO TRANSCRIPTOMA}

\subsubsection{CONCEITO DE TRANSCRIPTOMA}

Uma célula se mantém graças a seus produtos gênicos para poder efetuar as 
diversas funções, incluindo produção de energia, biossíntese macromolecular, divisão, manutenção da arquitetura celular, respostas aos estímulos do meio e a diferenciação. As proteínas são os componentes de trabalho ativo da maquinaria celular, ao passo que o DNA armazena as informações sua a síntese a qual é mediada pelos respectivos RNAs mensageiro (RNAm).

Em analogia ao termo genoma o qual se refere ao conjunto de genes de uma determinada espécie, criou-se o termo transcriptoma para se referir ao conjunto de RNAs, ou seja, os transcritos de uma célula num dado momento de seu ciclo. Como são os RNAm os responsáveis pela codificação da síntese de proteínas e, portanto, os mais importantes no estudo da expressão do genoma, geralmente entende-se que o transcriptoma é o conjunto dos RNAm. Mas é oportuno lembrar que tanto os RNAs transportadores (RNAt) e os RNAs ribossômicos (RNAr) devem ser incluídos no conceito do transcriptoma apesar de não serem codificadores de proteínas.

Recentemente foram incluídos os microRNAs no conceito de transcriptoma por representarem uma classe distinta de RNAs que controlam a expressão gênica ao nível da síntese e/ou degradação dos RNAm (Sevignani et al. 2006).

Durante todo o processo de diferenciação celular e tecidual, um conjunto diversificado de proteínas é mobilizado como resultado da expressão diferencial dos respectivos genes. Portanto, podemos dizer que durante o desenvolvimento o primeiro ponto de controle molecular é a expressão gênica ao nível do conjunto de RNAm, definido como transcriptoma. Hoje sabemos que o transcriptoma das células e tecidos é reflexo da razão entre a biossíntese de RNAm (transcrição) e sua degradação, muitas vezes causada pelos microRNAs (Sevignani et al. 2006).

Além disso, o transcriptoma é variável entre os diferentes tipos de células, tecidos e órgãos de um dado indivíduo, sendo que as próprias condições fisiológicas normais, como as diferentes fases do ciclo celular, ou patológica, como por exemplo, infecções ou neoplasias, influenciam no 
chamado perfil do transcriptoma (Passos et al. 2000).

A comparação da expressão gênica por mensuração dos níveis de RNAm de células em condições normais e patológicas está resultando em diagnósticos por "fingerprints" o que poderá ajudar a identificar disfunções moleculares com maior precisão, para uma posterior intervenção terapêutica (Xiang \& Chen 2000).

\subsubsection{MÉTODOS DE ANÁLISE DO TRANSCRIPTOMA}

Cópias de RNAm na forma de DNA (DNA complementar ou simplesmente cDNA) clonadas em vetores plasmidiais de E.coli e o sequenciamento a partir da

extremidade 3'-OH, perfazendo $0,3 \mathrm{a1}, 5 \mathrm{~kb}$, confere ao que chamamos de "Expressed Sequence Tags" (ESTs) ou em português, Etiqueta de Seqüência Expressa. As ESTs proporcionaram um avanço significativo na decifração do genoma funcional humano, de camundongos e outros organismos.

Mais recentemente o Brasil deu uma contribuição importante no sequenciamento de cDNAs pela tecnologia das seqüências ORESTES (OpenReading Frame ETSs) (Dias Neto et al. 2000). Tais seqüências correspondem a porções mais internas em direção à extremidade 5'dos RNAm, o que fez os pesquisadores conhecerem mais sobre a estrutura do transcriptoma humano.

Um grande progresso tem ocorrido nos últimos anos na caracterização de clones de cDNA de humanos, camundongos e outros organismos-modelo. Os clones de cDNA e suas seqüências formam a base para a técnica de arranjos em membranas de alta densidade (microarrays) para a análise de expressão gênica em grande escala (Duggan et al. 1999; Lipshutz et al. 1999).

Várias técnicas para a análise do transcriptoma analisando expressão de mRNA são disponíveis atualmente, assim como SAGE (análise em série da expressão gênica). Entretanto, estes métodos possuem desvantagens, quando o objetivo é analisar expressão em grande escala. Porém, o problema apresentado por estas técnicas pode ser solucionado por meio da tecnologia de microarrays 
(van Hal et al. 2000; Jordan 1998; Passos et al. 2000; Sakamoto-Hojo et al. 2003).

A tecnologia dos cDNA-microarrays mostrou ser uma ferramenta poderosa e muito difundida nos estudos de expressão gênica com aplicações no estudo de vários organismos tanto em situações normais como patológicas (Whitney \& Becker 2001). Aliando-se a disponibilidade das bibliotecas de cDNA com a robótica de alta precisão na deposição de pequenas amostras em superfícies sólidas, tornouse possível a preparação dos arrays (arranjos) de clones de cDNA, produtos de PCR (reação de polimerização em cadeia) e oligonucleotídeos em membranas de nylon ou em lâminas de vidro (Passos et al. 2000).

Pelo conhecimento do perfil de expressão gênica, é possível responder importantes questões, tais como, quantos genes e quais suas intensidades de expressão estão envolvidos num determinado processo biológico. Além disso, reflete o perfil transcricional de milhares de genes em resposta a um estímulo farmacológico ou a uma resposta imune entre outros (Kurella et al. 2001).

As sondas utilizadas nas hibridações com os microarrays (sondas de cDNA derivadas das amostras de RNA em estudo) podem ser marcadas com radioatividade $\left({ }^{33} \mathrm{P}\right)$ quando utiliza-se como plataforma membranas de nylon ou com fluorocromos (Cy3 e Cy5) quando utiliza-se lâminas de vidro (Figura 5).

Apesar da utilização de sondas fluorescentes que permitiram a miniaturização dos arrays devido a sua ótima resolução, os microarrays que utilizam radioatividade $\left({ }^{33} \mathrm{P}\right)$ em membranas de nylon são apreciados como uma alternativa econômica da tecnologia de expressão de genes, além de ter a vantagem de ser construído rapidamente, e fornecerem resultados bastante precisos e reprodutíveis (Cox 2001; Honore et al. 2006).

Como definiu Jordan (1998), as seqüências de cDNA fixadas no microarray são chamadas de alvo e o RNA extraído das células (cDNAs marcados) chamado de sonda. E neste trabalho, seguiremos esta definição, mas sabemos que vários laboratórios definem as seqüências depositadas no array como sondas. 
(A) Método Fluorescente
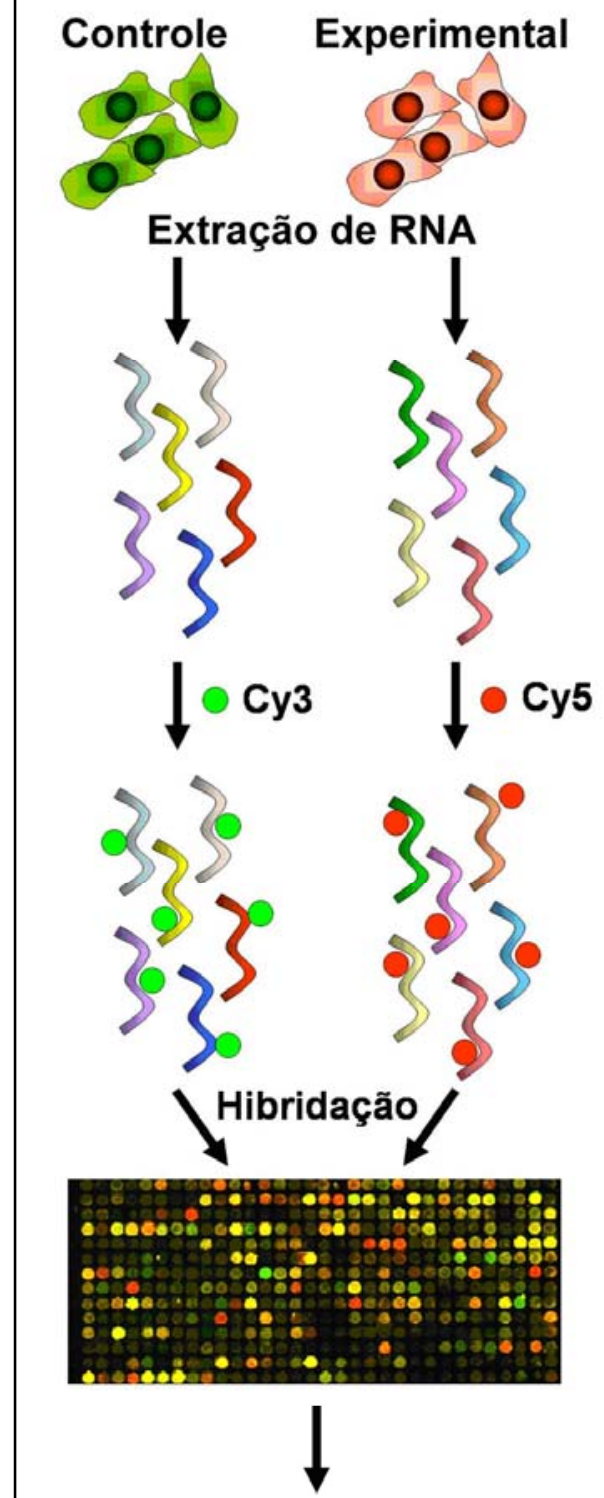

$\downarrow$ Cyз

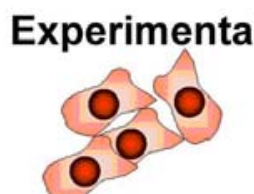

O

Análise dos dados
(B) Método Radioativo

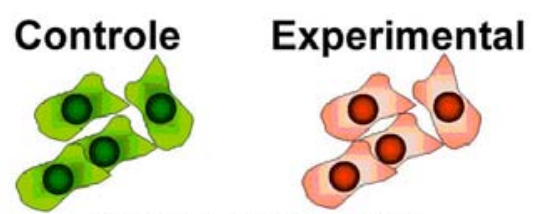

Extração de RNA
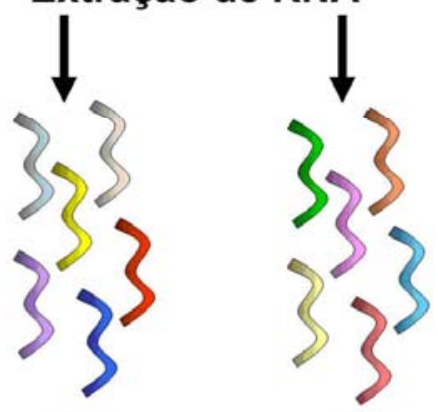

$\downarrow{ }^{33} \mathrm{P}$
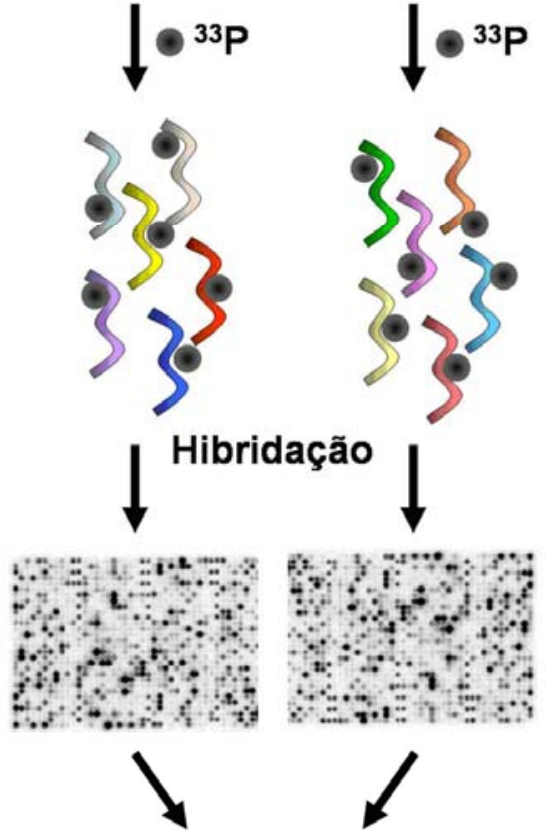

Análise dos dados

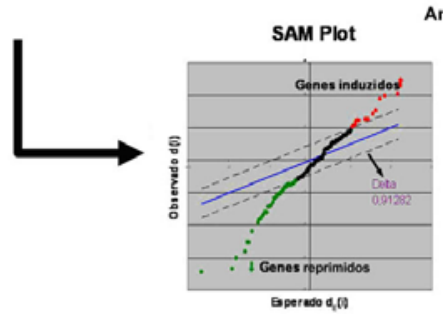

Análise por agrupamento

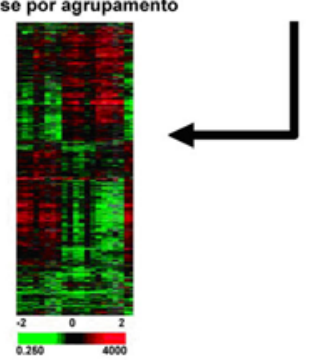

Figura 5. Ilustração dos métodos de marcação de sondas complexas de cDNA para microarrays. A) Método fluorescente usando Cy3 e Cy5 e lâmina de vidro e B) Método radioativo usando ${ }^{33} \mathrm{P}$ e membranas de náilon. [Modificada do livro Mutagênese Ambiental: Sakamoto-Hojo et al. 2003]. 
Nos últimos anos, nosso grupo de pesquisa tem se dedicado a estudos de genômica funcional aplicada à imunologia, campo que está sendo referida como imunogenômica. A base tecnológica é o emprego de cDNA microarrays no estudo de doenças auto-imunes como o lupus eritematoso sistêmcio humano (Pereira et al. 2004), do desenvolvimento ontogenético in vivo do timo de camundongos isogênicos (Espanhol et al. 2004; Magalhães et al. 2005) e do desenvolvimento do timo fetal em cultura (Cardoso et al. 2006a, 2006b).

No presente estudo além de utilizarmos a técnica de microarrays em nylon com 8750 seqüências de cDNA hibridadas com amostras marcadas com ${ }^{33} \mathrm{P}$, realizados no Laboratório INSERM TAGC/Marseille-França, também trabalhamos técnica de microarrays em lâminas de vidro com aproximadamente 4500 seqüências de cDNA hibridadas com amostras marcadas com fluorocromos Cy3 e Cy5 realizados em nosso laboratório na USP Ribeirão Preto.

Uma vez que os níveis de expressão são obtidos a procura por genes que possuam padrões semelhantes (genes co-expressos) constitui uma tarefa de grande interesse, pois existem evidências de que genes funcionalmente relacionados são co-expressos (Eisen et al. 1998; Spellman et al. 1998). A coexpressão também pode revelar outras informações, como por exemplo, alusões sobre o sistema regulatório dos genes em questão (Heyer et al. 1999).

O estudo em grande escala da expressão dos genes e suas redes regulatórias assim como suas interrelações requer que sejam desenvolvidas novas estratégias para lidar com a enorme quantidade de dados gerados. A necessidade de aplicativos computacionais específicos para a análise e interpretação de grande volume de dados obtidos é evidente. Assim, bancos de dados que disponibilizem conjuntamente dados de expressão e da funcionalidade gênica, bem como programas capazes de agrupar genes com perfis de expressão semelhantes, estão entre as soluções desenvolvidas pela bioinformática para a análise da grande quantidade de dados. 
Os dados sobre os níveis de expressão de milhares de genes necessitam ser analisados conjuntamente, mas sem que se perca a significância individual. Esse tipo de problema demonstra a necessidade de se empregar métodos estatísticos eficazes para a detecção das alterações com real significado biológico. Para isso são utilizados programas computacionais específicos para análise da expressão de genes em grande escala, que são: SAM (Significance Analysis of Microarrays) (Tusher et al. 2001) e o Cluster e TreeView (Eisen 1998).

Para efetuar a análise estatística dos dados gerados pelas lâminas de vidro, optou-se pelo programa SAM, desenvolvido pelo grupo de bioestatísitca da Universidade de Standford, que é um método adaptado especificamente para análise de dados de "microarrays" (Tusher et al. 2001).

Já para os dados gerados em membranas de náilon, utilizou-se o ambiente $\mathrm{R}$ para realizar as filtragens dos dados, assim como as normalizações e um tratamento estatístico. Após estes processos os dados foram agrupados por meio do programas Cluster e visualizados em forma de matriz de cores no programa Treeview (Eisen et al. 1998).

O programa $S A M$ nos mostra um conjunto de genes diferencialmente expressos (induzidos e reprimidos) na forma de um gráfico de dispersão (Figuras 21 e 22), já o programa Cluster-TreeView além de nos mostrar os genes diferenciais, constrói uma espécie de "mosaico" colorido (heat map) indicando a variação dos níveis de expressão do conjunto completo de genes analisados. $\mathrm{O}$ mesmo programa também constrói uma árvore de relacionamento (dendograma) onde faz o agrupamento hierárquico tanto das amostras como dos genes (Figura 27).

Neste estudo definimos as chamadas "assinaturas moleculares de expressão gênica" ou simplesmente "assinaturas de expressão" ou ainda "assinaturas de hibridação" dos diferentes tipos celulares que compõem o timo. 


\subsubsection{EXPRESSÃO GÊNICA PROMÍSCUA (PGE)}

Células $\mathrm{T}$ imaturas provenientes da medula óssea (timócitos) passam pelo processo de maturação intratímica passando pelos estágios de duplonegativas (CD4- $\mathrm{CD} 8)$, duplo-positivas $\left(\mathrm{CD} 4^{+} \mathrm{CD} 8^{+}\right)$e simples positivas $\left(\mathrm{CD} 4^{+}\right.$ ou $C D 8^{+}$). Durante estes estágios ocorre também a recombinação $\mathrm{V}(\mathrm{D}) \mathrm{J}$ dos receptores $\mathrm{TCR} \alpha / \beta$. A tolerância imunológica, por sua vez, depende de interações entre TCR específico e peptídeo MHC próprio. Como resultado, a diversidade de antígenos próprios que são acessíveis para o repertório nascente no timo determinará a extensão e especificidade da tolerância central ao próprio Depende, portanto, da expressão dos antígenos tecido-específicos (TSAs) (Kyewski \& Derbinski 2004).

Segundo Kyewski \& Derbinski (2004) assume-se que as células T periféricas toleram o reconhecimento de antígenos próprios. De acordo com isto, as células $\mathrm{T}$ regulatórias (Treg) são selecionadas no timo, mesmo que a ação destas células seja na periferia.

Entretanto, a expressão de antígenos específicos de tecidos (TSAs) no timo, que representa uma característica chave para efetuar a representação do próprio só foi reconhecida recentemente. A evidência da expressão de TSAs no timo de camundongos e de humanos foi referida como "expressão gênica promíscua" (PGE) (Derbinski et al. 2001; Gotter et al. 2004; Jolicoeur et al. 1994), o que reforçou a concepção de tolerância central de antígenos tecidos específicos.

Esta expressão promíscua de antígenos tecido/órgão-específicos ocorre tipicamente nas células mTECs, onde a expressão do gene Autoimmune regulator (Aire) assegura este importante fenômeno (Bartblott et al. 2006; Derbinski et al. 2005; Derbinski \& Kyewski 2005). O conjunto de genes expressos promiscuamente consiste de ontologia diversa, representando a maioria, se não todos os tecidos parenquimatosos (Kyewski \& Derbinski 2004). 
A implicação principal desta expressão heterogênea de genes no timo é associada com a manutenção da homeostase imunológica no corpo, controlando as reações autoimunes patogênicas. Assim, o desenvolvimento das células T no timo resulta na geração de um conjunto de células $\mathrm{T}$ tolerantes ao próprio capazes de reconhecer antígenos estranhos no contexto de moléculas de MHC próprias (Anderson et al. 2006).

Evidências iniciais para este fenômeno foram obtidas usando o método de transcrição reversa - PCR (RT-PCR), baseadas em antígenos de reações autoimunes, assim como insulina, receptor de acetilcolina ou proteína básica de mielina. Hoje isto é mais bem conhecido, o grupo de genes expressos é tão grande quanto possível, estimando-se de 5-10\% de todos os genes conhecidos no camundongo e no homem (Derbinski et al. 2001; Gotter et al. 2004; Kyewski \& Derbinski 2004).

A expressão gênica promíscua de TSAs no timo está causando impacto na re-interpretação da indução de tolerância central em linfócitos T.

\subsubsection{MICRODISSECÇÃO MOLECULAR VIRTUAL DO TIMO}

Com o sequenciamento sistemático de bibliotecas do cDNA e o advento das análises com microarrays, tornou-se possível descrever, a nível de tecido, o perfil de expressão de milhares de genes já conhecidos ou daqueles ainda não anotados. Como um exemplo, as análises de vários tecidos usando microarrays forneceram uma enorme fonte de informação e constituíram uma primeira etapa na descrição dos perfis da expressão gênica (Su et al. 2002 e Bono et al. 2003). Entretanto, no nível de cada órgão, uma definição mais elevada é necessária para especificar o "perfil de expressão histológico" dos genes individuais. Esta tarefa está atualmente em andamento, mas a produção de amostras informativas requer frequentemente procedimentos de microdissecção ou de purificação (Higgins et al. 2003). 
O timo é o principal local para a maturação dos linfócitos T. Embora as vias genético-moleculares envolvidas na ontogenia dos timócitos tenha sido assunto de vários estudos, alguns deles baseando-se na tecnologia dos microarrays (DeRyckere et al. 2003; Hoffmann et al. 2003; Schmitz et al. 2003; Puthier et al. 2004), nossa compreensão destes mecanismos é ainda fragmentada, e os resultados remanescentes são com freqüência difícil de situar numa visão integrada e dinâmica da maturação das células T e o "cross-talk" entre timócitos e células estromais (Puthier et al. 2004).

Existe uma vantagem no uso de camundongos geneticamente modificados em relação aos timócitos e populações estromais, pois a análise da expressão gênica do timo destes animais usando microarrays pode revelar assinaturas transcricionais características. E a identificação de tais assinaturas pode destacar a especialização funcional de cada população de células e deve permitir que se proponha um suposto papel para genes mal caracterizados. Além disso, a maturação das células $\mathrm{T}$ e o desenvolvimento estromal são eventos interdependentes, a análise combinada dos modelos de camundongos geneticamente modificados que afetam um ou ambos os compartimentos deve ainda ressaltar eventos importantes de "cross-talk" (Puthier et al. 2004).

Mais uma vez neste projeto conseguimos registrar e analisar "retratos" transcricionais do timo, desta vez analisando parte do transcriptoma $(>6000$ genes) de timos inteiros de camundongos nocautes (KO) envolvendo genes do sistema imune $\left(\operatorname{Rag}^{\circ}{ }, \mathrm{Lat}^{\circ}\right.$, e $\mathrm{CD}^{-} \varepsilon^{\Delta 5}\left(\mathrm{CD}^{\mathrm{a}} \mathrm{e}^{\circ}\right), \mathrm{TCR} \alpha^{\circ}$, e Relb $\left.{ }^{\circ}\right)$ comparados com timos inteiros de animais normais (WT) e também timócitos isolados.

Isto permitiu a identificação de assinaturas de expressão gênica características de populações celulares distintas do timo, tais como, dos timócitos, das células estromais e de macrófagos conseguindo assim, como chamou Puthier et al, 2004, uma "microdissecção molecular virtual". 
HUIIP(Ó) TIESIES IE (O)BB]IETIIIVOSS 


\section{HIPÓTESES DE TRABALHO}

I. A análise do trasnscriptoma durante o desenvolvimento ontogenético do timo nos permite a demarcação da emergência da expressão gênica promíscua (PGE).

II. A fusão de dados de microarrays (metanálise) obtidos a partir da análise da expressão gênica do timo de camundongos nocautes $(\mathrm{KO})$ de genes de timócitos com dados de microarrays de timo de fetos de camundongos normais nos possibilita, por comparação, a identificação do papel do gene nocauteado durante o desenvolvimento ontogenético. 


\section{OBJETIVOS}

3.1. OBJETIVO AMPLO: Analisar as assinaturas transcricionais características de timócitos e das populações estromais de timos de fetos de camundongos normais e camundongos nocautes adultos $(\mathrm{KO})$.

\section{2 . OBJETIVOS ESPECÍFICOS:}

I. Identificar assinaturas de expressão de genes específicos de tecidos que ocorre no timo e que definem expressão gênica promíscua (PGE).

II. Avaliar os níveis de expressão gênica diferencial, usando cDNA microarrays, de timo de camundongos nocautes adultos e de camundongos normais durante o desenvolvimento fetal, além das diferentes células isoladas do timo.

III. Comparar os resultados obtidos a fim de identificar possíveis modulações gênicas nos camundongos nocauteados e nos normais. 
DD) EILII NEAMMIENTC(O) IEXIPIEIRIIMIENTCAIL 


\section{DELINEAMENTO EXPERIMENTAL}

\subsection{DELINEAMENTO PARA ANÁLISE DA EXPRESSÃO PROMÍSCUA DE GENES (PGE) NO TIMO}

TIMOS E OUTROS ÓRGÃOS DE BALB-c, C57BL/6 E HÍBRIDOS F1 NAS RESPECTIVAS IDADES DE INÍCIO DA RECOMBINAÇÃO V(D)J

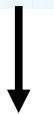

EXTRAÇÃO DE RNA TOTAL E ANÁLISE DA INTEGRIDADE POR NORTHERN-BLOT

PREPARAÇÃO DAS SONDAS COMPLEXAS DE cDNA MARCADAS COM FLUOROCROMOS CY3/CY5

HIBRIDAÇÃO DAS SONDAS FLUORESCENTES COM OS MICROARRAYS EM

LÂMINA DE VIDRO: 4500 SEQUÊNCIAS DA BIBLIOTECA MTB IMAGE

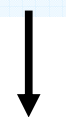

AQUISIÇÃO DAS IMAGENS, NORMALIZAÇÃO DOS DADOS, ANÁLISE ESTATİSTICA

DETERMINAÇÃO DA PGE USANDO O BANCO DE DADOS GNF SymAtlas (http://symatlas.gnf.org/SymAtlas/) 


\subsection{DELINEAMENTO EXPERIMENTAL PARA MICRODISSECÇÃO VIRTUAL DO TIMO POR MEIO DA ANÁLISE DO TRANSCRIPTOMA}

TIMOS DE CAMUNDONGOS C57BL/6 COM IDADES DE 14, 15, 16, 17 E 18 DIAS DE GESTAÇÃO (post coitum)

EXTRAÇÃO DE RNA E ANÁLISE DA INTEGRIDADE PELA TECNOLOGIA “LAB-ON-CHIP” AGILENT

PREPARAÇÃO DAS SONDAS COMPLEXAS DE cDNA MARCADAS COM RADIOISÓTOPO ${ }^{33} \mathrm{P}$

HIBRIDAÇÃO DAS SONDAS RADIOATIVAS COM OS MICROARRAYS EM NÁILON: 8750 SEQUÊNCIAS DA BIBLIOTECA MTB IMAGE

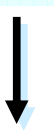

AQUISIÇÃO DAS IMAGENS, NORMALIZAÇÃO DOS DADOS, ANÁLISE ESTATÍSITCA E AGRUPAMENTO HIERÁRQUICO.

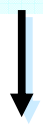

DEFINIÇÃO DAS ASSINATURAS DE HIBRIDAÇÃO ESPECÍFICAS 
MLATCIEIRILAL IE MIÉTCO)ID)OS 


\section{MATERIAL E MÉTODOS}

\subsection{LINHAGENS ISOGÊNICAS DE CAMUNDONGOS}

As matrizes das linhagens C57BL/6 e Balb-c foram adquiridas no Biotério do Departamento de Imunologia do Instituto de Ciências Biomédicas da USP.

As linhagens estão sendo mantidas por cruzamentos isogênicos em nosso laboratório e para acasalamento são mantidos juntos, quatro fêmeas e dois machos, tanto para as linhagens parentais como para obtenção dos híbridos.

Já as fêmeas prenhas da linhagem C57BL/6 utilizadas nos experimentos com microarrays em náilon no Laboratório TAGC INSERM de Marseille-França foram adquiridos no Biotério Charles River (França).

As fêmeas prenhas foram sacrificadas por deslocamento cervical, conforme normas do Comitê de Ética, e os fetos coletados por cirurgia do útero, e imersos em solução salina 0,9\% estéril em banho de gelo. Um dos fetos de cada ninhada foi fixado em formol $10 \%$ tamponado para posterior análise morfológica, e os outros foram utilizados para remoção cirúrgica do timo sob estereomicroscópio para posterior extração de RNA total.

Foram utilizadas 3 fêmeas de cada linhagem para cada uma das idades (triplicata amostral), sendo que cada amostra foi composta de um "pool" de timos e/ou outros órgãos de uma mesma ninhada (três ninhadas independentes).

Os camundongos nocautes utilizados nos experimentos com microarrays em náilon no Laboratório TAGC INSERM de Marseille-França foram abrigados em um local SPF (specific pathogen-free). Os camundongos C57BL/6 (tipo selvagem (WT)), $\mathrm{RAG1}^{\circ}$, e $\mathrm{TCR}^{\circ}$ foram obtidos do "Centre de Distribution, Typage et Archivage" (Orléans, France). CD3- $\varepsilon^{\Delta 5}\left(\mathrm{CD}^{\circ} \mathrm{e}^{\circ}\right), \mathrm{LAT}^{\circ}$, e os camundongos Relb $^{\circ}$ foram fornecidos pelos Drs. Maril Malissen e Philipe Naquet (Centre d'Immunologie de Marseille Luminy, Marseille, França). Os timos 
foram isolados dos camundongos adulto sacrificados entre 4 e 6 semanas de idade.

\subsection{DETERMINAÇÃO DA IDADE FETAL}

A análise morfológica dos fetos foi realizada durante a evolução da gestação, observando o desenvolvimento dos membros anteriores e posteriores, como também avaliando o surgimento dos órgãos dos sentidos (olhos e orelhas) e o comprimento dos fetos (cabeça-cauda). Segundo Rugh (1968), cada dia de gestação apresenta uma determinada característica que reflete a idade do feto, assim pode-se determinar a idade fetal com precisão. Além disso, o aparecimento do plug vaginal na manhã seguinte ao coito, foi indicativo do início da gestação, o qual foi marcado como dia zero.

\section{Características morfológicas de desenvolvimento dos fetos}

\section{Desenvolvimento dos membros}

As características dos membros, anteriores e posteriores de fetos de camundongos em cada dia gestacional e determinadas segundo Rugh (1968) estão descritas na Tabela I e mostradas na Figura 6. 
TABELA I. Descrição da morfologia dos fetos durante a evolução da gestação.

\begin{tabular}{|c|c|c|}
\hline Idade dos fetos (dias p.c.) & Membros Anteriores & Membros Posteriores \\
\hline 9 & $\begin{array}{l}\text { Membros como uma } \\
\text { pequena saliência. }\end{array}$ & \\
\hline 10 & Membros semicirculares. & $\begin{array}{l}\text { Membros como uma } \\
\text { pequena saliência. }\end{array}$ \\
\hline 11 & $\begin{array}{l}\text { Separação em patas e placas } \\
\text { circulares. }\end{array}$ & Membros semicirculares. \\
\hline 12 & Placas de forma pentagonal. & $\begin{array}{l}\text { Separação em patas e placas } \\
\text { circulares. }\end{array}$ \\
\hline 13 & Placas recortadas. & Placas de forma pentagonal. \\
\hline 14 & $\begin{array}{c}\text { Dígitos separados } \\
\text { distalmente, mas ainda } \\
\text { próximos à palma. }\end{array}$ & $\begin{array}{l}\text { Placas profundamente } \\
\text { recortada. }\end{array}$ \\
\hline 15 & \multicolumn{2}{|c|}{$\begin{array}{l}\text { Dígitos inteiramente separados e divergentes; extremidades } \\
\text { das falanges começam a aparecer. }\end{array}$} \\
\hline 16 & \multicolumn{2}{|c|}{$\begin{array}{c}\text { Dígitos } 2 \text { a } 5 \text { próximos e paralelos; extremidades das } \\
\text { falanges definidas. }\end{array}$} \\
\hline 17 & \multicolumn{2}{|c|}{$\begin{array}{l}\text { Dedos e pés completamente palmados como em recém- } \\
\text { nascidos. }\end{array}$} \\
\hline
\end{tabular}




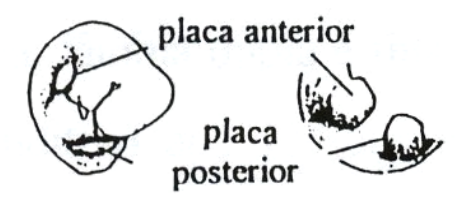

10 dias

11 dias

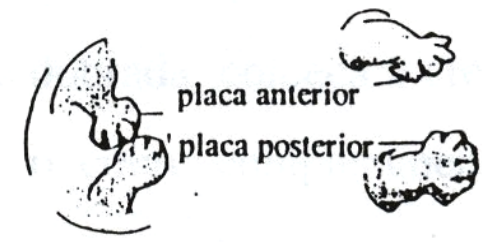

12 dias

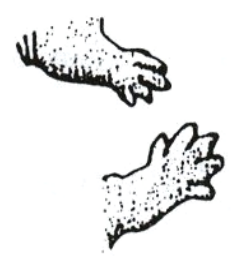

14 dias

membros antcriorcs

membros posteriores

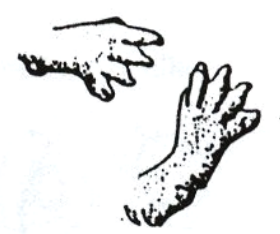

15 dias
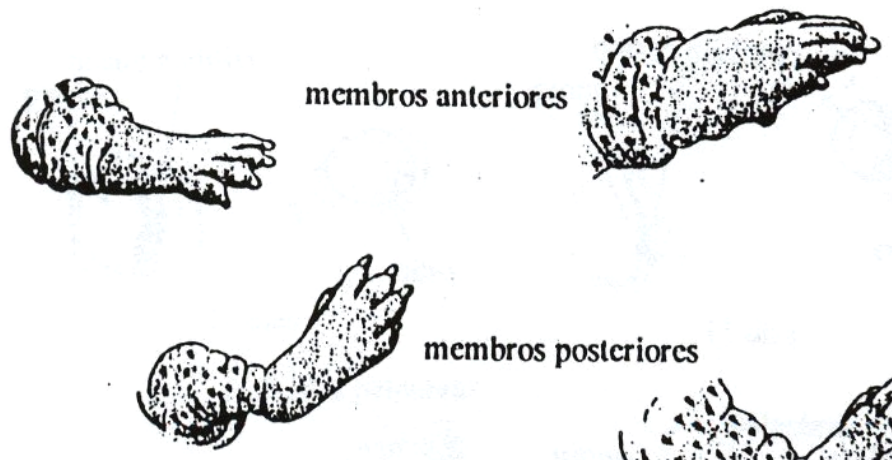

membros postcriores

16 dias

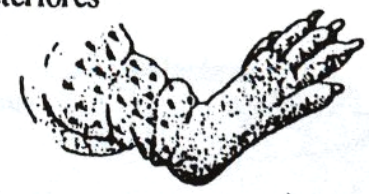

17 dias

Figura 6. Desenvolvimento dos membros anteriores e posteriores durante a gestação de camundongos (10 a 17 dias p.c.) (Rugh,1968).

* Desenvolvimento dos órgãos do sentido

As vesículas ópticas largas são aparentes aos 9 dias de gestação, e aos 12 dias os olhos são grandes e ovais. Durante os próximos 3 dias algumas partes dos olhos tornam-se visíveis através da córnea, que são temporariamente expostas, pois posteriormente são cobertas completamente pelas pálpebras que crescem até aos 16 dias. A pinna, lâmina dupla e fina de pele dobrada na região da orelha, começa a crescer em direção ao meato auditivo aos 13 dias e quase o cobre completamente aos 17 dias (Rugh, 1968). Estas características estão mostradas na Figura 7. 


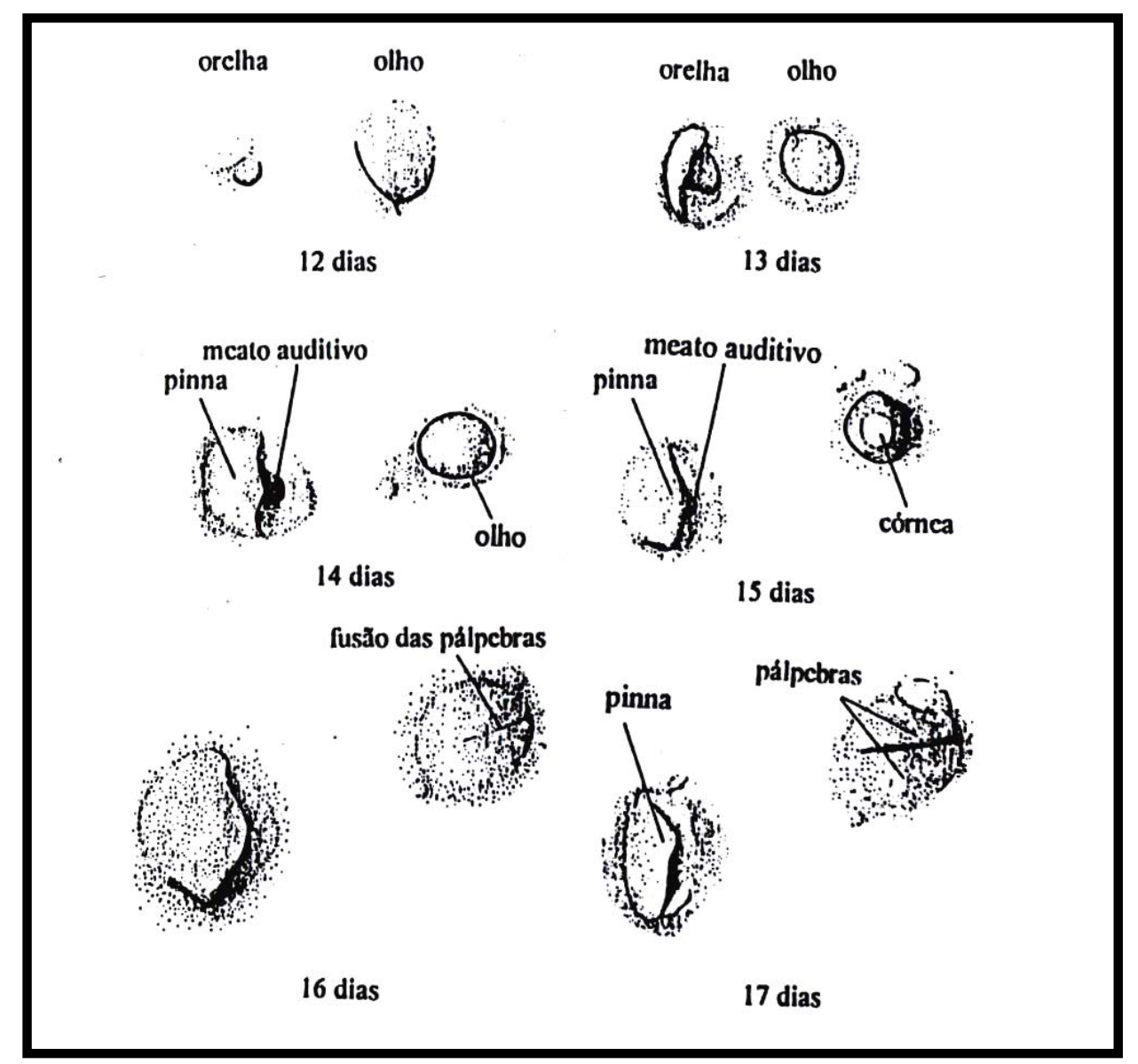

Figura 7. Desenvolvimento dos órgãos do sentido (modificações externas) durante a gestação de camundongos (12 a 17 dias p.c.) (Rugh,1968).

\subsection{REMOÇÃO DOS ÓRGÃOS FETAIS}

Os fetos foram dissecados, sob lupa estereoscópica abrindo a região abdominal até a região torácica, e então o esterno foi cortado expondo o timo, identificado pelos dois lobos característicos. Além disso, foi retirado o coração, fígado, pulmão, rim, intestino e cérebro, os quais foram imediatamente processados para extração de RNA total. 


\subsection{EXTRAÇÃO DE RNA TOTAL}

Para a extração do RNA total dos órgãos dos camundongos, utilizamos o reagente TRIZOL ${ }^{\circledR}$ (Invitrogen), seguindo as instruções do fabricante. Adicionase $200 \mu$ l de solução salina $0,9 \%$ estéril, e $1 \mathrm{ml}$ de Trizol ${ }^{\circledR}$, sendo que o volume de tecido não pode ultrapassar $10 \%$ do volume de Trizol $\circledast$. O tecido foi homogeneizado com auxílio de um micro homogeneizador tipo Potter.

Utilizamos preparações livres de proteína $\left(\mathrm{A}_{260} / \mathrm{A}_{280} \approx 2,0\right)$ e livres de fenol $\left(\mathrm{A}_{260} / \mathrm{A}_{230} \approx 2,0\right)$. A integridade das espécies de RNA foi avaliada por eletroforese em gel de agarose corada com brometo de etídeo, seguida de northern-blot, utilizando o oligo-sonda que reconhece o RNAr 28 S.

\subsection{ELETROFORESE DE RNA TOTAL EM GEL DENATURANTE (SAMBROOK et al., 1989)}

\subsubsection{PREPARAÇÃO DO GEL}

A agarose $(70 \mathrm{ml})$ foi fundida em água Milli-Q autoclavada $(1,5 \%$ de agarose), e quando à temperatura de $60^{\circ} \mathrm{C}$, é adicionado $20 \mathrm{ml}$ de formaldeído (37\%) e $22 \mathrm{ml}$ de tampão de migração 5X concentrado (20,6 g de MOPS [ácido propano sulfônico 3-(N-morfolino)], dissolvidos em $800 \mathrm{ml}$ de acetato de sódio 50mM, pH 7,0 ajustado com $\mathrm{NaOH}$ 2N e adicionados $10 \mathrm{ml}$ de EDTA 0,5 M pH $8,0$, volume final ajustado para $1000 \mathrm{ml})$. O gel foi solidificado em suporte de acrílico que foi, inicialmente, tratado com $\mathrm{NaOH} 0,5 \mathrm{M}$ por 10 minutos, assim como a cuba e o pente para eliminação de RNAase sendo posteriormente lavado com água Milli-Q autoclavada. 


\subsubsection{PREPARAÇÃO DAS AMOSTRAS DE RNA}

Em um tubo tipo Eppendorf novo e autoclavado colocado em banho de gelo foram adicionados 4,5 $\mu$ l de uma solução de RNA (5 $\mu$ g de RNA), $2 \mu$ le tampão de migração (5X); 3,5 $\mu$ l de formaldeído (37\%) e $10 \mu \mathrm{l}$ de formamida. A solução é, então, incubada à $65^{\circ} \mathrm{C}$ por 15 minutos, sendo posteriormente resfriado imediatamente em banho de gelo. Foi adicionado tampão de aplicação (1/10 do volume) e, as amostras aplicadas no gel. A eletroforese foi realizada à $80 \mathrm{~V}$ por cerca de 2,5 a 3 horas. Para o cálculo do peso molecular dos RNAs utilizamos RNAs ribossômicos $28 \mathrm{~S}(4,8 \mathrm{~Kb})$ e $18 \mathrm{~S}(1,9 \mathrm{~Kb})$ como marcadores.

A fim de prevenir a contaminação por ribonucleases no isolamento e manuseio do RNA, a vidraria, espátulas, pinças e "pulgas magnéticas" utilizadas foram autoclavadas; e todo material plástico, além de serem novos, foram autoclavados para o manuseio que foi realizado com luvas de látex sem talco.

\subsubsection{PRÉ-HIBRIDAÇÃO E HIBRIDAÇÃO NORTHERN-BLOT}

Após a eletroforese, os RNAs fracionados no gel foram transferidos para membrana de náilon (Hybond $\mathrm{N}+$ GE Healthcare) à vácuo, como já descrito no item 3.6, utilizando-se a solução de transferência $(\mathrm{NaOH} 50 \mathrm{mM})$, por cerca de uma hora e meia e fixados à $80^{\circ} \mathrm{C}$ por 15 minutos.

A membrana foi colocada em tubo de hibridação, contendo cerca de $10 \mathrm{ml}$ de solução de pré-hibridação (5X SSC; 5X Denhart 50X: Ficoll-400 10 g/L, polivinilpirrolidone $10 \mathrm{~g} / \mathrm{L}$; soro albumina bovina (BSA) fração V $10 \mathrm{~g} / \mathrm{L}$; 0,5\% SDS) e solução de DNA de esperma de salmão (10 $\mathrm{mg} / \mathrm{ml})$, seguindo a incubação em tubo em forno rolante (Hoefer) por 24 horas a $42^{\circ} \mathrm{C}$. A hibridação seguiu as mesmas condições de pré-hibridação, adicionando-se o oligonucleotídeo 28 S (5’ TGAATCCTCCGGGCGGACT 3') marcado com ${ }^{33} \mathrm{P}$. 
A marcação do oligonucleotídeo RNAr 28 S procedeu-se por incorporação do radioisótopo $\left[\gamma^{3}{ }^{33} \mathrm{P}\right]$ ATP (GE Healthcare). A mistura da reação de quinação consistiu de $1 \mu \mathrm{l}$ de oligonucleotídeo $(1 \mu \mathrm{g} / \mu \mathrm{l}), 1 \mu \mathrm{l}$ da enzima T4 polinucleotideo quinase $(10 \mathrm{U} / \mu \mathrm{l})$ (Invitrogen), $2 \mu \mathrm{l}$ de tampão quinase [10x] (fornecido pelo fabricante), $11 \mu$ l de água, $3 \mu \mathrm{l}$ de $\gamma^{33} \mathrm{P}$. Seguiu-se de incubação por $45 \mathrm{~min}$ a $37^{\circ} \mathrm{C}$. Os isótopos não incorporados foram separados em coluna com Sephadex G-50 (GE Healthcare) compactado em seringa de 1ml. A sonda agora com volume final de $100 \mu \mathrm{l}$ foi colocada na coluna e centrifugada por 2 min a 400xg. Uma alíquota de 1,0 $\mu$ l (Tricarb $2100 \mathrm{TR}$ ) foi retirada para contagem de c.p.m. em aparelho de cintilação (Packard Instruments, USA). Um total de 200.000 c.p.m. de sonda por $\mathrm{ml}$ de tampão de hibridação foi adicionado para hibridação.

O oligonucleotídeo radioativo foi adicionado ao tubo de hibridação de um forno Hoefer contendo a membrana e hibridado por cerca de 24 horas a $42^{\circ} \mathrm{C}$. As lavagens das membranas foram feitas utilizando-se 2 X SSC / SDS 0,1\% por 10 min a temperatura ambiente mais um banho com a mesma solução por 10 min a $42^{\circ} \mathrm{C}$. A exposição da membrana foi feita em placas de sensibilidade no aparelho leitor de fósforo radioativo (Cyclone, Packard Instruments, USA).

\subsection{ELETROFORESE DE RNA TOTAL UTILIZANDO A TECNOLOGIA AGILENT}

A tecnologia Agilent foi escolhida devida sua alta sensibilidade, pois neste trabalho tivemos dificuldades na obtenção de grande quantidade de RNA. Usando a tecnologia Agilent, analisamos apenas 300 ng de RNA total avaliando sua integridade.

O procedimento foi realizado por meio do aparelho Bioanalyser $2100^{\circledR}$ (Agilent Technologies) seguindo o protocolo do fabricante. A técnica inclui a 
separação eletroforética das frações de RNA total num "chip" miniaturizado (Figura 8), no qual aplicamos 300 ngRNA/1 $\mu$ l.

Para a preparação do gel "Dye Mix" foi homogeneizado $400 \mu \mathrm{l}$ de matriz para gel de RNA, fornecido pelo kit, o qual previamente filtrado e centrifugado. Deste filtrado, retirou-se $130 \mu \mathrm{l}$ para misturar com $2 \mu \mathrm{l}$ de RNA Dye concentrado.

Posteriormente aplicou-se $9 \mu \mathrm{l}$ desta mistura no poço assinalado com a letra G e em seguida colocou-se o chip na estação "Chip Primming", a qual exerce uma pressão durante 30 segundos com o auxílio de uma seringa para que o gel se espalhe por toda superfície do chip. Logo após, colocou-se mais $9 \mu \mathrm{l}$ de Gel Dye nos outros dois poços assinalados com a letra G.

Antes de depositar $1 \mu \mathrm{l}$ das amostras de RNA nos respectivos 12 poços, colocou-se $5 \mu$ l de tampão (RNA 6000 Nano) em todos os poços do chip, incluindo o marcador de pesos moleculares (RNA 6000 ladder).Após a deposição das amostras, agitou-se o chip em um vortex durante 1 minuto, para remoção de possíveis bolhas formadas durante o procedimento.

É necessário estabilizar os eletrodos do equipamento antes de utilizá-lo. Assim, colocou-se no aparelho um chip específico com $350 \mu \mathrm{l}$ de "RNase Zap" (estabilizador) durante 1 minuto e em seguida outro chip com $350 \mu$ de água estéril durante 10 segundos. Este procedimento foi repetido três vezes.

Após a estabilização dos eletrodos, colocou-se o chip das amostras de RNA no aparelho, ajustaram-se todas as condições eletroforéticas com auxílio de um software dedicado, e a imagem da corrida das amostras foi observada cerca de 30 minutos após.

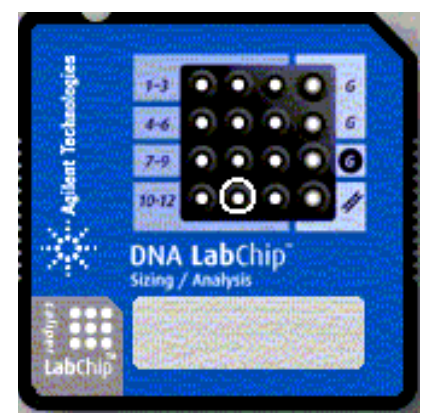

Figura 8. Chip miniaturizado "DNA LabChip" da Agilent Technologies. 


\subsection{PREPARAÇÃO DE cDNA MICROARRAYS EM LÂMINAS DE VIDRO}

\subsubsection{BIBLIOTECA DE CDNAS MURINOS}

Nosso laboratório mantém uma biblioteca de cDNA murino (Biblioteca MTB IMAGE), com cerca de 9.000 clones de timo provenientes do "IMAGE Consortium" (http://image.llnv.gov). São clones com seqüências "expressed sequence tags" (EST), cujos tamanhos moleculares variam de 500 a 1.500 pb, e está totalmente caracterizada, cujos clones estão seqüenciados e catalogados. Os clones estão identificados com seus respectivos "accession numbers" (Acc) no GenBank, Clone ID, o nome do gene e a posição de cada clone nas placas de 384 poços em planilhas do programa Excel ${ }^{\circledR}$ Microsoft. Conservamos esta biblioteca em E. coli em placas de microtitulação (384 poços) a $-80^{\circ} \mathrm{C}$ (material gentilmente cedido pela Dra. Catherine Nguyen, do INSERM-TAGC ERM 206, Marseille, França).

\subsubsection{AMPLIFICAÇÃO DE CDNA PARA A CONFECÇÃO DE} MICROARRAYS

Os clones de E. coli da biblioteca de cDNA IMAGE murina, repicados em placas de 384 poços contendo meio de cultura 2X LB + ampicilina foram incubados durante 16 horas, na proporção de $5 \mu$ da cultura original diluídos em $45 \mu \mathrm{l}$ de meio de cultura 2X LB (volume final em cada poço: $50 \mu \mathrm{l}$ ). A seguir uma alíquota de $8 \mu l$ da cultura foi transferida para outra placa de 384 poços, contendo $72 \mu \mathrm{l}$ de água deionizada estéril, e esta placa incubada a $95^{\circ} \mathrm{C}$ por 10 min. para lise das células. Após centrifugação a 4000xg por 5 min. foi retirado $10 \mu \mathrm{l}$ do sobrenadante e adicionado a $40 \mu \mathrm{l}$ de um mix para PCR contendo tampão da reação de PCR (10X), solução de dNTP $(2 \mathrm{mM})$, primers com seqüências consenso aos três vetores presentes na biblioteca $(10 \mu \mathrm{M})$, primer LBP 
(5'GGGTTGAATTAGCGGAACG3'), Taq Polimerase $(5 \mathrm{U} / \mu \mathrm{l})$ e água deionizada estéril q.s.p $50 \mu$ l. O programa para amplificação dos insertos teve como base aquele descrito por Menossi et al., 2000: 5 minutos a $94^{\circ} \mathrm{C}$, seguidos de 30 ciclos $\left(94^{\circ} \mathrm{C}\right.$, por 30 segundos; $55^{\circ} \mathrm{C}$ por 30 segundos, $72^{\circ} \mathrm{C}$ por 2 minutos), seguida por uma extensão final de 7 minutos a $72{ }^{\circ} \mathrm{C}$ e 5 minutos a $4{ }^{\circ} \mathrm{C}$. Foi realizada em um aparelho termociclador "Mastercycler Gradient" (Eppendorf), em placas de PCR seladas com adesivo laminado para evitar evaporação.

Cerca de 2 amplificações PCR de cada clone foram realizadas, sempre totalizando $50 \mu \mathrm{l}$ de volume.

A avaliação da qualidade dos produtos amplificados pela PCR foi feita em gel de agarose 1\%, em tampão TAE 1X (Tris-acetato 0,04 M, EDTA 0,001 M) contendo brometo de etídio $(10 \mathrm{mg} / \mathrm{ml})$ a $80 \mathrm{~V}$, durante $15 \mathrm{~min}$. A visualização das bandas foi realizada utilizando transluminador U.V. e fotografados em Polaroid.

\subsubsection{PURIFICAÇÃO DOS PRODUTOS DE PCR}

Para obtenção de uma eficiente fixação dos insertos de cDNA amplificados tanto nas membranas de náilon ou nas lâminas de vidro é necessária a remoção de nucleotídeos não incorporados e primers da reação de PCR (Hedge et al. 2000). Utilizamos a purificação dos produtos de PCR por precipitação com etanol.

Os produtos de PCR $(50 \mu \mathrm{l})$ foram transferidos para placas de cultivo com fundo em "U" e foram adicionados $10 \mu \mathrm{l}$ de acetato de sódio $3 \mathrm{M}$ pH 4,8 em cada poço de uma placa de 96 poços. Em seguida, os produtos das duas PCR foram agrupados, totalizando $100 \mu \mathrm{l}$, que foram transferidos para esta mesma placa. Após a adição de $100 \mu \mathrm{l}$ de etanol absoluto, as placas foram incubadas por 16 horas (overnight) a $-20^{\circ} \mathrm{C}$. Após este tempo, as placas foram centrifugadas 
a $4000 x g$ por $60 \mathrm{~min}$. a $2-8^{\circ} \mathrm{C}$. O sobrenadante foi desprezado e o pellet foi ressuspenso em $100 \mu \mathrm{l}$ de etanol 70\%. As placas foram novamente centrifugadas a $4000 x g$ por $30 \mathrm{~min}$ a $2-8^{\circ} \mathrm{C}$. O sobrenadante foi novamente desprezado e a placa secou à temperatura ambiente overnight. Após a placa seca, o pellet foi ressuspenso em $50 \mu$ l de água deionizada autoclavada.

Uma alíquota de $5 \mu$ l destes produtos foi aplicada em gel de agarose $1 \%$ contendo brometo de etídeo, visualizado em transluminador U.V. e fotografado em Polaroid para avaliar a qualidade dos produtos amplificados.

As placas foram secas em forno a $42^{\circ} \mathrm{C}$ e adicionou-se $27 \mu$ de solução de espotagem (DMSO 50\% - dimetil sulfóxido) por poço da placa. Em seguida, estas placas foram levadas ao freezer $-20^{\circ} \mathrm{C}$ e os produtos foram congelados e descongelados por 3 vezes para uma melhor dissolução do DNA concentrado. Posteriormente, os clones foram passados para as placas do robô, e estocadas a $4^{\circ} \mathrm{C}$ até a deposição dos produtos de PCR em membranas de náilon Hybond $\mathrm{N}^{+}$ (GE Healthcare) ou em lâminas de vidro.

\subsubsection{CONFECÇÃO DAS LÂMINAS DE MICROARRAYS}

Amostras de produtos de PCR purificados foram preparadas para deposição em lâminas de vidro adicionando-se mesmo volume (1:1) de Reagente D (GE Healthcare) e transferidas para microplacas de 384 poços (Genetix). Por meio de um robô Array Spotter III (Amersham Molecular Dynamics) as amostras foram depositadas por um conjunto de 12 canetas que deposita um volume de 0,9 nl da amostra baseada na ação de capilaridade em superfície de lâminas de vidro (Corning ${ }^{\circledR}$ - UltraGaps 40015). Após a deposição de cada conjunto de amostras as canetas foram lavadas automaticamente em uma estação de lavagem que utiliza sucessivamente água purificada (18 megohm/cm), etanol absoluto (Merck), solução 0,2 $\mathrm{M}$ de $\mathrm{KOH}$ e água novamente. As canetas foram secas com nitrogênio 5.0 analítico antes das 
próximas amostras serem carregadas. A câmara de deposição das amostras em lâminas do robô Array Spotter III possui temperatura e umidade controladas. A umidade relativa de deposição das amostras foi de $\sim 55 \%$ e a temperatura foi de $\sim 25^{\circ} \mathrm{C}$. Além disso, este robô está instalado numa sala especial com ar limpo (sala limpa classe 10.000). Após a deposição e secagem de todas as amostras nas lâminas, o DNA foi fixado por "cross-linking" por meio de irradiação ultravioleta a $500 \mathrm{~mJ}$ de energia (Hoefer UV Crosslinker).

\subsubsection{DELINEAMENTO DAS HIBRIDAÇÕES EM MICROARRAYS}

Uma escolha chave em um projeto que envolve a tecnologia de microarray é utilizar comparações que podem ser diretas ou indiretas isto é, estabelecer comparações dentro ou entre as lâminas. Existem três principais tipos de delineamento: 1, inversão de corantes (dye-swap), 2, experimentos em volta (looping) e 3, RNA de referência (Figura 9). Mas, não existe um delineamento experimental ideal para todas as situações, ou seja, diferentes desenhos experimentais são necessários para contextos experimentais diferentes. Qualquer que seja o tipo de desenho utilizado será requerido o mesmo número de hibridações, e a decisão sobre o tipo de delineamento deve considerar a pergunta do trabalho. 


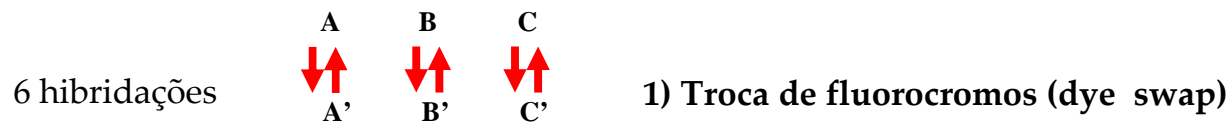

6 hibridações

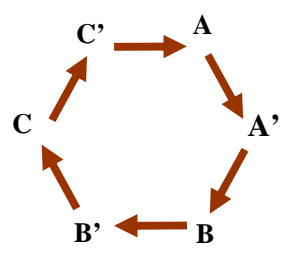

2) Experimentos em volta (looping)

6 hibridações

$$
\begin{array}{ccc}
\mathbf{A} & \mathbf{B} & \mathbf{C} \\
\mathbf{A} & \mathbf{A} & \mathbf{1} \\
\mathbf{R} & \mathbf{R} & \mathbf{R}
\end{array}
$$

3) Amostra de referência (RNA de referência)

$$
\begin{array}{lll}
\text { A }^{\prime} & \text { B' }^{\prime} & \text { C' }^{\prime} \\
\mathbf{A} & \mathbf{4} & \mathbf{1} \\
\mathbf{R} & \mathbf{R} & \mathbf{R}
\end{array}
$$

Figura 9. Esquema dos principais tipos de delineamento experimental para microarrays. A, B e C-amostras controle; $\mathrm{A}^{\prime}, \mathrm{B}^{\prime}$ e $\mathrm{C}^{\prime}$ - amostras teste; $\mathrm{R}$ - pool de RNA de referência.

O pool de RNA derivado de linhagens celulares é a amostra de referência mais utilizada atualmente. Para fornecer a cobertura ótima dos genes depositados na lâmina, as amostras de referência são freqüentemente constituídas de diferentes linhagens celulares oriundas de vários tecidos. Como neste trabalho escolheu-se o uso de RNA de referência, segue algumas considerações:

Ensaios de co-hibridação diferencial usando microarrays medem a expressão gênica relativa de amostras emparelhadas e de uma amostra referência, sendo que o poder da análise de microarray vem da identificação de padrões informativos de expressão de um gene através das experiências múltiplas. O cumprimento destes objetivos é facilitado usando uma amostra de referência comum para todos os experimentos que forneça uma medida da expressão base para cada gene, permitindo a normalização e a comparação de experimentos independentes. 
Um vasto número de linhagens celulares pode não melhorar necessariamente a representatividade total dos genes depositados no array, pois algumas linhagens celulares expressam significativamente mais genes do que outras e, nem todas as linhagens expressam todos os genes em níveis semelhantes. Misturar RNA de muitas linhagens celulares pode diluir os transcritos raros de modo que a sua representação no "pool" final do RNA corre o risco de ficar abaixo do limite detectável (Yang et al. 2002).

O delineamento das hibridações de microarrays consistiu em marcar tanto as amostras de timo fetal como as amostras de pool de órgãos fetais e com fluorocromo Cy5 e combiná-los numa mesma lâmina com amostras de RNA (cDNA) de referência marcados com Cy3 (Figura 10).
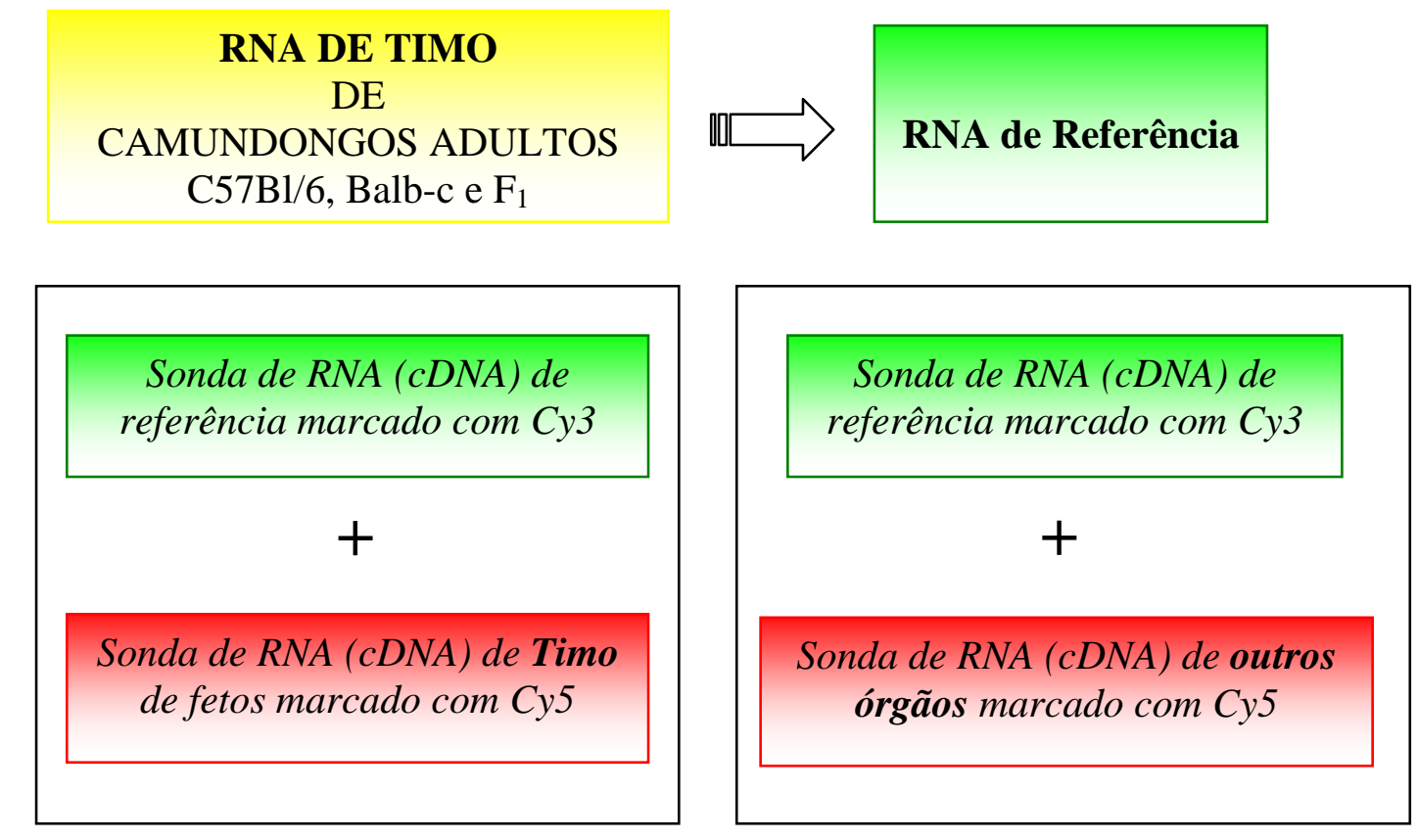

Figura 10. Delineamento dos experimentos com microarrays. Foi utilizado RNA total (cDNA total) de timo de camundongo adulto como RNA de referência (marcado com Cy3). As amostras tanto de timo experimental como dos outros órgãos fetais foram marcados com Cy5. 


\subsubsection{MARCAÇÃO DAS SONDAS COMPLEXAS DE CDNA COM} FLUOROCROMOS CY3 E CY5

Amostras de RNA foram convertidas a cDNA e marcadas utilizando o Kit CyScribe Post-Labelling (GE Healthcare) que envolve a preparação e adequação do cDNA em dois passos. No primeiro passo ocorre a síntese da primeira fita de cDNA com a incorporação de nucleotídeos amino- alil dUTP modificados, com posterior degradação da cadeia de RNAm e purificação do cDNA para remoção de nucleotídeos livres e oligômeros (Figura 11). No segundo passo, o cDNA é marcado com formas reativas de ésteres NHS Cy3 e Cy5 que se ligam aos nucleotídeos modificados e após um processo de purificação para eliminação dos $C y D y e$ não incorporados a sonda está pronta para hibridação (Figura 12). 
ANELAMENTO

\section{RNA Total}

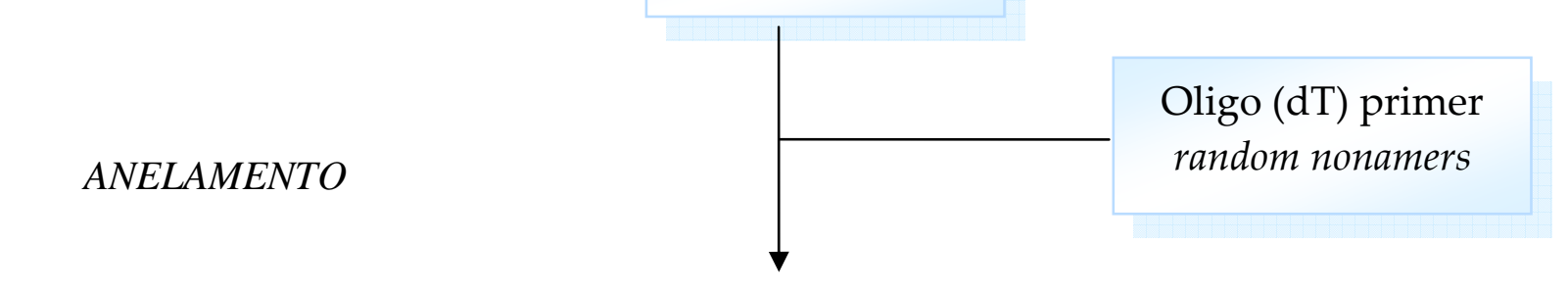

Anelamento do RNA

SÍNTESE DE cDNA

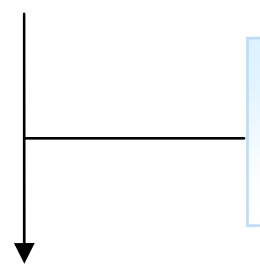

Nucleotídeos, AA-dUTP,

Tampão da Reação, Enzima

(Transcriptase Reversa)

Anelamento da fita simples de cDNA incorporada com amino alil (AA-dUTP) com o RNA

DEGRADAÇÃO DO RNAm

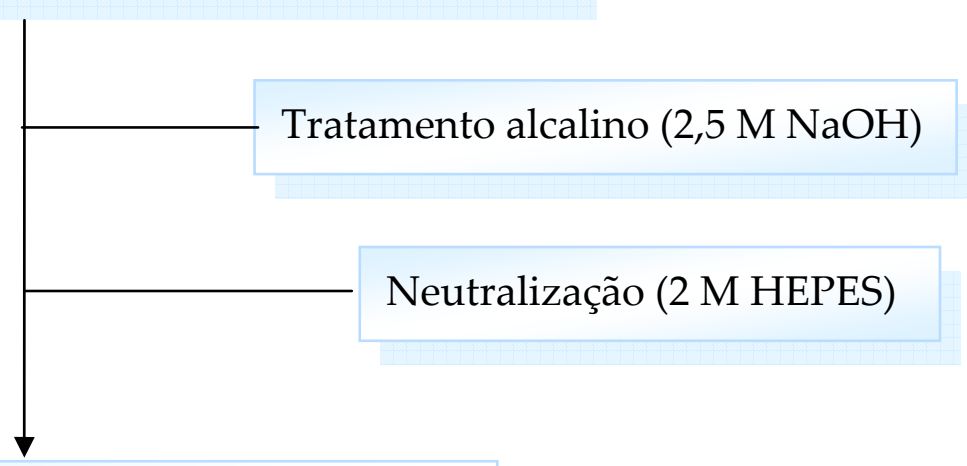

Fita simples de cDNA incorporada com amino

alil livre de nucleotídeos e oligômeros

PURIFICAÇÃO DO cDNA

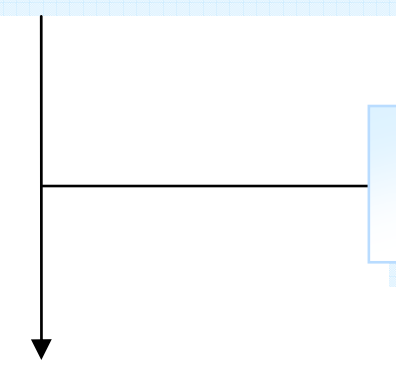

Purificação com colunas

CyScribe GFX

Fita Simples de cDNA marcada e incorporada com

Amino Alil Purificada

Figura 11. Preparação da fita simples de cDNA incorporada com amino alil com o kit "CyScribe Post Labelling"(GE Healthcare). 
Fita simples de cDNA incorporada com aminoalil purificada

ACOPLAMENTO DO cDNA COM CyDye-NHS ESTER
CyDye-NHS ester

Hidroxilamina

PURIFICAÇÃO DO cDNA

cDNA incorporado com CyDye e

CyDye não incorporado

MARCADO COM CyDye

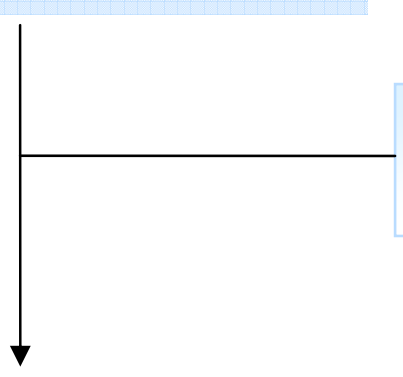

Colunas de purificação CyScribe GFX

cDNA marcado com CyDye purificado

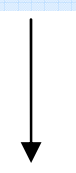

Hibridação com os microarrays

Figura 12. Preparação do cDNA marcado com CyDye com o kit "CyScribe Post Labelling" (GE Healthcare). 


\section{Preparação da primeira fita de cDNA por incorporação de AAdUTP}

Em um tubo Eppendorf de 1,5 $\mu$ l imerso em gelo picado foram adicionados $10 \mu \mathrm{g}$ de RNA total, $1 \mu \mathrm{l}$ de primers randômicos, $3 \mu \mathrm{l}$ de oligo (dT) e 0,5 $\mu \mathrm{l}$ de controle denominado "spike mix" para o Universal ScoreCard em um volume total de $11 \mu \mathrm{l}$ (Proporção de $2 \mu \mathrm{l}$ de spike mix para cada $1 \mu \mathrm{g}$ de RNA marcado). A reação foi cuidadosamente montada e incubada a $70^{\circ} \mathrm{C}$ por $5 \mathrm{~min}$, sendo posteriormente resfriada a $4^{\circ} \mathrm{C}$ durante $5 \mathrm{~min}$. A extensão da cadeia de cDNA foi realizada utilizando $4 \mu \mathrm{l}$ de tampão 5X CyScript , $2 \mu \mathrm{l}$ de DDT 0,1 M, $1 \mu 1$ de nucleotídeo "mix", $1 \mu 1$ de AA-dUTP (a quantidade de um tubo contendo AA-dUTP liofilizado foi ressuspenso em $30 \mu$ de água livre de nucleases e mantido a $-20^{\circ} \mathrm{C}$ por no máximo 30 dias), $1 \mu$ de transcriptase reversa CyScript, em um volume final de reação de $20 \mu \mathrm{l}$. A reação foi incubada a $42^{\circ} \mathrm{C}$ por 1,5 hora. Procedemos à degradação do RNAm adicionando $2 \mu \mathrm{l}$ de $\mathrm{NaOH} 2.5 \mathrm{M}$ com incubação a $37^{\circ} \mathrm{C}$ durante $15 \mathrm{~min}$, posteriormente foi adicionado $20 \mu \mathrm{lde}$ HEPES 2M.

a) Purificação do cDNA com colunas de purificação CyScribe GFX

Para cada amostra de cDNA com volume entre 20 a $100 \mu$ foram

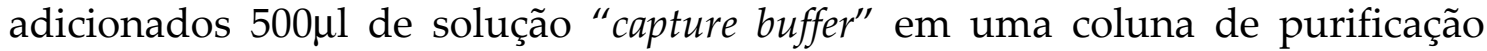
GFX colocada dentro de um tubo coletor. O produto de cDNA marcado com aminoalil não purificado foi adicionado à coluna e misturado 5 vezes. A centrifugação foi feita a 13800 xg por $30 \mathrm{seg}$. A coluna foi retirada e o líquido contido no tubo coletor foi descartado. A coluna foi novamente colocada no tubo coletor e foram adicionados $600 \mu \mathrm{l}$ de etanol $80 \%$. A centrifugação foi feita a $13800 \mathrm{xg}$ por $30 \mathrm{seg}$. A coluna foi retirada e o líquido contido no tubo coletor foi descartado. Esta lavagem foi repetida mais duas vezes. Uma nova centrifugação foi feita a 13800 xg por 10 seg. para retirada do excesso de etanol 
$80 \%$ da amostra. O tubo coletor foi descartado e a coluna contendo o cDNA foi colocada em um tubo de 1,5 $\mu$ l. Foi adicionada a coluna $60 \mu$ de bicarbonato de sódio 0,1 M pH 9,0 e incubado durante 5 minutos. O material foi centrifugado a 13800 xg por $1 \mathrm{~min}$.

\section{b) Incorporação de Cy3 e Cy5}

A amostra de cDNA marcada com aminoalil purificado foi adicionada a um tubo com a alíquota de CyDye NHS éster e ressuspendida várias vezes. $\mathrm{O}$ material foi centrifugado a 13800 xg por 1 min e incubado, no escuro, durante 1 hora. Posteriormente, foi adicionado $15 \mu \mathrm{l}$ de hidroxilamina $4 \mathrm{M}$ seguida de incubação no escuro, durante 15 min a temperatura ambiente.

c) Purificação do cDNA marcado com CyDye com colunas de purificação CyScribe GFX

Para cada amostra de cDNA com volume entre 20 a $100 \mu \mathrm{l}$ foram adicionados $500 \mu \mathrm{l}$ de solução "capture buffer" em uma coluna de purificação GFX colocada dentro de um tubo coletor. O produto de cDNA marcado com CyDye não purificado foi adicionado à coluna e misturado 5 vezes. A centrifugação foi feita a 13800 xg por 30 segundos. A coluna foi retirada e o líquido contido no tubo coletor foi descartado. A coluna foi novamente colocada no tubo coletor e foram adicionados $600 \mu \mathrm{l}$ da solução "wash buffer". A centrifugação foi feita a 13800 xg por 30 segundos. A coluna foi retirada e o líquido contido no tubo coletor foi descartado. Esta lavagem foi repetida mais duas vezes. Uma nova centrifugação foi feita a 13800 xg por 10 segundos para retirada do excesso da solução "wash buffer" da amostra. O tubo coletor foi descartado e a coluna contendo o cDNA foi colocada em um tubo de 1,5 $\mu$ l. Foi adicionado a coluna $60 \mu \mathrm{l}$ da solução "elution buffer" pré-aquecido à $65^{\circ} \mathrm{C}$ e 
incubado durante 5 minutos. O material foi centrifugado a 13800 xg por 1 minuto.

d) Quantificação do CyDye incorporado no cDNA

Após a purificação foi feita a monitoração de incorporação dos fluorocromos por meio de leitura em espectrômetro (Ultrospec 2100, GE Healthcare) em comprimento de onda a $550 \mathrm{~nm}$ para Сy3 e $650 \mathrm{~nm}$ para o Cy5 usando amostras diluídas 100X. A quantidade de Cy3 ou Cy5 incorporados no cDNA pode ser calculada através do seu coeficiente de extinção molar 1500001 $\mathrm{mol}^{-1} \mathrm{~cm}^{-1}$ para Cy3 e $2500001 \mathrm{~mol}^{-1} \mathrm{~cm}^{-1}$ para Cy5. As proporções de Cy3 e Cy5 incorporados no cDNA foram calculados pela fórmula: $(\mathrm{A}) / \mathrm{E} \times \mathrm{Z} \times$ fator de diluição $\times 10^{12}$, onde:

$$
\begin{aligned}
& A=\text { absorbância de Cy3 a } 550 \mathrm{~nm} \text { ou } C y 5 \text { a } 650 \mathrm{~nm} \\
& E=\text { coeficiente de extinção para Cy3 ou Cy5 } \times 10^{-6} \\
& Z=\text { volume }(\mu l) \text { da sonda após purificação }
\end{aligned}
$$

Para hibridações com os dois fluorocromos foram adicionados os cDNA marcado com Cy3 e Cy5 em um tubo de microcentrífuga protegido da luz. A solução de cDNA foi concentrada no aparelho "Speed Vacum". A seguir o cDNA foi dissolvido em $6 \mu$ l de água livre de nuclease e desnaturado a $95^{\circ} \mathrm{C}$ por $2 \mathrm{~min}$. A solução foi imediatamente resfriada no gelo por 30 seg. A essa reação adicionamos $1,5 \mu \mathrm{l}$ de $\mathrm{A}_{80}(1 \mathrm{mg} / \mathrm{ml})$ e incubamos a $75{ }^{\circ} \mathrm{C}$ por $45 \mathrm{~min}$, estando assim pronta para o processo de hibridação. 


\subsubsection{HIBRIDAÇÃO DAS LÂMINAS DE MICROARRAYS}

As lâminas de microarrays foram hibridadas utilizando um processador automático de lâminas, "Lucidea Automated Slide Processor"-ASP (GE Healthcare) que permite a hibridação e lavagens de lâminas em câmaras independentes (12 lâminas por vez). Este aparelho inclui um software que automatiza a injeção de amostras líquidas e soluções de lavagens ou ar dentro das câmaras e possui parâmetros de controle de temperatura e velocidade de injeção e circulação destas soluções no interior das mesmas.

As lâminas foram hibridadas por 15 horas a $42^{\circ} \mathrm{C}$. As condições de lavagens foram: 1 XSSC/0,2\%SDS ( 2 x 20 seg. à temperatura ambiente); $0,1 \mathrm{X}$ SSC/0,2\% SDS ( $2 \times 20 \mathrm{seg}$. à temperatura ambiente); 0,1X SSC ( $2 \times 20 \mathrm{seg}$. à temperatura ambiente). A última lavagem das lâminas foi feita com isopropanol, sendo em seguida aquecidas a $42^{\circ} \mathrm{C}$, e novamente lavagem com isopropanol. Após as lavagens as lâminas foram aquecidas a $60^{\circ} \mathrm{C}$ para secagem. As lâminas estavam prontas para serem "lidas" em aparelho "scanner" a laser.

\subsubsection{AQUISIÇÃO DE IMAGENS DE MICROARRAYS}

As lâminas foram lidas num aparelho Generation III "Array Scanner" (GE Healthcare) com lasers de 532nm para o Cy3 (verde) e $633 \mathrm{~nm}$ para o Cy5 (vermelho). A leitura da lâmina gera dois arquivos com imagens separadas com os pontos em preto para os dois canais (Cy3 e Cy5) e uma terceira imagem, agora colorida, sobrepondo Cy3 e Cy5 visualizadas usando o software ImageQuant (GE Healthcare). Estas imagens podem ser observadas na Figura 28 (Anexo I). 


\subsubsection{QUANTIFICAÇÃO E NORMALIZAÇÃO DOS DADOS DE} MICROARRAYS

Após obtenção das imagens seguiu-se à análise realizada em duas etapas.

- Inicialmente, os dados contidos nas imagens foram transformados em dados numéricos, utilizando o programa Spotfinder (http://www.tigr.org/software). Esse programa, além de transformar as informações das imagens em valores numéricos, também analisa a qualidade dos pontos e calcula o "background". Dois parâmetros foram considerados para o controle de qualidade neste programa: os pontos de boa qualidade apresentam valores superiores e/ou igual a 1 valor "backgrounds" mais 1 valor desvio padrão.

- Em seguida, estes dados foram normalizados. A normalização retira os erros experimentais sistemáticos por balancear a intensidade dos dois fluorocromos. Esses erros podem ocorrer devido à diferença de incorporação dos corantes, efeitos espaciais na lâmina e diferenças durante a aquisição das imagens nos dois canais. Para esses ajustes, utilizou-se a plataforma $\mathrm{R}$ (www.r-project.org), com o pacote AROMA (http://www.maths.lth.se/help/R/aroma/), que retém as funções necessárias para a normalização dos dados de microarrays. Portanto, após a retirada do background pelo programa Spotfinder, os dados foram importados para o ambiente $\mathrm{R}$ e transformados para o formato de dados "M versus $\mathrm{A}$ ", onde $\mathrm{M}$ é igual a $\log 2(R / G)$ e A é igual a $1 / 2 \cdot \log 2(R \cdot G)$. Em seguida, os métodos de normalização "print-tip Lowess" e "absolute median deviation (MAD) rescaling" foram aplicados respectivamente. O primeiro método aplica uma regressão linear nos dados, para corrigir erros espaciais que possam ter sido gerados durante os experimentos. O segundo re-escalona as razões de log para cada microarray, de maneira que cada slide adquire a mesma distribuição dos dados, de acordo com a MAD, capaz de estimar com robustez a variância de uma amostra. Na figura 13, observamos o fluxograma da "pipeline" desenvolvida para análise dos dados. 


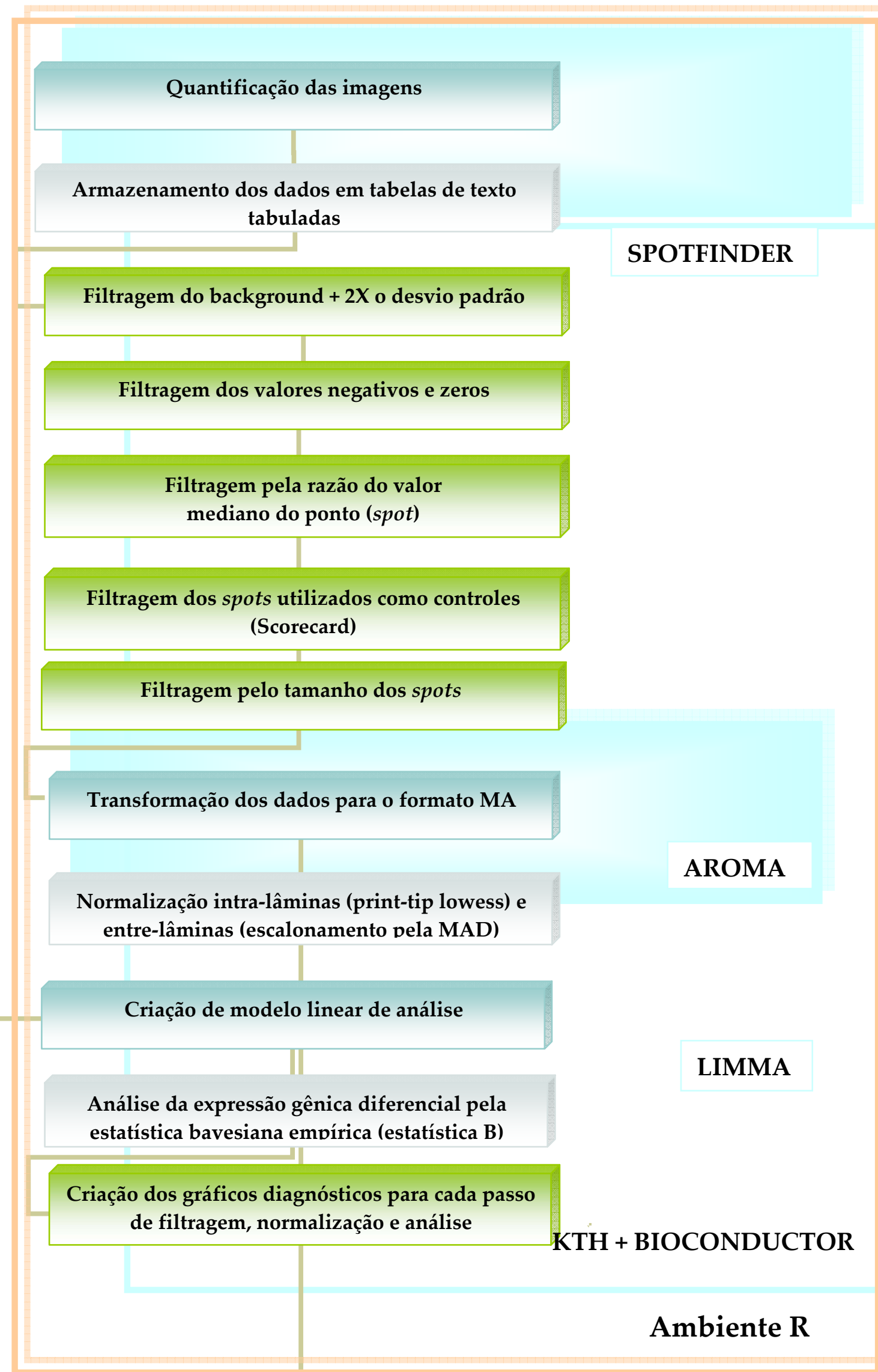

Figura 13. "Pipeline" utilizac o na análise de dados de microarrays em lâminas de vidro. 
Utilizando o pacote LIMMA (Linear Models for Microarray Data) (Smith, 2004) foi aplicado o método Bayesiano empírico para análise estatística da expressão diferencial.

Posteriormente, o programa SAM ("Significance Analysis of Microarrays") (Tusher et al. 2001) foi utilizado para a detecção dos genes diferencialmente expressos (Smyth 2004).

O programa SAM representa uma evolução dos softwares de análise estatística para a tecnologia de microarrays e encontra-se disponível no endereço (http://www-stat.stanford.edu/ tibs/SAM/). A análise baseia-se em uma série de testes-t específicos para cada gene, que são adaptados para a detecção da expressão gênica diferencial em larga escala. A partir da observação de que as flutuações casuais são específicas para cada gene, o teste SAM é baseado na razão entre a diferença das médias das situações, como por exemplo, pool de órgãos $\left(X_{c}\right)$ e o timo $(X p)$, e o desvio padrão de cada gene, calculados a partir de repetição experimental. A diferença relativa $\mathrm{d}(i)$ na expressão gênica é então definida pela equação 1:

[EQUAÇÃO 1]

$$
d(i)=\frac{X_{p}(i)-X_{c}(i)}{S(i)+S_{0}}
$$

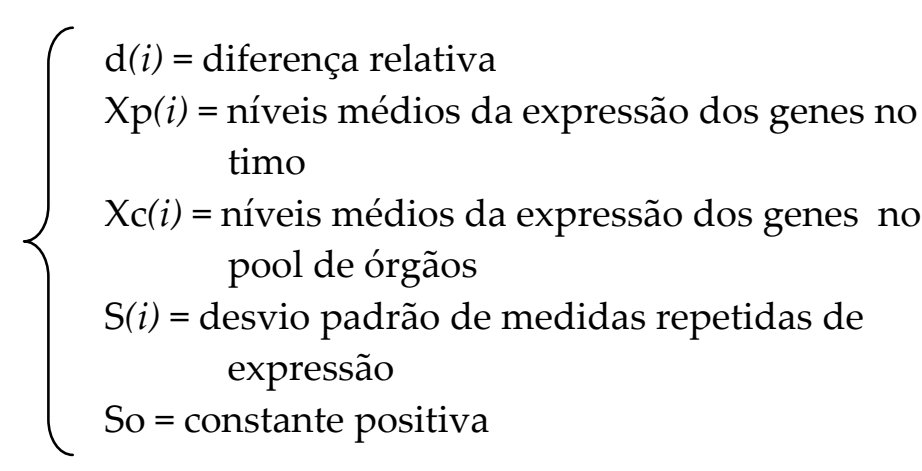

Onde $X_{p}(\mathrm{i})$ e $X_{c}(i)$ são definidos como níveis médios da expressão do gene nos estados p (timo) e c (pool de órgãos), respectivamente. A dispersão gene-específica S(i) é o desvio padrão de medidas repetidas de expressão, e a constante positiva So no denominador da equação acima, servem para 
certificação de que a variância de d(i) é independente da expressão gênica. Para a determinação de genes com mudanças significativas na expressão, utilizou-se um gráfico de dispersão d(i), em relação à diferença relativa esperada dE.(i). Para uma grande maioria de genes $\mathrm{d}(\mathrm{i}) \cong \mathrm{d}_{\mathrm{E} .(\mathrm{i}) \text {, mas alguns genes são }}$ representados por pontos distantes da linha $\mathrm{d}(\mathrm{i}) \cong \mathrm{d}$.(i). As alterações das expressões dos genes que se encontram a uma distância maior do que o limiar $(\Delta)$ é então considerado significante (Figura 14).

O limiar $(\Delta)$ determina dois cortes horizontais, ou seja, o menor valor de d(i) indica que o gene seja considerado significantemente induzido (hiperexpresso), e o valor menos negativo de $\mathrm{d}(\mathrm{i})$ indica que o gene está significantemente reprimido (hipoexpresso).

A porcentagem de genes identificados por mudanças aleatórias é chamada de Freqüência de Descobertas Falsas (FDR), um método inicialmente idealizado por Benjamini \& Hochberg (1995) e definido como a proporção esperada de rejeições falsas. O cálculo de FDR e o número de genes com mudanças significativas estão intimamente relacionados com o limiar $\Delta$. À medida que o valor de $\Delta$ diminui, o número de genes significantemente alterados aumenta à custa de um aumento de um FDR. Essa determinação do nível de significância pelo limiar providencia cortes assimétricos para genes induzidos e genes reprimidos. Essa assimetria é desejável, posto que os genes induzidos e genes reprimidos podem se comportar de maneira diferente em alguns experimentos. Ao utilizar o SAM, o usuário pode escolher o limiar $\Delta$ mais conveniente com base no nível de significância estimado pelo FDR e no número de genes com os quais se pretende trabalhar.

O programa SAM estabelece automaticamente uma ligação entre o número de acesso das seqüências utilizadas com as páginas de informações sobre o clone em questão, situados no banco de dados S.O.U.R.C.E. ("Stanford Online Universal Resource for Clones and ESTs") (http://source.stanford.edu/cgibin/source/sourceSearch). O S.O.U.R.C.E. compila informações de vários 
bancos de dados públicos (UniGene, dbEST, Swiss-Prot, GeneMap99, RHdb, GeneCards e LocusLink) e as disponibilizam de maneira a facilitar a identificação dos genes diferencialmente expressos.

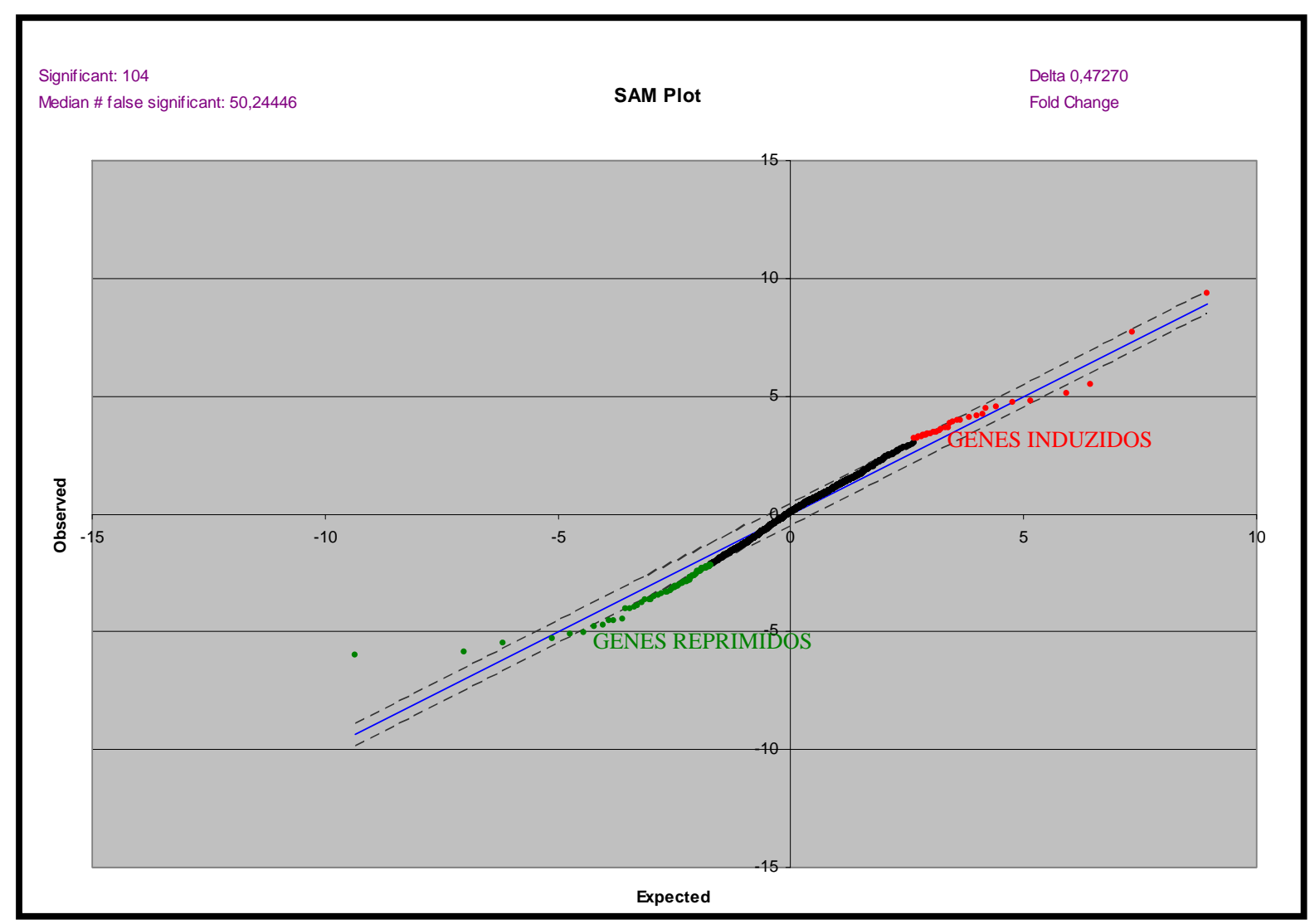

Figura 14: Comparação entre a distância relativa observada d(i) e esperada dE(i).

Todas as informações citadas acima foram retiradas do trabalho de Tusher et al. 2001, do manual do software SAM e de relatórios técnicos publicados na página de Robert Tibshirani (http://wwwstat.stanford.edu/ tibs/SAM). 


\subsubsection{NOMENCLATURA DOS GENES}

Neste trabalho, optou-se por seguir a nomenclatura usual para genes de camundongos, ou seja, o símbolo do gene em inglês com a primeira letra maiúscula e as seguintes minúsculas (exemplo: Aire para Autoimmune regulator). O nome dos genes por extenso, exemplo Autoimmune regulator, com a primeira letra maiúscula e as outras minúsculas. Os nomes dos genes estão em inglês, pois toda a literatura e os bancos de dados internacionais como Source, GenBank etc. estão neste idioma. Além disso, todos os arquivos da biblioteca de cDNA estão em inglês.

\subsection{PREPARAÇÃO DE cDNA MICROARRAYS EM NÁILON}

\subsubsection{BIBLIOTECA DE CDNAS MURINOS}

Para a preparação dos microarrays em náilon foram utilizadas as seguintes bibliotecas de cDNA : um grupo de clones de cDNA "NIA Mouse 15K", 2NbMT (timo), NbMLN (linfonodos), e 3NbMS (baço). As descrições detalhadas destas bibliotecas estão disponíveis no site da base de dados UniGene (www.ncbi.nlm.nih.gov/UniGene/lbrowse2.cgi?TAXID=10090). Todas as bibliotecas foram clonadas no vetor pT3T7D-Pac, à exceção do grupo de clones de cDNA "NIA Mouse 15K", que foi clonado no vetor pSPORT1. Os clones de cDNA desta biblioteca é um grupo de clones rearranjados e ressequenciados de um jogo de 15.000 clones bacterianos derivados de 11 bibliotecas de cDNA de embrião. Estas foram obtidas do "Medical Research Council Geneservice" (www.geneservice.co.uk) (Cambridge, Reino Unido). 2NbMT, NbMLN, e 3NbMS são bibliotecas arranjadas em seqüência de I.M.A.G.E. que foram obtidas do "Deutsches Ressourcenzentrum für Genomforschung Resource Centre" (RZPD) (www.rzpd.de)(Berlim, Alemanha). 
Os clones de cDNA foram anotados de acordo com UniGene usando a base de dados SOURCE antes da seleção bioinformática e da reorganização robótica. Um total de 4300 clones foi selecionado e as seqüências foram confirmadas.

Ao final o conjunto inclui 8750 seqüências de cDNA clonadas em E.coli com uma representação de 7770 conjuntos não redundantes de UniGene. Embora o índice de genes deste grupo de clones seja exaustivo, alguns reguladores chaves da maturação das células $\mathrm{T}$ ainda estão faltando (por exemplo, RAG-1, RAG-2 e ZAP-70). Aproximadamente 10\% dos genes incluídos neste grupo de clones são representados por dois ou mais clones diferentes de cDNA, fornecendo controles internos para avaliar o reprodutibilidade de medidas da expressão.

\subsubsection{AMPLIFICAÇÃO DE CDNA PARA A CONFECÇÃO DE MICROARRAYS EM NÁILON}

A amplificação das seqüências de cDNA por reação de polimerização em cadeia (PCR) foi feita em placas de 96 poços usando os seguintes primers: 5'CCAGTCACGACGTTGTAAAACGAC - $\quad 3^{\prime}$ e 5'GTGTGGAATTGTGAGCGGATAACAA - 3' obtidos a partir da seqüência “polylinker" de ambos vetores (pT3T7D-Pac e pSPORT1).

As reações foram feitas de acordo como descrito por Diehl et al., 2002, por meio de repique dos clones de E. coli na fase de crescimento por meio de um robô de bancada com 96 agulhas (Genetix, New Milton, Reino Unido) com adição de um mix de $100 \mu$ l, contendo: 10 mM Tris- $\mathrm{HCl}$ (pH 9), 1.5 mM MgCl2, $50 \mathrm{mM} \mathrm{KCl}$, 0,1\% Triton X-100, 1,5 M betaína, $250 \mu \mathrm{M}$ dATP, dTTP, dGTP e dCTP, e 5 U de Taq polimerase (Promega, Madison, WI);

Seguiu-se de incubação por $6 \mathrm{~min}$ a $94^{\circ} \mathrm{C}$, seguida por 38 ciclos de: $94^{\circ} \mathrm{C}$ por $30 \mathrm{~s}, 65^{\circ} \mathrm{C}$ por 45 minutos e $72{ }^{\circ} \mathrm{C}$ por $210 \mathrm{~s}$, e uma etapa final de 
elongamento a $72^{\circ} \mathrm{C}$ por 10 minutos. Os produtos de amplificação não foram quantificados, mas a qualidade foi avaliada em gel de agarose 1\%, obtendo uma estimativa $11 \%$ de não-amplificação e $4 \%$ de bandas múltiplas (não-específicas).

Esta etapa foi conduzida usando um robô chamado MicroGrid-II arrayer (Apogent Discoveries, Cambridge, Reino Unido.) equipado com 64 agulhas.

\subsubsection{DETECÇÃO DO PADR ÃO DE PONTOS POR HIBRIDAÇÃO COM OLIGO- VETOR}

A hibridação com um oligo-vetor (seqüência complementar a um segmento do vetor da biblioteca que ainda permanece nos produtos de PCR) têm por finalidade estimar a quantidade de DNA retida em cada ponto do microarray. Os resultados dessa hibridação inicial com o vetor são utilizados em um passo de correção dos dados obtidos pelas sondas complexas de RNA (cDNA). Meio micrograma do oligo-vetor 1 AS (5'GGG TTG AAT TAG CGG AAC G 3') (500 $\mu \mathrm{l} 1 \mathrm{M}$ ) foi marcado com fósforo radioativo segundo o seguinte protocolo: $3 \mu \mathrm{l}\left[\gamma^{-33} \mathrm{P}\right]$ ATP $5000 \mathrm{Ci} / \mathrm{mM}$ (GE Healthcare) foram misturados com $1 \mu \mathrm{l}$ de $\mathrm{T} 4$ polinucleotídeo quinase (Invitrogen, 10U/ $\mu \mathrm{l}$ ), $4 \mu \mathrm{l}$ de tampão 5X Forward reaction buffer e 10,25 $\mu \mathrm{l}$ de água milli-Q autoclavada (qsp $20 \mu \mathrm{l}$ ), sendo a mistura incubada durante 45 minutos a $37^{\circ} \mathrm{C}$. Em seguida, foi acrescentado $80 \mu \mathrm{l}$ de água milli-Q autoclavada e, posteriormente, a sonda-vetor foi purificada em uma coluna com Sephadex G50 montada numa seringa plástica de $1 \mathrm{ml}$, durante 10 minutos a $65^{\circ} \mathrm{C}$, para a eliminação do ${ }^{33} \mathrm{P}$ nucleotídeos não incorporados na sonda-vetor.

A taxa de incorporação do ${ }^{33} \mathrm{P}(\mathrm{cpm} / \mathrm{ml})$ foi avaliada pela leitura de $1 \mu \mathrm{l}$ da sonda em $5 \mathrm{ml}$ de líquido cintilador (Ultimagold, Packard) em aparelho de cintilação líquida (Packard Tricarb,USA). As sondas foram consideradas de boa qualidade quando apresentaram de 30 a 50 x $10^{6}$ cpm em $100 \mu \mathrm{l}$.

Todas as membranas foram submetidas à pré-hibridação overnight a $42^{\circ} \mathrm{C}$ 
em $12 \mathrm{ml}$ de solução de pré-hibridação, que é composta por SSC 5x, Denhart's 5x (10g de Ficoll, $10 \mathrm{~g}$ de polivinil pirrolidona, $10 \mathrm{~g}$ de fração de albumina bovina, completar com água mili-Q qsp $1000 \mathrm{ml}$ ), SDS 0,5\%, com $240 \mu \mathrm{g} / \mathrm{ml} \mathrm{de}$ DNA de esperma de salmão desnaturado). Posteriormente, procedeu-se à hibridação overnight a $42^{\circ} \mathrm{C}$ com o oligo-vetor marcado $(40.000 \mathrm{cpm} / \mathrm{ml})$, seguida de lavagem das membranas com 1 litro de tampão SSC 2x/SDS 0,1\%, por 10 minutos, à temperatura ambiente e por mais 5 minutos, com a mesma quantidade de tampão aquecido a $42^{\circ} \mathrm{C}$. Então, as membranas foram expostas durante 18 horas a placas sensíveis à radioatividade, as quais foram lidas pelo aparelho leitor de fósforo incorporado (BAS 5000 Fuji, Tokyo, Japão).

Após a aquisição das imagens das membranas hibridizadas com o oligovetor, foi realizado a desibridização para posterior uso dos microarrays com as sondas complexas. Para isto, as membranas foram lavadas em $1000 \mathrm{ml}$ de solução SSC 0,1X/0,1\% SDS, durante 1,5 horas a temperatura de $68^{\circ} \mathrm{C}$, havendo troca da solução a cada meia hora. Logo, as membranas foram mergulhadas em tampão SSC $2 \mathrm{X}$ e expostas novamente, durante 72 horas, às placas sensíveis à radioatividade, as quais foram lidas pelo aparelho leitor de fósforo (BAS 5000 Fuji, Tokyo, Japão).

\subsubsection{PREPARAÇÃO DAS SONDAS COMPLEXAS A PARTIR DAS} AMOSTRAS DE RNA TOTAL

As sondas complexas de cDNA foram preparadas a partir de RNA total extraído dos timos e dos outros órgãos fetais dos animais submetidos ao procedimento experimental proposto. Cinco microgramas de RNA total de cada amostra e mais $1 \mu \mathrm{g}$ de oligonucleotídeo (dT25) foram aquecidos a $70^{\circ} \mathrm{C}$ para a remoção de estruturas secundárias de RNA, e resfriados progressivamente em uma máquina de $\mathrm{PCR}$ até $42^{\circ} \mathrm{C}$. Esse processo é utilizado para garantir o anelamento do oligo (dT25) com as caudas poli-A dos RNA mensageiros 
(RNAm).

Posteriormente, as sondas complexas foram preparadas pela reação de transcrição reversa e marcação de DNA fita simples. Esta reação ocorre por 2 horas a $42^{\circ} \mathrm{C}$ na presença de $3 \mu \mathrm{l}$ de $10 \mathrm{uCi} / \mu \mathrm{l}\left(\alpha^{33} \mathrm{P}\right) \mathrm{dCTP}(>3000 \mathrm{Ci} / \mathrm{mM}), 0,6 \mu \mathrm{l}$ da mistura dos dNTPs (20mM de dATP, dTTP e dGTP), 0,6 4 l de dCTP 120 $\mu \mathrm{M}$, $2 \mu \mathrm{l}$ de DTT 0,1M, $1 \mu 1$ de Rnasin (inibidor de ribonuclease), $6 \mu l$ de tampão da transcriptase reversa $5 \mathrm{x}, 1 \mu \mathrm{l}$ de transcriptase reversa (SuperScript RNase H free $R T, 200 \mathrm{u} / \mu \mathrm{l}$ (Invitrogen), sendo esta acrescentada somente após uma hora de

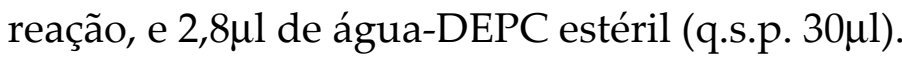

Para eliminar os RNAm moldes e os RNAs ribossômicos (RNAr), as sondas foram incubadas, durante 30 minutos a $68^{\circ} \mathrm{C}$, com $1 \mu \mathrm{l}$ de SDS $10 \%, 1 \mu \mathrm{l}$ de EDTA $0,5 \mathrm{M}$ e $3 \mu \mathrm{l}$ de $\mathrm{NaOH} 3 \mathrm{M}$ e deixados à temperatura ambiente por mais 15 minutos. A posterior neutralização foi realizada pela da adição de $10 \mu \mathrm{l}$ de Tris- $\mathrm{HCl} 1 \mathrm{M}$ e $3 \mu \mathrm{l}$ de $\mathrm{HCl} 2 \mathrm{~N}$. Os nucleotídeos não incorporados foram removidos por meio da passagem em coluna de Sephadex G50 montada em seringa plástica de $1 \mathrm{ml}$.

A radioatividade total foi avaliada pela leitura de $1 \mu \mathrm{l}$ da sonda em $5 \mathrm{ml}$ de líquido cintilador (UltimaGold, Packard) num aparelho Liquid Scintilator (Packard Inst., USA). As sondas foram consideradas de boa qualidade quando apresentaram aproximadamente 40000 cpm em $100 \mu$ l. Após acrescentar às sondas $2 \mu \mathrm{g}$ de poli-A80 e desnaturá-las por 5 minutos a $100^{\circ} \mathrm{C}$, estas foram incubadas em $1 \mathrm{ml}$ de tampão de hibridação pré-aquecido, durante 2,5 horas a $65^{\circ} \mathrm{C}$, com a finalidade de proporcionar a hibridação do oligo A80 com as caudas poli-T remanescentes da reação de transcrição reversa. Após este procedimento, as sondas estavam prontas para hibridar com microarrays em náilon. 


\subsubsection{HIBRIDAÇÃO DAS SONDAS COMPLEXAS DE cDNA COM OS MICROARRAYS EM NÁILON}

As membranas de náilon (microarrays) foram submetidas à préhibridação durante 6 horas, tendo em cada tubo/membrana $500 \mu$ l de solução de pré-hibridação com constituição igual à utilizada para a hibridação com oligo-vetor. A hibridação com a sonda complexa foi realizada a $68^{\circ} \mathrm{C}$ durante 48 horas. Após a hibridação, as membranas foram lavadas, durante 3 horas, em $1000 \mathrm{ml}$ de solução de $0,1 \times S S C, 0,4 \%$ SDS a $68^{\circ} \mathrm{C}$, e expostas em placas de sensibilidade à radioatividade durante 3 horas para estimarmos a eficiência das lavagens e presença ou não de backgrounds.

Se necessário fosse, após as lavagens, as membranas foram reexpostas às placas de sensibilidade à radioatividade, as quais foram lidas com 20 horas de exposição.

\subsubsection{AQUISIÇÃO DE IMAGENS E PROCESSAMENTO DOS DADOS DE MICROARRAYS}

Após a aquisição das imagens, os sinais foram quantificados usando o software Bzscan desenvolvido pelo grupo TAGC-INSERM (http://tagc.univmrs.fr/ComputationalBiology/bzscan/index.php). Todas as imagens foram inspecionadas com cuidado (Figura 28 - Anexo I), e os pontos com as intensidades superestimadas devido aos efeitos da vizinhança foram excluídos manualmente. Para cada uma das disposições, os backgrounds foram calculados e subtraídos. Nós definimos classes distintas das amostras, cada uma delas que contêm todas as réplicas do mesmo tipo da amostra (por exemplo, quatro réplicas de timo de 14 dias p.c. definem uma classe). Os dados foram filtrados $(80 \%)$, transformados em log2, e foram centrados relativamente ao número médio para cada gene e cada disposição usando o software Bzscan, ambiente R e o agrupamento hierárquico (Figura 15). 
Quantificação das imagens e filtragem dos dados

(aproveitamento de $80 \%$ )

Bzscan

Armazenamento dos dados em tabelas de texto tabuladas

Correção dos "efeitos de vizinhança" e do background local sobre os dados do vetor e sonda complexa

Normalização aplicada ao vetor e a sonda complexa para corrigir a intensidade global e a dispersão

Normalização intra-arrays (print-tip lowess) e entre-arrays

AROMA

KTH + BIOCONDUCTOR

Dados centrados com relação à mediana de cada gene

\section{Ambiente R}

Figura 15. "Pipeline" utilizado na análise de dados de microarrays em náilon. 
Diferentes programas estão disponíveis para o processamento do agrupamento hierárquico, porém, o mais importante na elaboração deste agrupamento é a decisão sobre qual medida de similaridade será adotada, a necessidade de se transformar a escala dos valores de expressão (normalmente transformada em escala logarítmica) e a dependência dos genes entre si. $\mathrm{O}$ agrupamento hierárquico foi realizado utilizando-se o programa Cluster e a visualização da matriz de expressão no programa TreeView (Einsen et al., 1998). Ambos os programas podem ser encontrados no site (http://rana.lbl.gov/EisenSoftware.htm).

Para analisar genes em que os níveis de expressão flutuaram dentre as amostras, somente foram mantidas seqüências que exibiram um score $D$ menor de 0.05. Agrupamento hierárquico foi aplicado à série de dados por meio do programa Cluster, e os resultados foram visualizados com o software TreeView (http://rana.lbl.gov/EisenSoftware.htm).

Por meio desses programas gerou-se um heat map (mapa de cores relacionado com o nível de expressão dos genes) para os valores. O heat map é composto por um código de cores a fim de facilitar a associação visual dos níveis de expressão gênica. Em paralelo, criou-se um dendrograma demonstrando as relações de proximidade entre os genes baseando-se nos perfis de expressão. Desta forma, uma vez detectados os agrupamentos funcionais, cabe ao pesquisador a elaboração de hipóteses para tentar explicar um efeito biológico. 
RIESIUILTCADD)OS 


\section{RESULTADOS}

\subsection{CARACTERÍSTICAS MORFOLÓGICAS DO DESENVOLVIMENTO FETAL}

A utilização dos dados das características morfológicas de desenvolvimento durante a gestação mostrada na Tabela I e Figuras 6 e 7, possibilitaram a determinação das idades fetais até o $16^{\circ}$ dia de gestação, e em alguns casos até $17^{\circ}$ dia, pois para as idades posteriores seria necessário utilizar a análise de mudanças internas, como por exemplo, os centros de ossificações. Alguns fetos, tanto mais jovens quanto mais tardios são difíceis de precisar a idade, por possuírem características comuns de mais de uma idade, porém a maioria é possível de determinar.

Como a fase do desenvolvimento que mais nos interessou neste trabalho foi o período compreendido entre os 14 aos 17 dias de gestação, não foi necessário lançarmos mão da monitoração das estruturas internas.

A Figura 16 nos mostra a evolução das características morfológicas durante a gestação de um camundongo. Em fetos com 13 dias $(10 \mathrm{~mm}$ de comprimento) já é possível observar membros anteriores formados por uma placa recortada e os membros posteriores formados por placas de formato pentagonal, ainda pode-se observar o aparecimento de um rudimento de orelha e a delimitação do olho.

Em fetos com 14 dias $(12 \mathrm{~mm})$ observa-se os membros anteriores formados por dígitos separados, mas ainda próximos à palma, e os membros posteriores formados por placas bem mais recortadas; também nota-se o meato auditivo e o aparecimento da pinna (uma fina lâmina de pele dobrada que cresce no sentido do meato auditivo).

Com 15 dias de gestação os fetos apresentam $15 \mathrm{~mm}$ e pode-se observar uma separação mais pronunciada dos dígitos e o aparecimento da córnea. Em 
fetos com 16 dias (18 mm) observa-se a definição das extremidades das falanges, assim como a definição da orelha e a fusão das pálpebras.

Já em fetos com 17 dias (19 mm) os pés e dedos apresentam-se como em recém-nascidos e a pinna cobre completamente o meato auditivo. Alguns fetos apresentam certa dificuldade de se precisar à idade, pois possuem características comuns a mais de uma idade.

Estas observações nos permitiram determinar com precisão a idade de cada um dos fetos dos quais foram extraídos DNA e RNA. Além disso, fizemos a inspeção visual para acompanhar o aparecimento do "plug" vaginal na manhã seguinte ao coito, o que demarcou o dia zero da gestação.

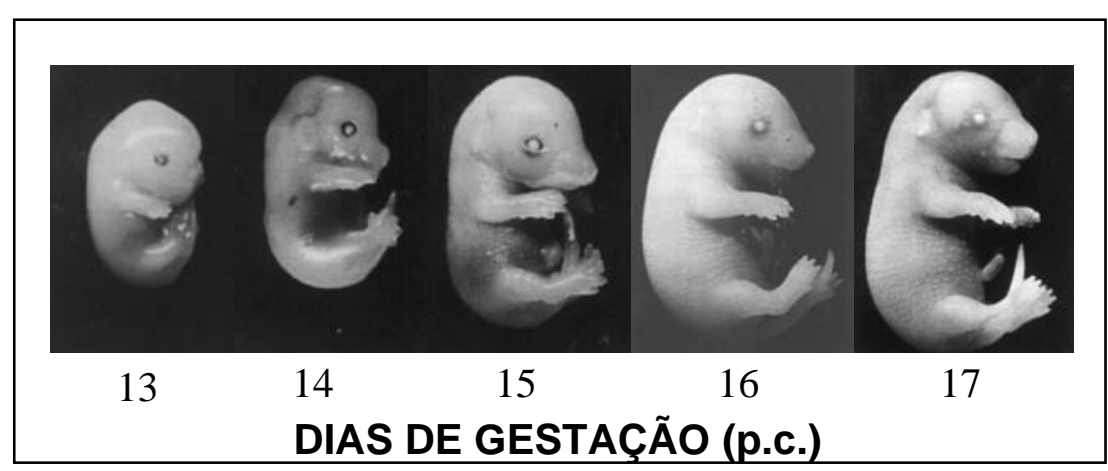

Figura 16. Evolução das características morfológicas de fetos com idades de 13 a 17 dias de gestação (p.c.).

\subsection{ANÁLISE DA INTEGRIDADE DAS AMOSTRAS DE RNA TOTAL}

As amostras de RNA total obtidas de órgãos de fetos de camundongos das diferentes linhagens (Balb-c, C57Bl/6 e seus híbridos) foram submetidas à eletroforese em gel de agarose desnaturante 1,5\% para análise de sua integridade. Na Figura 17, pode-se observar as subunidades $28 \mathrm{~S}$ e $18 \mathrm{~S}$ de RNAr, mostrando a integridade e a qualidade da preparação, e também observa-se o pool de RNAt (4 S) junto com RNAr 5 S. 


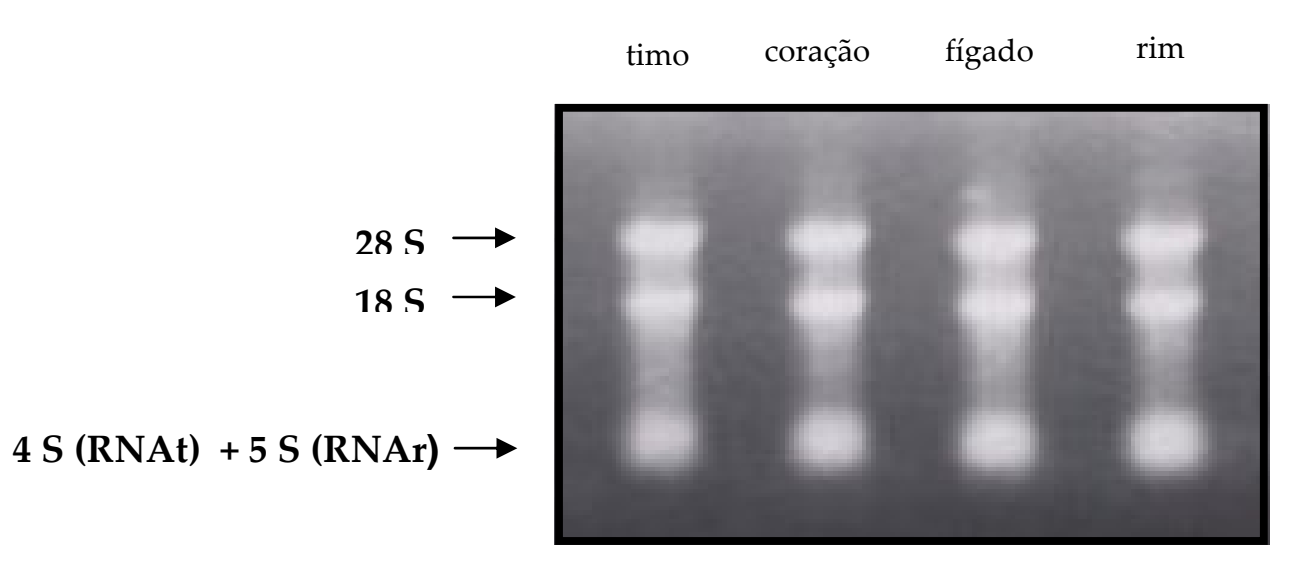

Figura 17. Eletroforese em gel de agarose 1,5\% mostrando o fracionamento das amostras de RNA total de alguns órgãos de fetos de camundongos.

\subsection{CONFIRMAÇÃO DA INTEGRIDADE DO RNA POR NORTHERN-} BLOT

As amostras de RNA total aplicadas no gel de agarose 1,5\% foram transferidas para membranas de náilon e, posteriormente, submetidas à técnica de hibridação Northern-blot com oligonucleotídeo radioativo que reconhece o RNAr 28 S, a fim de se obter a confirmação da integridade destas amostras. Na Figura 18 pode-se observar uma banda nítida de RNAr 28 S das amostras de RNA total analisadas, com isso comprovamos a integridade das preparações. A confirmação de tal integridade se faz necessária para utilização destas amostras no preparo das sondas complexas de cDNA.

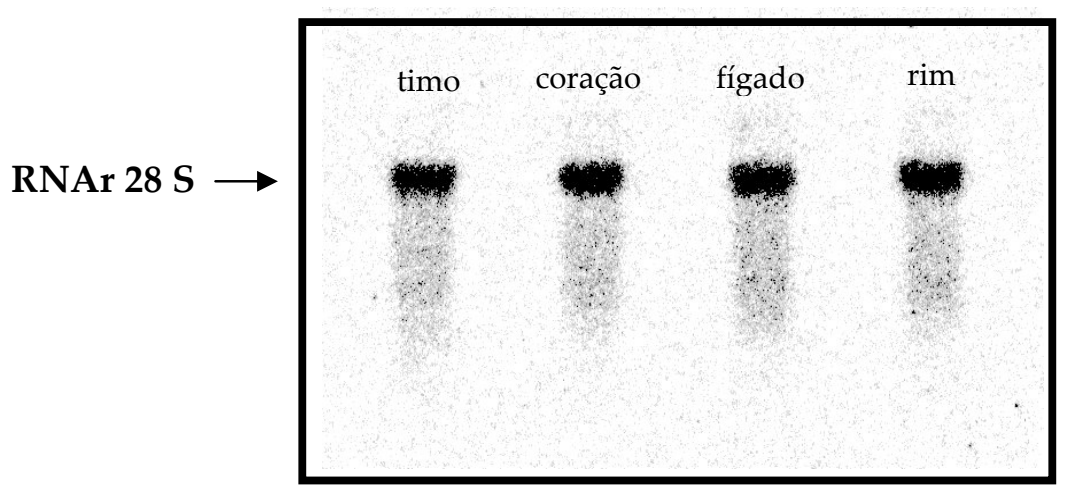

Figura 18. Hibridação Northern-blot de amostras de RNA de órgãos fetais, utilizando como sonda um oligonucleotídeo marcado com ${ }^{33} \mathrm{P}$ que reconhece o RNAr $28 \mathrm{~S}$. 


\subsection{CONFIRMAÇÃO DA INTEGRIDADE DO RNA TOTAL PELA TÉCNICA AGILENT (LAB-ON-CHIP)}

As amostras de RNA dos timos fetais de camundongos da linhagem C57Bl/6, utilizadas nos experimentos com microarrays em náilon no Laboratório TAGC INSERM de Marseille, França, foram submetidas à eletroforese pela tecnologia Agilent para análise de sua integridade. Na figura 19, pode-se observar as subunidades de RNAr 28 S e 18 S, o pool de RNAt (4 S) junto com RNAr 5 S.

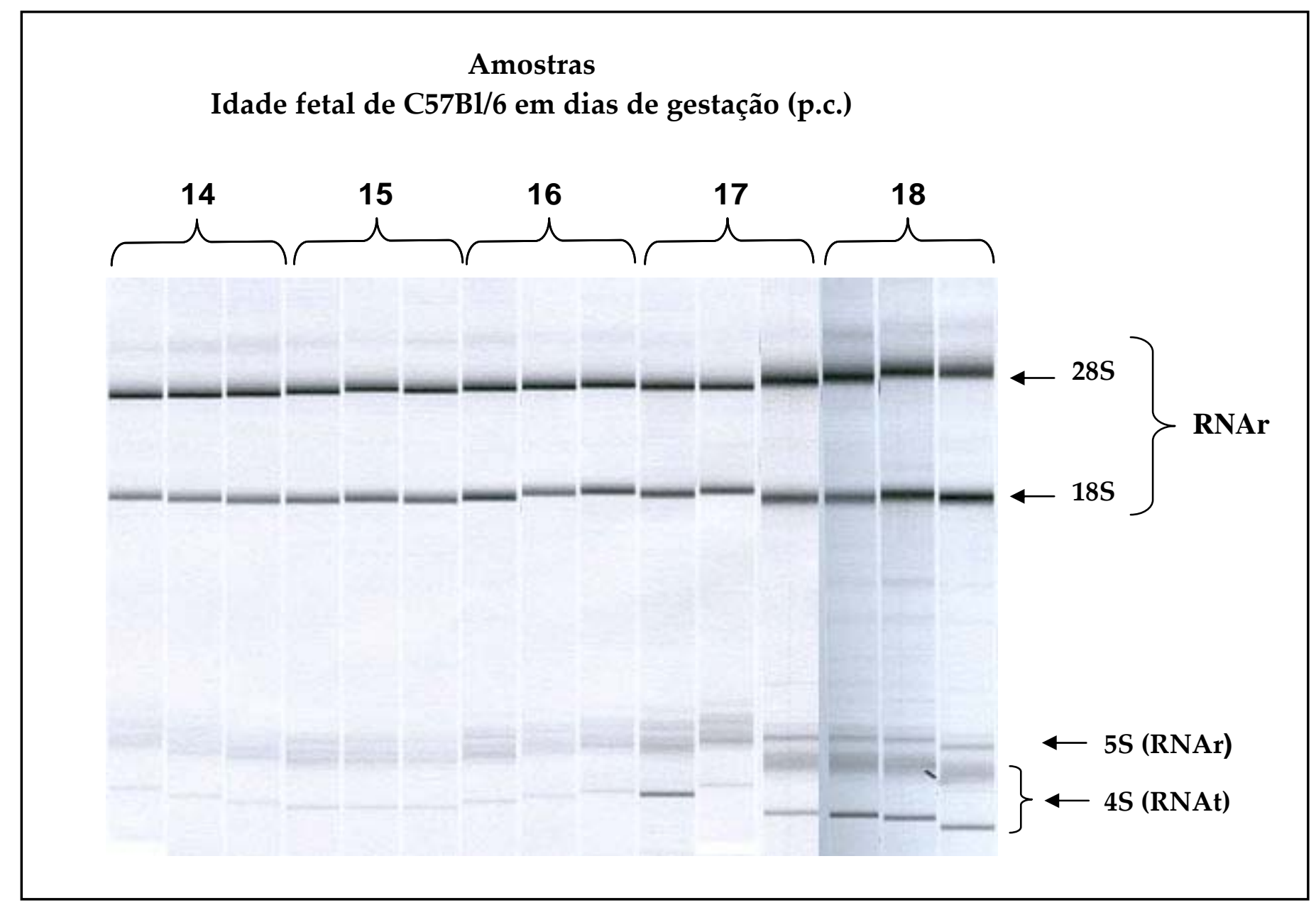

Figura 19. Eletroforese pela tecnologia Agilent (Lab-on-Chip) mostrando o fracionamento das amostras de RNA total de timo de fetos de camundongos. 


\subsection{AMPLIFICAÇÃO DOS CLONES DE cDNA PELA TÉCNICA DE PCR}

Amplificamos os insertos de cDNA da biblioteca MTB IMAGE utilizando os clones bacterianos intactos adicionados ao " $m i x$ " da PCR. Isto facilitou em muito a rotina do laboratório, pois eliminamos, com sucesso, um passo de isolamento dos plasmídeos. Num projeto como este, em que fazemos milhares de reações de PCR, isto representou enorme economia de tempo e material de consumo. Posteriormente, os produtos PCR foram purificados eliminando-se os oligonucleotídeos "primers" não incorporados e os "debris" celulares.

Obtivemos pelo menos $80 \%$ de positividade na amplificação dos clones da biblioteca e produtos de PCR com um ótimo grau de pureza. Nos testes de padronização observamos que a concentração dos produtos de PCR, os quais deveriam estar numa faixa entre 100 a 200 ng/ $\mu 1$ de solução de espotagem, apresentaram boa fixação ao náilon gerando assim bom aproveitamento dos sinais de hibridação.

Para a biblioteca MTB de camundongos foram amplificados até o momento para este trabalho 8448 clones, dos quais $80 \%$ foram positivos e foram finalmente selecionados para aplicar nos microarrays, 16 \% não amplificaram e 4\% apresentaram contaminação (Figura 20). A Figura 21 mostra o controle de qualidade da amplificação de parte dos clones de cDNA da biblioteca. 


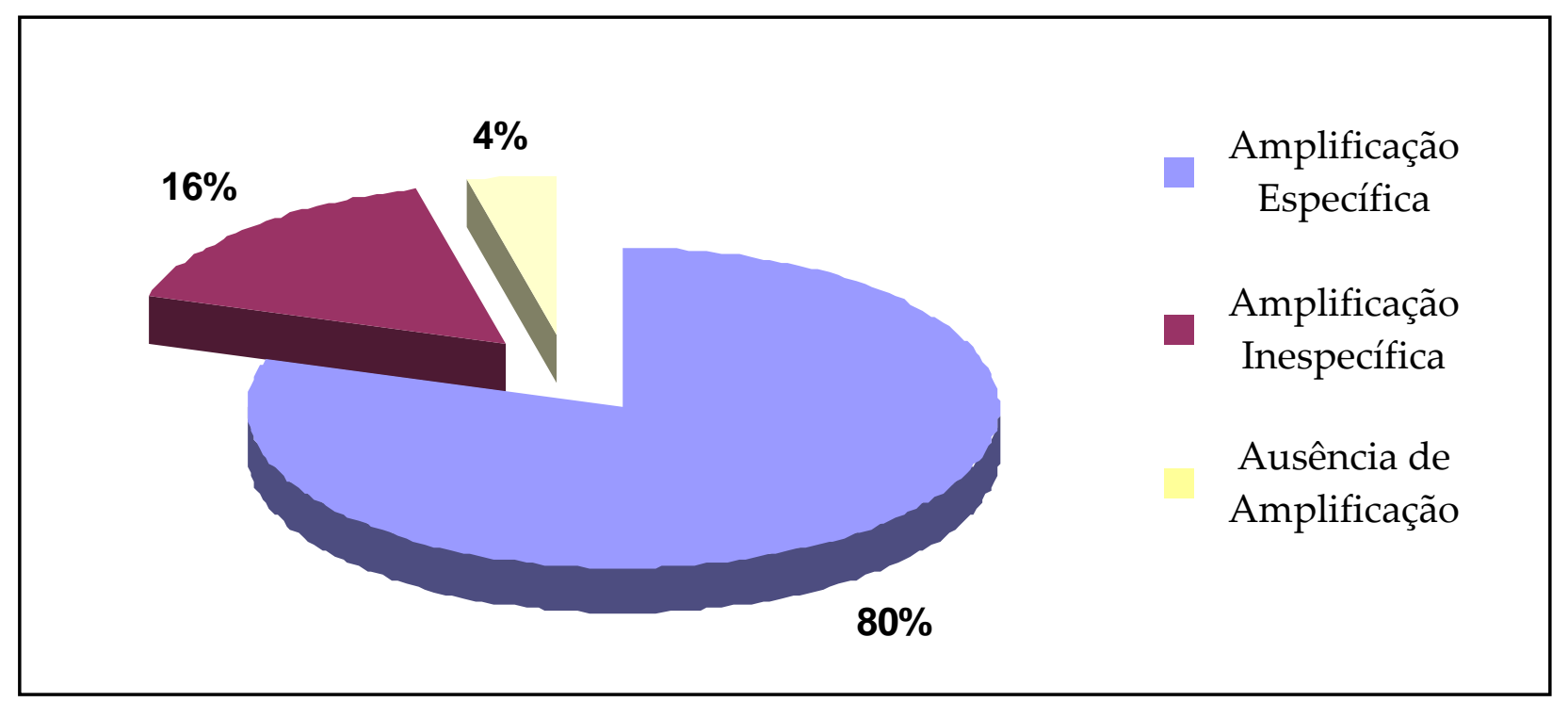

Figura 20. Representação gráfica da eficiência da amplificação por PCR dos clones de cDNA da biblioteca MTB utilizados para confecção da membrana de microarray.

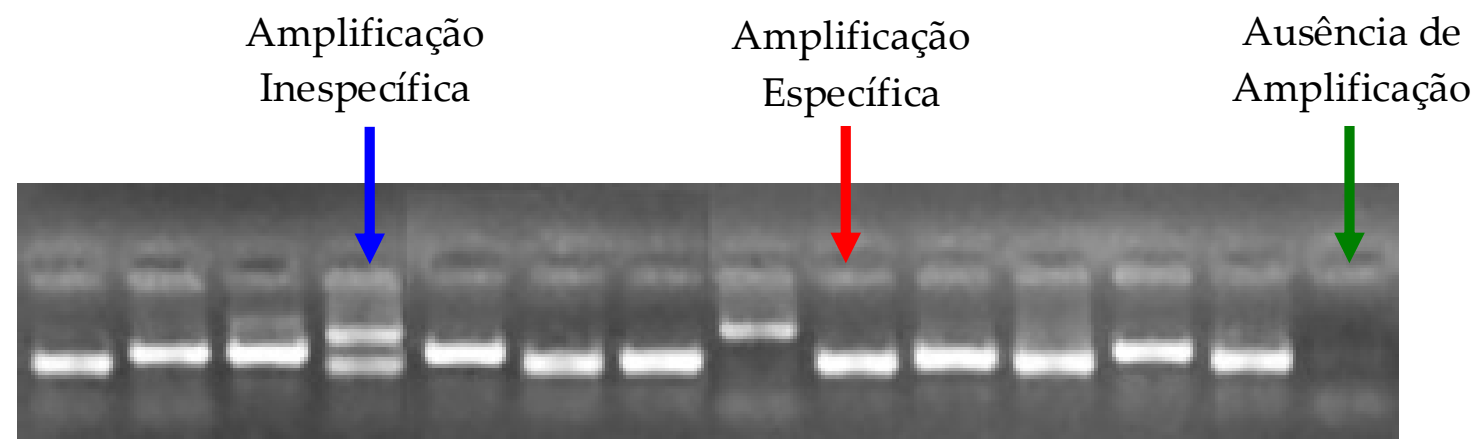

Figura 21. Avaliação das amplificações por PCR dos clones de cDNA da biblioteca MTB murina por meio de eletroforese em gel de agarose 1\%. Em destaque, clones cuja amplificação foi inespecífica, específica ou ausente. 


\subsection{DETERMINAÇÃO DA EXPRESSÃO GÊNICA PROMÍSCUA (PGE) NO TIMO}

Perfis de PGE no timo foram avaliados usando cDNA microarrays em lâminas de vidro contendo 4500 seqüências alvo (IMAGE) as quais foram hibridadas com sondas fluorescentes Cy3 ou Cy5.

A caracterização do padrão de expressão gênica no timo de camundongos Balb-c, C57Bl/6 e seus híbridos, na idade fetal quando ocorre a recombinação $\mathrm{V}(\mathrm{D}) \mathrm{J}$ de TRBV8.1, se deu quando comparados com um pool de órgãos linfóides e não linfóides, de mesma idade, o que proporcionou o conhecimento dos genes diferencialmente expressos que podem ser genes órgãos-específicos.

As Figuras 22 e 23, bem como a Tabela II (Anexo II) mostram os resultados de experimentos com cDNA microarrays, analisados com o auxílio do programa "Significance Analysis of Microarrays" (SAM) (Tusher et al., 2001), após as normalizações dos dados no programa R. Estas figuras representam gráficos de dispersão que ilustram uma comparação entre a distância relativa observada d(i) e a esperada $d_{E}$ (i) dos genes diferencialmente expressos. Os pontos localizados à direita da ordenada e acima de zero são interpretados como genes induzidos (hiperexpressos) em relação à média. Como ultrapassam o limiar $\Delta$ (distância entre as linhas oblíquas tracejadas até a linha oblíqua contínua), esses foram considerados diferencialmente expressos pelo programa SAM. Da mesma forma, os pontos à esquerda da ordenada e abaixo do ponto zero, além de serem interpretados como genes reprimidos (hipoexpressos) em relação à média, também foram diferencialmente expressos, uma vez que ultrapassaram os limites de $\Delta$.

Deve-se salientar que os genes considerados como reprimidos (hipoexpressos) foram na realidade transcritos, mas numa proporção menor do que os genes induzidos (hiperexpressos). 


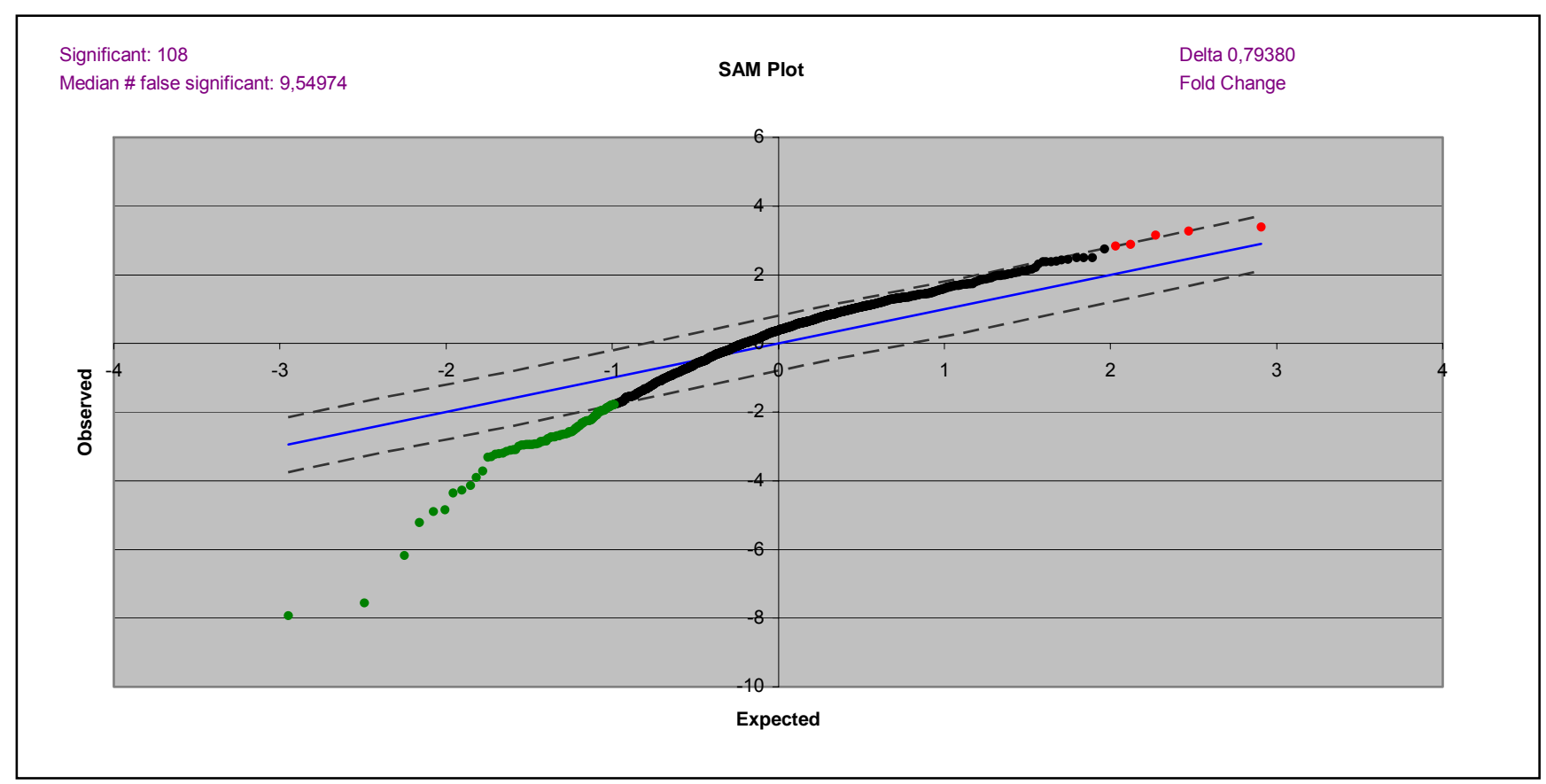

Figura 22: Genes diferencialmente expressos como mostrados pelo programa SAM. Resultados das comparação entre a distância relativa observada $d(i)$ e esperada $d_{E}(i)$ dos dados referentes a relação timo- pool de órgãos. A linha azul contínua á a região onde $\mathrm{d}(\mathrm{i})=\mathrm{d} \mathrm{E}(\mathrm{i})$. As linhas tracejadas são cortes a uma distância $\Delta$ da linha contínua. Os pontos verdes representam genes que afastaram da linha $\mathrm{d}(\mathrm{i})=$ $\mathrm{d}_{\mathrm{E}}(\mathrm{i})$ a uma distância $\langle\Delta$; já os pontos vermelhos representam genes que se afastaram da linha $\mathrm{d}(\mathrm{i})=$ $\mathrm{d}_{\mathrm{E}}(\mathrm{i})$, mas a uma distância $>\Delta$.

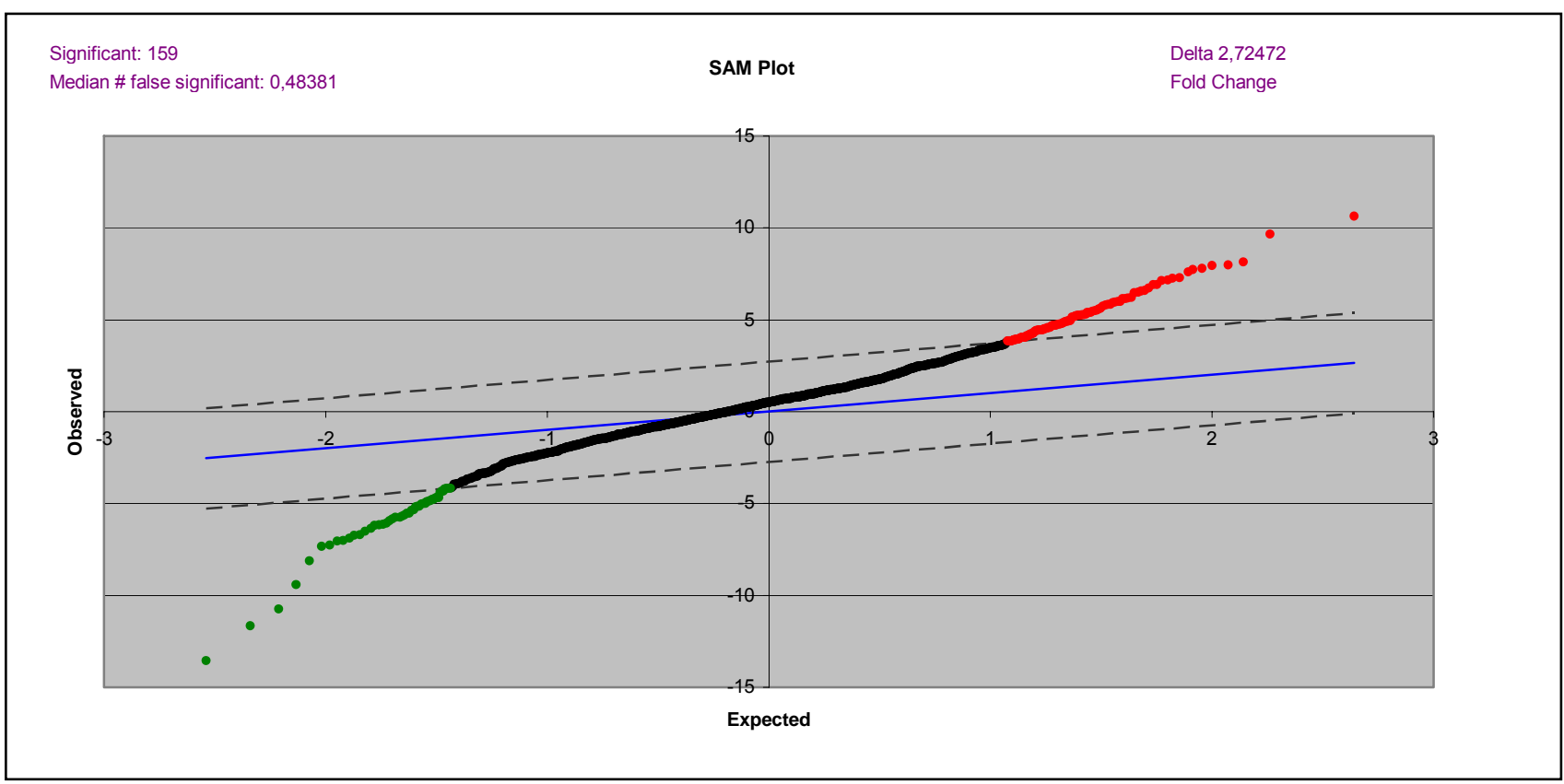

Figura 23: Genes diferencialmente expressos como mostrados pelo programa SAM. Resultados das comparação entre a distância relativa observada d(i) e esperada de(i) dos dados referentes a relação timo- pool de órgãos de camundongos híbridos (Balb-c x $\mathrm{C} 57 \mathrm{Bl} / 6) \mathrm{F}_{1}$, sendo que a linha azul contínua á a região onde $\mathrm{d}(\mathrm{i})=\mathrm{d}(\mathrm{i})$. As linhas tracejadas são cortes a uma distância $\Delta$ da linha contínua. Os pontos verdes representam genes que afastaram da linha $\mathrm{d}(\mathrm{i})=\mathrm{d}_{\mathrm{E}}(\mathrm{i})$ a uma distância $<\Delta$; já os pontos vermelhos representam genes que se afastaram da linha $d(i)=d_{E}(i)$, mas a uma distância $>\Delta$. 
A maioria das 4500 seqüências testadas apresentaram $\mathrm{d}(\mathrm{i}) \cong \mathrm{d}(\mathrm{i})$, indicando que seu perfil de expressão permaneceu inalterado. Entretanto, alguns genes se apresentaram significativamente reprimidos [71 em Balb-c, 57 em C57Bl/6 e 17 em híbridos (Balb-c x C57Bl/6)F1)] ou induzido [3 em C57Bl/6 e 70 genes em híbridos(Balb-c x C57Bl/6)F1].

A Figura 24 mostra que entre as linhagens estudadas, a indução significativa de genes é inversamente proporcional a repressão, sugerindo um papel importante para o background genético das linhagens no controle de PGE.

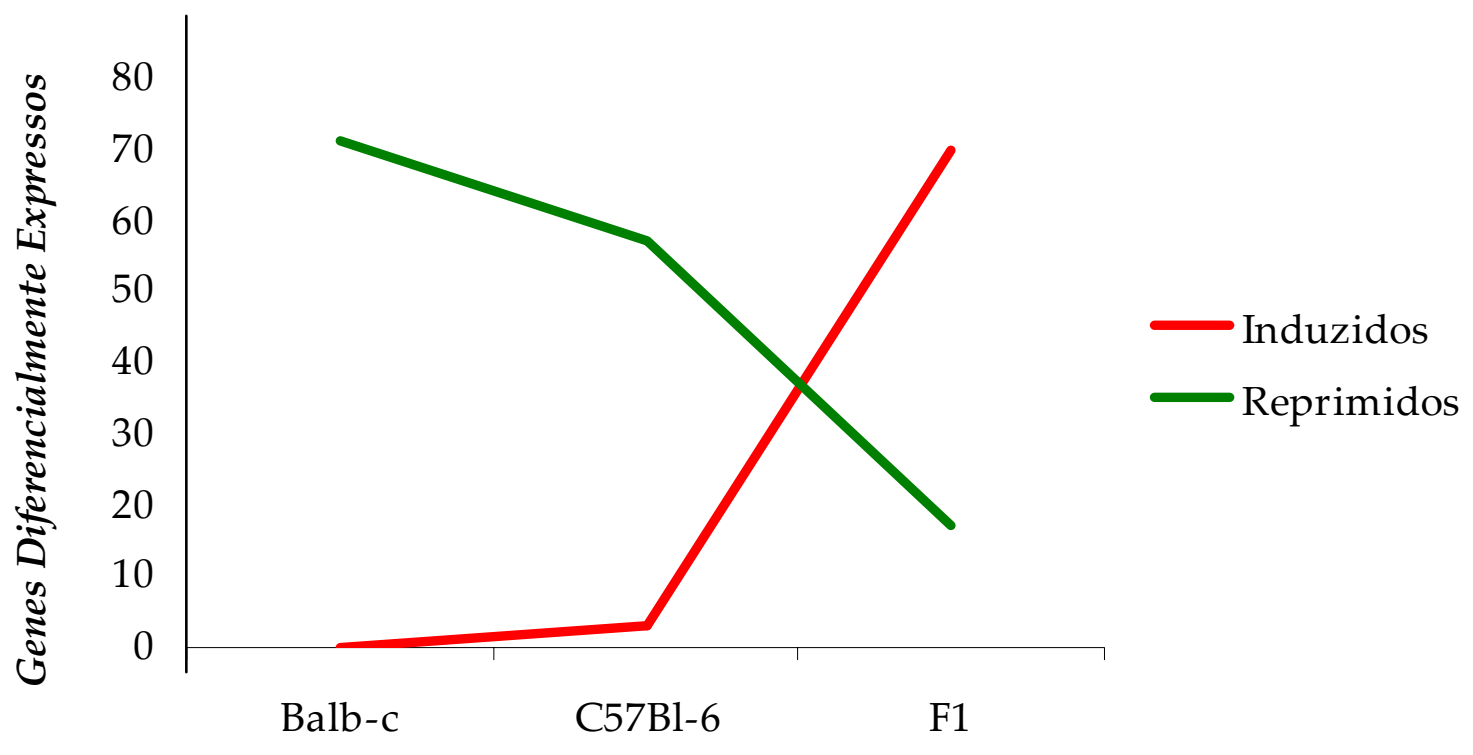

\section{Linhagens}

Figura 24. Número de genes induzidos ou reprimidos em timo fetal durante a emergência da recombinação de TRBV8.1 nas linhagens isogênicas de camundongos. F1 = (Balb-c x C57Bl/6)F1. 
A Figura 25 ilustra que os sistemas nervoso central e reprodutivo, glândulas e células-tronco em C57Bl/6 e sistemas nervoso central e reprodutivo em (Balb-c x C57Bl/6)F1 são os tecidos parenquimatosos predominantes mais representados no timo nesta fase do desenvolvimento, seguida pelo sistema linfóide. 


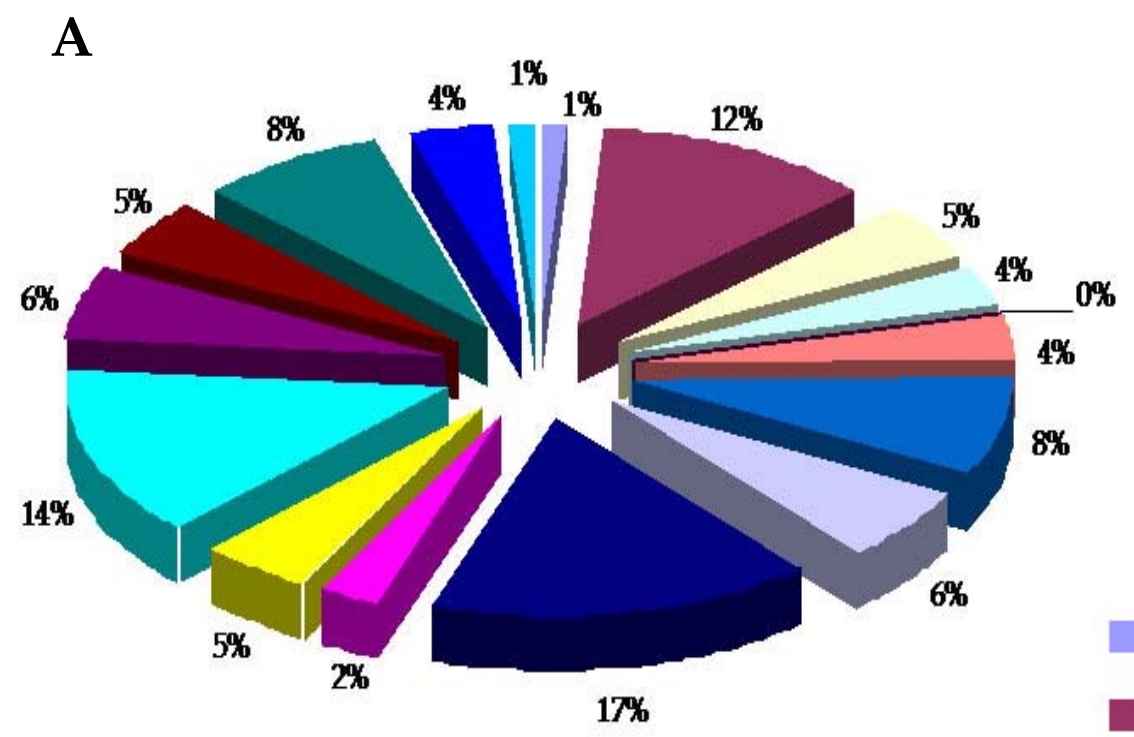

$\begin{array}{ll}\text { Circulatório } & \text { Linfóide } \\ \text { Nervoso Central } & \text { Músculos }\end{array}$

Digestivo

Nervoso Periférico

Epiderme/Pele

Reprodutor

Olhos

Respiratório

Tecido Adiposo

B

Glândulas

Órgãos Sensoriais

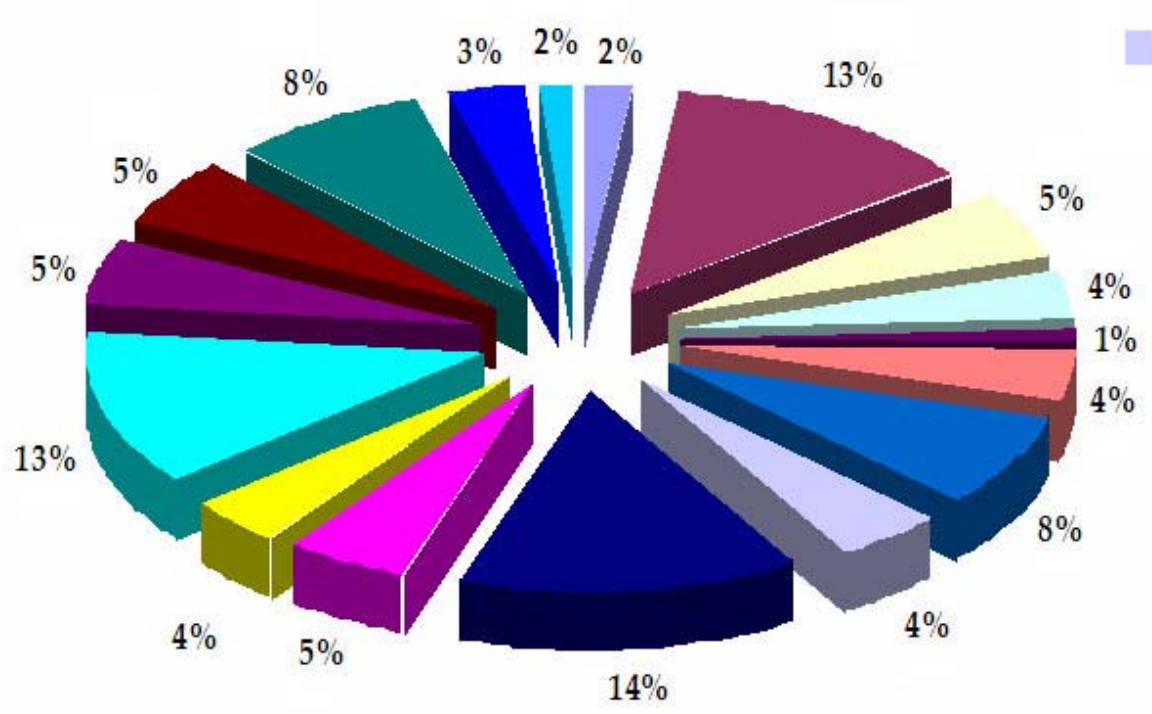

Locomotor

Stem cells

Urinário

Placenta

Figura 25. Representação da expressão gênica específica de tecidos e órgãos em timo fetal durante a emergência da recombinação de TRBV8.1. Os genes significativamente induzidos dos 4500 analisados foram anotados caracterizando a expressão promíscua, representando os antígenos tecido-específicos no timo. $25 \mathrm{~A}=\mathrm{C} 57 \mathrm{Bl} / 6,25 \mathrm{~B}=(\mathrm{Balb}-\mathrm{c} \mathrm{x}$ C57B1/6)F1. 
A distribuição genômica das seqüências significativamente moduladas (reprimidas e induzidas), ou seja, 71 em Balb-c, 60 em C57Bl/6 e 87 (Balb-c x C57Bl/6)F1, permitiu a organização coordenada de grupos cromossômicos envolvidos na PGE. A Figura 25 mostra a distribuição da freqüência dos genes reprimidos e induzidos entre cromossomos. Todos os cromossomos, exceto $\mathrm{Y}$, abrigam genes diferencialmente expressos, com distribuição ligeiramente concentrada nos cromossomos 2, 5, 11, 13, 17 e 19 para os genes reprimidos em Balb-c, nos cromossomos 2, 3, 6, 9 e 11 para reprimidos e 11, 13 e 17 para induzido em C57Bl/6, nos cromossomos 2, 7, 9, 13 e 15 para reprimidos e nos cromossomos 2, 4, 5, 7, 10, 11, 18 e 19 para os genes induzidos nos híbridos (Balb-c x C57Bl/6)F1. 

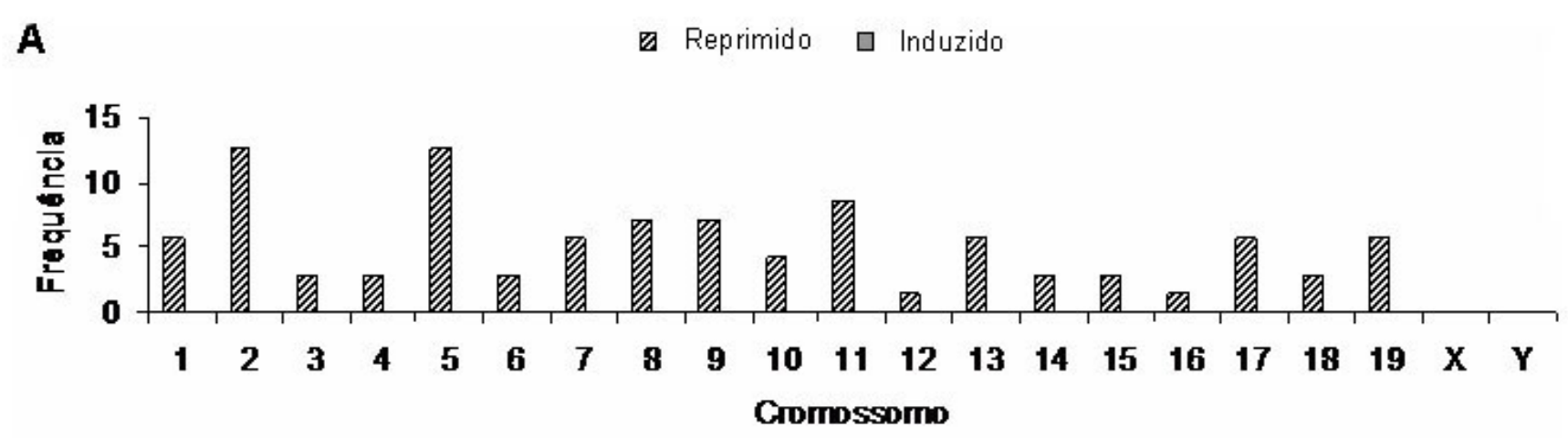

B

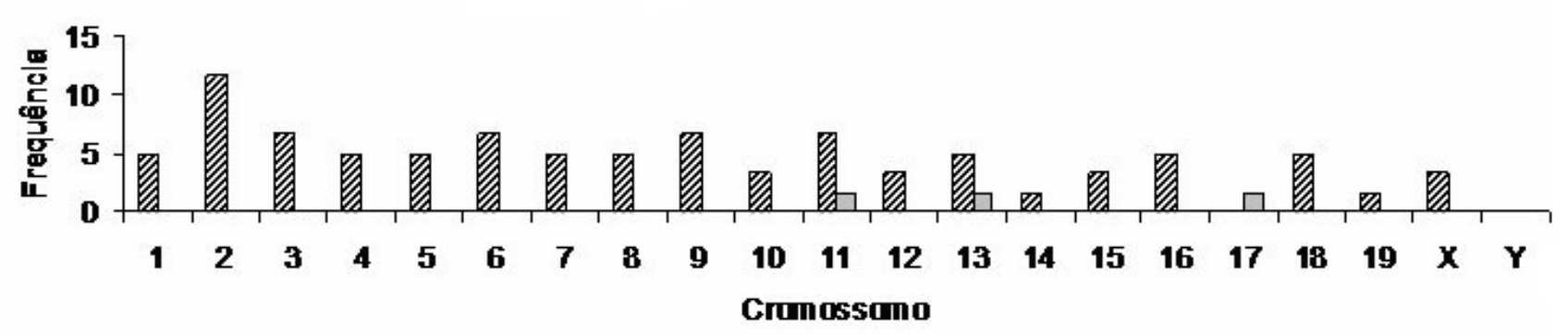

C

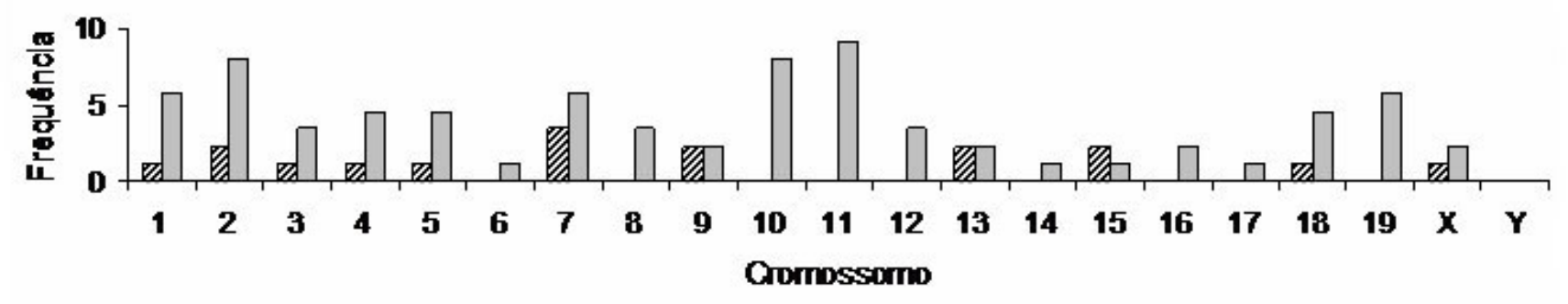

Figura 26. Distribuição cromossômica dos genes reprimidos e induzidos no timo fetal durante a emergência da recombinação TRBV8.1 entre linhagens isogênicas de camundongos $24 \mathrm{~A}=\mathrm{Balb}-\mathrm{c}, 24 \mathrm{~B}=$ $\mathrm{C} 57 \mathrm{Bl} / 6,24 \mathrm{C}=(\mathrm{Balb}-\mathrm{c} \times \mathrm{C} 57 \mathrm{Bl} / 6) \mathrm{F}_{1}$.

\subsection{DETERMINAÇÃO DE ASSINATURAS DE EXPRESSÃO GÊNICA DOS TIPOS CELULARES ENCONTRADOS NO TIMO}

Todas as amostras foram hibridadas a um cDNA microarray em náilon contendo 8750 seqüências alvo de diferentes bibliotecas murinas preparadas de embrião, timo, linfonodo, e de baço. Após a normalização e filtragem dos 
dados, 6936 seqüências foram mantidas para a análise. Agrupamento hierárquico foi usado para ordenar genes de acordo com a variação da expressão entre as amostras. O mesmo método foi aplicado para grupos de amostras experimentais de acordo com sua similaridade transcricional. Os resultados estão apresentados na Figura 27.

Neste trabalho definimos as assinaturas de expressão (também denominados de assinaturas de hibridação) em primeiro lugar observando o agrupamento hierárquico (dendrograma) das amostras (tipos de células ou tecidos). Depois observamos a composição do conjunto de genes diferencialmente expressos pela inspeção visual do "heat map" colorido, o qual nos permite identificar cada um dos genes induzidos e reprimidos. Finalmente, assinaturas moleculares específicas foram associadas aos respectivos camundongos $\left(\operatorname{Rag} 1^{\circ}, \mathrm{Lat}^{\circ}, \mathrm{CD} 3 \mathrm{e}^{\circ}, \mathrm{TCR} \alpha^{\circ}, \operatorname{Relb}^{\circ}\right.$ e WT) (Figura 28). 


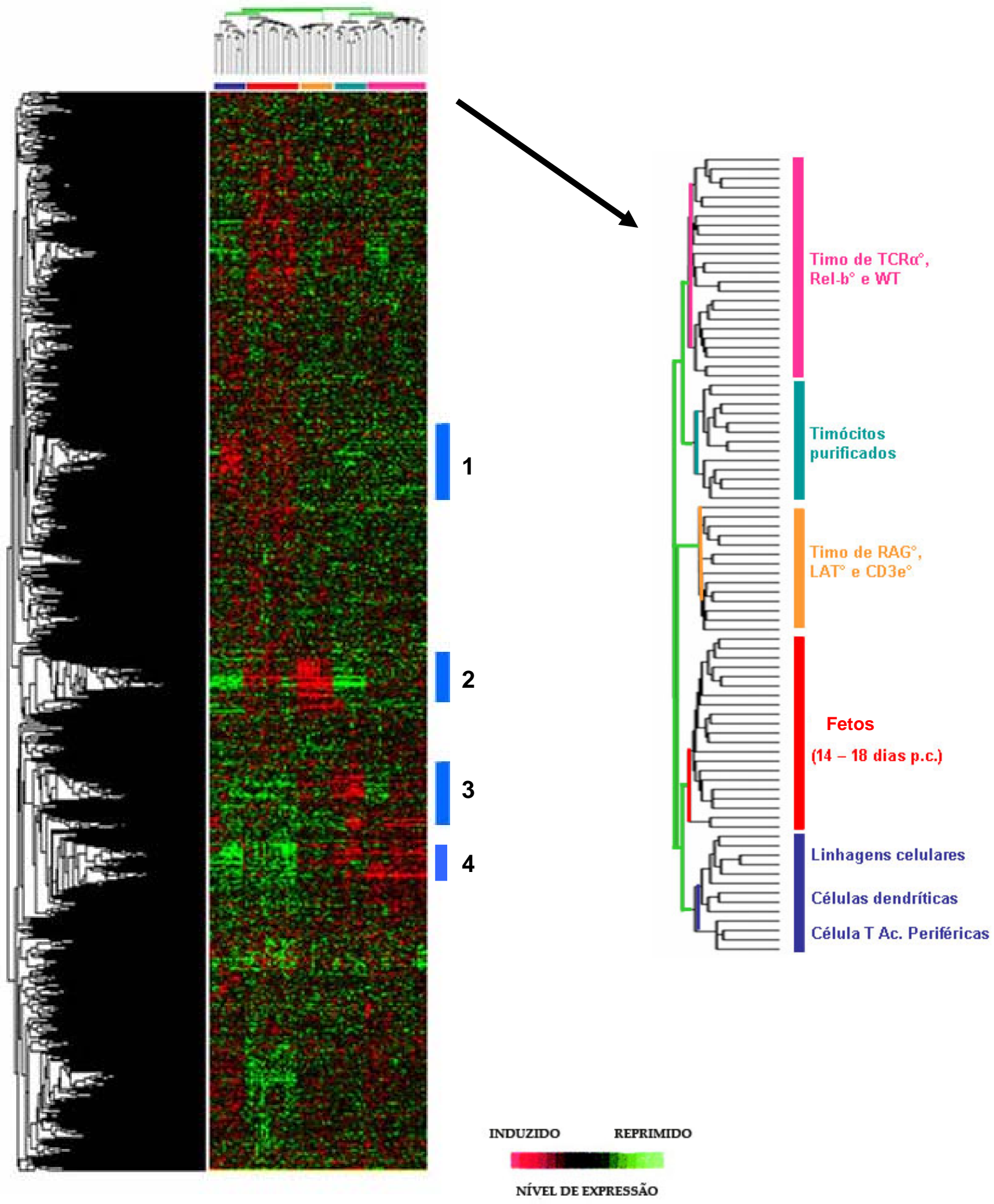

Figura 27. Agrupamento hierárquico baseado nos dados de expressão gênica obtidos de 86 variáveis, todas relacionadas com o timo e/ou desenvolvimento de timócitos. Três assinaturas de expressão diferentes foram assim identificadas: 1) Genes definindo assinatura de macrófagos; 2)Genes definindo assinatura de estroma tímico; 3) Genes definindo assinatura de timócitos e 4)Genes definindo assinatura de timócitos em maturação. Em destaque, ampliação do dendrograma das amostras. 
A Figura 28 mostra uma reorganização dos dados para que possamos ter uma visão mais clara das assinaturas de expressão dos principais componentes celulares tímicos considerando as amostras das quais as preparações de RNA total foram extraídas.

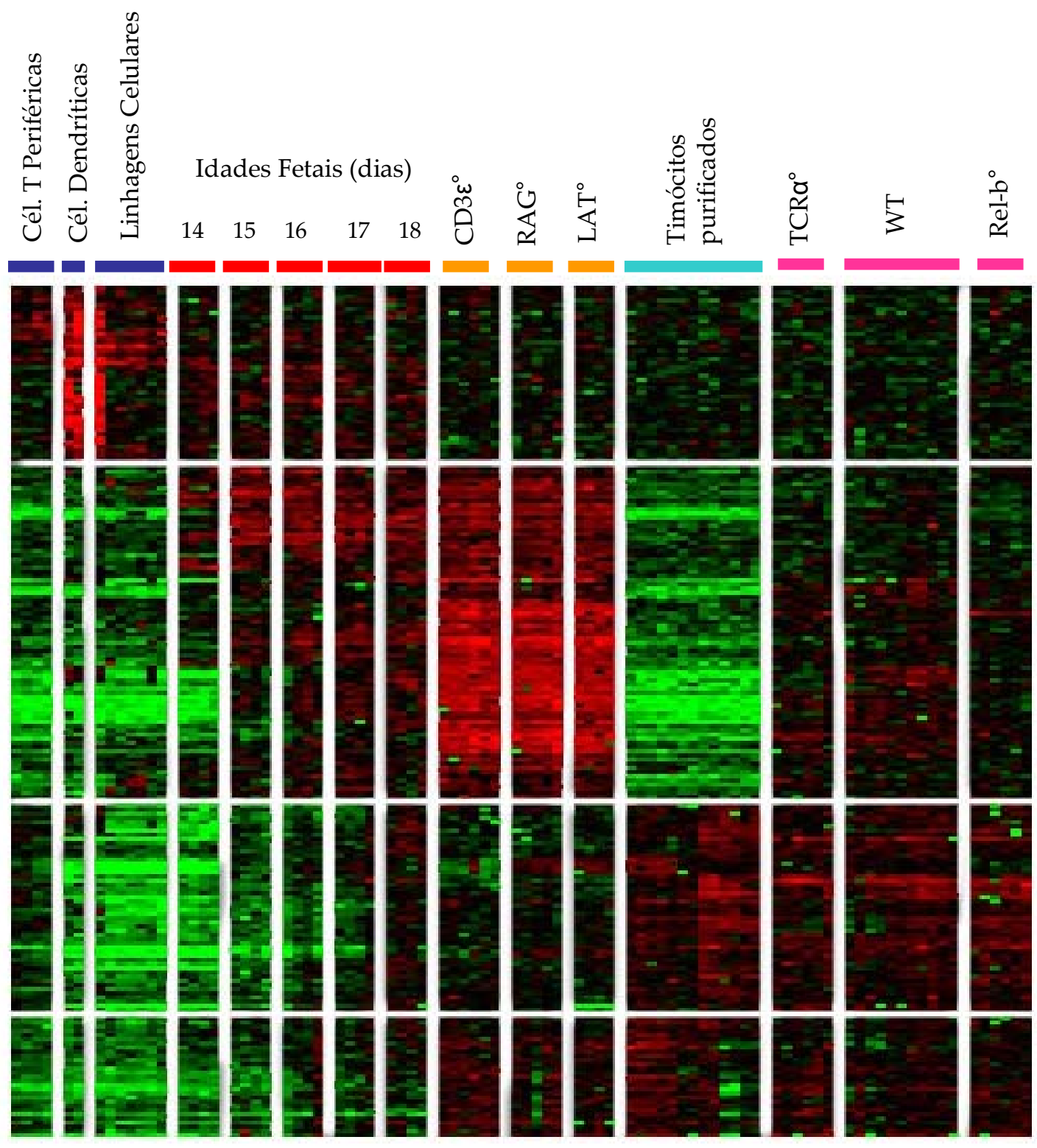

1) MACRÓFAGO

2) ESTROMA TÍMICO

3) TIMÓCITO

4) TIMÓCITO EM MATURAÇÃO

Figura 28. Dissecção molecular virtual do timo. Identificação de assinaturas moleculares de expressão gênica que caracterizam macrófagos, estroma tímico, timócitos e timócitos em maturação. 
Os genes que definem a assinatura de macrófagos (agrupamento 1), assim como sua localização cromossômica e suas respectivas funções estão apresentados na Tabela III.

Tabela III. Genes com expressão diferencial que definem a assinatura de macrófagos.

\begin{tabular}{|c|c|c|c|c|}
\hline $\mathrm{Mm}$ & Símbolo & Nome do gene & Crom. & Função \\
\hline Mm.3000 & P2ry2 & $\begin{array}{l}\text { P2Y2 purinergic receptor P2Y, G- } \\
\text { protein coupled } 2\end{array}$ & 7 & $\begin{array}{c}\text { Via de sinalização acoplada a } \\
\text { proteína } G\end{array}$ \\
\hline Mm.164948 & Evi2a & $\begin{array}{l}\text { Evi-2 Ecotropic viral integration site } \\
2 \mathrm{a}\end{array}$ & 11 & \\
\hline Mm.306511 & Insl6 & $\begin{array}{l}\text { RIF1Insulin-like } 6 \text { | | relaxin/insulin- } \\
\text { like factor } 1\end{array}$ & 19 & Processo fisiológico \\
\hline Mm.217787 & Atp6v1a & $\begin{array}{l}\text { Atp6v1a1 I I ATPase, } \mathrm{H}+ \\
\text { transporting, lysosomal V1 subunit } \\
\text { A I I ATPase, H+ transporting, V1 } \\
\text { subunit A, isoform } 1\end{array}$ & 16 & Biossíntese de ATP \\
\hline Mm.2706 & Atf3 & $\begin{array}{l}\text { LRG-21 Activating transcription } \\
\text { factor } 3\end{array}$ & 1 & Atividade repressor transcricional \\
\hline Mm.276018 & Trib3 & $\begin{array}{l}\text { SKIP3 | I Nipk | | Ifld2 | | tribbles } \\
\text { homolog } 3 \text { (Drosophila) }\end{array}$ & 2 & $\begin{array}{c}\text { Regulação da } \\
\text { transcrição/apoptose/atividade } \\
\text { quinase }\end{array}$ \\
\hline Mm.1282 & $\mathrm{Ccl} 3$ & $\begin{array}{l}\text { Scya3 | I LD78alpha I I G0S19- } \\
\text { 1 I IMIP-1alpha I I MIP1- } \\
\text { (a) I I Mip1a I I MIP1-alpha I I MIP-1 } \\
\text { alpha I I macrophage inflammatory } \\
\text { protein-1alpha I I chemokine (C-C } \\
\text { motif) ligand } 3\end{array}$ & 11 & $\begin{array}{l}\text { Atividade quimiocina/citocina - } \\
\text { quimiotaxia/ transdução de } \\
\text { sinal/resposta a inflamação }\end{array}$ \\
\hline Mm.23585 & Prlpm & PLP-M prolactin-like protein $\mathrm{M}$ & 13 & Atividade citocina \\
\hline Mm.1282 & $\mathrm{Ccl} 3$ & $\begin{array}{l}\text { I | | IScya3 | I LD78alpha | I G0S19- } \\
\text { 1 I I MIP-1alpha I I MIP1- } \\
\text { (a) I I Mip1a I I MIP1-alpha I I MIP-1 } \\
\text { alpha I I macrophage inflammatory } \\
\text { protein-1alpha I I chemokine (C-C } \\
\text { motif) ligand } 3\end{array}$ & 11 & $\begin{array}{l}\text { Atividade quimiocina/citocina - } \\
\text { quimiotaxia/ transdução de } \\
\text { sinal/resposta a inflamação }\end{array}$ \\
\hline Mm.210676 & Cd9 & Tspan29I ICD9 antigen & 6 & Adesão celular \\
\hline Mm.18626 & Capg & $\begin{array}{l}\text { I mbh1 | IgCap39 | I Capping protein } \\
\text { (actin filament), gelsolin-like }\end{array}$ & 6 & Ligante de actina \\
\hline Mm.7729 & Aldoc & $\begin{array}{l}\text { Aldo3 | Izebrin II I I Aldolase } \\
\text { CI Ialdolase 3, C isoform }\end{array}$ & 11 & Glicólise \\
\hline Mm.288474 & Spp1 & 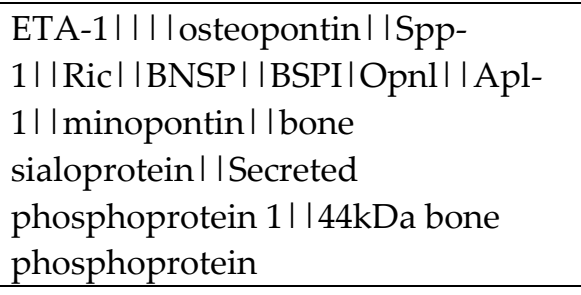 & 5 & Adesão celular/atividade citocina \\
\hline
\end{tabular}




\begin{tabular}{|c|c|c|c|c|}
\hline Mm.66853 & Iws1 & $\begin{array}{l}\text { 1700069O15Rik | I RIKEN cDNA } \\
\text { 1700069O15 gene I I IWS1 homolog } \\
\text { (S. cerevisiae) }\end{array}$ & 18 & Transporte de elétrons \\
\hline Mm.291485 & Tarbp2 & $\begin{array}{l}\text { Prbp I ITAR (HIV) RNA binding } \\
\text { protein } 2\end{array}$ & 15 & Ligante de RNA \\
\hline Mm.276389 & Hmox1 & $\begin{array}{l}\text { D8Wsu38e I I HO-1 I I Hsp32 I I heme } \\
\text { oxygenase } 1 \text { I I Heme oxygenase } \\
\text { (decycling) } 1\end{array}$ & 8 & Atividade oxirredutase \\
\hline Mm.25613 & Ier3 & $\begin{array}{l}\text { IEX-1 | | gly96 | I cI-3 | I Immediate } \\
\text { early response } 3 \text { | I cAMP inducible } \\
\text { gene } 3\end{array}$ & 17 & \\
\hline Mm.292690 & Zfp30 & | |Zfp30| |Zinc finger protein 30 & 7 & Ligante de DNA \\
\hline Mm.191892 & Herc3 & | |Herc3| | hect domain and RLD 3 & 6 & \\
\hline Mm.4406 & Mmp9 & $\begin{array}{l}\text { Clg4b | |B/MMP9| | Mmp9 | | Gelatin } \\
\text { ase B | |92kDa gelatinase | | Gel } \\
\mathrm{B} \mid \text { | Matrix metallopeptidase } \\
\text { 9| | matrix metalloproteinase } \\
\text { 9||92kDa type IV collagenase }\end{array}$ & 2 & $\begin{array}{c}\text { Catabolismo de } \\
\text { colágeno/proteólise/peptidase }\end{array}$ \\
\hline Mm.22673 & Fcer1g & $\begin{array}{l}\text { FcR[g] | | Ly-50 | | Fce1g | | FcR- } \\
\text { gamma | | Fc receptor, IgE, high } \\
\text { affinity I, gamma polypeptide }\end{array}$ & 1 & Receptor para ligante de IgE \\
\hline Mm.22119 & Fcgr3 & $\begin{array}{l}\text { FcgammaRIII | I CD16 I I Fcg receptor } \\
\text { III I IFc receptor, IgG, low affinity III }\end{array}$ & 1 & Receptor para ligante de IgG \\
\hline Mm.137 & Ccl6 & $\begin{array}{l}\text { I | | |c10 | MRP- } \\
1 \text { | IScya6 | I chemokine (C-C motif) } \\
\text { ligand } 6\end{array}$ & 11 & $\begin{array}{l}\text { Atividade quimiocina/citocina - } \\
\text { quimiotaxia/transdução de sinal }\end{array}$ \\
\hline Mm.137 & Ccl6 & $\begin{array}{l}\text { I | | |c10 | | Ccl6 | IMRP- } \\
1 \text { | IScya6 | I chemokine (C-C motif) } \\
\text { ligand } 6\end{array}$ & 11 & $\begin{array}{l}\text { Atividade quimiocina/citocina - } \\
\text { quimiotaxia/ transdução de sinal }\end{array}$ \\
\hline Mm.15969 & Adam8 & $\begin{array}{l}\text { I | | |CD156a | IMS2 | | A disintegrin } \\
\text { and metallopeptidase domain } 8 \mid \text { | a } \\
\text { disintegrin and metalloprotease } \\
\text { domain } 8\end{array}$ & 7 & $\begin{array}{l}\text { Adesão célula-célula/Via de } \\
\text { sinalização mediada por integrina }\end{array}$ \\
\hline Mm.332490 & Cxcl4 & $\begin{array}{l}\text { I| | IScyb4| | Pf4| I chemokine (C-X- } \\
\text { C motif) ligand } 4\end{array}$ & 5 & $\begin{array}{c}\text { Atividade quimiocina/citocina - } \\
\text { quimiotaxia }\end{array}$ \\
\hline Mm.271839 & Tyki & $\begin{array}{l}\text { TDKI I I thymidylate kinase family } \\
\text { LPS-inducible member }\end{array}$ & 12 & Atividade quinase/transferase \\
\hline Mm.23462 & Emilin2 & $\begin{array}{l}\text { basilin | |FOAP-10 | | Elastin } \\
\text { microfibril interfacer } 2\end{array}$ & 17 & Adesão celular \\
\hline Mm.330524 & $\operatorname{Igsf} 4 b$ & $\begin{array}{l}\text { | | | | BIgR | | Necl1 | | Tsll1 | | immuno } \\
\text { globulin superfamily, member 4B }\end{array}$ & 1 & \\
\hline Mm.34408 & Gp49a & | |Gp49a | Iglycoprotein 49 A & 10 & \\
\hline Mm.34408 & Gp49a & | | Gp49a | | glycoprotein 49 A & 10 & \\
\hline Mm.1302 & Sfpi1 & $\begin{array}{l}\text { I | Dis1 | ITfpu.1||Spi- } \\
1 \text { |Tcfpu1| ISfpi-1||SFFV proviral } \\
\text { integration } 1\end{array}$ & 2 & Diferenciação de macrófago \\
\hline Mm.54174 & Cias1 & $\begin{array}{l}\text { | | | | Pypaf1 | | NALP3 | | AII/AVP | | c } \\
\text { ryopyrin | | Cold autoinflammatory } \\
\text { syndrome } 1 \text { homolog (human) }\end{array}$ & 11 & Apoptose \\
\hline Mm.3460 & Cd14 & | |Cd14 | |CD14 antigen & 18 & Resposta inflamatória \\
\hline Mm.15969 & Adam8 & | | | |CD156a | | MS2 | | A disintegrin & 7 & Adesão célula-célula/Via de \\
\hline
\end{tabular}




\begin{tabular}{|c|c|c|c|c|}
\hline & & $\begin{array}{l}\text { and metallopeptidase domain } 8 \mid \text { I a } \\
\text { disintegrin and metalloprotease } \\
\text { domain } 8\end{array}$ & & sinalização mediada por integrina \\
\hline Mm.210676 & $\mathrm{Cd} 9$ & | | Tspan29| |CD9 antigen & 6 & Adesão celular \\
\hline Mm.95452 & Naglu & $\begin{array}{l}\text { I I Naglu | I alpha-N- } \\
\text { acetylglucosaminidase (Sanfilippo } \\
\text { disease IIIB) }\end{array}$ & 11 & Atividade oxirredutase \\
\hline Mm.207052 & Atp6v0b & $\begin{array}{l}\text { I | | | Atp6f | | VMA16 | | ATPase, H+ } \\
\text { transporting, V0 subunit } \\
\text { B | | ATPase, H+ transporting, } \\
\text { lysosomal V0 subunit B }\end{array}$ & 4 & Biossíntese de ATP \\
\hline Mm.21288 & Ell2 & $\begin{array}{l}\text { | | Ell2 | | elongation factor RNA } \\
\text { polymerase II } 2\end{array}$ & 13 & Fator de elongação positiva \\
\hline
\end{tabular}

$M m=$ UniGene Acc. Number

Crom. = localização cromossômica

Todos os genes que definem a assinatura de estroma tímico, assim como sua localização cromossômica e suas respectivas funções estão apresentados na Tabela IV. 
Tabela IV. Genes com expressão diferencial que definem a assinatura de estroma tímico

\begin{tabular}{|c|c|c|c|c|}
\hline Mm & Símbolo & Nome do gene & Crom. & Função \\
\hline Mm.37214 & Trf & Transferrin||HP||Tfn||Cd176 & 9 & Vesícula endocítica \\
\hline Mm.16769 & Tegt & Tegt | I Testis enhanced gene transcript & 15 & Apoptose \\
\hline Mm.5021 & Ddr1 & $\begin{array}{l}\text { CD167a | |PTK3A I ICak I I Discoidin } \\
\text { domain receptor family, member } 1\end{array}$ & 17 & $\begin{array}{l}\text { Adesão celular/Atividade } \\
\text { quinase }\end{array}$ \\
\hline Mm.315502 & Pax1 & $\begin{array}{l}\text { wt | hbs | I hunchback | I wavy } \\
\text { tail | | Paired box gene } 1\end{array}$ & 2 & Regulação da Transcrição \\
\hline Mm.302399 & Krt2-6a & $\begin{array}{l}\text { MK6a | IKrt2-6c I ImK6[a] | I60kDa } \\
\text { keratin I IKeratin complex 2, basic, } \\
\text { gene 6a }\end{array}$ & 15 & $\begin{array}{c}\text { Atividade molecular } \\
\text { estrutural }\end{array}$ \\
\hline Mm.22144 & Copz2 & $\begin{array}{l}\text { Inonclathrin coat protein zeta2- } \\
\text { COPIICoatomer protein complex, } \\
\text { subunit zeta } 2\end{array}$ & 11 & $\begin{array}{l}\text { Proliferação celular/regulação } \\
\text { negativa da } \\
\text { transcrição/transdução de sinal }\end{array}$ \\
\hline Mm.22147 & Gtpbp2 & Gtpbp2 I IGTP binding protein 2 & 17 & $\begin{array}{c}\text { Fator de elongação/ligante } \\
\text { GTP } \\
\end{array}$ \\
\hline Mm.153272 & Tsc22d1 & $\begin{array}{l}\text { Tgfb1i4 I I TSC22 domain family, } \\
\text { member } 1 \text { I I transforming growth } \\
\text { factor beta } 1 \text { induced transcript } 4\end{array}$ & 14 & Regulação da Transcrição \\
\hline Mm.41868 & $\begin{array}{l}\text { 2810405K02 } \\
\text { Rik }\end{array}$ & $\begin{array}{l}\text { | | 2810405K02Rik | | RIKEN cDNA } \\
\text { 2810405K02 gene }\end{array}$ & 4 & \\
\hline Mm.235547 & Pdk4 & $\begin{array}{l}\text { Pyruvate dehydrogenase kinase, } \\
\text { isoenzyme } 4\end{array}$ & 6 & Atividade tirosina quinase \\
\hline Mm.14046 & Krt1-17 & $\begin{array}{l}\text { | K17 | | keratin 17 | | Keratin complex } 1 \text {, } \\
\text { acidic, gene } 17\end{array}$ & 11 & $\begin{array}{c}\text { Atividade molecular } \\
\text { estrutural }\end{array}$ \\
\hline Mm.275572 & Dmrt2 & $\begin{array}{l}\text { Terra I I Doublesex and mab-3 related } \\
\text { transcription factor } 2\end{array}$ & 19 & Regulação da Transcrição \\
\hline Mm.4496 & Foxn1 & $\begin{array}{l}\text { whn | |Hfh11 | |D11Bhm185e | | forkhe } \\
\text { ad box N1 }\end{array}$ & 11 & $\begin{array}{c}\text { Diferenciação de } \\
\text { queratinócitos/ Regulação da } \\
\text { Transcrição }\end{array}$ \\
\hline Mm.29581 & Hey1 & $\begin{array}{l}\text { hesr- } \\
1 \text { IIHerp2 I IHRT1 I | Hairy/E(spl)- } \\
\text { related with YRPW motif } \\
\text { 1। Ihairy/enhancer-of-split related } \\
\text { with YRPW motif } 1\end{array}$ & 3 & Regulação da Transcrição \\
\hline Mm.44207 & Syap1 & Syap1IISynapse associated protein 1 & $X$ & \\
\hline Mm.78875 & Cdc3711 & $\begin{array}{l}\text { Harc I I Hsp90-associating relative of } \\
\text { Cdc37 I I cell division cycle } 37 \\
\text { homolog (S. cerevisiae)-like } 1\end{array}$ & 19 & Regulação do ciclo celular \\
\hline Mm.44482 & Sfn & $\begin{array}{l}\text { Ywhas | I MME1 | IStratifin | |14-3-3 } \\
\text { sigma }\end{array}$ & 4 & Regulação do ciclo celular \\
\hline Mm.25779 & Sf3a3 & $60 \mathrm{kDa} \mid \mathrm{ISplicing}$ factor $3 \mathrm{a}$, subunit 3 & 4 & Splicing RNAm \\
\hline Mm.20522 & Lancl1 & $\begin{array}{l}\text { p40 I I Gpr69a I I LanC-like protein } \\
\text { 1 I I LanC (bacterial lantibiotic } \\
\text { synthetase component C)-like } 1\end{array}$ & 1 & $\begin{array}{c}\text { Receptor acoplado a proteína } \\
\text { G }\end{array}$ \\
\hline Mm.787 & Psmb10 & $\begin{array}{l}\text { Mecl1 I I Proteasome (prosome, } \\
\text { macropain) subunit, beta type } 10\end{array}$ & 8 & $\begin{array}{c}\text { Atividade } \\
\text { endopeptidase/hidrolase } \\
\end{array}$ \\
\hline Mm.3374 & Efnb1 & $\begin{array}{l}\text { Stra1 | ICek5-L I I EFL-3 | IElk- } \\
\text { L I IEpl2 | LERK- } \\
\text { 2 I IEplg2 | ILerk2 | | ephrin B1 | ICek }\end{array}$ & $x$ & $\begin{array}{c}\text { Diferenciação } \\
\text { celular/Regulação positiva na } \\
\text { proliferação de célula T }\end{array}$ \\
\hline
\end{tabular}




\begin{tabular}{|c|c|c|c|c|}
\hline & & ligand & & \\
\hline Mm.281691 & Sfrp1 & $\begin{array}{l}\text { sFRP-1| ISecreted frizzled-related } \\
\text { sequence protein } 1\end{array}$ & 8 & $\begin{array}{l}\text { Receptor da via de sinalização } \\
\text { Wnt/Diferenciação celular }\end{array}$ \\
\hline Mm.4657 & Apba2 & $\begin{array}{l}\text { X11-like I IX11L I lamyloid beta (A4) } \\
\text { precursor protein-binding, family A, } \\
\text { member 2 I lamyloid beta (A4) } \\
\text { precursor protein-binding, family A, } \\
\text { member } 2\end{array}$ & 7 & Transporte de proteína \\
\hline Mm.2436 & Bhlhb2 & 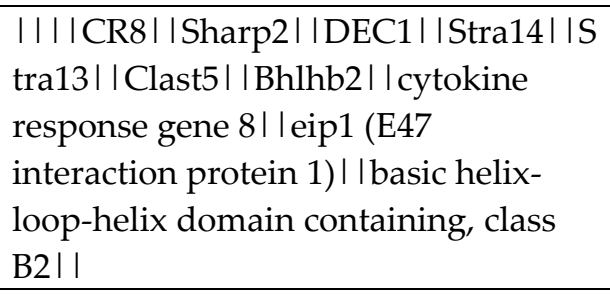 & 6 & $\begin{array}{l}\text { Atividade repressora da } \\
\text { transcrição }\end{array}$ \\
\hline Mm.57174 & Pstpip2 & $\begin{array}{l}\text { | | Pstpip2 | | Proline-serine-threonine } \\
\text { phosphatase-interacting protein } 2 \text { | | }\end{array}$ & 18 & Citoesqueleto \\
\hline Mm.2570 & $\mathrm{C} 1 \mathrm{qb}$ & $\begin{array}{l}\text { I |C1qb | |Complement component } 1 \text {, } \\
\text { q subcomponent, beta polypeptidel| }\end{array}$ & 4 & $\begin{array}{c}\text { Ativação do } \\
\text { complemento/resposta imune }\end{array}$ \\
\hline Mm.35009 & Gpr27 & $\begin{array}{l}\text { I|Gpr27 | IG protein-coupled receptor } \\
27||\end{array}$ & 6 & $\begin{array}{c}\text { Transdução de sinal/ Receptor } \\
\text { acoplado a proteína G }\end{array}$ \\
\hline Mm.305152 & Apoe & I|Apoe I I apolipoprotein E I I & 7 & Metabolismo lipoprotéico \\
\hline Mm.2570 & $\mathrm{C} 1 \mathrm{qb}$ & $\begin{array}{l}\text { I |C1qb | |Complement component } 1 \text {, } \\
\text { q subcomponent, beta polypeptide I }\end{array}$ & 4 & $\begin{array}{c}\text { Ativação do } \\
\text { complemento/resposta imune }\end{array}$ \\
\hline Mm.1569 & Casp4 & $\begin{array}{l}\text { I I Casp4 | I Casp11 | I caspase 11, } \\
\text { apoptosis-related cysteine } \\
\text { protease I I Caspase } 4 \text {, apoptosis- } \\
\text { related cysteine peptidase | I }\end{array}$ & 9 & $\begin{array}{c}\text { Indução de } \\
\text { apoptose/atividade caspase }\end{array}$ \\
\hline Mm.2074 & Ly75 & $\begin{array}{l}\text { I I I ICD205 I IDEC- } \\
205 \text { | ILy75 | I Lymphocyte antigen } \\
75 \text { | | }\end{array}$ & 2 & $\begin{array}{c}\text { Atividade receptor/resposta } \\
\text { defensiva }\end{array}$ \\
\hline Mm.2074 & Ly75 & $\begin{array}{l}\text { I I I ICD205 I IDEC- } \\
205 \text { | ILy75 | I Lymphocyte antigen } \\
75 \text { | I }\end{array}$ & 2 & $\begin{array}{l}\text { Atividade receptor/resposta } \\
\text { defensiva }\end{array}$ \\
\hline Mm.300 & Car3 & $\begin{array}{l}\text { | | Car3 | | Car-3 | |Carbonic anhydrase } \\
\text { 3| | }\end{array}$ & 3 & Atividade liase \\
\hline Mm.390411 & Stxbp4 & $\begin{array}{l}\text { | ISynip | IStxbp4 | ISyntaxin binding } \\
\text { protein } 4 \text { | | }\end{array}$ & 11 & $\begin{array}{c}\text { Cascata de sinalização } \\
\text { intracelular }\end{array}$ \\
\hline Mm.284433 & Tscot & $\begin{array}{l}\text { I I | Ly110 | ITSO- } \\
\text { 1C12| | Tscot | I Thymic stromal } \\
\text { cotransporter | I }\end{array}$ & 4 & $\begin{array}{c}\text { Transporte de } \\
\text { tetraciclina/superfície celular }\end{array}$ \\
\hline Mm.6105 & Pltp & $\begin{array}{l}\text { | | Pltp | | Phospholipid transfer } \\
\text { protein | | }\end{array}$ & 2 & Transporte de lipídio \\
\hline Mm.22479 & Krt18 & $\begin{array}{l}\text { | | Krt1-18| | Krt18| | Keratin } \\
18 \mid \text { | keratin complex 1, acidic, gene } \\
18 \mid \text { | }\end{array}$ & 15 & $\begin{array}{l}\text { Atividade molecular } \\
\text { estrutural }\end{array}$ \\
\hline Mm.25168 & Crip3 & $\begin{array}{l}\text { I | | |TLP-A | |Crip3| |Cysteine-rich } \\
\text { protein } 3||\end{array}$ & 17 & Proliferação de células $\mathrm{T}$ \\
\hline Mm.119 & Nr4a1 & 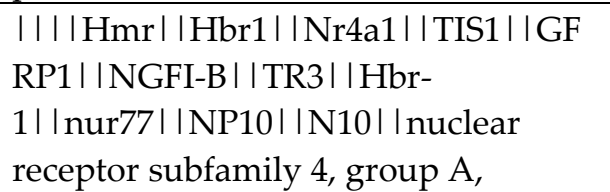 & 15 & $\begin{array}{c}\text { Indução de apoptose/Inibição } \\
\text { da ativação de } \\
\text { caspase/regulação da } \\
\text { transcrição }\end{array}$ \\
\hline
\end{tabular}




\begin{tabular}{|c|c|c|c|c|}
\hline & & member 1 II & & \\
\hline Mm.57175 & $\mathrm{Cd} 83$ & | |Cd83 | |CD83 antigen | | & 13 & $\begin{array}{c}\text { Expresso em subconjuntos de } \\
\text { linfócitos } \mathrm{T}\end{array}$ \\
\hline Mm.303231 & Cxcl12 & $\begin{array}{l}\text { I I | IScyb12 | ISdf1a | ISdf1b | I TLSF- } \\
\text { a I I Cxcl12 | I TLSF- } \\
\text { b | I TPAR1 | I PBSF/SDF-1 | I chemokine } \\
\text { (C-X-C motif) ligand 12 | | }\end{array}$ & 6 & $\begin{array}{c}\text { Proliferação de células } \\
\text { T/Atividade citocina e } \\
\text { quimiciona/quimiotaxia/regul } \\
\text { ação positiva de migração } \\
\text { celular } \\
\end{array}$ \\
\hline Mm.303231 & Cxcl12 & $\begin{array}{l}\text { I I I IScyb12 | ISdf1a | ISdf1b | I TLSF- } \\
\text { a I I Cxcl12 | I TLSF- } \\
\text { b | I TPAR1 | I PBSF/SDF-1 | I chemokine } \\
\text { (C-X-C motif) ligand 12 | | }\end{array}$ & 6 & $\begin{array}{c}\text { Proliferação de células } \\
\text { T/Atividade citocina e } \\
\text { quimiciona/quimiotaxia/regul } \\
\text { ação positiva de migração } \\
\text { celular } \\
\end{array}$ \\
\hline Mm.43778 & Rps14 & | |Rps14| | ribosomal protein S14|| & 18 & $\begin{array}{c}\text { Constituinte estrutural do } \\
\text { ribossomo }\end{array}$ \\
\hline Mm.103560 & Jundm2 & $\begin{array}{l}\text { ||||Jdp2||Jundm2||TIF||Jun } \\
\text { dimerization protein } 2||\end{array}$ & 12 & $\begin{array}{c}\text { Atividade repressora da } \\
\text { transcrição }\end{array}$ \\
\hline Mm.22564 & $\mathrm{H} 2-\mathrm{Eb} 1$ & $\begin{array}{l}\text { I | | |H2-Eb1 | | Ia4 | |H-2Eb | | Ia- } \\
4 \mid \text { | histocompatibility 2, class II } \\
\text { antigen E beta | | }\end{array}$ & 17 & $\begin{array}{l}\text { Receptor de MHC classe } \\
\text { II/apresentação de antígenos }\end{array}$ \\
\hline Mm.294315 & Capn10 & | |Capn10| |Capn8| |Calpain 10|| & 1 & Atividade peptidase/calpaina \\
\hline Mm.32043 & Prss16 & $\begin{array}{l}\text { I ITSSP | | Prss16 | | Protease, serine, } 16 \\
\text { (thymus) | | }\end{array}$ & 13 & Atividade catalítica \\
\hline Mm.7275 & Ccl25 & $\begin{array}{l}\text { | | | |CKb15 | IScya25 | |Ccl25 | | TECK | } \\
\text { | chemokine (C-C motif) ligand 25 | | }\end{array}$ & 8 & $\begin{array}{c}\text { Atividade citocina e } \\
\text { quimiciona/quimiotaxia/migra } \\
\text { ção de células } \\
\text { imunes/resposta } \\
\text { inflamatória/transdução de } \\
\text { sinal } \\
\end{array}$ \\
\hline Mm.235338 & $\mathrm{H} 2-\mathrm{Aa}$ & 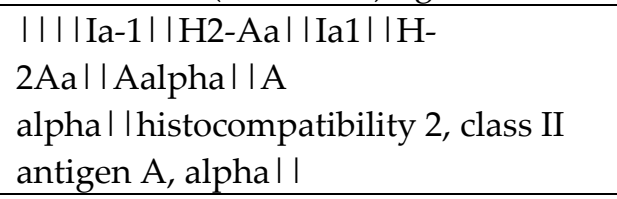 & 17 & $\begin{array}{c}\text { Receptor de MHC classe } \\
\text { II/apresentação de } \\
\text { antígenos/regulação positiva } \\
\text { de diferenciação de células T }\end{array}$ \\
\hline Mm.274180 & Pycr2 & $\begin{array}{l}\text { ||P5cr2||Pycr2 ||Pyrroline-5- } \\
\text { carboxylate reductase family, member } \\
2||\end{array}$ & 1 & $\begin{array}{c}\text { Biossíntese de } \\
\text { aminoácido/atividade } \\
\text { oxirredutase }\end{array}$ \\
\hline Mm.21454 & Cbr2 & $\begin{array}{l}\text { | | | | MLCR | | Cbr2 | | lung carbonyl } \\
\text { reductase | | Carbonyl reductase 2| | }\end{array}$ & 11 & $\begin{array}{c}\text { Oxidação de } \\
\text { NADH/Atividade } \\
\text { oxirredutase }\end{array}$ \\
\hline Mm.310772 & Robo1 & $\begin{array}{l}\text { | | DUTT1 | | Robo1 | | roundabout } \\
\text { homolog } 1 \text { (Drosophila) | | }\end{array}$ & 16 & $\begin{array}{c}\text { Diferenciação } \\
\text { celular/quimiotaxia/desenvolv } \\
\text { imento }\end{array}$ \\
\hline Mm.322843 & Isg20 & $\begin{array}{l}\text { | | | | DnaQ1 | I Isg20 | | 20kDa | I HEM45 } \\
\text { | I Interferon-stimulated protein | | }\end{array}$ & 7 & Atividade nuclease \\
\hline Mm.26633 & Plekhb1 & $\begin{array}{l}\text { I | | | Plekhb1 | | evt- } \\
\text { 1 | | Phret1 | | PHR1 | | pleckstrin } \\
\text { homology domain containing, family } \\
\text { B (evectins) member } 1 \text { | | }\end{array}$ & 7 & Proteína de ligação do Golgi \\
\hline Mm.24678 & Pard6g & $\begin{array}{l}\text { I | Pard6g I | par-6 partitioning } \\
\text { defective } 6 \text { homolog gamma }(C . \\
\text { elegans) | | }\end{array}$ & 18 & $\begin{array}{c}\text { Ciclo celular/cascata de } \\
\text { sinalização intracelular/citocinese }\end{array}$ \\
\hline
\end{tabular}




\begin{tabular}{|c|c|c|c|c|}
\hline Mm.322843 & Isg20 & $\begin{array}{l}\text { | | | | DnaQ1| | Isg20 | | 20kDa | | HEM45 } \\
\text { | | Interferon-stimulated protein | | }\end{array}$ & 7 & Atividade nuclease \\
\hline Mm.76649 & Vcam1 & $\begin{array}{l}\text { | | | | Vcam1 | | Vcam- } \\
\text { 1 | | CD106 | | Vascular cell adhesion } \\
\text { molecule 1 | | }\end{array}$ & 3 & $\begin{array}{l}\text { Adesão celular/adesão célula- } \\
\text { célula }\end{array}$ \\
\hline Mm.76649 & Vcam1 & $\begin{array}{l}\text { | | | | Vcam1 | | Vcam- } \\
\text { 1 | |CD106 | | Vascular cell adhesion } \\
\text { molecule 1 | | }\end{array}$ & 3 & $\begin{array}{l}\text { Adesão celular/adesão célula- } \\
\text { célula }\end{array}$ \\
\hline Mm.76649 & Vcam1 & $\begin{array}{l}\text { | | | | Vcam1 | | Vcam- } \\
\text { 1 | |CD106 | | Vascular cell adhesion } \\
\text { molecule 1 | | }\end{array}$ & 3 & $\begin{array}{l}\text { Adesão celular/adesão célula- } \\
\text { célula }\end{array}$ \\
\hline Mm.980 & Tnc & | || |Hxb ||Tnc||TN-C| | tenascin Cl| & 4 & \\
\hline Mm.275555 & Cnn3 & | |Cnn3 | | Calponin 3, acidic | | & 3 & Ligante de actina e calmodulina \\
\hline Mm.3596 & Cops2 & $\begin{array}{l}\text { | | | | Cops2 | I alien- } \\
\text { like | ISgn2 | | Trip15 | | Csn2 | I alien } \\
\text { homologue | | COP9 (constitutive } \\
\text { photomorphogenic) homolog, } \\
\text { subunit } 2 \text { (Arabidopsis thaliana) | | }\end{array}$ & 2 & $\begin{array}{l}\text { Proliferação celular/regulação } \\
\text { negativa da } \\
\text { transcrição/transdução de sinal }\end{array}$ \\
\hline
\end{tabular}

$M m=$ UniGene Acc. Number

Crom. = localização cromossômica

Os genes que definem a assinatura de timócitos, assim como sua localização cromossômica e suas respectivas funções estão apresentados na tabela V. 
Tabela V. Genes com expressão diferencial que definem a assinatura de timócitos.

\begin{tabular}{|c|c|c|c|c|}
\hline Mm & Símbolo & Nome do gene & Crom. & Função \\
\hline Mm.170905 & Phb & Prohibitin | |BAP32 | |Fyb & 15 & Metabolismo de DNA \\
\hline Mm.1149 & Irf2 & Irf-2 | | Interferon regulatory factor 2|| & 8 & $\begin{array}{c}\text { Regulação da } \\
\text { Transcrição/Resposta Imune }\end{array}$ \\
\hline Mm.1858 & $\mathrm{Cd} 8 \mathrm{a}$ & $\begin{array}{l}\text { Ly-35 | | Ly-2 | | Lyt-2 | | Ly-B | |CD8 } \\
\text { antigen, alpha chain }\end{array}$ & 6 & $\begin{array}{c}\text { Receptor de superfície } \\
\text { celular/transdução de } \\
\text { sinal/diferenciação de células T } \\
\text { citotóxica/regulação positiva da } \\
\text { sinalização mediada por cálcio } \\
\end{array}$ \\
\hline Mm.1137 & Itgb2 & 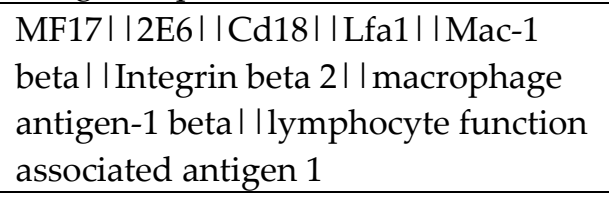 & 10 & $\begin{array}{l}\text { Adesão celular/adesão célula- } \\
\text { matriz/via de sinalização } \\
\text { mediada por integrina }\end{array}$ \\
\hline Mm.34339 & Socs7 & $\begin{array}{l}\text { Nap4 I ISuppressor of cytokine } \\
\text { signaling } 7\end{array}$ & 11 & $\begin{array}{l}\text { Cascata de sinalização } \\
\text { intracellular/regulação de } \\
\text { crescimento celular e } \\
\text { transdução de sinal }\end{array}$ \\
\hline Mm.290482 & Coro1a & $\begin{array}{l}\text { Clabp | | p57 | I coronin 1 I I coronin, } \\
\text { actin binding protein 1A }\end{array}$ & 7 & Ligante de actina \\
\hline Mm.2923 & $\mathrm{Il} 2 \mathrm{rg}$ & $\begin{array}{l}\text { CD132 I I gamma(c) I I common gamma } \\
\text { chain I I gamma C receptor I I common } \\
\text { cytokine receptor gamma } \\
\text { chain I I Interleukin } 2 \text { receptor, gamma } \\
\text { chain }\end{array}$ & $\mathrm{X}$ & $\begin{array}{c}\text { Receptor de superfície } \\
\text { celular/transdução de } \\
\text { sinal/receptor de } \\
\text { citocina/receptor de } \\
\text { interleucina }\end{array}$ \\
\hline Mm.123831 & Tcrb-V13 & T-cell receptor beta, variable 13 & $6 \mathrm{~B} 1$ & Resposta de defesa celular \\
\hline Mm.33903 & Sema4d & $\begin{array}{l}\text { coll4 | ISemcl2 | ISemacl2 | ICD100 I ISe } \\
\text { maj I I M-sema GI I semaphorin } \\
\text { HI I sema domain, immunoglobulin } \\
\text { domain (Ig), transmembrane domain } \\
\text { (TM) and short cytoplasmic domain, } \\
\text { (semaphorin) 4D }\end{array}$ & 13 & $\begin{array}{l}\text { Diferenciação } \\
\text { celular/desenvolvimento }\end{array}$ \\
\hline Mm.171518 & $\begin{array}{l}\text { 4930523C0 } \\
\text { 7Rik }\end{array}$ & $\begin{array}{l}\text { 4930523C07Rik | IRIKEN cDNA } \\
\text { 4930523C07 gene }\end{array}$ & 1 & \\
\hline Mm.425588 & Arid3b & $\begin{array}{l}\text { Arid3b | I Bdp I IDri2 I I AT rich } \\
\text { interactive domain 3B (Bright like) }\end{array}$ & 9 & Ligante de DNA \\
\hline Mm.34064 & Stat $5 b$ & $\begin{array}{l}\text { Stat } 5 \mathrm{~b} \mid \text { | signal transducer and } \\
\text { activator of transcription } 5 \mathrm{~B}\end{array}$ & 11 & $\begin{array}{c}\text { Casacata de sinalização } \\
\text { intracellular/regulação positiva } \\
\text { da transcrição para promotor } \\
\text { RNA polimerase II/regulação } \\
\text { de adesão celular/regulação de } \\
\text { diferenciação de células } \\
\text { epiteliais/transdução de sinal } \\
\end{array}$ \\
\hline Mm.335106 & $\mathrm{Cd} 3 \mathrm{~g}$ & $\begin{array}{l}\text { Ctg-3|T3g | ICtg3 | ICD3 antigen, } \\
\text { gamma polypeptide }\end{array}$ & 9 & $\begin{array}{l}\text { Complexo receptor de célula } \\
\text { T } \alpha \beta / \text { receptor de superfície } \\
\text { celular/transdução de sinal }\end{array}$ \\
\hline Mm.335106 & $\mathrm{Cd} 3 \mathrm{~g}$ & $\begin{array}{l}\text { Ctg-3 }|\mathrm{T} 3 \mathrm{~g}||\mathrm{Ctg} 3| \mid \mathrm{CD} 3 \text { antigen, } \\
\text { gamma polypeptide }\end{array}$ & 9 & $\begin{array}{l}\text { Complexo receptor de célula } \\
\text { T } \alpha \beta / \text { receptor de superfície } \\
\text { celular/transdução de sinal }\end{array}$ \\
\hline Mm.335106 & $\mathrm{Cd} 3 \mathrm{~g}$ & Ctg-3|IT3g|ICtg3|ICD3 antigen, & 9 & Complexo receptor de célula \\
\hline
\end{tabular}




\begin{tabular}{|c|c|c|c|c|}
\hline & & gamma polypeptide & & $\begin{array}{l}\text { T } \alpha \beta / \text { receptor de superfície } \\
\text { celular/transdução de sinal }\end{array}$ \\
\hline Mm.335106 & $\mathrm{Cd} 3 \mathrm{~g}$ & $\begin{array}{l}\text { Ctg-3 }|\mathrm{T} 3 \mathrm{~g}||\mathrm{Ctg} 3| \mathrm{ICD} 3 \text { antigen, } \\
\text { gamma polypeptide }\end{array}$ & 9 & $\begin{array}{l}\text { Complexo receptor de célula } \\
\text { T } \alpha \beta / \text { receptor de superfície } \\
\text { celular/transdução de sinal }\end{array}$ \\
\hline Mm.6246 & Blr1 & $\begin{array}{l}\text { CXC-R5 I I MDR15 I ICXCR- } \\
\text { 5 I IGpcr6 I ICXCR5 I I Burkitt } \\
\text { lymphoma receptor } 1\end{array}$ & 9 & $\begin{array}{l}\text { Ativação de célula B, receptor } \\
\text { de quimiocina CXC/receptor } \\
\text { acoplado a proteína G/ } \\
\text { transdução de sinal } \\
\end{array}$ \\
\hline Mm.2209 & $\mathrm{Cd} 4$ & L3T4| ILy-4| ICD4 antigen & 6 & $\begin{array}{l}\text { Adesão celular/transdução de } \\
\text { sianl via receptor/resposta } \\
\text { imune/regulação positiva de } \\
\text { sinalização mediada por } \\
\text { cálcio/diferenciação } \\
\text { celular/desenvolvimento }\end{array}$ \\
\hline Mm.367714 & Tnfrsf7 & $\begin{array}{l}\text { S152 | I Tp55| I Tnfrsf7 | ICd27 I Tumor } \\
\text { necrosis factor receptor superfamily, } \\
\text { member } 7\end{array}$ & 6 & $\begin{array}{c}\text { Apoptose/resposta } \\
\text { immune/transdução de sinal }\end{array}$ \\
\hline Mm.246654 & Arhgap4 & $\begin{array}{l}\text { c1 | | Arhgap } 4 \text { | | Rho GTPase activating } \\
\text { protein } 4\end{array}$ & $x$ & Ativador de GTPase \\
\hline Mm.367714 & Tnfrsf7 & $\begin{array}{l}\text { S152 I ITp55| ITnfrsf7 I ICd27 I Tumor } \\
\text { necrosis factor receptor superfamily, } \\
\text { member } 7\end{array}$ & 6 & $\begin{array}{c}\text { Apoptose/resposta } \\
\text { immune/transdução de sinal }\end{array}$ \\
\hline Mm.332590 & Selpl & $\begin{array}{l}\text { Selp1 | | Psgl1 | | Psgl- } \\
\text { 1 | |CD162 | ISelectin, platelet (p- } \\
\text { selectin) ligand }\end{array}$ & 5 & Adesão celular \\
\hline Mm.380679 & Dock2 & $\begin{array}{l}\text { Hch | I MBC I ICED- } \\
5 \text { | |Dock2 | IDedicator of cyto-kinesis } \\
2\end{array}$ & 11 & $\begin{array}{c}\text { Ativador de GTPase } \\
\text { RAC/regulação positiva da } \\
\text { transdução de sianl por } \\
\text { Rac/ativação e proliferação de } \\
\text { célula } \\
\text { T/quimiotaxia/estabelecimento } \\
\text { de polaridade na célula T }\end{array}$ \\
\hline Mm.170905 & Phb & Phb| | Prohibitin | |BAP32 & 15 & Metabolismo de DNA \\
\hline Mm.170905 & Phb & Phb||Prohibitin||BAP32 & 15 & Metabolismo de DNA \\
\hline Mm.18 & Zfp553 & | |Zfp553 | |Zinc finger protein 553 | | & 7 & \\
\hline Mm.2923 & $\mathrm{I} 2 \mathrm{rg}$ & $\begin{array}{l}\text { CD132 I I gamma(c) I I common gamma } \\
\text { chain I I gamma C receptor I I common } \\
\text { cytokine receptor gamma } \\
\text { chain I I Interleukin } 2 \text { receptor, gamma } \\
\text { chain }\end{array}$ & $\mathrm{x}$ & $\begin{array}{l}\text { Receptor de superfície } \\
\text { celular/transdução de } \\
\text { sinal/receptor de } \\
\text { citocina/receptor de } \\
\text { interleucina } \\
\end{array}$ \\
\hline Mm.2923 & $\mathrm{I} 2 \mathrm{rg}$ & $\begin{array}{l}\text { CD132 I I gamma(c) I I common gamma } \\
\text { chain I I gamma C receptor I I common } \\
\text { cytokine receptor gamma } \\
\text { chain I I Interleukin } 2 \text { receptor, gamma } \\
\text { chain }\end{array}$ & $x$ & $\begin{array}{c}\text { Receptor de superfície } \\
\text { celular/transdução de } \\
\text { sinal/receptor de } \\
\text { citocina/receptor de } \\
\text { interleucina } \\
\end{array}$ \\
\hline Mm.1972 & Rac2 & $\begin{array}{l}\text { Rac2 | I RAS-related C3 botulinum } \\
\text { substrate } 2\end{array}$ & 15 & $\begin{array}{c}\text { Transdução de sinal mediada } \\
\text { por pouco GTPase }\end{array}$ \\
\hline Mm.245363 & $\mathrm{Cd} 274$ & $\begin{array}{l}\text { Cd274 | IB7-H1 | | Pdcd1lg1 | | PD- } \\
\text { L1 | I CD274 antigen }\end{array}$ & 19 & Receptor \\
\hline Mm.10137 & Il16 & Il16 | Interleukin 16 & 7 & Quimiotaxia de células \\
\hline
\end{tabular}




\begin{tabular}{|c|c|c|c|c|}
\hline & & & & $\begin{array}{l}\text { imunes/indução de quimiotaxia } \\
\text { positiva/atividade citocina }\end{array}$ \\
\hline Mm.10137 & Il16 & Il16 | Interleukin 16 & 7 & $\begin{array}{c}\text { Quimiotaxia de células } \\
\text { imunes/indução de quimiotaxia } \\
\text { positiva/atividade citocina }\end{array}$ \\
\hline Mm.31630 & Tcf7 & $\begin{array}{l}\text { TCF-1 I I Tcf1 I I T cell factor-1 I IT-cell } \\
\text { factor } 1 \text { I I transcription factor } 7 \text {, T-cell } \\
\text { specific }\end{array}$ & 11 & $\begin{array}{c}\text { Receptor da via de sinalização } \\
\text { Wnt/regulação de } \\
\text { apoptose/regulação de } \\
\text { proliferação celular/fator de } \\
\text { transcrição }\end{array}$ \\
\hline Mm.210361 & Cd3e & $\begin{array}{l}\text { CD3epsilon I I T3e I ICD3 antigen, } \\
\text { epsilon polypeptide }\end{array}$ & 9 & $\begin{array}{l}\text { Complexo receptor de célula } \\
\text { T/transdução de sinal/sinapse } \\
\text { imunológica/regulação positiva } \\
\text { da sinalização mediada por } \\
\text { cálcio }\end{array}$ \\
\hline Mm.4545 & Tbxa2r & $\begin{array}{l}\text { III|Tbxa2r||Tp } \\
\text { receptor||thromboxane A2 receptor }\end{array}$ & 10 & $\begin{array}{l}\text { Receptor acoplado a proteína } \\
\text { G/transdução de sinal }\end{array}$ \\
\hline Mm.276131 & $\begin{array}{l}\text { 1200013B08 } \\
\text { Rik }\end{array}$ & $\begin{array}{l}\text { | | 1200013B08Rik | | RIKEN cDNA } \\
\text { 1200013B08 gene }\end{array}$ & $x$ & \\
\hline Mm.271937 & Ptprcap & $\begin{array}{l}\text { I | | | CD-45-AP | I LSM-1 I I protein } \\
\text { tyrosine phosphatase, receptor type, } \\
\text { C polypeptide-associated protein }\end{array}$ & 19 & $\begin{array}{c}\text { Proteína tirosina-fosfatase/via } \\
\text { de sinalização receptor } \\
\text { transmembrana proteína } \\
\text { tirosina-fosfatase }\end{array}$ \\
\hline Mm.34064 & Stat $5 b$ & $\begin{array}{l}\text { | |Stat5b| | signal transducer and } \\
\text { activator of transcription 5B }\end{array}$ & 11 & $\begin{array}{c}\text { Casacata de sinalização } \\
\text { intracellular/regulação positiva } \\
\text { da transcrição para promotor } \\
\text { RNA polimerase II/regulação } \\
\text { de adesão celular/regulação de } \\
\text { diferenciação de células } \\
\text { epiteliais/transdução de sinal }\end{array}$ \\
\hline Mm.30640 & Kcna3 & $\begin{array}{l}\text { Kca1-3||Mk-3||Kv1.3| | Potassium } \\
\text { voltage-gated channel, shaker-related } \\
\text { subfamily, member } 3\end{array}$ & 3 & $\begin{array}{l}\text { Canal de cátion/canal de íon } \\
\text { potássio }\end{array}$ \\
\hline Mm.52297 & Fnbp1 & $\begin{array}{l}\text { | | | |FBP17 | | Fnbp1 | | Formin binding } \\
\text { protein } 1 \text { | | }\end{array}$ & 2 & Proteína de ligação \\
\hline Mm.427613 & Abcg1 & $\begin{array}{l}\text { I | | Abcg1 | |Abc8| |ATP-binding } \\
\text { cassette, sub-family G (WHITE), } \\
\text { member } 1||\end{array}$ & 17 & $\begin{array}{l}\text { Atividade ATPase/atividade } \\
\text { permease }\end{array}$ \\
\hline Mm.86752 & Pglyrp2 & $\begin{array}{l}\text { | | | | Pglyrp2 | | Pglyrpl | | PGRP- } \\
\text { L | | tagL-alpha | | tagl- } \\
\text { beta | | Peptidoglycan recognition } \\
\text { protein 2 | | }\end{array}$ & 17 & Resposta imune \\
\hline Mm.1664 & Rab33b & $\begin{array}{l}\text { | | Rab33b | | RAB33B, member of RAS } \\
\text { oncogene family | | }\end{array}$ & 3 & $\begin{array}{c}\text { Transdução de sinal mediada } \\
\text { por pouca GTPase }\end{array}$ \\
\hline Mm.361 & Ptpn18 & 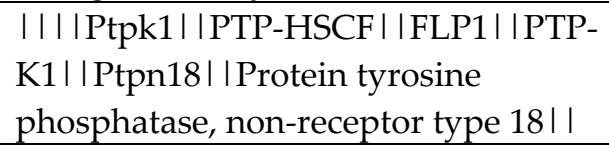 & 1 & Proteína tirosina-fosfatase \\
\hline Mm.10280 & Lat & $\begin{array}{l}\text { | | Lat | | linker for activation of } \mathrm{T} \\
\text { cells | | }\end{array}$ & 7 & $\begin{array}{l}\text { Resposta de defesa } \\
\text { cellular/synapse } \\
\text { imunológica/receptor } \\
\text { transmembrana via de }\end{array}$ \\
\hline
\end{tabular}




\begin{tabular}{|c|c|c|c|c|}
\hline & & & & $\begin{array}{c}\text { sinalização proteína tirosina- } \\
\text { quinase }\end{array}$ \\
\hline Mm.24163 & Pycard & $\begin{array}{l}\text { | | | | Pycard | |CARD5 | | TMS- } \\
\text { 1 | | Asc | | TNS1 | | PYD and CARD } \\
\text { domain containing | | }\end{array}$ & 7 & $\begin{array}{l}\text { Apoptose/ativador de protease } \\
\text { apoptótica/ciclo } \\
\text { celular/resposta } \\
\text { inflamatória/regulação negativa } \\
\text { do ciclo celular/regulação da } \\
\text { ativação de caspase }\end{array}$ \\
\hline
\end{tabular}

$M m=$ UniGene Acc. Number

Crom. = localização cromossômica

Os genes que definem a assinatura de timócitos imaturos, assim como sua localização cromossômica e suas respectivas funções estão apresentados na Tabela VI. 
Tabela VI. Genes com expressão diferencial que definem a assinatura de timócitos imaturos.

\begin{tabular}{|c|c|c|c|c|}
\hline Mm & Símbolo & Nome do gene & Crom. & Função \\
\hline Mm.432969 & Ppp1r9b & $\begin{array}{l}\text { Protein phosphatase 1, regulatory } \\
\text { subunit 9B }\end{array}$ & 11 & $\begin{array}{l}\text { Biogênese e organização do } \\
\text { citoesqueleto }\end{array}$ \\
\hline Mm.21772 & Smarcd2 & $\begin{array}{l}\text { SWI/SNF related, matrix associated, } \\
\text { actin dependent regulator of } \\
\text { chromatin, subfamily d, member } 2\end{array}$ & 11 & $\begin{array}{c}\text { Modificação da } \\
\text { cromatina/Regulação da } \\
\text { transcrição }\end{array}$ \\
\hline Mm.34064 & Stat $5 b$ & $\begin{array}{l}\text { Signal transducer and activator of } \\
\text { transcription } 5 \mathrm{~B}\end{array}$ & 11 & $\begin{array}{c}\text { Cascata de sinalização } \\
\text { intracellular/regulação positiva } \\
\text { da transcrição para promotor } \\
\text { RNA polimerase II/regulação } \\
\text { de adesão celular/regulação de } \\
\text { diferenciação de células } \\
\text { epiteliais/transdução de sinal }\end{array}$ \\
\hline Mm.10211 & Entpd5 & $\begin{array}{c}\text { Ectonucleoside triphosphate } \\
\text { diphosphohydrolase } 5\end{array}$ & 12 & $\begin{array}{c}\text { Atividade hidrolase/Ligante íon } \\
\text { magnésio }\end{array}$ \\
\hline Mm.432969 & Ppp1r9b & $\begin{array}{c}\text { Protein phosphatase 1, regulatory } \\
\text { subunit 9B }\end{array}$ & 11 & $\begin{array}{l}\text { Biogênese e organização do } \\
\text { citoesqueleto }\end{array}$ \\
\hline Mm.2987 & $\mathrm{Cd} 79 \mathrm{~b}$ & CD79B antigen/ B29/ Igbeta & 11 & $\begin{array}{l}\text { Complexo receptor de células } \\
\text { B/Transdução de sinal via } \\
\text { receptor }\end{array}$ \\
\hline Mm.194339 & Cbfa2t3h & $\begin{array}{c}\text { Core-binding factor, runt domain, } \\
\text { alpha subunit 2, translocated to, } 3 \\
\text { homolog (human) }\end{array}$ & 8 & Diferenciação de granulócitos \\
\hline Mm.276405 & Fkbp5 & FK506 binding protein 5 & 17 & Atividade isomerase \\
\hline Mm.44183 & Prr14 & Proline rich 14 & 7 & \\
\hline Mm.426017 & Dnahc8 & Dynein, axonemal, heavy chain 8 & 17 & $\begin{array}{l}\text { Movimentos baseados em } \\
\text { microtúbulos }\end{array}$ \\
\hline Mm.155547 & Sp2 & Sp2 transcription factor & 11 & Fator de transcrição \\
\hline Mm.4081 & Runx1/AML1 & Runt related transcription factor 1 & 16 & $\begin{array}{l}\text { Regulação da transcrição/Fator } \\
\text { de transcrição }\end{array}$ \\
\hline Mm.210361 & Cd3e & CD3 antigen, epsilon polypeptide & 9 & $\begin{array}{l}\text { Complexo receptor de célula } \\
\text { T/transdução de sinal/sinapse } \\
\text { imunológica/regulação positiva } \\
\text { da sinalização mediada por } \\
\text { cálcio }\end{array}$ \\
\hline Mm.210361 & $\mathrm{Cd} 3 e$ & CD3 antigen, epsilon polypeptide & 9 & $\begin{array}{l}\text { Complexo receptor de célula } \\
\text { T/transdução de sinal/sinapse } \\
\text { imunológica/regulação positiva } \\
\text { da sinalização mediada por } \\
\text { cálcio }\end{array}$ \\
\hline Mm.319006 & $\begin{array}{l}\text { A630038E17Ri } \\
k\end{array}$ & RIKEN cDNA A630038E17 gene & 14 & \\
\hline Mm.32475 & 9130430L19Rik & RIKEN cDNA 9130430L19 gene & 12 & \\
\hline Mm.297444 & Arpp21/ Tarpp & $\begin{array}{c}\text { Cyclic AMP-regulated } \\
\text { phosphoprotein, } 21\end{array}$ & 9 & \\
\hline Mm.878 & Ly6d & $\begin{array}{c}\text { Lymphocyte antigen } 6 \text { complex, locus } \\
\text { D }\end{array}$ & 15 & Resposta de defesa \\
\hline Mm.288809 & Xrcc6/ Ku70 & $\begin{array}{l}\text { X-ray repair complementing defective } \\
\text { repair in Chinese hamster cells } 6\end{array}$ & 15 & $\begin{array}{l}\text { Recombinação DNA/Reparo de } \\
\text { DNA/Atividade DNA helicase } \\
\text { dependente de ATP/Reparo de } \\
\end{array}$ \\
\hline
\end{tabular}




\begin{tabular}{|c|c|c|c|c|}
\hline & & & & quebras na dupla fita \\
\hline Mm.233951 & $\begin{array}{c}\text { Nck2/ } \\
\text { Grb4/Nckbeta }\end{array}$ & $\begin{array}{c}\text { Non-catalytic region of tyrosine } \\
\text { kinase adaptor protein } 2\end{array}$ & 1 & $\begin{array}{c}\text { Migração celular/Cascata de } \\
\text { sinalização } \\
\text { intracelular/Regulação negativa } \\
\text { de proliferação } \\
\text { celular/Atividade } \\
\text { quinase/Transdução de sinal }\end{array}$ \\
\hline Mm.214484 & Pag1 & $\begin{array}{l}\text { Phosphoprotein associated with } \\
\text { glycosphingolipid microdomains } 1\end{array}$ & 3 & Espaço extracelular \\
\hline Mm.7800 & Itpr2 & $\begin{array}{c}\text { Inositol 1,4,5-triphosphate receptor 2/ } \\
\text { Ip3r2; Itpr5 }\end{array}$ & 6 & $\begin{array}{c}\text { Transporte íon cálcio/Atividade } \\
\text { de receptor canal de cátion }\end{array}$ \\
\hline Mm.425261 & 5830443L24Rik & RIKEN cDNA 5830443L24 gene & 5 & $\begin{array}{c}\text { Resposta imune/Atividade } \\
\text { GTPase }\end{array}$ \\
\hline Mm.25620 & Dntt/ Tdt & $\begin{array}{c}\text { Deoxynucleotidyltransferase, } \\
\text { terminal }\end{array}$ & 19 & $\begin{array}{l}\text { Metabolismo, modificação e } \\
\text { replicação do DNA/Atividade } \\
\text { nucleotidilexotransferase }\end{array}$ \\
\hline Mm.25709 & Ing1 & Inhibitor of growth family, member 1 & 8 & $\begin{array}{c}\text { Regulação negativa do ciclo } \\
\text { celular/Regulação da } \\
\text { transcrição }\end{array}$ \\
\hline Mm.4857 & Camk2b & $\begin{array}{l}\text { Calcium/calmodulin-dependent } \\
\text { protein kinase II, beta }\end{array}$ & 11 & $\begin{array}{c}\text { Transporte de íon } \\
\text { cálcio/Transição de S-G1 do } \\
\text { ciclo celular mitótico/Atividade } \\
\text { quinase/Ligante calmodulina }\end{array}$ \\
\hline Mm.333499 & Fgfr1op2 & FGFR1 oncogene partner 2 & 6 & \\
\hline Mm.101369 & Pik3cg/ PI3K & $\begin{array}{l}\text { Phosphoinositide-3-kinase, catalytic, } \\
\text { gamma polypeptide }\end{array}$ & 12 & $\begin{array}{c}\text { Atividade quinase } \\
\text { fosfatidilinositol/Regulação } \\
\text { negativa da apoptose }\end{array}$ \\
\hline Mm.878 & Ly6d & $\begin{array}{c}\text { Lymphocyte antigen } 6 \text { complex, locus } \\
\text { D }\end{array}$ & 15 & Resposta de defesa \\
\hline
\end{tabular}

$M m=$ UniGene Acc. Number

Crom.$=$ localização cromossômica 
D)ISICIUISSÃAO) IE PIEIRSIPIECCTIIVAS 


\section{DISCUSSÃO}

\subsection{EXPRESSÃO GÊNICA PROMÍSCUA NO TIMO}

Os experimentos realizados em escala genômica objetivam avaliar os processos biológicos como um todo, mas com precisão molecular. Usando a tecnologia dos cDNA microarrays, a expressão dos mRNAs de milhares de genes pode ser mensurada simultaneamente. $\mathrm{O}$ uso da bioinformática na análise da expressão gênica revela uma profunda lógica molecular e biológica no entendimento da ativação e diferenciação celulares. Genes que codificam componentes de um mesmo complexo multi-proteico estão sob regulação coordenada. Esta regulação coordenada é também observada entre genes que apresentam seus produtos funcionais participando de um mesmo processo biológico (Staudt \& Brown 2000).

Estudos recentes que realizaram a análise do perfil da expressão gênica no sistema imune mostram que os processos de diferenciação e maturação, bem como a ativação de linfócitos, são acompanhados por mudanças paralelas de centenas de genes. Essa tecnologia também mostrou ser muito útil no estudo da "expressão promíscua de genes" (PGE) durante o desenvolvimento do timo fetal, além de possibilitar a análise de "retratos" transcricionais do timo e a caracterização de suas populações celulares, tais como, os timócitos em maturação, células estromais e macrófagos possibilitando, a chamada "microdissecção virtual" (Puthier et al. 2004).

A tolerância central da célula T devido à expressão de antígenos "tecidoespecíficos" no timo parece ser a base da indução da tolerância ao próprio (Klein \& Kyewski 2000). Sabendo que a expressão gênica promíscua (PGE) é propriedade fisiológica das células epiteliais medulares tímicas (mTECs), abriram-se perspectivas para determinarmos a modulação e a extensão da PGE em diferentes linhagens de camundongos, avaliando se os diferentes 
backgrounds genéticos exercem algum papel no controle deste tipo de expressão.

Os resultados do programa estatístico SAM nos despertaram para este fenômeno recentemente descrito e que está relacionado com a expressão de genes específicos de diversos órgãos nas células estromais medulares do timo. A PGE está implicada na indução da tolerância central de células T prevenindo a autoimunidade órgão-específica, um fator crítico envolvido na maturação dos timócitos antes que partam para a periferia.

A expressão gênica promíscua é identificada atualmente pela análise de dados de microarray dos diferentes genes órgãos-específicos representados no timo de camundongo, usando informação combinada do banco de dados público GNF Gene Expression Atlas (http://symatlas.gnf.org/SymAtlas) (Su et al. 2004). Este banco de dados mostra a expressão gênica de mais de 60 tecidos/órgãos do camundongo avaliada com microarrays da Affymetrix (www.affymetrix.com). A informação dos dados inclui o acesso ao GenBank (http://www.ncbi.nlm.nih.gov/Genbank/) , a localização cromossômica e a função molecular/biológica de cada gene analisado (Tabela II - Anexo II).

No presente trabalho, considerou-se somente os genes promíscuos cuja expressão foi significativamente induzida no timo (como indicado pelo algoritmo do programa SAM) e detectada em órgãos ou em tecidos diferentes, além do timo, e cujos níveis de expressão foram maiores do que a expressão média com relação a todos os órgãos restantes que aparecem no Atlas GNF. Além disso, 2 ESTs induzidas foram encontrados em C57Bl/6 e 38 em (Balb-c x C57Bl/6)F $F_{1}$ mas, como ainda não conhecemos suas respectivas representações em órgãos/tecidos, estas seqüências não foram consideradas.

Assim, o projeto de microarrays e a estringência estatística usada no programa SAM permitiram a observação da manifestação da PGE no início da recombinação $V(D) J$ de TRVB8.1 sendo que, houve uma sincronia observada na expressão gênica das linhagens C57Bl/6 e (Balb-c x C57Bl/6) $\mathrm{F}_{1}$, sugerindo uma função dos backgrounds genéticos diferentes na expressão de genes de órgãos 
parenquimatosos no timo e no controle da emergência e da extensão de PGE. No mesmo período de desenvolvimento, a linhagem Balb-c não exibiu PGE, considerando a estringência estatística utilizada neste estudo.

A evidência para a ocorrência de PGE no timo fetal pode ser associada com o sincronismo dos eventos moleculares da indução da tolerância da célula $\mathrm{T}$ durante a ontogenia. Os resultados mostram que PGE ocorre durante a maturação do timo; após a recombinação V(D)J do gene TRBV8.1 em Balb-c e coincidindo com a recombinação $\mathrm{V}(\mathrm{D}) \mathrm{J}$ do gene TRBV8.1 em C57Bl/6 e de (Balbc $\times$ C57Bl/6)F1.

Um dado prévio conseguido por nosso grupo mostrou que a PGE também ocorre após a expressão do gene Aire (Autoimmune regulator) durante a maturação do timo de camundongos (Cardoso et al. 2006b).

A indução da tolerância ao próprio deve ocorrer cedo, durante o desenvolvimento fetal do timo, impedindo reações auto-imunes patológicas. Este fenômeno é dependente da apresentação dos antígenos próprios de células T maduras com o reconhecimento do TCR pela molécula de MHC (Sprent \& Webb 1995; Hanahan 1998; Kishimoto \& Sprent 2000). A organização de genes TR funcionais, permitindo a expressão de TCR na superfície de células T, é dependente da emergência temporal da recombinação $V(D) J$ do gene TR, durante o desenvolvimento fetal do timo (Junta \& Passos 1998; Macedo et al. 1999; Espanhol et al. 2004).

A extensão da representação do próprio da maioria dos tecidos e de órgãos parenquimais é garantida pela PGE no timo, um fenômeno complexo que é exibido por mTECs, e envolve $5-10 \%$ de todos os genes conhecidos de camundongos e humanos. De acordo com isto, a complexidade de PGE aumenta em ordem ascendente, de cTECs para mTECs imaturas para mTECs CD80hi maduros. Estes diferentes pools de genes não são complementares, mas aditivos, isto é, não existe associação aparente entre a função molecular/biológica respectiva dos genes em órgãos parenquimatosos. E isto 
pode ser observado em nosso resultado (Tabela II e Figura 25). O significado da PGE no timo é associado com a tolerância central de células T (Sospedra et al. 1998; Bruno et al. 2002; Kyewski e Derbinski 2004; Magalhães et al. 2006).

A caracterização molecular da PGE durante o desenvolvimento fetal de diferentes linhagens isogênicas de camundongos é uma abordagem relevante na imunobiologia, e representa uma ferramenta potencial para esclarecer perguntas e na avaliação dos diferentes backgrounds genéticos que desempenham um papel no controle de PGE.

Além disso, este trabalho foi pioneiro na demonstração da ocorrência de PGE in vivo durante o desenvolvimento fetal do timo. Para avaliar se PGE neste sistema modelo é um fenômeno dependente do desenvolvimento, consideramos a expressão gênica diferencial durante a ontogenia comparando os dias de gestação (p.c.), como sendo o mais informativo no delineamento do pool de genes.

Dentro do que conhecemos, estes dados representam o primeiro estudo de associação entre o emergência da recombinação $V(D) J$ do gene TRV beta (TRVB8.1) e a ocorrência de PGE entre linhagens isogênicas de camundongos, com as implicações na demarcação fina dos processos chaves da indução da tolerância ao próprio.

Além disso, característica da distribuição aleatória de PGE no genoma sugere um modelo incomum de regulação da expressão gênica no timo que necessita de um estudo direcionado.

$\mathrm{O}$ gene Aire (Autoimmune regulator) parece estar diretamente implicado no controle da PGE, pois controla a expressão de um conjunto de genes de TSAs em mTECs, com uma tendência a genes que cuja expressão é preferencial de células diferenciadas (Anderson et al. 2002).

Mesmo assim, os genes que são controlados por Aire são altamente diversos com relação à estrutura e função, o que dificulta conclusões sobre seu modo de ação detalhado. Dados recentes indicaram que Aire contém domínios 
de ligação com DNA (Kumar et al. 2001), mas controla a transcrição de maneira independente da posição de promotores.

Entretanto, a significância destes achados para entendermos com precisão a ação de Aire in vivo ainda não está clara. Precisamos de evidências diretas de co-regulação dos genes de TSAs (expressão promíscua) devida a seqüências consenso em suas regiões de promotores/enhancers, nas quais atuaria a proteínas Aire ou mesmo outros complexos reguladores da transcrição (Kyewski \& Derbinski 2004).

Além disso, outros fatores epigenéticos tais como estado da conformação da cromatina e/ou níveis de metilação e/ou acetilação do DNA poderá estar associados com o controle da PGE no timo (Kyewski \& Derbinski 2004).

\subsection{ASSINATURAS DE EXPRESSÃO GÊNICA E MICRODISSECÇÃO VIRTUAL MOLECULAR DO TIMO}

A tecnologia dos cDNA microarrays tem sido adequadamente utilizada nos estudos de expressão gênica diferencial do timo de camundongos (Ramialison et al. 2002). Nosso grupo tem se empenhado nesta tarefa conseguindo evidenciar a participação de genes que regulam a recombinação de genes de receptores de células T (TRA e TRB) e também o reparo de DNA durante o desenvolvimento ontogenético deste órgão (Cardoso et al. 2006a). Além disso, conseguimos também mostrar a modulação de genes implicados na sinalização intracelular de células $\mathrm{T}$, incluindo a via do cálcio (Magalhães et al. 2005).

Como estes trabalhos foram realizados utilizando amostras de timo total e sabendo que este órgão é complexo e formado por diferentes tipos celulares, nos encontramos diante da necessidade de realizarmos uma verdadeira dissecção molecular virtual, em termos de expressão gênica, na tentativa de 
identificarmos os genes que se expressam de maneira diferente dentre estes tipos celulares.

Os diferentes locais bem estabelecidos no timo pelas células estromais formam o seu microambiente o qual é dividido em subcápsula tímica, córtex e medula facilitando passos distintos de maturação dos tímócitos. A manutenção deste microambiente tímico requer interações recíprocas entre os timócitos e células estromais, chamadas de "cross-talk" (Gray et al. 2006).

A formação do microambiente epitelial tímico maduro é pré-requisito essencial para a geração do conjunto de células T funcionalmente competentes. Células estromais tímicas medeiam várias fases do desenvolvimento dos timócitos na produção de células T maduras capazes de responder a antígenos estranhos e tolerar os próprios (Jenkinson et al. 2003).

A eventual suspeita de que a expressão gênica promíscua (PGE) poderia confundir assinaturas moleculares dos diferentes tipos celulares (quando se estuda timo total) foi afastada ou pelo menos minimizada, pelo entendimento de que a característica principal da PGE é a presença de genes de antígenos tecido-específicos (TSAs) que. A priori, não têm relacionamento funcional com o timo, já os genes que compõem as assinaturas moleculares do timo têm suas funções facilmente associadas com o papel das respectivas células.

A heterogeneidade das células que povoam o timo murino tem sido demonstrada usando anticorpos monoclonais específicos para vários determinantes. Esta abordagem possibilita a identificação de células epiteliais corticais (cTECs) e medulares (mTECs), endoteliais, fibroblastos, células dendríticas (DCs) e macrófagos dentro do microambiente tímico (Gray et al. 2006).

Além disso, o timo é povoado por timócitos em maturação que chegam da medula óssea e passam por processos de interação com o estroma tímico, importante na seleção positiva/negativa. 
Vários genes já foram identificados evidenciando seus respectivos papéis durante a maturação dos timócitos tais como, Rag-1 e 2 (Recombination activating gene 1,2 ), Il-7(Interleukin 7)/Il-7r (Interleukin 7 receptor), $\beta$ Selection, PU.1 e Gata-3 (GATA binding protein 3), ente outros (Anderson et al. 2002).

Uma das estratégias mais elegantes de se estudar a função destes genes é fazer uso dos camundongos nocautes $(\mathrm{KO})$, nos quais as seqüências genômicas de interesse foram inativadas por meio de recombinação homóloga induzida artificialmente por meio da introdução de um "vetor nocaute" carregando uma versão mutante do gene em questão (Bockamp et al. 2002).

No presente trabalho, fizemos uso de camundongos $\mathrm{KO}$ de alguns genes chaves no processo de maturação de timócitos tais como CD3e (CD3 antigen, epsilon polypeptide), Rag-1 (Recombination activating gene 1), Lat (Linker for activation of $T$ cells), TRA (T-cell receptor alpha), Relb (Avian reticuloendotheliosis viral (v-rel) oncogene related B), para evidenciar o papel dos mesmos na modulação da expressão gênica em larga escala (assinaturas de expressão gênica).

A identificação de tais assinaturas pode destacar a especialização funcional de cada população de células e deve ainda permitir a proposição de um papel para genes pouco caracterizados. Além disso, a maturação das células T e o desenvolvimento estromal são eventos interdependentes, e pela análise combinada dos modelos de camundongos $\mathrm{KO}$ que afetam um ou ambos os compartimentos tímicos foi possível sublinhar a modulação da expressão gênica do chamado "cross-talk".

De fato, a seleção dos dados de cDNA microarray tem permitido a microdissecção virtual do timo de camundongos em seus componentes celulares principais por meio da identificação dos transcritos celulares específicos (mRNAs) (Puthier et al. 2004). 
Assim, para revelar tais assinaturas transcricionais dos compartimentos celulares que constituem o timo do camundongo, usamos uma combinação de dados provenientes de timo inteiro de camundongos selvagens C57Bl/6 (WT) durante as fases do desenvolvimento fetal, assim como de camundongos $\mathrm{KO}$ $\left(\mathrm{CD} 3 \mathrm{e}^{\circ}, \operatorname{Rag}-1^{\circ}, \mathrm{Lat}^{\circ}, \mathrm{Tcr}^{\circ}, \operatorname{Relb}^{\circ}\right)$, além de amostras de células purificadas.

Comparando os perfis de transcrição durante a ontogenia do timo de camundongos WT com os de timo de camundongos $\mathrm{KO}$, nos ajudou na identificação do papel dos respectivos genes nocauteados no controle do transcriptoma dos compartimentos tímicos. Desta forma, observamos "panoramicamente" que os genes que compõem a assinatura de macrófago estão induzidos nas células dendríticas, linhagens celulares isoladas e timos de fetos. Já os genes que compõem a assinatura de estroma tímico, apresentaramse reprimidos em todas as linhagens celulares não estromais e induzidos em

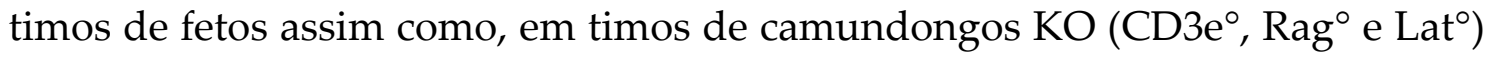
todos, sendo que todos os genes aparentemente não influem no estroma.

Os genes que compõem as assinaturas de timócito e timócitos em maturação apresentaram-se induzidos em timos fetal com 18 dias p.c, timócitos purificados, nocautes de TCR $\alpha^{\circ}$, camundongos WT e nocautes de Relb ${ }^{\circ}$.

Os camundongos $\mathrm{KO}$ de Rag $-^{\circ}{ }$ Lat $^{\circ}$, e de $\mathrm{CD} 3 \mathrm{e}^{\circ}$ foram escolhidos por mostrarem um bloqueio adiantado no desenvolvimento das células $\mathrm{T}$ e conseqüentemente um grande número de células T DN e de células estromais (Fischer \& Malissen 1998). Os timos dos camundongos KO de TCR $\alpha^{\circ}$ que apresentam falta de células $\mathrm{T}$ maduras e células estromais medulares diferenciadas foram usados para destacar as assinaturas transcricionais específicas destes compartimentos. Os camundongos $\mathrm{KO}$ para Relb ${ }^{\circ}$, um membro da família de NF- B, foram usados porque são caracterizados por uma medula tímica desorganizada e por uma falta de células medulares dendríticas (Naquet et al. 1999). 
Para definirmos as assinaturas moleculares de expressão gênica também fizemos comparações com as principais populações celulares tímicas isoladas, ou seja, células T CD25+ de camundongos Rag- $1^{\circ}$ (correspondendo aos estágios DN2 e DN3, CD25+DN), timócitos dos animais WT (DN, DP, CD4 $\left.+\mathrm{SP}, \mathrm{CD}^{+} \mathrm{SP}\right)$, e células $\mathrm{T}$ periféricas ativadas $\left(\mathrm{CD}^{+} \mathrm{P}\right.$ e $\left.\mathrm{CD} 4^{+} \mathrm{P}\right)$. Finalmente, RNA total de linhagens celulares (TECs) e células dendríticas (DC) também foram usados.

A abordagem que exploramos neste projeto, ou seja, a microdissecção molecular do timo por meio de assinaturas de expressão gênica se mostrou adequada na identificação de padrões genético-moleculares que caracterizam os principais tipos celulares que formam o timo. Além disso, a possibilidade de organizar tais assinaturas pelo agrupamento hierárquico, permitiu observar as eventuais inter-relações entre estes componentes.

\section{Genes que definem a assinatura molecular de macrófagos intratímicos}

Macrófagos têm como função principal agir na resolução de inflamações por meio da produção de citocinas e quimiocinas antiinflamatórias e também na eliminação de restos de tecidos e corpos apoptóticos por meio da fagocitose. Além disso, os macrófagos atuam como células apresentadoras de antígenos e acredita-se que este seja seu papel no interior do timo (Porcheray et al. 2005).

Os genes que definem a "assinatura de macrófagos" também foram altamente expressos em células dendríticas, assim como nas linhagens celulares (TECs), além de células $\mathrm{T}$ periféricas ativadas e em timo fetal (Figura 28, agrupamento 1).

A semelhança das assinaturas moleculares de expressão de macrófagos e de células dendríticas nos parece coerente tendo em vista a função destas células tanto no processamento como na apresentação de antígenos. 
Em relação às células $\mathrm{T}$ periféricas ativadas, estas expressaram alguns genes envolvidos com transdução de sinal e adesão celular, o que é perfeitamente explicado tendo em vista a sua atividade na periferia.

Já em relação ao desenvolvimento ontogenético do timo podemos destacar os processos de seleção positiva e negativa, nos quais os macrófagos possuem importante papel no processamento/apresentação de moléculas para o reconhecimento do próprio e na eliminação de corpos apoptóticos.

Os macrófagos possuem habilidade para se adaptar a mudanças de seu ambiente por meio de alterações no padrão funcional. Estas alterações são caracterizadas por regulação diferencial de cascatas de sinalização (adaptação reversível) que envolvem citocinas e quimiocinas (Stout et al. 2005).

O agrupamento 1 um inclui 39 genes, envolvendo aqueles relacionados com metabolismo celular basal e estrutural, e também genes relacionados com a função dos macrófagos em resposta a inflamação e com adesão celular, processos necessários para auxiliar a locomoção destas células dentro dos tecidos. Também foram observados genes relacionados com apoptose e transdução de sinais.

Podemos destacar um gene relacionado com atividade próinflamatória/citotóxica como Ccl3 (Chemokine (C-C motif) ligand 3), também com papel importante na transdução de sinais, e genes que podem influenciar a mudança de padrão funcional para atividade antiinflamatória/regeneração tecidual, tais como Spp1/Osteopontin* (Secreted phosphoprotein 1), também envolvido com adesão celular, os genes Ccl6/C10 (Chemokine (C-C motif) ligand 6), Cxcl4 (chemokine (C-X-C motif) ligand 4) que têm função sinalizadora devido a citocinas ou quimiocinas, além do gene Sfpi1 (SFFV

\footnotetext{
${ }^{*}$ Em alguns casos aparecem duas nomenclaturas para o mesmo gene devido a presença de aliases.
} 
proviral integration 1) que está envolvido na diferenciação dos macrófagos durante o estágio de desenvolvimento DN1 dos timócitos (Laiosa et al. 2006).

Também destacamos o gene do fator de transcrição ATF3 (Activating transcription factor 3), que suprime a expressão do gene $\mathrm{Ccl} 4$ em macrófagos controlando o risco de uma resposta inflamatória danosa (Khuu et al. 2006).

Dentre os genes envolvidos com a motilidade celular podemos destacar: CD9 (CD9 antigen), Capg (Capping protein (actin filament), gelsolin-like), e Adam8/CD156a (A disintegrin and metallopeptidase domain 8). E dentre os genes envolvidos em processos apoptóticos encontramos Cias1 (Cold autoinflammatory syndrome 1 homolog (human)) e Trib3 (Tribbles homolog 3 (Drosophila)), também envolvidos na regulação da transcrição de outros genes. E finalmente, dois genes de receptores transmenbranares, ligantes de $\operatorname{IgE}$ e de IgG, Fcer1g (Fc receptor, IgE, high affinity I, gamma polypeptide) e Fcgr3/CD16 (Fcg receptor III/|Fc receptor, IgG, low affinity III), respectivamente.

\section{Genes que definem a assinatura molecular de estroma tímico}

O timo fornece um microambiente original que gera de maneira eficiente linfócitos T $\alpha \beta$ capazes de responder a peptídeos estranhos no contexto de MHC próprio. Este microambiente é estabelecido por meio de interações de timócitos em desenvolvimento com componentes não linfóides denominados de estroma tímico. Este consiste de dois grupos de células, as estromais corticais (cTECs) e as medulares (mTECs), incluindo epitélio, endotélio. Fibroblastos reticulares, macrófagos, células dendríticas e células neuroendócrinas também povoam o estroma tímico. Estas células fornecem de maneira coletiva um ambiente essencial para vários estágios de desenvolvimento das células $\mathrm{T}$ envolvendo moléculas de superfície celular, citocinas e elementos da matriz extracelular que são essenciais para a maturação das células T (Gray et al. 2002). 
As células estromais tímicas fornecem sinais adicionais que são necessários para a diferenciação dos timócitos. Os sinais dos receptores de antígenos na superfície celular e os gerados pelo microambiente regulam o diverso programa transcricional abrangendo os maiores resultados da seleção positiva: a sobrevivência dos timócitos, finalização da recombinação dos genes de TCR, migração dentro da medula tímica, ligação nos TCR para respostas antigênicas e linhagens de células T auxiliares/citotóxicas (Mick et al. 2004)

Os genes que definem a assinatura de "estroma tímico" foram gradualmente expressos entre as amostras fetais, acompanhando a formação do microambiente tímico segundo o estágio de desenvolvimento fetal e respectivamente a maturação dos timócitos.

Notamos uma onda de indução gênica nos camundongos $\mathrm{KO} \mathrm{RAG}^{\circ}$ (camundongos que apresentam desenvolvimento dos timócitos bloqueados em DN), pois seu estroma tímico apesar ser predominantemente formado por cTECs, possui vários receptores de membrana que podem transduzir sinais distintos na via NFkB, todos requeridos por Relb, estimulando a proliferação e diferenciação de mTECs, assim não ocorrendo um profundo bloqueio na formação de mTEC como em Relb ${ }^{\circ}$. Analisando o agrupamento hierárquico de estroma tímico mostrado na Figura 28 podemos notar que o perfil de expressão dos camundongos $\operatorname{Rag}^{\circ}$, se assemelha aos camundongos $\mathrm{CD}^{\circ} \mathrm{e}^{\circ} \mathrm{e} \mathrm{Lat}^{\circ}$, os quais também não possuem bloqueio profundo da formação de mTEC e cTEC (Gray et al. 2006).

Camundongos nocautes Relb ${ }^{\circ}$ são deficientes de células mTECs e células dendríticas embora aparentemente, tenham um desenvolvimento de células $\mathrm{T}$ normais. A presença de DP em timo de camundongos TCR $\alpha^{\circ}$ mantém populações significantes de células $\mathrm{CTEC}^{\mathrm{lo}} \mathrm{e} \mathrm{mTEC}^{\mathrm{hi}}$, mas não de $\mathrm{mTEC}^{\mathrm{lo}}$. Assim, podemos dizer que o padrão de perfil de expressão do estroma tímico de camundongos $\mathrm{TCR} \alpha^{\circ}$ se assemelha ao de timo de camundongos WT (Gray et al. 2006). Portanto, é compreensível que haja semelhança entre as assinaturas 
moleculares de camundongos nocautes de $\mathrm{TCR} \alpha^{\circ}, \operatorname{Relb}^{\circ}$ e os camundongos WT.

O agrupamento 2 (Figura 28) inclui 63 genes incluindo os envolvidos com metabolismo basal e estrutural. Mas também há genes relacionados com funções essenciais para a formação do estroma tímico e para as diversas interações entre os timócitos e as células estromais.

A migração celular é crucial para a diferenciação dos timócitos. Quimiocinas e proteínas da matriz extracelular induzem a migração de timócitos. Um gene destacado no agrupamento de estroma tímico foi o Cxcl12/SDF1a (Chemokine (C-X-C motif) ligand 12) que codifica uma proteína de mesmo nome a qual induz a migração de timócitos por fibronectina plusalfa. Além disso, promove a proliferação de células $\mathrm{T}$ e apresenta atividade citocina/quimiocina. (Savino et al. 2002).

Outros dois genes destacados no agrupamento e que também codificam proteínas com função de proliferação de células T são Crip3 (Cysteine-rich protein 3) e Cops2 (Constitutive photomorphogenic homolog, subunit 2 (Arabidopsis thaliana)), sendo que este último também apresenta regulação negativa da transcrição e promove transdução de sinal. Além destes, podemos destacar o gene que codifica a proteína Efnb1/Ephrin-B1 (Ephrin B1) que regula positivamente a proliferação de células $\mathrm{T}$, além de promover a diferenciação celular.

Efnb1/Ephrin-B1 é uma proteína transmembrana ligante de quinases EphBs (receptores da família das proteínas tirosina quinase) expressos em células T. Esta proteína desempenha uma importante função na sinalização via TCR nos timócitos modulando a sobrevivência dos mesmos (Yu et al. 2006).

Ainda desempenhando função na diferenciação celular podemos destacar o gene Sfrp1 (Secreted frizzled-related sequence protein 1) que codifica um receptor da via de sinalização Wnt promovendo a diferenciação celular de células B (Dosen et al. 2006). 
Outros genes em destaque no agrupamento de estroma tímico são Gpr27 (G protein-coupled receptor 27) que codificam um receptor acoplado a proteína GTPase e participa nas transduções de sinal, e Ccl25 (Chemokine (C-C motif) ligand 25) que codifica uma proteína com atividade citocina/quimiocina e também participa das transduções de sinal, além das respostas inflamatórias e migração celular, pode ser uma das citocinas com maior destaque na colonização de timo fetal quando em conjunto com Ccl21, tal colonização se da por meio da quimioatração promovida pelas citocinas (Liu et al. 2005).

O agrupamento 2 também destaca genes que codificam proteínas com função de adesão celular, como o marcador de superfície celular VCAM1 (Vascular cell adhesion molecule 1) e também DDR1 (Discoidin domain receptor family, member 1), ambas além desta função são marcadores de superfície celular.

Os filamentos intermediários junto com microtúbulos e microfilamentos, compreendem as redes citoplasmáticas organizadas geralmente chamado de citoesqueleto. A maior função destes filamentos é manter a integridade celular na presença de alguma perturbação mecânica. Uma outra função é agir como suporte que liga e regula atividades de vários tipos de proteínas efetoras, por exemplo, receptores, quinases e adaptadoras. Assim, os membros da família dos filamentos intermediários são importantes componentes do estroma tímico, tendo destaque no agrupamento os genes para Krt18 (Keratin complex 1, acidic, gene 18), Krt2-6a (Keratin complex 2, basic, gene 6a) e Krt1-17 (Keratin complex 1, acidic, gene 17 ) (DePianto et al. 2004).

Mais dois genes muito importantes foram observados no agrupamento de estroma tímico, H2-Eb1 (Histocompatibility 2, class II antigen E beta) e H2Aa (Histocompatibility 2, class II antigen A, alpha), codificam uma das duas formas de proteínas de membrana heterodimérica e polimórficas que liga e exibe os fragmentos de peptídeo de antígenos de proteína na superfície das 
APCs para o reconhecimento pelos linfócitos $T$, assim participando da regulação positiva da diferenciação destes (Abbas \& Lichtman 2005).

Além disso, genes com função de fatores de transcrição foram encontrados neste agrupamento, Hey-1 (Hairy/enhancer-of-split related with YRPW motif 1), Dmrt 2 (Doublesex and mab-3 related transcription factor 2), Pax-1 (Paired box gene 1) e Foxn-1 (Forkhead box N1). Os dois últimos estão envolvidos no desenvolvimento e diferenciação do timo.

A proteína Pax-1 é expressa em células epiteliais tímicas e pode ser detectada na fase fetal e em adultos, sendo encontrada em maior quantidade em estágios iniciais de desenvolvimento do timo. A expressão de Pax-1 no epitélio tímico é necessário para o estabelecimento do microambiente tímico requerido para a normal maturação de células T (Wallin et al. 1996).

A proteína Foxn-1 é expressa todas as células epiteliais do timo antes da entrada dos progenitores linfóides e assim, é um marcador específico do tecido tímico. Foxn-1 é requerido para a imigração dos protimócitos dentro do primórdio tímico (Boehm et al. 2003).

\section{* Genes que definem a assinatura molecular de timócitos em maturação}

Timócitos imaturos encontra-se em um estágio duplo negativo (DN) CD3CD4-CD8, que podem ser subdivididos de acordo com as etapas de diferenciação: CD44+CD25-, CD44+CD25+, CD44-CD25+ e CD44-CD25', sendo que nestes dois últimos estágios iniciam-se os rearranjos dos genes de receptores de células T (TCR). Assim, as células que tem um progresso dos rearranjos dos genes TRB produtivo entram no ciclo celular, expandem e maturam-se para duplo-positivas (DP) CD4+CD8+. Com o rearranjo completo de TRA e produção completa do complexo TCR $\alpha \beta$, os timócitos DP são submetidos a seleção positivo-negativa (Blackburn \& Manley 2004). 
Os timócitos que sobrevivem a este processo seletivo expressam somente um co-receptor em sua superfície celular, resultando em células CD4 ${ }^{+}$e CD8 ${ }^{+}$ simples positivas (SP), representando o produto final do desenvolvimento de células T $\alpha \beta$ intratímicas. Em seguida, estes timócitos maduros saem do timo e migram para órgãos/tecidos periféricos (Haks et al. 1998).

O agrupamento 4 (Figura 28) incluiu 30 genes cuja a expressão é associada aos processos iniciais de maturação das células T (Tabela VI). Alguns genes que codificam marcadores de superfície celular importantes foram encontrados como CD3e (CD3 antigen, epsilon polypeptide), Ly6d (Lymphocyte antigen 6 complex, locus D) e CD79b (CD79B antigen/ B29/ Igbeta). Além disso, numerosos fatores nucleares, conhecidos como reguladores da expressão e dos rearranjos de genes TR foram altamente representados e agrupados na mesma rede da expressão. Sp2 (Sp2 transcription factor) é uma proteína "zinc finger" que esta apta para ligar o elemento GT box nos promotores de Tcrv (Kingsley \& Winoto 1992). Runx1/AML1 (Runt related transcription factor 1) tem sido associados como moduladores da acessibilidade ao DNA possibilitando a ação do complexo recombinase $\mathrm{V}(\mathrm{D}) \mathrm{J}$ (Hernandez-Munain \& Krangel 1995). Da mesma maneira, Xrcc6/Ku70 (X-ray repair complementing defective repair in Chinese hamster cells 6) e Dntt/Tdt (Deoxynucleotidyltransferase, terminal) são componentes da maquinaria da recombinação $\mathrm{V}(\mathrm{D}) \mathrm{J}$ e reparo do DNA e são cruciais para o rearranjo e a geração da diversidade na junção $\mathrm{V}(\mathrm{D}) \mathrm{J}$, respectivamente. A presença de Ppp1r9b/Tarpp (Protein phosphatase 1, regulatory subunit 9B) está de acordo, como recentemente sugerido, por sua importância no rearranjo de genes TR (Kisielow et al. 2001).

Além destes, podemos destacar genes envolvidos na regulação da proliferação celular como Nck2/ Grb4 (Non-catalytic region of tyrosine kinase adaptor protein 2) que codifica uma proteína adaptadora com identidade aos domínios Src $(\mathrm{SH})$ com atividade inibitória sobre elementos promotores 
regulados por c-jun/c-fos (Jahn et al. 2001) e medeia múltiplos eventos de sinalização celular iniciados por receptores de proteínas tirosina quinases (Braverman \& Quilliam 1999). Também encontramos Ing1 (Inhibitor of growth family, member 1), membro da família de supressores de tumor - ING, relacionado com várias atividades biológicas, incluindo controle ciclo celular, regulação da transcrição gênica, reparo do DNA e apoptose (Campos et al. 2004). Outro gene envolvido com a regulação da transcrição é Pik3cg/ PI3K (Phosphoinositide-3-kinase, catalytic, gamma polypeptide) com atividade quinase fosfatidilinositol participando de uma rede de sinalização na qual modula respostas de influxo de cálcio, regulando numerosos processos biológicos como crescimento celular, diferenciação, proliferação, migração, metabolismo e sobrevivência (Barbee \& Alberola-Ila 2006). Também podemos enfatizar o gene STAT5 (Signal transducer and activator of transcription 5B) cuja respectiva proteína pode desempenhar um papel na diferenciação de células T, talvez afetando os rearranjos V(D)J de Tcra e/ou Tcrb (Spits 2002).

Alguns genes ainda não caracterizados compartilham do mesmo perfil da transcrição, podendo funcionalmente ser relacionados aos eventos de rearranjo.

* Genes que definem a assinatura molecular de timócitos

O desenvolvimento dos linfócitos T intratímicos (timócitos) é definido por diferentes padrões de expressão de uma série de moléculas de superfície celular, incluindo CD4, CD8, CD25 e CD44, o que define estágios distintos de desenvolvimento destas células (Wang et al. 1999).

Os múltiplos passos no desenvolvimento das células T são determinados por alteração no padrão de expressão de genes linhagem-específicos e por rearranjos seqüenciais de genes TCR. É sabido que estes processos são controlados no nível do DNA por determinados fatores da transcrição, no 
citoplasma por moléculas de transdução de sinal incluindo inúmeras tirosinas quinases, e na superfície celular por receptores de citocinas (Shortman \& Wu 1996).

A ativação destas células depois de maduras depende de interações entre o TCR e os antígenos que culmina em uma cascata de eventos de sinalização, expressão de vários genes, secreção de citocinas e indução da atividade mitótica.

Observando a assinatura de expressão de timócitos (Figura 28, agrupamento 3) identificamos genes importantes para sua maturação, assim como outros que são requeridos para a ativação dos linfócitos, e os que promovem transdução de sinal, contribuindo com a diferenciação dos timócitos que se encontram no estroma tímico.

Analisando o agrupamento 3, podemos observar a clara superexpressão dos genes nas amostras de timócitos purificados. Os genes destacados nesta assinatura estão envolvidos direta ou indiretamente com as diversas fases do desenvolvimento dos timócitos. Assim fica coerente observação de altos níveis dos respectivos RNAm destes genes quando os timócitos encontram-se purificados (DN, DP, SP). Os genes também estão induzidos nas amostras de camundongos $\mathrm{KO} \mathrm{TCR}^{\circ}, \operatorname{Relb}^{\circ}$, e WT que apesar de estarem bloqueadas no estágio de DN de maturação dos timócitos promovem expressão de vários genes controladores destas fases de maturação.

Já nas amostras de timo em desenvolvimento, podemos observar uma onda crescente de expressão de acordo com a idade fetal, mostrando alteração no padrão de expressão gênica durante a ontogenia do timo. Também podemos destacar a expressão de genes nas amostras de camundongos $\mathrm{KO}\left(\mathrm{CD} 3 \mathrm{e}^{\circ}, \operatorname{Rag}^{\circ}\right.$ e Lat $\left.^{\circ}\right)$, que apesar do bloqueio no desenvolvimento em DN3, estas células podem sofrer maturação ineficiente.

O sistema imune possui pelo menos duas subclasses funcionais diferentes de linfócitos $\mathrm{T}$ que expressam TCR $\alpha \beta$. Linfócitos $\mathrm{T}$ auxiliares ou helper que 
expressam moléculas co-receptoras $\mathrm{CD} 4$, que reconhecem antígenos ligados a MHC de classe II e secretam citocinas que estimulam a proliferação e a diferenciação das células T e outras. E linfócitos T citolíticos ou citotóxicos que expressam moléculas co-receptoras CD8 e destroem células que produzem antígenos estranhos, como células infectadas por vírus e outros microorganismos intracelulares. Estas células reconhecem antígenos ligados a MHC de classe I, assim desempenham funções efetoras de secreção de linfocinas tóxicas ocasionando lise da célula alvo. A expressão dos genes CD4 (CD4 antigen) e CD8 (CD8 antigen, alpha chain) foram identificadas no conjunto que caracteriza a expressão dos timócitos.

No estágio fetal de 14-15 dias de gestação nenhuma população que expressa níveis significantes de CD4 poderia ser discernida, mas uma pequena população de timócitos CD3- CD4 $^{-} \mathrm{CD}^{-} \mathrm{CD}^{-} 5^{-}$expressando todos os marcadores foi detectada. Esta população gradualmente adquire CD4 até o 18⿳ㅜㅁ dia de gestação (Shortman \&Wu 1996).

As proteínas CD3 são importantes no desenvolvimento inicial dos timócitos e na transição da fase DN para DP. Na assinatura de timócitos destacamos os genes de CD3g (CD3 antigen, gamma polypeptide) e CD3e (CD3 antigen, epsilon polypeptide).

CD3g pode regular a função do pré-TCR com a capacidade de sinalização de módulos de ativação de imunoreceptores baseados em tirosina (ITAMs) presentes em seus domínios citoplasmáticos. CD3g tem um papel essencial no desenvolvimento de ambas as linhagens de células T $\alpha \beta$ e $\gamma \delta$ (Wang et al. 1998).

CD3e possui uma função específica no início do desenvolvimento das células T requerido para pré-TCR e complexo TCR e/ou transdução de sinal. Ausência de CD3e bloqueia o desenvolvimento dos pró-timócitos na fase imatura de $\mathrm{CD} 44-\mathrm{CD} 25^{+} \mathrm{DN} 3$ e, embora o rearranjo TCR $\beta$ ocorra, pode ocasionar pareamento errôneo na formação do complexo TCR/CD3. Mas, quando a ausência é somente da cadeia $\varepsilon$, os pró-timócitos podem se 
desenvolver para o estágio de DP ineficientemente, pois sua função é compensada por outras moléculas no complexo pré-TCR (Wang et al. 1999; DeJarnette et al. 1998).

A cauda citoplasmática de cada uma das proteínas do complexo CD3 contém uma cópia de um motivo de seqüência para sinalização que são chamadas de ITAMs. Os resíduos de tirosina no ITAMs tornam-se fosforilados em resposta ao reconhecimento do antígeno pelo TCR. Isto permite a ligação do domínio SH2 que contém proteínas para os ITAMs, o que permite o início de uma cascata de eventos de sinalização intracelular. $O$ acoplamento destas proteínas adaptadoras conduz, por exemplo, à ativação de pequenas proteínas GTPases tais como Ras e Rac, este último com o gene em destaque na assinatura de timócitos (Zhang et al. 1999).

Um número de moléculas adaptadoras tem sido descrito como ligantes diretos de proteínas adaptadoras e efetoras adicionais. Em células T encontra-se uma molécula adaptadora integral de membrana chamada Lat (Linker for activation of $\mathbf{T}$ cells), cuja expressão também caracterizou os timócitos. $\mathrm{Na}$ ativação do Tcr, Lat é fosforilado sobre múltiplas tirosinas, muito provável pelo ZAP-70 PTK. Lat se associa com Plcg-1, Cbl, Vav, PI-3 quinase, SLP-76, Grb2 e outras proteínas diretamente ou indiretamente, o que controla a ativação das GTPases das famílias Ras e Rac. Lat é indispensável para acoplamento do préTcr e via de sinalização intracelular, portanto, na ativação de células $\mathrm{T}$ via Tcr. Na ausência de Lat o desenvolvimento dos timócitos é bloqueado na fase de DN3 (Zhang et al. 1999).

Rho-GTPase específica de hematopoiese, Rac2 (RAS-related C3 botulinum substrate 2), é um gene regulador da transcrição, que codifica uma proteína da família Rho GTPases com atividade nas cascatas de quinase intracelular modulando a transcrição de múltiplos genes. Funções específicas dos membros da subfamília Rac da família Rho GTPase na regulação da sinalização intracelular de células hematopoiéticas. A importância da proteína 
Rho/Rac em diferentes aspectos da sinalização de células $\mathrm{T}$ tem sido focada na influência das proteínas GTPases sobre decisões na maturação dos linfócitos imaturos (Bustelo 2002).

As vias Rac e Ras são interconectadas nas células T. Proteínas Rho/Rac têm funções especializadas que depende dos estágios de maturação dos timócitos e estágios de resposta imune nas qual sua sinalização ocorre. Dependendo das GTPases envolvidas, estes eventos de sinalização influenciam a maturação e a seleção de timócitos, a proliferação dos linfócitos maduros, e/ou suas funções efetoras (Bustelo 2002)

$\mathrm{Na}$ assinatura de timócitos encontram-se vários genes ativadores de GTPases como por exemplo Arhgap4 (Rho GTPase activating protein 4), Dock2 (Dedicator of cyto-kinesis 2) que ativa Rac2 responsável por transdução de sinal mediada por GTPase, assim como Rab33b (RAB33B, member of RAS oncogene family).

Alguns genes que codificam receptores acoplados a proteínas GTPases são destacados no agrupamento de timócitos, tais como Blr1/CXCR5 (Burkitt lymphoma receptor 1). Este gene codifica o receptor de quimiocinas $C X C$, que possui importante papel em movimentos celulares direcionando as respostas imunes e mantendo a homeostase do sistema linfóide, por meio de transdução de sinal (Lipp \& Muller 2003).

A fosforilação e defosforilação de resíduos de treonina, serina e tirosina em proteínas tem emergido como evento chave na regulação da divisão, diferenciação e desenvolvimento celular, regulação do metabolismo e expressão gênica. Nos linfócitos, as proteínas fosfatases têm auxiliado na elucidação de vários eventos celulares dependentes de desfosforilação/fosforilação, como ativação destas células provocada por diversos efetores extracelulares.

Ptprcap/CD45 (Protein tyrosine phosphatase, receptor type, C polypeptide-associated protein), que é uma proteína tirosina fosfatase na qual seu gene se encontra no agrupamento de timócitos, apresenta um papel 
relevante na transdução de sinal culminando com a produção de Il-2 que é uma importante citocina na proliferação dos linfócitos.

Em condições fisiológicas, a ligação do complexo de histocompatibilidade (MHC) ao receptor TCR em resposta ao antígeno pode provocar ativação da proteína CD45, a qual ativa por desfosforilação de quinases desencadeia múltiplas fosforilações/desfosforilações e conseqüente ativação de cascatas de quinases ativadas por mitógenos (MAPKs) ou da via RAS, culminando ativação do complexo multicadeia Il-2rg (Interleukin 2 receptor, gamma chain), cujo gene se encontra em destaque no agrupamento de timócitos. Il-2r é um sistema de receptores para uma das mais importantes citocinas, interleucina 2 (Il-2) produzida ao final das vias de sinalização. Il-2 é conhecida como mediador de fenômenos de diferenciação e proliferação celular na resposta imune (Baksh \& Burakoff 2000).

A proteína CD45/Ptprcap atua na transdução de sinal em linfócitos e tem mostrado um importante papel no desenvolvimento, sinalização e apoptose de linfócitos T (Frearson \& Alexander 1996).

A estimulação de Il-2 induz a fosforilação de tirosina de inúmeras proteínas, como por exemplo, as proteínas JAK. A expressão de tirosina quinase JAK é necessária para as proteínas STAT tornarem-se fosforiladas depois da estimulação na citocina. Após a estimulação, pares das proteínas STAT ligam-se ao receptor do citocina em resíduos específicos de tirosina após a fosforilação. Em conseqüência, as proteínas STAT tornam-se fosforiladas, e após a dimerização, migram ao núcleo onde agem como fatores da transcrição. Assim, IL-2 induz a ativação da proteína Stat5b (Signal transducer and activator of transcription 5B), gene este encontrado em destaque no agrupamento de timócitos e que regula a transcrição de genes envolvidos com o crescimento celular (Zamorano et al. 1998).

As proteínas SOCS (supressores de sinais de citocinas) são reguladores negativos de citocinas. A sinalização JAK/STAT mediada por citocinas controla 
inúmeras respostas biológicas, incluindo funções imunes, crescimento celular, diferenciação e hematopoiese. A expressão de SOCS é induzida por citocinas, resultando na inibição da sinalização JAK/STAT (Cooney 2002).A família consiste nos membros CIS e SOCS1-SOCS7, cujo gene SOCS-7 (Suppressor of cytokine signaling 7) foi destacado no agrupamento de timócitos.

O gene CD274/B7-H1 (CD274 antigen), que codifica uma proteína de mesmo nome, identificada como ligante de PD-1, atua na coestimulação da proliferação de células $\mathrm{T}$ e produção de citocinas, e provavelmente também contribui nas interações entre células apresentadoras de antígenos e células T. Um bloqueio de B7-H1/CD274 resulta no acúmulo de IL-2, sugerindo um bloqueio na via de proliferação celular mediada por IL-2/IL-2R, assim interronpendo a progressão do ciclo celular (Yamazaki et al. 2005).

Outra interleucina importante é a Il-16 (Interleukin 16), que foi a primeira interleucina descrita sendo uma citocina quimioatraente para células T CD4, e tem sido mostrado também como sendo um iniciador da proliferação de células T, um modulador de respostas imunes e inflamação (Wilson et al., 2004).

Destacamos ainda neste agrupamento o gene Irf-2 (Interferon regulatory factor 2) que codifica uma proteína repressora da transcrição regulada por interferons do tipo 1 (IFN) (Simon et al. 1997), e tem principal papel na regulação da imunidade mediada por células. A família de IRF participa da regulação da expressão do gene FasL (Fas ligante) (Zhou et al. 1997).

A proteína Fas ligante provoca a morte celular via receptores de superfície celular das famílias FAS ou APT1, incluindo receptores da família fator de necroses tumoral (TNF). Embora a maioria dos timócitos expresse níveis elevados do antígeno Fas (CD95), o papel de Fas na sinalização da apoptose durante a maturação dos timócitos ainda não é bem clara. Apoptose mediada por Fas ocorre primeiramente nas subpopulações de timócitos CD4+CD8+, participando da seleção positiva/negativa (Zhou et al. 1997). 
Tnfrsf7/CD27 (Tumor necrosis factor receptor superfamily, member 7) que codifica um importante membro da família TNF foi destacado no agrupamento de timócitos, Tnfrsf7/CD27, e está envolvido em respostas imunes ativando linfócitos T e B, promovendo transdução de sinal, participando do desenvolvimento dos linfócitos $\mathrm{T}$ e mediando as respostas à apoptose. Outro gene envolvido em resposta apoptótica e que aparece no agrupamento foi Pycard (PYD and CARD domain containing), que regula a ativação de caspase em resposta a processos inflamatórios.

Proteínas Wnt são moléculas de sinalização secretadas que regula as interações célula-célula durante a embriogenêse em diferentes tecidos. Estas proteínas são requeridas no desenvolvimento de timócitos principalmente no estágio de pré-célula $\mathrm{T}$, embora trabalhos confirmem sua importância em estágios tardios de diferenciação dos timócitos. A via Wnt induz normalmente as interações de cofatores citoplasmáticos $\beta$-catenina com fatores de transcrição Tcf e Lef (fator de célula T), sendo que o gene Tcf-1 (Transcription factor 1) também foi destacado no agrupamento de timócitos da figura 20A (Staal 2003).

Nossos resultados mostraram a importância da utilização de modelos em desenvolvimento de camundongos nocautes $(\mathrm{KO})$.

A análise combinada de modelos de perturbação transcricional é suficiente para resumir os fenômenos principais relacionados à função do timo em uma maneira integrada. A identificação de assinaturas funcionalmente relevantes poderá nos dar uma idéia de indícios funcionais de transcritos ainda não caracterizados quando estes são co-expressos com genes bem conhecidos.

Além disso, a análise sistemática de modelos $\mathrm{KO}$ integrados com dados de camundongos normais potencia sobremaneira o sistema-modelo contribuindo com um melhor entendimento de eventos complexos que ocorrem no timo, incluindo o desenvolvimento das células $\mathrm{T}$ e também com sua microdissecção molecular. 


\section{PERSPECTIVAS}

1. Devido ao "cross-talk" que ocorre entre o estroma tímico e timócitos em maturação e, com relação aos estudos sobre expressão gênica promíscua, esta Tese abriu-nos a possibilidade de avaliarmos o efeito dos nocautes no controle deste tipo de expressão.

2. Devido à dificuldade de estabelecermos relações diretas entre os genes diferencialmente expressos observando as assinaturas moleculares, esta Tese também abriu-nos a perspectiva de reconstruirmos redes gênicas a partir dos dados de microarrays. 
COO) NCILIUIS(Õ)ES 


\section{CONCLUSÕES}

1) A comparação da expressão gênica promíscua no timo de diferentes linhagens isogênicas de camundongos nos evidenciou a participação do background genético no controle da PGE.

2) O acompanhamento do desenvolvimento ontogenético do timo possibilitou a demarcação do início da expressão gênica promíscua durante o desenvolvimento.

3) Foi possível definir assinaturas moleculares de expressão gênica de timo do camundongo assim como, dos principais componentes celulares que compõem este órgão.

4) Isto permitiu realizar a dissecção molecular virtual do timo.

5) O uso de dados de expressão gênica de timo de camundongos nocautes em comparação com dados de camundongos normais possibilitou a observação do controle exercido pelos respectivos genes nocauteados sobre a expressão gênica em grande escala. 


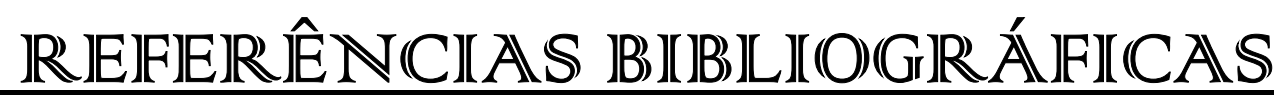




\section{REFERÊNCIAS BIBLIOGRÁFICAS}

Abbas AK, Lichtman AH (2005). Imunologia Celular e Molecular. 5a.Edição. WB Saunders Co. Philadelphia Penn. USA.

Anderson G, Jenkinson EJ. (2001). Lymphostromal interactions in thymic development and function. Immunol Reviews 1: $31-40$.

Anderson G, Jenkinson WE, Jones T, Parnell SM, Kinsella FAM, White AJ, Pongrac'z JE, Rossi SW, Jenkinson EJ. (2006). Establishment and functioning of intrathymic microenvironments. Immunol Reviews 209: 10-27.

Anderson MK, Hernandez-Hoyos G, Dionne CJ, Arias AM, Chen D, Rothenberg EV. (2002). Definition of regulatory network elements for $\mathrm{T}$ cell development by pertubation analysis with PU.1 and GATA-3. Developmental Biology 246: 103-121.

Baksh S, Burakoff SJ (2000). The role of calcineurin in lymphocyte activation. Semin Immunol. 12(4):405-415. Review.

Barbee SD, Alberola-Ila J. (2006). Phosphatidylinositol 3-kinase improves the efficiency of positive selection. Int Immunol. 18(6):921-30.

Bartblott T, Keller MP, Krenger W, Holländer GA. (2006). A short primer on early molecular and cellular events in thymus organogenesis and replacement. Swiss Med WKLY. 136: 365-369.

Benjamini Y, Hochberg Y (1995). Controlling the false discovery rate - a practical and powerful approach to multiple testing. J. R. Stat. Soc. B. 57:289-300.

Blackburn CC, Manley NR. (2004). Developing a new paradigm for thymus organogenesis. Immunoll Reviews 4: 278-289. 
Bodey B, Bodey B Jr, Siegel SE, Kaiser HE. (1997). Involution of the mammalian thymus, one of the leading regulators of aging. In Vivo. 11(5):421-40

Boehm T, Bleul CC, Schorpp M (2003). Genetic dissection of thymus development in mouse and zebrafish. Immunoll Reviews 195: 15-27.

Braverman LE, Quilliam LA. (1999). Identification of Grb4/Nckbeta, a src homology 2 and 3 domain-containing adapter protein having similar binding and biological properties to Nck. J Biol Chem. 274(9):5542-9

Bruno R, Sabater L, Sospedra M, Ferrer-Francesch X, Escudero D, Martínez-Cáceres E, Pujol-Borrel R (2002). Multiple sclerosis candidate autoantigens except myelin oligodendrocyte glycoprotein are transcribed in human thymus. Eur. J. Immunol. 32: 2737-2747.

Bockamp E, Maringer M, Spangenberg C, Fees S, Fraser S, Eshkind L, Oesch F, Zabel B. (2002). Of mice and models: improved animal models for biomedical research. Physiol Genomics 11: 115-132.

Bono H, Yagi K, Kasukawa T, Nikaido I, Tominaga N, Miki R, Mizuno Y, Tomaru Y, Goto H, Nitanda $\mathrm{H}$ et al. (2003). Systematic expression profiling of the mouse transcriptome using RIKEN cDNA microarrays. Genome Res.13:1318-1323.

Bustelo X R. (2002). Knocked out by Rho/Rac T-cell biology. Histol. Histopathol. 17: 871875.

Campos EI, Chin MY, Kuo WH, Li G. (2004). Biological functions of the ING family tumor suppressors. Cell Mol Life Sci. 61(19-20):2597-613.

Candeias, S., Muegge, K. and Durum, S. K. (1997) IL-7 receptor and VDJ recombination: trophic versus mechanistic actions. Immunity 6:501-508. 
Cardoso RS, Junta CM, Macedo C, Magalhães DA, Silveira ELV, Paula MO, Marques MMC, Mello SS, Zárate-Blasdés CR, Nguyen C, Houlgatte R, Donadi EA, SakamotoHojo ET, Passos GAS. (2006a) Hybridization signatures of gamma-irradiated murine fetal thymus organ culture (FTOC) reveal modulation of genes associated with T-cell receptor V(D)J recombination and DNA repair. Mol Immunol 43: 464-472.

Cardoso RS, Magalhães DA, Baião AMT, Junta CM, Macedo C, Marques MMC, Sakamoto-Hojo ET, Donadi EA, Passos GAS. (2006b). Onset of promiscuous gene expression in murine fetal thymus organ culture. Immunology 119(3):369-75.

Cooney RN (2002). Suppressors of cytokine signaling (SOCS): inhibitors of the JAK/STAT pathway. Shock. 17(2):83-90.

Cox JM (2001). Applications of nylon membrane arrays to gene expression analysis. Journal of Immunological Methods. 250: 3 - 13.

DeJarnette JB, Sommers CL, Huang K, Woodside KJ, Emmons R, Katz K, Shores EW, Love PE (1998). Specific requirement for CD3epsilon in T cell development. Proc. Natl. Acad. Sci. 95:14909-14914.

DePianto D, Coulombe PA (2004). Intermediate filaments and tissue repair. Exp Cell Res.301(1):68-76.

Derbinski J, Schulte A, Kyewski B, Klein L (2001). Promiscuous gene expression in medullary thymic epithelial cells mirrors the peripheral self. Nature Immunol. 2: 10321039.

Derbinski J, Gäbler J, Brors B. Tierling S, Jonnakuty S, Hergenhahn M, Peltonen L, Walter J, Kyewski B (2005). Promiscuous gene expression in thymic epithelial cells is regulated at multiple levels. J. Exp. Med. 202: 33-45. 
Derbinski J \& Kyewski B (2005).Linking signalling pathways, thymic stroma integrity and autoimmunity. Trends Immunol. 26(10): 503-506.

DeRyckere D, Mann DL , DeGregori J (2003). Characterization of transcriptional regulation during negative selection in vivo. J. Immunol. 171:802-811.

Dias Neto E, Correa RG, Verjovski-Almeida S, Briones MR, Nagai MA, da Silva W Jr, Zago MA, Bordin S, Costa FF, Goldman GH, Carvalho AF, Matsukuma A, Baia GS, Simpson DH, Brunstein A, de Oliveira PS, Bucher P, Jongeneel CV, O'Hare MJ, Soares F, Brentani RR, Reis LF, de Souza SJ, Simpson AJ. (2000). Shotgun sequencing of the human transcriptome with ORF expressed sequence tags. Proc Natl Acad Sci U S A. 28;97(7):3491-6

Dosen G, Tenstad E, Nygren MK, Stubberud H, Funderud S, Rian E (2006). Wnt expression and canonical Wnt signaling in human bone marrow B lymphopoiesis. BMC Immunol. 29: 7-13

Duggan DJ, Bittner M, Chen Y, Meltzer P, Trent JM (1999). Expression profiling using cDNA microarrays. Nat. Genet. 21: $10-14$.

Eisen M, Spellman P, Brown P, Botstein D (1998). Cluster analysis and display of genome-wide expression patterns. Proc. Natl. Acad. Sci. 95: 14863 - 14868.

Espanhol AR, Cardoso RS, Junta CM, Victorero G, Loriod B, Nguyen C, Passos GA. (2004). Large scale gene expression analysis of CBA/J mouse strain fetal thymus using cDNA-array hybridizations. Mol. Cell. Biochem. 206: 65-68.

Fischer A, Malissen B (1998). Natural and engineered disorders of lymphocyte development. Science 280:237-243.

Frearson JA, Alexander DR (1996). Protein tyrosine phosphatases in T-cell development, apoptosis and signalling. Immunol Today. 17(8):385-391. Review. 
Gray DH, Chidgey AP, Boyd RL (2002). Analysis of thymic stromal cell populations using flow cytometry. J. Immunol. Meth. 260:15-28.

Gray DHD, Ueno T, Chidgey AP, Malin M, Goldberg GL, Takahama Y, Boyd R. ((2005). Controlling the thymic microenvironment. Cur Opin Immunol 17: 137-143.

Gray DH, Seach N, Ueno T, Milton MK, Liston A, Lew AM, Goodnow CC, Boyd RL (2006). Developmental kinetics, turnover, and stimulatory capacity of thymic epithelial cells. Blood. 108: 3777-3785.

Ghendler Y, Hussey RE, Witte T, Mizoguchi E, Clayton LK, Bhan AK, Koyasu S, Chang HC, Reinherz EL (1997). Double-positive T cell receptor(high) thymocytes are resistant to peptide/major histocompatibility complex ligand-induced negative selection. Eur. J. Immunol. 27:2279-2289.

Ghendler Y, Mizoguchi E, Bhan AK, Clayton LK. (1998). Double-positive thymocytes resistant to antigen-MHC-induced negative selection lack active caspase. Int Immunol. 10(6):767-74.

Gotter J, Brors B, Hergenhahn M, Kyewski B (2004). Medullary epithelial cells of the human thymus express a highly diverse selection of tissue-specific genes colocalized in chromosomal clusters. J Exp Med 199:155-166.

Gotter J, Kyewski B (2004). Regulating self-tolerance by deregulating gene expression. Current Opinion Immunology 16: 741-745.

Haks MC, Krimpenfort P, Borst J, Kruisbeek AM (1998). The CD3gamma chain is essential for development of both the TCRalphabeta and TCRgammadelta lineages. Embo 17(7): 1871-1882. 
Hanahan D (1998). Peripheral-antigen-expressing cells in thymic medulla: factors in self-tolerance and autoimmunity. Curr. Op. Immunol. 10: 656-662.

Hedge P, Abernathy C, Gay S, Dharap R, Gaspard JE, Hugles E, Snerud E, Lee N, Quackenbush JA (2000). Bio Techniques 29: 548-562. Nem por autor nem por revista

Hernandez-Murain C, Krangel MS. (1995). C-Myb and core-binding factor/PEBP2 display functional synergy but bind independently to adjacent sites in the T-cell receptor $\delta$ enhancer. Mol. Cell. Biol. 15: 3090.

Heyer LJ, Kruglyak S, Yooseph S (1999). Exploring expression data: identification and analysis of coexpressed genes. Genome Research 9: 1106 - 1115.

Higgins JP, Wang L, Kambham N, Montgomery K, Mason V, Vogelmann SU, Lemley KV, Brown PO, Brooks JD, van de Rijn M (2003). Gene expression in the normal adult human kidney assessed by complementary DNA microarray. Mol. Biol. Cell 15:649-656.

Hoffmann R, Bruno L, Seidl T, Rolink A, Melchers F (2003). Rules for gene usage inferred from a comparison of large-scale gene expression profiles of $\mathrm{T}$ and $\mathrm{B}$ lymphocyte development. J. Immunol. 170:1339-1353.

Honore P, Granjeaud S, Tagett R, Deraco S, Beaudoing E, Rougemont J, Debono S, Hingamp P. (2006). MicroArray Facility: a laboratory information management system with extended support for Nylon based technologies. BMC Genomics. 20: 7:240.

Jahn T, Seipel P, Coutinho S, Miething C, Peschel C, Duyster J. (2001). Grb4/Nckbeta acts as a nuclear repressor of $\mathrm{v}$-Abl-induced transcription from $\mathrm{c}-\mathrm{jun} / \mathrm{c}$-fos promoter elements. J Biol Chem. 276(46):43419-27.

Jenkinson WE, Jenkinson EJ, Anderson G (2003). Differential requirement for mesenchyme in the proliferation and maturation of thymic epithelial progenitors. $J$. Exp. Med. 198(2): 325-332. 
Jolicoeur C, Hanahan D, Smith KM (1994). T-cell tolerance toward a transgenic betacell antigen and transcription of endogenous pancreatic genes in thymus. Proc. Natl. Acad. Sci. USA 91: 6707-6711.

Jordan BR (1998). Large-scale expression measurement by hybridization methods: from high-density membranes to "DNA chips". J. Biochem. (Tokyo) 124: 251 - 258.

Junta CM, Passos GA Jr. (1998). Emergence of TCR alpha/beta V(D)J recombination and transcription during ontogeny of inbred mouse strains. Mol. Cell. Bichem. 187: 67-72.

Khuu CH, Barrozo RM, Hai T, Weinstein SL (2006). Activating transcription factor 3 (ATF3) represses the expression of Ccl4 in murine macrophages. Mol Immunol. 44(7):1598-1605.

Kingsley C, Winoto A. (1992). Cloning of GT box-binding proteins: a novel Sp1 multigene family regulating T-cell receptor gene expression. Mol. Cell. Biol. 12: 4251.

Kishimoto H, Sprent J (1999). Several different cell surface molecules control negative selection of medullary thymocytes. J. Exp. Med. 190:65-73.

Klein L, Kyewski B (2000). Self-antigen presentation by thymic stromal cells: a subtle division of labor. Curr. Opin. Immunol. 12: 179-186.

Klein L, Kyewski B (2000). "Promiscuous" expression of tissue antigens in the thymus: a key to T-cell tolerance and autoimmunity? J. Mol. Med. 78:483-494

Kronenberg M, Sui G, Hood LE , Schastri N (1986). The molecular genetics of the T-cell antigen receptor and T-cell antigen recognition. Annu. Rev. Immunol. 4: 529-591.

Kurella M, Hslao li-li, Yoshida T, Randali JD, Chow G, Sarang SS, Jensen RV, Gullans SR. (2001). DNA Microarray Analysis of Complex Biologie Processes. J. Am Soc Nephrol 12:1072-1078. 
Kumar PG, Laloraya M, Wang CY, Ruan QG, Davoodi-Semiromi A, Kao KJ, She JX. (2001). The autoimmune regulator (Aire) is a DNA binding protein. J Biol Chem 276(44): $41357-41364$.

Kyewski B, Derbinski J (2004). Self-representation in the thymus: an extended view. Nat. Rev. Immunol 4:688-698

Laiosa CV, Stadtfeld M, Xie H, de Andres-Aguayo L, Graf T (2006). Reprogramming of committed $\mathrm{T}$ cell progenitors to macrophages and dendritic cells by C/EBP alpha and PU.1 transcription factors. Immunity. 25(5):731-744.

Lewis SM (1994). The mechanism of V(D)J joining: lessons from molecular, immunological, and comparative analyses. Adv. Immunol. 56: 27-150.

Lieber MR (1993). Site-specific recombination in the immune system. FASEB J. 29342944.

Lind EF, Prockop SE, Porritt HE, Petrie HT. Mapping precursor movement through the postnatal thymus reveals specific microenvironments supporting defined stages of early lymphoid development. J. Exp. Med. 194, 127-134 (2001)

Lipp M, Muller G (2003). Shaping up adaptive immunity: the impact of CCR7 and CXCR5 on lymphocyte trafficking. Verh Dtsch Ges Pathol. 87:90-101.

Lipshutz RJ, Fodor SP, Gingeras TR, Lockhart DJ (1999). High density synthetic oligonucleotide arrays. Nat. Genet. 21: 20-24.

Liu C, Ueno T, Kuse S, Saito F, Nitta T, Piali L, Nakano H, Kakiuchi T, Lipp M, Hollander GA, Takahama Y (2005). The role of CCL21 in recruitment of T-precursor cells to fetal thymi. Blood. 105(1):31-39. 
Macedo C, Junta CM, Passos GA (1999). Onset of T-cell receptor Vbeta8.1 and Dbeta2.1 $\mathrm{V}(\mathrm{D}) \mathrm{J}$ recombination during thymus development of inbred mouse strains. Immunol. Lett 69: 371-373.

Magalhães DA, Macedo C, Junta CM, Mello SS, Marques MM, Cardoso RS, SakamotoHojo ET, Donadi EA, Passos GA (2005). Hybridization signatures during thymus ontogeny reveals modulation of genes coding for T-cell signaling proteins. Molecular Immunology 42: 1043-1048.

Magalhães DA, Silveira EL, Junta CM, Mello SS, Sandrin-Garcia P, Fachin AL, Donadi EA, Sakamoto-Hojo ET, Passos GA (2006). Promiscuous gene expression in the thymus: the root of central tolerance. Clin. Dev. Immunol. 13(2-4): 81-99.

Mak TW, Penninger JM, Ohashi PS. (2001). Knockout mice: a paradigm shift in modern immunology. Nat Rev Immunol. 1(1):11-9. Review.

Menossi, M. et al (2000) Making colony PCR easier by adding gel-loading buffer to the amplification reaction. Biotechniques 28:424-426.

Mick VE, Starr TK, McCaughtry TM, McNeil LK, Hogquist KA (2004). The regulated expression of a diverse set of genes during thymocyte positive selection in vivo. $J$. Immunol. 173:5434-5444.

Naquet P, Naspetti M, Boyd R. (1999). Development, organization and function of the thymic medulla in normal, immunodeficient or autoimmune mice. Semin. Immunol. 11:47.

Passos GAS, Nguyen C, Jordan B (2000). Projeto Transcriptoma - Análise da expressão gênica em larga escala usando DNA-arrays. Biotecnologia Ciência E Desenvolvimento. Ano II, 12: $34-37$. 
Paul WE (1993). Fundamental Immunology 3th Ed. Raven Press Ltd. New York.

Pereira E, Tamia-Ferreira MC, Cardoso RS, Mello SS, Sakamoto-Hojo ET, Passos GA, Donadi EA. (2004). Immunosuppressive therapy modulates $\mathrm{T}$ lymphocyte gene expression in patients with systemic lupus erythematosus. Immunology 113(1): 99-105.

Porcheray F, Viaud S, Rimaniol AC, Leone C, Samah B, Dereuddre-Bosquet N, Dormont D, Gras G (2005). Macrophage activation switching: an asset for the resolution of inflammation. Clin Exp Immunol 142(3):481-489.

Puthier D, Joly F, Irla M, Saade M, Victorero G, Loriod B, Nguyen C (2004). A general survey of thymocyte differentiation by transcriptional analysis of knockout mouse models. J. Immunology, 173:6109-6118.

Ramialison M, Mohr E, Nal B, Saboul T, Carrier A, Tagett R, Granjeaud S, Nguyen C, Gautheret D, Jordan BR, Ferrier P. (2002). Expression profiling in mouse fetal thymus reveals clusters of coordinately expressed genes that mark individual stages of T-cell ontogeny. Immunogenetics. 54:469-478.

Rugh R (1968). The Mouse. Its Reproduction and Development. Burgess Publishing Company.

Sambrook J, Fritch EF, Maniats T (1989). Molecular cloning. A laboratory manual. Cold Spring Harbor Press. New York.

Sakamoto-Hojo ET, Mello SS, Cardoso RS, Passos GAS (2003). Utilização de genômica funcional e proteômica em mutagênese (Cap. 12). Mutagênese Ambiental. Ed. ULBRA. Pp.356. 
Savino W, Mendes-da-Cruz DA, Silva JS, Dardenne M, Cotta-de-Almeida V (2002). Intrathymic T-cell migration: a combinatorial interplay of extracellular matrix and chemokines? Trends Immunol. 23(6):305-313.

Savino W, Ayres Martins S, Neves-dos-Santos S, Smaniotto S, Ocampo JS, Mendes-daCruz DA, Terra-Granado E, Kusmenok O, Villa-Verde DM. (2003). Thymocyte migration: an affair of multiple cellular interactions? Braz J Med Biol Res. 36(8):10151025.

Savino W, Mendes-Da-Cruz DA, Smaniotto S, Silva-Monteiro E, Villa-Verde DM. (2004). Molecular mechanisms governing thymocyte migration: combined role of chemokines and extracellular matrix. J. Leukoc Biol. 75(6):951-61.

Savino W. (2006). The Thymus Is a Common Target Organ in Infectious Diseases. PLoS Pathog. 2006 Jun;2(6):e62. Review.

Sevignani C, Calin GA, Siracusa LD, Croce CM. (2006). Mammalian microRNAs: a small world for fine-tuning gene expression. Mamm Genome. 17(3):189-202.

Schmitz I, Clayton LK, Reinherz EL (2003). Gene expression analysis of thymocyte selection in vivo. Int. Immunol. 15:1237-1248.

Simon AK, Desrois M, Schmitt-Verhulst AM. (1997). Interferon-regulatory factors during development of CD4 and CD8 thymocytes. Immunology. 91(3):340-5

Shortman K, Wu L (1996). Early T lymphocyte progenitors. Annu. Rev. Immunol. 14: 2947.

Smyth GK. (2004). Linear models and empirical Bayes methods for assessing differential expression in microarrays experiments. (2004). Statistical Applications in Genetics and Molecular Biology 3, No. 1, Article 3. 
Sospedra M, Ferrer-Francesch X, Dominguez O, Juan M, Foz-Sala M, Pujol-Borrell R (1998). Transcription of a broad range of self-antigens in human thymus suggests a role for central mechanisms in tolerance toward peripheral antigens. J. Immunol. 161: 591829.

Spellman P, Sherlock G, Zhang M, Iyer V, Anders K, Eisen M, Brown P, Botstein D, Futcher B (1998). Comprehensive identification of cell cycle-regulated genes of the yeast Saccharomyces cerevisiae by microarray hybridization. Mol. Biol. Cell 9: 3273 3297.

Spits H (2002). Development of alphabeta T cells in the human thymus. Nat. Rev. Immunology 2:760-772.

Sprent J, Webb SR (1995). Intrathymic and extrathymic clonal deletion of T cells. Curr. Opin. Immunol. 7: 196-205.

Staal FJ, Clevers HC (2003). Wnt signaling in the thymus. Curr Opin Immunol. 15(2):204208.

Staudt LM, Brown PO. (2000). Genomic view of the immune system. Annuv Rev Immunol 18: 829-859.

Stout RD, Jiang C, Matta B, Tietzel I, Watkins SK, Suttles J (2005). Macrophages sequentially change their functional phenotype in response to changes in microenvironmental influences. J. Immunol. 175(1):342-349.

Su AI, Cooke MP, Ching KA, Hakak Y, Walker JR, Wiltshire T, Orth AP, Vega RG, Sapinoso LM, Moqrich A, Patapoutian A, Hampton GM, Schultz PG,Hogenesch JB (2002). Large-scale analysis of the human and mouse transcriptomes. Proc. Natl. Acad. Sci. USA 99(7):4465-4470. 
Su AI, Wiltshire T, Batalov S, Lapp H, Ching KA, Block D, Zhang J, Soden R, Hayakawa M, Kreiman G, Cooke MP, Walker JR, Hogenesch JB (2004). A gene atlas of the mouse and human protein-encoding transcriptomes. Proc. Natl. Acad. Sci. USA 101(16): 6062-6067.

Tusher VG, Tibshirani R, Chu G (2001). Significance analysis of microarrays applied to the ionizing radiation response. Proc. Natl. Acad. Sci. USA 98(9): 5116 - 5121.

van Ewijk W, Holländer G, Terhorst C, Wang B. (2000). Stepwise development of thymic microenvironments in vivo is regulated by thymocyte subsets. Development 127 : 1583-1591.

van Gent DC, Ramsden DA, Gellert M. (1996) The RAG1 and RAG2 proteins establish the 12/23 rule in $\mathrm{V}(\mathrm{D}) \mathrm{J}$ recombination. Cell 85(1):107-13

van Hal NLW, Vorst O, van Houwelingen AMML, KoK EJ, Peijnenburg A, Aharoni A, van Tunen AJ, Keijer J (2000). The application of DNA microarrays in gene expression analysis. Journal of Biotechnology 78: $271-280$.

Villa-Verde DM, Mello-Coelho V, Lagrota-Candido JM, Chammas R, Savino W. (1995). The thymic nurse cell complex: an in vitro model for extracellular matrix-mediated intrathymic T cell migration. Braz J Med Biol Res 28(8):907-12

Zamorano J, Keegan AD. (1998). Regulation of apoptosis by tyrosine-containing domains of IL-4R alpha: Y497 and Y713, but not the STAT6-docking tyrosines, signal protection from apoptosis. J Immunol. 161(2):859-67

Zhang W, Sommers CL, Burshtyn DN, Stebbins CC, DeJarnette DN, Trible RP, Grinberg A, Tsay HC, Jacobs HM, Kessler CM, Long EO, Love PE, Samelson LE (1999). Essential role of LAT in T cell development. Immunity 10:323-332. 
Zhou T, Fleck M, Mueller-Ladner U, Yang P, Wang Z, Gay S, Matsumoto S, Mountz JD (1997). Kinetics of Fas-induced apoptosis in thymic organ culture. J Clin Immunol. 17(1):74-84.

Wallin J, Eibel H, Neubüser A, Wilting J, Koseki H, Balling R (1996). Pax1 is expressed during development of the thymus epithelium and is required for normal T-cell maturation. Development 122: 23-30.

Wang B, Wang N, Salio M, Sharpe A, Allen D, She J, Terhorst C (1998). Essential and partially overlapping role of CD3gamma and CD3delta for development of alphabeta and gammadelta T lymphocytes. J. Exp. Med. 188:1375-1380.

Wang B, Wang N, Whitehurst CE, She J, Chen J, Terhorst C (1999). T lymphocyte development in the absence of CD3 epsilon or CD3 gamma delta epsilon zeta. J. Immunol. 162:88-94.

Whitney LW, Becker KG (2001). Radioactive 33-P probes in hybridization to glass cDNA microarrays using neural tissues. J. Neurosci Methods. 106: 9 - 13.

Wilson KC, Center DM, Cruikshank WW (2004). The effect of interleukin-16 and its precursor on T lymphocyte activation and growth. Growth Factors. 22(2):97-104

Yamazaki T, Akiba H, Koyanagi A, Azuma M, Yagita H, Okumura (2005). Blockade of B7-H1 on macrophages suppresses CD4+ $\mathrm{T}$ cell proliferation by augmenting IFNgamma-induced nitric oxide production. J. Immunol. 1586-1592.

Yang SJ, Ahn S, Park CS, Holmes KL, Westrup J, Chang CH, Kim MG. (2005). The quantitative assessment of MHC II on thymic epithelium: implications in cortical thymocyte development. International Immunology 18(5): 729-739. 
Yu G, Mao J, Wu Y, Luo H, Wu J (2006). Ephrin-B1 is critical in T-cell development. J. Biol. Chem. 281: 10222-10229.

Xiang CC, Chen Y. (2000). cDNA microarrays technology and applications. Biotechnology Advances. 18: 35-46.

Yang YH, Speed T. (2002). Desing issues for cDNA microarrays experiments. Nature Reviews Genetics. 3: 579-588. 
AN NEX(O)S 
$A \mathbb{N E X ( O ) ~ I I ~}$

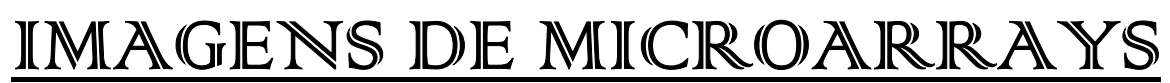




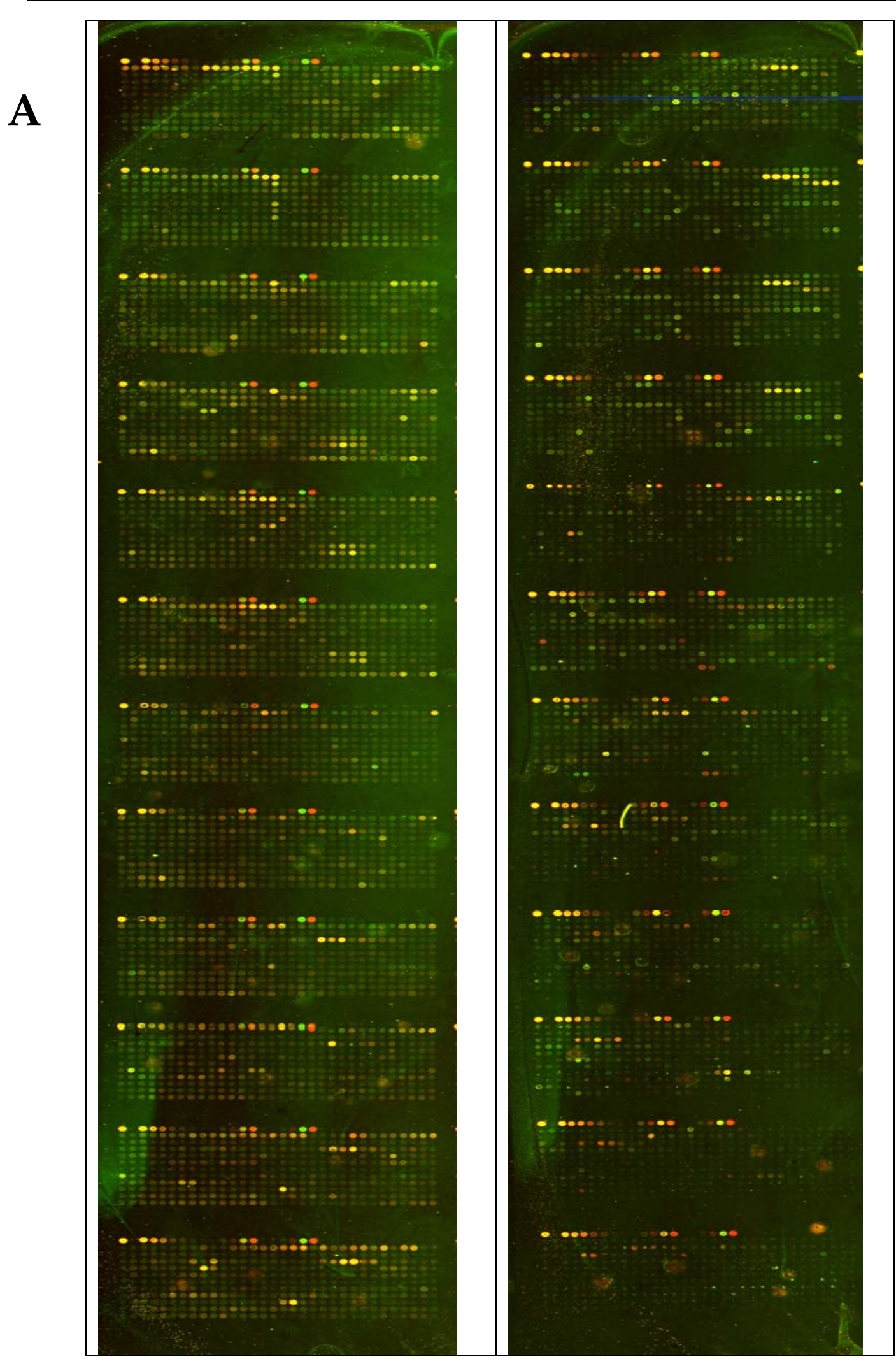

B

Figura 27. Imagens típicas de cDNA microarrays obtidas durante este estudo. (4.500 seqüências alvos) preparados em lâminas de vidro (Corning UltraGaps 40015). Hibridações com sondas fluorescentes (verde Cy3 = pool de referência e vermelho Cy5 = amostras). A) Amostra timo e B) Amostra de pool de órgãos. A aquisição das imagens foi realizada em "scanner" a laser GenIII Laser Scanner (Amershm Biosciences). 

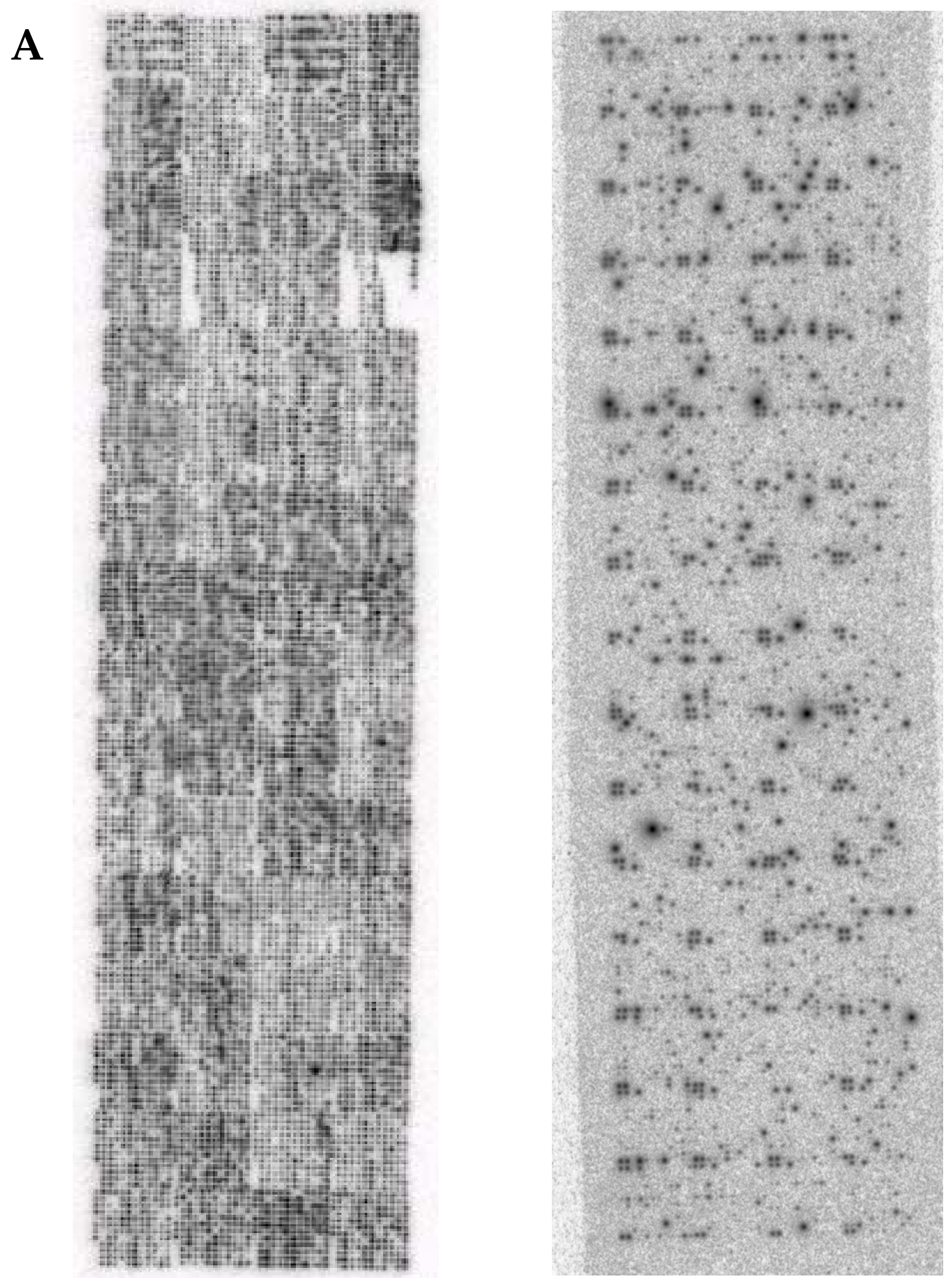

B

Figura 28. Imagens típicas de cDNA microarrays obtidas durante este estudo, (8750 seqüências alvo) preparados em membranas de náilon (Hybond $N+$ GE Healthcare). Hibridações com sondas radioativas marcadas com ${ }^{33} \mathrm{P}$. A) Hibridação com sonda oligovetor. B) Hibridação com amostras de timo fetal. A aquisição das imagens foi realizada em aparelho leitor de fósforo incorporado (BAS 5000 Fuji, Tokyo, Japão). 
A NEX(O) IIII

TCABIEILA IDIE GIENIES IDO) SAMI 
Tabela II. Genes diferencialmente e significantemente induzidos em timo de C57Bl/6 e ( Balb-c x $\left.{ }^{\lambda} \mathrm{C} 57 \mathrm{Bl} / 6\right) \mathrm{F}_{1}$ detectados pelo programa SAM. Fold change $\geq 1$ and FDR = false discovery rate.

\section{C57BI/6 strain (fold change $=1.5$ and FDR $\sim 0.05$ )}

\begin{tabular}{|c|c|c|c|c|}
\hline Gene name & $\begin{array}{l}\text { GenBank } \\
\text { accession }\end{array}$ & Chromos & $\begin{array}{l}\text { Predominant } \\
\text { expression }\end{array}$ & $\begin{array}{l}\text { Molecular/biological } \\
\text { function }\end{array}$ \\
\hline $\begin{array}{c}\text { Hexosaminidase } B \\
\text { (Hexb) }\end{array}$ & NM_010422 & 13 & $\begin{array}{l}\text { Adipose tissue, bone, } \\
\text { amygdale, frontal cortex, } \\
\text { trigeminal, cerebral cortex, } \\
\text { dorsal root ganglia, dorsal } \\
\text { striat um, hippocampus, } \\
\text { hypothalamus, olfactory } \\
\text { bulb, spinal cord'lower, } \\
\text { spinal cord upper, } \\
\text { substantia nigra, blatocystis, } \\
\text { placenta, small intestine, } \\
\text { B220+B-cells, lymphnode, } \\
\text { vomeronasal organ, salivary } \\
\text { gland, pituitary, snout } \\
\text { epidermis, thymus, thyroid, } \\
\text { trachea, bladder, }\end{array}$ & Metabolism. \\
\hline $\begin{array}{l}\text { Bromodomain } \\
\text { containing } 4 \\
(\mathrm{Brd} 4)\end{array}$ & NM_020508 & 17 & $\begin{array}{c}\text { Adipose tissue, bone, } \\
\text { bonemarrow, amygdala, } \\
\text { preoptic, hippocampus, } \\
\text { spinal cord'lower, embryo } \\
\text { day } 10.5 \text {, embryo day } 6.5 \text {, } \\
\text { embryo day } 7.5 \text {, embryo day } \\
\text { 8.5, embryo day } 9.5 \text {, ovary, } \\
\text { prostate, umbilical cord, } \\
\text { uterus, heart, small } \\
\text { intestine, B220+ B-cells, } \\
\text { CD4+Tcells, CD8+T cells, } \\
\text { lung, lymphnode, pancreas, } \\
\text { digits, snout epidermis, } \\
\text { thymus, }\end{array}$ & $\begin{array}{l}\text { Required maternally for } \\
\text { proper expression of } \\
\text { other homeotic genes } \\
\text { involved in pattern } \\
\text { formation, such as ubx. }\end{array}$ \\
\hline $\begin{array}{l}\text { Stimulated by } \\
\text { retinoic acid } 13 \\
\text { (Stra13) }\end{array}$ & NM_016665 & 11E2 & $\begin{array}{c}\text { Adipose tissue, } \\
\text { adrenalgland, bone, main } \\
\text { olfactory epithelium, embryo } \\
\text { day } 6.5, \text { embryo day } 9.5, \\
\text { fertilized egg, ovary, } \\
\text { prostate, testis, umbilical } \\
\text { cord, uterus, oocyte, large } \\
\text { intestine, B220+ B-cells, } \\
\text { CD4+ T cells, CD8+ T cells, } \\
\text { liver, lung, vomeronasal } \\
\text { organ, salivary gland, } \\
\text { tongue, pituitary, digits, } \\
\text { snout epidermis, spleen, } \\
\text { thymus, trachea, kidney. }\end{array}$ & ---- \\
\hline
\end{tabular}




\begin{tabular}{|c|c|c|c|c|}
\hline \multicolumn{5}{|c|}{ 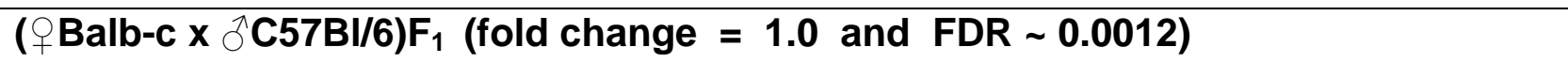 } \\
\hline Gene name & $\begin{array}{l}\text { GenBank } \\
\text { accession }\end{array}$ & Chromos & $\begin{array}{l}\text { Predominant } \\
\text { expression }\end{array}$ & $\begin{array}{l}\text { Molecular/biological } \\
\text { function }\end{array}$ \\
\hline $\begin{array}{l}\text { Ets2 repressor } \\
\text { factor } \\
\text { (Erf) }\end{array}$ & NM_010155 & 7 & $\begin{array}{c}\text { Brown fat, bonemarrow, } \\
\text { dorsal striatum, } \\
\text { hippocampus, blastocysts, } \\
\text { embryo day } 10.5 \text {, embryo } \\
\text { day } 6.5 \text {, embryo day } 7.5, \\
\text { embryo day } 8.5 \text {, embryo } \\
\text { day } 9.5, \text { fertilized egg, } \\
\text { mammary gland (lact), } \\
\text { ovary, placenta, heart, small } \\
\text { intestine, liver, skeletal } \\
\text { muscle, salivary gland, } \\
\text { pancreas, spleen, stomach, } \\
\text { thyroid, bladder }\end{array}$ & $\begin{array}{l}\text { Transcriptional } \\
\text { repressor (by } \\
\text { similarity). }\end{array}$ \\
\hline $\begin{array}{l}\text { RAB2, member } \\
\text { RAS oncogene } \\
\text { family } \\
\text { (Rab2) }\end{array}$ & NM_021518 & 4A1 & $\begin{array}{l}\text { Adrenal gland, amygdala, } \\
\text { frontal cortex, preoptic, } \\
\text { trigeminal, cerebellum, } \\
\text { cerebral cortex, dorsal root } \\
\text { ganglia, dorsal striatum, } \\
\text { hippocampus, } \\
\text { hypothalamus, main } \\
\text { olfactory ephitelium, } \\
\text { olfactory bulb, spinal cord } \\
\text { lower, spinal cord upper, } \\
\text { substantia nigra, fertilized } \\
\text { egg, ovary, prostate, oocyte, } \\
\text { large intestine, lung, skeletal } \\
\text { muscle, vomeronasal organ, } \\
\text { pituitary, digits, epidermis, } \\
\text { bladder, kidney, retina. }\end{array}$ & $\begin{array}{l}\text { Required for protein } \\
\text { transport from the } \\
\text { endoplasmic reticulum } \\
\text { to the golgi complex (by } \\
\text { similarity). }\end{array}$ \\
\hline $\begin{array}{c}\text { Membrane } \\
\text { associated DNA } \\
\text { binding protein } \\
\text { (Mnab) }\end{array}$ & XM_130233 & 2 & $\begin{array}{l}\text { Adrenal gland, amygdala, } \\
\text { frontal cortex, preoptic, } \\
\text { trigeminal, cerebellum, } \\
\text { cerebral cortex, dorsal root } \\
\text { ganglia, dorsal striatum, } \\
\text { hippocampus, } \\
\text { hypothalamus, main } \\
\text { olfactory ephitelium, } \\
\text { olfactory bulb, spinal cord } \\
\text { lower, substantia nigra, } \\
\text { embryo day } 10.5 \text {, ovary, } \\
\text { prostate, umbilical cord, } \\
\text { lung, skeletal muscle, } \\
\text { vomeronasal organ, tongue, } \\
\text { pituitary, digits, epidermis, } \\
\text { thymus, trachea, bladder, }\end{array}$ & Nucleic acid binding. \\
\hline $\begin{array}{l}\text { RAD51-like } 1 \text { (S. } \\
\text { cerevisiae) } \\
\text { (Rad51I1) }\end{array}$ & NM_009014 & $12 \mathrm{C} 3$ & $\begin{array}{l}\text { Brown fat, bonemarrow, } \\
\text { dorsal striatum, embryo day } \\
9.5, \text { fertilized egg, } \\
\text { mammary gland (lact), } \\
\text { ovary, placenta, testis, } \\
\text { uterus, B220+B-cells, } \\
\text { CD4+Tcells, salivary gland, } \\
\text { pancreas, spleen, stomach, } \\
\text { thyroid, trachea. }\end{array}$ & $\begin{array}{l}\text { DNA repair (by } \\
\text { similarity). }\end{array}$ \\
\hline
\end{tabular}




\begin{tabular}{|c|c|c|c|c|}
\hline $\begin{array}{c}\text { Small chemokine } \\
\text { (C-C motif) ligand } \\
11 \\
(\mathrm{C} \text { cl11) }\end{array}$ & NM_011330 & 11 & $\begin{array}{l}\text { Brown fat, adipose tissue, } \\
\text { trigeminal, ovary, prostate, } \\
\text { uterus, large intestine, small } \\
\text { intestine, lymphnode, } \\
\text { skeletal muscle, tongue, } \\
\text { digits, epidermis, snout } \\
\text { epidermis, stomach, thymus, } \\
\text { thyroid, trachea, bladder. }\end{array}$ & $\begin{array}{l}\text { Immune response by } \\
\text { eosinophils. }\end{array}$ \\
\hline $\begin{array}{l}\text { DEAD (Asp-Glu- } \\
\text { Ala-Asp) box } \\
\text { polypeptide } 21 \\
\text { (Ddx21) }\end{array}$ & NM_019553 & 10 & $\begin{array}{l}\text { Adipose tissue, adrenal } \\
\text { gland, bone, blastocysts, } \\
\text { embryo day } 10.5 \text {, embryo } \\
\text { day } 6.5 \text {, embryo day } 7.5, \\
\text { embryo day } 8.5 \text {, embryo } \\
\text { day } 9.5 \text {, mammary gland } \\
\text { (lact), ovary, prostate, } \\
\text { umbilical cord, uterus, larger } \\
\text { intestine, B220+B-cells, } \\
\text { CD4+Tcells, CD8+Tcells, } \\
\text { lung, lymphnode, salivary } \\
\text { gland, tongue, digits, } \\
\text { epidermis, spleen, thymus, } \\
\text { trachea, bladder }\end{array}$ & $\begin{array}{l}\text { Nucleic acid binding } \\
\text { RNA helicase/foldase } \\
\text { (by similarity). }\end{array}$ \\
\hline $\begin{array}{l}\text { Sodium channel } \\
\text { modifier } 1 \\
\text { (Scnm1) }\end{array}$ & NM_027013 & 3 & $\begin{array}{c}\text { Brown fat, frontal cortex, } \\
\text { preoptic, trigeminal, } \\
\text { hippocampus, hypothalamus, } \\
\text { main olfactory ephitelium, } \\
\text { spinal cord lower, substantia } \\
\text { nigra, blastocysts, embryo } \\
\text { day } 10.5 \text {, embryo day } 6.5 \text {, } \\
\text { embryo day } 7.5 \text {, embryo day } \\
\text { 9.5, ovary, testis, heart, } \\
\text { B220+B-cells, CD4+Tcells, } \\
\text { CD8+Tcells, tongue, pituitary, } \\
\text { digits, snout epidermis, } \\
\text { thymus, trachea. }\end{array}$ & $\begin{array}{c}\text { Ion channel activity and } \\
\text { RNA splicing. }\end{array}$ \\
\hline $\begin{array}{l}\text { Sialophorin } \\
\quad(\text { Spn) }\end{array}$ & NM_009259 & 7 & $\begin{array}{l}\text { Bone, bonemarrow, embryo } \\
\text { day } 10.5 \text {, embryo day } 6.5 \text {, } \\
\text { embryo day } 7.5 \text {, embryo } \\
\text { day } 9.5 \text {, placenta, B220+B- } \\
\text { cells, CD4+Tcells, } \\
\text { CD8+Tcells, lung, } \\
\text { lymphnode, spleen, thymus, } \\
\text { trachea. }\end{array}$ & $\begin{array}{l}\text { Negative regulatory } \\
\text { role in adaptive } \\
\text { immune response (by } \\
\text { similarity). }\end{array}$ \\
\hline $\begin{array}{c}\text { Adenosine } \\
\text { deaminase } \\
\text { (Ada) }\end{array}$ & NM_007398 & 2 & $\begin{array}{l}\text { Placenta, small intestine, } \\
\text { tongue, thymus, trachea. }\end{array}$ & $\begin{array}{c}\text { Immune response, } \\
\text { nucleotide metabolism. }\end{array}$ \\
\hline $\begin{array}{l}\text { Ecotropic viral } \\
\text { integration site } 2^{\mathrm{a}} \\
\text { (Evi2a) }\end{array}$ & NM_010161 & 11 & $\begin{array}{c}\text { Brown fat,bone, } \\
\text { bonemarrow, dorsal } \\
\text { striatum, hippocampus, } \\
\text { spinal cord upper, } \\
\text { blastocysts, embryo day } \\
10.5 \text {, embryo day } 6.5, \\
\text { embryo day } 7.5 \text {, embryo } \\
\text { day } 9.5, \text { mammary gland } \\
\text { (lact), oocyte, heart, } \\
\text { CD8+Tcells, liver, } \\
\text { lymphnode, pancreas, } \\
\text { epidermis, spleen, stomach, } \\
\text { thymus, thyroid, trachea. }\end{array}$ & --- \\
\hline
\end{tabular}




\begin{tabular}{|c|c|c|c|c|}
\hline $\begin{array}{c}\text { B-cell } \\
\text { leukemia/lymphom } \\
\text { a } 6 \\
(\mathrm{Bcl} 6)\end{array}$ & NM_009744 & 16 & $\begin{array}{l}\text { Adipose tissue, adrenal } \\
\text { gland, bone, cerebellum, } \\
\text { hippocampus, main olfactory } \\
\text { ephitelium, olfactory bulb, } \\
\text { spinal cord lower, spinal cord } \\
\text { upper, ovary, prostate, uterus, } \\
\text { B220+B-cells, lymphnode, } \\
\text { skeletal muscle, salivary } \\
\text { gland, digits, epidermis, snout } \\
\text { epidermis, thymus, trachea, } \\
\text { kidney, retina. }\end{array}$ & Transcription factor \\
\hline $\begin{array}{l}\text { Interleukin } 16 \\
\text { (II16) }\end{array}$ & NM_010551 & 7 & $\begin{array}{l}\text { Adipose tissue, cerebellum, } \\
\text { B220+B-cells, CD4+Tcells, } \\
\text { CD8+Tcells, lymphnode, } \\
\text { spleen, thymus, trachea. }\end{array}$ & $\begin{array}{l}\text { Cytokine activity, } \\
\text { immune cell } \\
\text { chemotaxis. }\end{array}$ \\
\hline $\begin{array}{l}\text { Chemokine (C-X-C } \\
\text { motif) ligand } 4 \\
\text { (Cxcl4) }\end{array}$ & NM_019932 & $5 \mathrm{E} 1$ & $\begin{array}{c}\text { Adipose tissue, bone, } \\
\text { bonemarrow, trigeminal, } \\
\text { ovary, umbilical cord, heart, } \\
\text { lung, skeletal muscle, } \\
\text { vomeronasal organ, tongue, } \\
\text { digits, epidermis, snout } \\
\text { epidermis, spleen, trachea, } \\
\text { bladder. }\end{array}$ & $\begin{array}{l}\text { Platelet factor } 4 \text {, is } \\
\text { released during platelet } \\
\text { aggregation. }\end{array}$ \\
\hline $\begin{array}{l}\text { Microtubule- } \\
\text { associated protein, } \\
\text { RP/EB family, } \\
\text { member 2 } \\
\text { (Mapre2) }\end{array}$ & NM_153058 & $18 \mathrm{~A} 2$ & $\begin{array}{c}\text { Brown fat, bonemarrow, } \\
\text { dorsal striatum, blastocysts, } \\
\text { embryo day } 10.5 \text {, embryo } \\
\text { day } 6.5 \text {, embryo day } 7.5, \\
\text { embryo day } 9.5 \text {, mammary } \\
\text { gland (lact), placenta, } \\
\text { prostate, heart, small } \\
\text { intestine, liver, lung, } \\
\text { lymphnode, skeletal muscle, } \\
\text { salivary gland, pancreas, } \\
\text { spleen, stomach, thyroid, } \\
\text { bladder. }\end{array}$ & $\begin{array}{l}\text { Microtubule binding } \\
\text { and protein binding. }\end{array}$ \\
\hline $\begin{array}{c}\text { WAP, } \\
\text { follistatin/kazal, } \\
\text { immunoglobulin, } \\
\text { kunitz and netrin } \\
\text { domain containing } \\
2 \\
\text { (Wfikkn2) }\end{array}$ & NM_181819 & 11D & $\begin{array}{l}\text { Adipose tissue, prostate, } \\
\text { umbilical cord, uterus, } \\
\text { CD4+Tcells, } \\
\text { CD8+Tcellslung, } \\
\text { lymphnode, longue, digits, } \\
\text { epidermis, thymus }\end{array}$ & $\begin{array}{l}\text { Alpha-1-microglobulin } \\
\text { occurs in many } \\
\text { physiological fluids } \\
\text { including plasma, urine } \\
\text { and cerebrospinal fluid } \\
\text { (by similarity). }\end{array}$ \\
\hline $\begin{array}{l}\text { Signal transducer } \\
\text { and activator of } \\
\text { transcription } 1 \\
\text { (Stat1) }\end{array}$ & NM_009283 & 1 & $\begin{array}{l}\text { Adipose tissue, adrenal } \\
\text { gland, bone, bonemarrow, } \\
\text { trigeminal, dorsal root } \\
\text { ganglia, ovary, uterus, } \\
\text { B220+B-cells, CD4+Tcells, } \\
\text { CD8+Tcells, lung, } \\
\text { lymphnode, pancreas, } \\
\text { spleen, thymus, thyroid, } \\
\text { trachea, }\end{array}$ & Transcription factor. \\
\hline $\begin{array}{l}\text { C-type lectin } \\
\text { domain family } 1 \text {, } \\
\text { member b } \\
(\text { Clec1b) } \\
(\text { Clec } 2)\end{array}$ & NM_019985 & $6 F 3$ & $\begin{array}{l}\text { Bone, bonemarrow, embryo } \\
\text { day } 10.5, \text { placenta, liver, } \\
\text { lymphnode, pancreas, } \\
\text { spleen, trachea. }\end{array}$ & $\begin{array}{l}\text { Cell surface receptor } \\
\text { linked signal } \\
\text { transduction. }\end{array}$ \\
\hline
\end{tabular}




\begin{tabular}{|c|c|c|c|c|}
\hline $\begin{array}{l}\text { Exportin, tRNA } \\
\text { (nuclear export } \\
\text { receptor for } \\
\text { tRNAs) } \\
\text { (Xpot) }\end{array}$ & XM_125902 & 10D3 & $\begin{array}{l}\text { Adrenal gland, amygdale, } \\
\text { frontal cortex, preoptic, } \\
\text { cerebellum, cerebral cortex, } \\
\text { dorsal root ganglia, } \\
\text { hippocampus, hypothalamus, } \\
\text { olfactory bulb, spinal cord } \\
\text { lower, spinal cord upper, } \\
\text { substantia nigra, } \\
\text { blastocysts, embryo day } 10.5, \\
\text { embryo day } 6.5 \text {, embryo day } \\
7.5, \text { embryo day } 9.5, \\
\text { mammary gland (lact), ovary, } \\
\text { prostate, umbilical cord, } \\
\text { uterus, lung, longue, digits, } \\
\text { thymus, trachea. }\end{array}$ & $\begin{array}{l}\text { Mediates nuclear } \\
\text { export of all tRNAs (by } \\
\text { similarity). }\end{array}$ \\
\hline $\begin{array}{l}\text { Ubiquitin-activating } \\
\text { enzyme E1, Chr X } \\
\text { (Ube1x) }\end{array}$ & NM_009457 & $\mathrm{X}$ & $\begin{array}{l}\text { Adrenal gland, preoptic, } \\
\text { trigeminal, cerebellum, } \\
\text { cerebral cortex, dorsal root } \\
\text { ganglia, olfactory bulb, } \\
\text { substantia nigra, } \\
\text { blastocysts, embryo day } \\
10.5 \text {, embryo day } 6.5, \\
\text { embryo day } 9.5, \text { fertilized } \\
\text { egg, ovary, prostate, uterus, } \\
\text { oocyte, CD4+Tcells, } \\
\text { longue, digits, snout } \\
\text { epidermis, thymus, trachea }\end{array}$ & ATP binding. \\
\hline $\begin{array}{c}\text { Activating } \\
\text { transcription factor } \\
4 \\
\text { (Atf4) }\end{array}$ & NM_009716 & 15 & $\begin{array}{l}\text { Adrenal gland, cerebellum, } \\
\text { main olfactory epithelium, } \\
\text { blastocysts, , embryo day } \\
6.5, \text { embryo day } 7.5, \\
\text { embryo day } 9.5, \text { placenta, } \\
\text { umbilical cord, uterus, } \\
\text { oocyte, large intestine, } \\
\text { B220+B-cells, CD4+Tcells, } \\
\text { lung, skeletal muscle, } \\
\text { vomeronasal organ, salivary } \\
\text { gland, tongue, pituitary, } \\
\text { digits, snout epidermis, } \\
\text { thymus, trachea, retina. }\end{array}$ & Transcription factor. \\
\hline $\begin{array}{c}\text { Zinc finger protein } \\
131 \\
(\mathrm{Zfp} 131)\end{array}$ & NM_028245 & 13 & $\begin{array}{c}\text { Adipose tissue, adrenal } \\
\text { gland, bone, bonemarrow, } \\
\text { amygdale, frontal cortex, } \\
\text { cerebellum, embryo day } 9.5, \\
\text { fertilized egg, ovary, uterus, } \\
\text { oocyte, large intestine, } \\
\text { B220+B-cells, CD4+Tcells, } \\
\text { CD8+Tcells, lung, } \\
\text { lymphnode, skeletal muscle, } \\
\text { digits, thymus, trachea. }\end{array}$ & $\begin{array}{l}\text { May be involved in } \\
\text { transcriptional } \\
\text { regulation. }\end{array}$ \\
\hline $\begin{array}{l}\text { RAB14, member } \\
\text { RAS oncogene } \\
\text { family } \\
\text { (Rab14) }\end{array}$ & NM_026697 & $2 \mathrm{~B}$ & $\begin{array}{l}\text { Adipose tissue, bone, } \\
\text { bonemarrow, preoptic, } \\
\text { blastocysts, ovary, umbilical } \\
\text { cord, lymphnode, longue, } \\
\text { digits, epidermis, snout } \\
\text { epidermis, thymus*, trachea. }\end{array}$ & $\begin{array}{l}\text { Required for protein } \\
\text { transport in the } \\
\text { secretory pathway. }\end{array}$ \\
\hline
\end{tabular}




\begin{tabular}{|c|c|c|c|c|}
\hline $\begin{array}{l}\text { Synaptophysin-like } \\
\text { protein } \\
\text { (Sypl) }\end{array}$ & NM_198710 & 12 & $\begin{array}{c}\text { Adipose tissue, } \\
\text { adrenalgland, bone, main } \\
\text { olfactory epithelium, spinal } \\
\text { cord'lower, spinal cord } \\
\text { upper, fertilized egg, ovary, } \\
\text { placenta, prostate, uterus, } \\
\text { oocyte, heart, large } \\
\text { intestine, small intestine, } \\
\text { B220+ B cells, lung, skeletal } \\
\text { muscle, vomeronasal organ, } \\
\text { salivary gland, tongue, } \\
\text { digits, epidermis, snout } \\
\text { epidermis, stomach, } \\
\text { trachea, bladder, kidney, } \\
\text { retina. }\end{array}$ & $\begin{array}{l}\text { Transport, transporter } \\
\text { activity. }\end{array}$ \\
\hline $\begin{array}{l}\text { WD repeat and } \\
\text { SOCS box- } \\
\text { containing } 2 \\
\text { (Wsb2) }\end{array}$ & NM_021539 & $5 F$ & $\begin{array}{l}\text { Adrenal gland, amygdale, } \\
\text { frontal cortex, preoptic, } \\
\text { trigeminal, cerebellum, } \\
\text { cerebral cortex, dorsal root } \\
\text { ganglia, dorsal striatum, } \\
\text { hippocampus, hypothalamus, } \\
\text { main olfactory ephitelium, } \\
\text { olfactory bulb, spinal cord } \\
\text { lower, spinal cord upper, } \\
\text { substantia nigra, ovary, } \\
\text { placenta, umbilical cord, } \\
\text { uterus, large intestine, } \\
\text { lymphnode, skeletal muscle, } \\
\text { vomeronasal organ, } \\
\text { pancreas, pituitary, spleen, } \\
\text { kidney. } \\
\end{array}$ & $\begin{array}{l}\text { Intracellular signaling } \\
\text { cascade }\end{array}$ \\
\hline $\begin{array}{c}\text { POU domain, } \\
\text { class } 2, \\
\text { associating factor } \\
1 \\
\text { (Pou2af1) }\end{array}$ & NM_011136 & 9 A5.3 & $\begin{array}{c}\text { Adipose tissue, bone, } \\
\text { bonemarrow, B220+B-cells, } \\
\text { CD4+Tcells, CD8+Tcells, } \\
\text { lymphnode, spleen, trachea. }\end{array}$ & $\begin{array}{l}\text { DNA binding, } \\
\text { regulation of } \\
\text { transcription. }\end{array}$ \\
\hline $\begin{array}{c}\text { Transformed } \\
\text { mouse } 3 T 3 \text { cell } \\
\text { double minute } 2 \\
(\mathrm{Mdm} 2)\end{array}$ & NM_010786 & 10 & $\begin{array}{l}\text { Adrenal gland, amygdale, } \\
\text { preoptic, spinal cord lower, } \\
\text { substantia nigra, } \\
\text { blastocysts, embryo day } \\
6.5 \text {, embryo day } 8.5, \\
\text { embryo day } 9.5 \text {, fertilized } \\
\text { egg, placenta, testis, } \\
\text { oocyte, B220+B-cells, } \\
\text { CD4+Tcells, CD8+Tcells, } \\
\text { lung, lymphnode, skeletal } \\
\text { muscle, vomeronasal organ, } \\
\text { thymus, trachea. }\end{array}$ & $\begin{array}{l}\text { Cell growth and/or } \\
\text { maintenance. }\end{array}$ \\
\hline $\begin{array}{l}\text { Interleukin } 4 \\
\quad \text { (II4) }\end{array}$ & NM_021283 & 11 & $\begin{array}{l}\text { Brown fat, bonemarrow, } \\
\text { dorsal striatum, } \\
\text { hippocampus, embryo day } \\
10.5, \text { embryo day } 7.5, \\
\text { embryo day } 9.5 \text {, fertilized } \\
\text { egg, mammary gland (lact), } \\
\text { placenta, testis, heart, large } \\
\text { intestine, small intestine, } \\
\text { liver, skeletal muscle, } \\
\text { salivary gland, longue, } \\
\text { pancreas, spleen, stomach, } \\
\text { thyroid, bladder, kidney. }\end{array}$ & $\begin{array}{l}\text { Participates in at least } \\
\text { several b-cell activation } \\
\text { processes as well as of } \\
\text { other cell types. }\end{array}$ \\
\hline
\end{tabular}




\begin{tabular}{|c|c|c|c|c|}
\hline $\begin{array}{c}\text { Protein O- } \\
\text { fucosyltransferase } \\
2 \\
\text { (Pofut2) }\end{array}$ & NM_030262 & $10 \mathrm{C} 1$ & $\begin{array}{l}\text { Brown fat, Adipose tissue, } \\
\text { adrenal gland, preoptic, } \\
\text { cerebellum, main olfactory } \\
\text { epithelium, embryo day } 6.5 \text {, } \\
\text { embryo day } 7.5 \text {, embryo } \\
\text { day } 8.5, \text { embryo day } 9.5, \\
\text { fertilized egg, ovary, } \\
\text { placenta, testis, umbilical } \\
\text { cord, uterus, oocyte, lung, } \\
\text { vomeronasal organ, } \\
\text { pituitary, snout epidermis. }\end{array}$ & $\begin{array}{l}\text { Carbohydrate } \\
\text { metabolism. }\end{array}$ \\
\hline $\begin{array}{l}\text { CD24a antigen } \\
(\mathrm{Cd} 24 \mathrm{a})\end{array}$ & NM_009846 & 10 & $\begin{array}{c}\text { Adipose tissue, bone, } \\
\text { bonemarrow, trigeminal, } \\
\text { dorsal root ganglia, main } \\
\text { olfactory epithelium, embryo } \\
\text { day } 10.5 \text {, embryo day } 8.5, \\
\text { embryo day } 9.5, \text { mammary } \\
\text { gland (lact), ovary, prostate, } \\
\text { uterus, large intestine, } \\
\text { B220+B-cells, lung, skeletal } \\
\text { muscle, , vomeronasal } \\
\text { organ, salivary gland, } \\
\text { longue, digits, spleen, } \\
\text { stomach, thymus, thyroid, } \\
\text { trachea, kidney, retina. }\end{array}$ & $\begin{array}{l}\text { May have a pivotal role } \\
\text { in cell differentiation. }\end{array}$ \\
\hline $\begin{array}{l}\text { Transcription } \\
\text { factor E2a } \\
\text { (Tcfe2a) }\end{array}$ & NM_011548 & 10 & $\begin{array}{l}\text { Adipose tissue, adrenal } \\
\text { gland, bone, bonemarrow, } \\
\text { cerebellum, main olfactory } \\
\text { epithelium, embryo day } \\
10.5 \text {, embryo day } 6.5 \text {, } \\
\text { embryo day } 7.5 \text {, embryo } \\
\text { day } 8.5 \text {, embryo day } 9.5, \\
\text { fertilized egg, ovary, } \\
\text { umbilical cord, uterus, } \\
\text { oocyte, B220+B-cells, } \\
\text { CD4+Tcells, CD8+Tcells, } \\
\text { lymphnode, pituitary, digits, } \\
\text { epidermis, snout epidermis, } \\
\text { spleen, thymus, trachea, } \\
\text { bladder. }\end{array}$ & Transcription factor. \\
\hline $\begin{array}{l}\text { Interferon-induced } \\
\text { protein with } \\
\text { tetratricopeptide } \\
\text { repeats } 2 \\
\text { (Ifit2) }\end{array}$ & NM_008332 & $19 \mathrm{C} 1$ & $\begin{array}{l}\text { Adipose tissue, adrenal } \\
\text { gland, bone, retina, } \\
\text { bonemarrow, trigeminal, } \\
\text { dorsal root ganglia, } \\
\text { hypothalamus, main } \\
\text { olfactory epithelium, } \\
\text { olfactory bulb, spinal cord } \\
\text { lower, substantia nigra, } \\
\text { ovary, placenta, prostate, } \\
\text { uterus, heart, large intestine, } \\
\text { B220+B-cells, CD4+Tcells, } \\
\text { CD8+Tcells, lung, } \\
\text { lymphnode, vomeronasal } \\
\text { organ, epidermis, spleen, } \\
\text { thymus, trachea, kidney. }\end{array}$ & Immune response \\
\hline
\end{tabular}




\begin{tabular}{|c|c|c|c|c|}
\hline $\begin{array}{l}\text { Cut-like } 1 \\
\text { (Drosophila) } \\
\text { (Cutil) }\end{array}$ & NM_009986 & 5 & $\begin{array}{l}\text { Brown fat, adrenalgland, } \\
\text { bonemarrow, frontal cortex, } \\
\text { preoptic, cerebellum, dorsal } \\
\text { striatum, main olfactory } \\
\text { epithelium, olfactory bulb, } \\
\text { spinal cord'lower, substantia } \\
\text { nigra, embryo day } 10.5, \\
\text { embryo day } 7.5, \text { embryo day } \\
8.5 \text {, embryo day } 9.5, \\
\text { fertilized egg, mammary } \\
\text { gland (lact), placenta, } \\
\text { umbilical cord, uterus, heart, } \\
\text { large intestine, small } \\
\text { intestine, liver, lung, skeletal } \\
\text { muscle, omeronasal organ, } \\
\text { salivary gland, tongue, } \\
\text { pancreas, digits, epidermis, } \\
\text { snout epidermis, spleen, } \\
\text { stomach, thymus, thyroid, } \\
\text { bladder, kidney, retina. }\end{array}$ & $\begin{array}{l}\text { Probably has a broad } \\
\text { role in mammalian } \\
\text { development as a } \\
\text { repressor of } \\
\text { developmentally } \\
\text { regulated gene } \\
\text { expression. }\end{array}$ \\
\hline $\begin{array}{c}\text { Histocompatibility } \\
\text { 2, complement } \\
\text { component factor } \\
\text { B } \\
\text { (H2-Bf })\end{array}$ & NM_008198 & 17 & $\begin{array}{c}\text { Adipose tissue, ovary, } \\
\text { uterus, large intestine, small } \\
\text { intestine, liver, lymphnode, } \\
\text { digits, epidermis, snout } \\
\text { epidermis, spleen, trachea, } \\
\text { kidney. }\end{array}$ & $\begin{array}{l}\text { Factor B which is part } \\
\text { of the alternate } \\
\text { pathway of the } \\
\text { complement system. }\end{array}$ \\
\hline $\begin{array}{l}\text { Fanconi anemia, } \\
\text { complementation } \\
\text { group G } \\
\text { (Fancg) }\end{array}$ & NM_053081 & 4B1 & $\begin{array}{l}\text { Bone, bonemarrow, fertilized } \\
\text { egg, testis, oocyte, B220+B- } \\
\text { cells, CD4+Tcells, } \\
\text { CD8+Tcells, salivary gland, } \\
\text { longue, digits, snout } \\
\text { epidermis, thymus, trachea. }\end{array}$ & $\begin{array}{l}\text { Binding,DNA repair, } \\
\text { response to DNA } \\
\text { damage stimulus, } \\
\text { response to radiation, } \\
\text { spermatid } \\
\text { development. } \\
\end{array}$ \\
\hline $\begin{array}{l}\text { Ras homolog gene } \\
\text { family, member A } \\
\text { (Rhoa) }\end{array}$ & NM_016802 & 9 & $\begin{array}{l}\text { Adipose tissue, adrenal } \\
\text { gland, bone, dorsal root } \\
\text { ganglia, main olfactory } \\
\text { epithelium, embryo day } 10.5 \text {, } \\
\text { embryo day } 6.5 \text {, embryo day } \\
7.5 \text {, embryo day } 8.5 \text {, } \\
\text { embryo day } 9.5 \text {, ovary, } \\
\text { prostate, umbilical cord, } \\
\text { uterus, heart, large intestine, } \\
\text { small intestine, B220+B-cells, } \\
\text { CD4+Tcells, CD8+Tcells, } \\
\text { lung, vomeronasal organ, } \\
\text { digits, snout epidermis, } \\
\text { stomach, thymus, trachea, } \\
\text { bladder, kidney. }\end{array}$ & $\begin{array}{l}\text { Regulates a signal } \\
\text { transduction pathway } \\
\text { linking plasma } \\
\text { membrane receptors to } \\
\text { the assembly of focal } \\
\text { adhesions and actin } \\
\text { stress fibers. }\end{array}$ \\
\hline $\begin{array}{l}\text { Interferon-induced } \\
\text { protein with } \\
\text { tetratricopeptide } \\
\text { repeats } 1 \\
\text { (Ifit1) }\end{array}$ & NM_008331 & $19 \mathrm{C} 1$ & $\begin{array}{l}\text { Brown fat, Adipose tissue, } \\
\text { adrenal gland, bone, } \\
\text { bonemarrow, trigeminal, } \\
\text { dorsal root ganglia, main } \\
\text { olfactory epithelium, ovary, } \\
\text { placenta, prostate, uterus, } \\
\text { heart, large intestine, small } \\
\text { intestine, CD4+Tcells, } \\
\text { CD8+Tcells, liver, lung, } \\
\text { lymphnode, vomeronasal } \\
\text { organ, longue, pancreas, } \\
\text { epidermis, spleen, thymus, } \\
\text { trachea, bladder, retina. }\end{array}$ & Immune response. \\
\hline
\end{tabular}




\begin{tabular}{|c|c|c|c|c|}
\hline $\begin{array}{l}\text { Growth factor } \\
\text { receptor bound } \\
\text { protein } 2 \\
\text { (Grb2) }\end{array}$ & NM_008163 & 11 & $\begin{array}{l}\text { Bone, bonemarrow, preoptic, } \\
\text { cerebellum, cerebral cortex, } \\
\text { dorsal root ganglia, dorsal } \\
\text { striatum, hippocampus, } \\
\text { hypothalamus, olfactory bulb, } \\
\text { spinal cord'lower, substantia } \\
\text { nigra, embryo day } 10.5 \text {, } \\
\text { embryo day } 6.5 \text {, embryo day } \\
\text { 7.5, embryo day } 8.5 \text {, embryo } \\
\text { day } 9.5 \text {, heart, B220+ B cells, } \\
\text { CD4+ T cells, CD8+ T cells, } \\
\text { Iymphnode, tongue, } \\
\text { epidermis, snout epidermis }\end{array}$ & $\begin{array}{l}\text { MAPKKK cascade, } \\
\text { protein binding, Ras } \\
\text { protein signal } \\
\text { transduction, SH3/SH2 } \\
\text { adaptor activity }\end{array}$ \\
\hline $\begin{array}{c}\text { histamine receptor } \\
\text { H } 3 \\
\text { (Hrh3) }\end{array}$ & NM_133849 & $2 \mathrm{H} 4$ & $\begin{array}{c}\text { Bone, amygdale, frontal } \\
\text { cortex, preoptic, trigeminal, } \\
\text { cerebellum, córtex cerebral, } \\
\text { dorsal striatum, } \\
\text { hippocampus, hypothalamus, } \\
\text { olfactory bulb, spinal cord } \\
\text { lower, spinal cord upper, } \\
\text { substantia nigra embryo day } \\
7.5 \text {, embryo day } 9.5, \\
\text { placenta, lung, salivary gland, } \\
\text { pancreas, pituitary, spleen, } \\
\text { stomach, thyroid, retina. }\end{array}$ & $\begin{array}{l}\text { The } \mathrm{H} 3 \text { subclass of } \\
\text { histamine receptors } \\
\text { could mediate the } \\
\text { histamine signals in } \\
\text { CNS and peripheral } \\
\text { nervous system (by } \\
\text { similarity). }\end{array}$ \\
\hline $\begin{array}{l}\text { Tumor necrosis } \\
\text { factor receptor } \\
\text { superfamily, } \\
\text { member } 4 \\
\text { (Tnfrsf4) }\end{array}$ & NM_009452 & 1 & $\begin{array}{c}\text { Adipose tissue, main } \\
\text { olfactory epithelium, testis, } \\
\text { heart, small intestine, } \\
\text { B220+B-cells, CD4+Tcells, } \\
\text { lymphnode,, skeletal } \\
\text { muscle, epidermis, snout } \\
\text { epidermis, trachea, kidney. }\end{array}$ & $\begin{array}{l}\text { Cellular defense } \\
\text { response,inflammatory } \\
\text { response. }\end{array}$ \\
\hline $\begin{array}{l}\text { Wiskott-Aldrich } \\
\text { syndrome protein } \\
\text { interacting protein } \\
\text { (Waspip) }\end{array}$ & NM_153138 & 2 & $\begin{array}{c}\text { Adipose tissue, bone, } \\
\text { bonemarrow, dorsal root } \\
\text { ganglia, spinal cord lower, } \\
\text { blastocysts, embryo day } \\
\text { 10.5, mammary gland (lact), } \\
\text { umbilical cord, uterus, heart, } \\
\text { B220+B-cells, CD4+Tcells, } \\
\text { CD8+Tcells, lung, } \\
\text { lymphnode, vomeronasal } \\
\text { organ, longue, digits, snout } \\
\text { epidermis, spleen, thymus, } \\
\text { trachea, bladder. }\end{array}$ & $\begin{array}{l}\text { Actin binding, actin } \\
\text { filament-based } \\
\text { movement. }\end{array}$ \\
\hline $\begin{array}{l}\text { BCL2/adenovirus } \\
\text { E1B 19kDa- } \\
\text { interacting protein } \\
\text { 1, NIP3 } \\
\text { (Bnip3) }\end{array}$ & NM_009760 & $7 F 5$ & $\begin{array}{l}\text { Brown fat, Adipose tissue, } \\
\text { adrenal gland, frontal cortex, } \\
\text { trigeminal, cerebral cortex, } \\
\text { dorsal root ganglia, } \\
\text { hypothalamus, spinal cord } \\
\text { lower, spinal cord upper, } \\
\text { substantia nigra, } \\
\text { blastocysts, embryo day } 6.5 \text {, } \\
\text { embryo day } 8.5 \text {, ferlized } \\
\text { egg, ovary, placenta, } \\
\text { prostate, umbilical cord, } \\
\text { oocyte, heart, liver, skeletal } \\
\text { muscle, vomeronasal organ, } \\
\text { longue, pituitary, epidermis, } \\
\text { trachea, kidney. }\end{array}$ & $\begin{array}{l}\text { Binds to the adenovirus } \\
\text { e1b } 19 \text { kda protein or to } \\
\text { bcl-2. may play a role in } \\
\text { repartitioning calcium } \\
\text { between the two major } \\
\text { intracellular calcium } \\
\text { stores in association } \\
\text { with the } 19 \text { kda or bcl- } 2 \\
\text { proteins. }\end{array}$ \\
\hline
\end{tabular}




\begin{tabular}{|c|c|c|c|c|}
\hline $\begin{array}{c}\text { PTK2 protein } \\
\text { tyrosine kinase } 2 \\
\text { beta } \\
\text { (Ptk2b) }\end{array}$ & NM_172498 & 14 & $\begin{array}{l}\text { Adipose tissue, bone, } \\
\text { bonemarrow, amygdale, } \\
\text { frontal cortex, cerebral } \\
\text { cortex, dorsal striatum, } \\
\text { hippocampus, olfactory } \\
\text { bulb, large intestine, } \\
\text { B220+B-cells, CD4+Tcells, } \\
\text { CD8+Tcells, lymphnode, } \\
\text { spleen, thymus, trachea. }\end{array}$ & $\begin{array}{l}\text { Involved in calcium } \\
\text { induced regulation of } \\
\text { ion channel and } \\
\text { activation of the map } \\
\text { kinase signaling } \\
\text { pathway. }\end{array}$ \\
\hline $\begin{array}{l}\text { SMT3 suppressor } \\
\text { of mif two } 3 \\
\text { homolog } 3 \text { (yeast) } \\
\text { (Sumo3) }\end{array}$ & NM_019929 & 10 & $\begin{array}{l}\text { Bone, amygdale, frontal cortex, } \\
\text { preoptic, cerebellum, } \\
\text { hypothalamus, main olfactory } \\
\text { epithelium, olfactory bulb, spinal } \\
\text { cord lower, substantia nigra, } \\
\text { blastocysts, embryo day } 6.5 \text {, } \\
\text { embryo day } 8.5 \text {, embryo day } \\
9.5 \text {, embryo day } 10.5 \text { ferlized } \\
\text { egg, ovary, prostate, umbilical } \\
\text { cord, uterus, oocyte, } \\
\text { vomeronasal organ, pituitary, } \\
\text { digits, snout epidermis, thymus, } \\
\text { trachea, retina. }\end{array}$ & $\begin{array}{l}\text { Protein modification } \\
\text { ubiquitin cycle }\end{array}$ \\
\hline $\begin{array}{l}\text { tumor necrosis } \\
\text { factor receptor } \\
\text { superfamily, } \\
\text { member } 13 \mathrm{~b} \\
\text { (Tnfrsf13b) }\end{array}$ & NM_021349 & 11B2 & $\begin{array}{c}\text { Adipose tissue, bone, } \\
\text { bonemarrow, B220+B-cells, } \\
\text { CD4+Tcells, CD8+Tcells, } \\
\text { lung, lymphnode, spleen, } \\
\text { thymus, trachea. }\end{array}$ & $\begin{array}{c}\text { B cell homeostasis, } \\
\text { immune response, } \\
\text { negative regulation of B } \\
\text { cell proliferation, }\end{array}$ \\
\hline $\begin{array}{l}\text { Non-catalytic } \\
\text { region of tyrosine } \\
\text { kinase adaptor } \\
\text { protein } 2 \\
\text { (Nck2) }\end{array}$ & NM_010879 & $1 \mathrm{C} 1$ & $\begin{array}{l}\text { Adipose tissue, adrenal } \\
\text { gland, cerebral cortex, } \\
\text { hippocampus, main } \\
\text { olfactory epithelium, } \\
\text { olfactory bulb, blastocysts, } \\
\text { embryo day } 9.5 \text {, embryo day } \\
\text { 10.5, ovary, placenta, } \\
\text { prostate, umbilical cord, } \\
\text { uterus, heart, large intestine, } \\
\text { small intestine, CD4+Tcells, } \\
\text { CD8+Tcells, lung, } \\
\text { vomeronasal organ, tongue, } \\
\text { snout epidermis, stomach, } \\
\text { thymus, trachea, bladder. }\end{array}$ & $\begin{array}{l}\text { Actin filament } \\
\text { organization, cell } \\
\text { migration, epidermal } \\
\text { growth factor receptor } \\
\text { signaling pathway. }\end{array}$ \\
\hline $\begin{array}{c}\text { T-cell receptor } \\
\text { gamma, variable } 4 \\
\text { (Tcrg-V4) }\end{array}$ & Z12299.1 & 13 & $\begin{array}{l}\text { Brown fat, Adipose tissue, } \\
\text { bonemarrow, dorsal } \\
\text { striatum, heart, large } \\
\text { intestine, small intestine, } \\
\text { CD4+Tcells, CD8+Tcells, } \\
\text { liver, lymphnode, epidermis, } \\
\text { spleen, thymus, trachea. }\end{array}$ & $\begin{array}{l}\text { Cellular defense } \\
\text { response }\end{array}$ \\
\hline $\begin{array}{l}\text { F-box protein } 45 \\
\text { (Fbxo45) }\end{array}$ & NM_173439 & 16B2 & $\begin{array}{l}\text { Adipose tissue, adrenal gland, } \\
\text { bone, amygdala, frontal cortex } \\
\text { trigeminal, cerebral cortex, } \\
\text { cerebellum, dorsal root } \\
\text { ganglia, hippocampus, main } \\
\text { olfactory epithelium, olfactory } \\
\text { bulb, spinal cord lower, } \\
\text { substantia nigra, blastocysts, } \\
\text { embryo day } 9.5 \text {, embryo day } \\
10.5 \text {, ovary, heart, skeletal } \\
\text { muscle vomeronasal organ, } \\
\text { tongue, pituitary, digits, }\end{array}$ & Ubiquitin cycle \\
\hline
\end{tabular}




\begin{tabular}{|c|c|c|c|c|}
\hline $\begin{array}{l}\text { Protein kinase, } \\
\text { interferon inducible } \\
\text { double stranded } \\
\text { RNA dependent } \\
\text { activator } \\
\text { (Prkra) }\end{array}$ & NM_011871 & $2 \mathrm{C} 3$ & $\begin{array}{l}\text { Adipose tissue, adrenal } \\
\text { gland, bone, preoptic, } \\
\text { trigeminal, dorsal root } \\
\text { ganglia, hypotalamus, spinal } \\
\text { cord upper, spinal cord } \\
\text { lower, substantia nigra, } \\
\text { embryo day } 7.5 \text {, embryo day } \\
8.5 \text {, embryo day } 9.5, \\
\text { embryo day } 10.5 \text {, ovary, } \\
\text { testis, umbilical cord, } \\
\text { uterus, heart, large intestine, } \\
\text { small intestine, liver, lung, } \\
\text { pituitary, stomach, trachea, } \\
\text { bladder, kidney, retina. }\end{array}$ & $\begin{array}{c}\text { Double-stranded RNA } \\
\text { binding, kinase activity, } \\
\text { protein amino acid } \\
\text { phosphorylation. }\end{array}$ \\
\hline $\begin{array}{l}\text { Genetic } \\
\text { suppressor } \\
\text { element } 1 \\
\text { (Gse1) }\end{array}$ & NM_198671 & $8 \mathrm{E} 1$ & $\begin{array}{c}\text { bone, bonemarrow, } \\
\text { amygdale, preoptic, } \\
\text { cerebellum, cerebral cortex, } \\
\text { dorsal striatum, } \\
\text { hippocampus, hypotalamus, } \\
\text { main olfactory epithelium, } \\
\text { olfactory bulb, spinal cord } \\
\text { lower, substantia nigra, } \\
\text { blastocysts, embryo day } \\
\text { 10.5, embryo day embryo } \\
\text { day 9.5, prostate, oocyte, } \\
\text { large intestine, small } \\
\text { intestine, B220+B-cells, } \\
\text { CD4+Tcells, lung, } \\
\text { lymphnode, pituitary, digits, } \\
\text { snout epidermis, thymus, } \\
\text { bladder, retina. }\end{array}$ & --- \\
\hline $\begin{array}{c}\text { Janus kinase } 1 \\
\text { (Jak1) }\end{array}$ & NM_146145 & 4 & $\begin{array}{l}\text { Brown fat, Adipose tissue, } \\
\text { bone, amygdale, frontal } \\
\text { cortex, trigeminal, } \\
\text { cerebellum, dorsal striatum, } \\
\text { hypotalamus, spinal cord } \\
\text { lower, embryo day } 7.5, \\
\text { fertilized egg, mammary } \\
\text { gland, placenta, uterus, } \\
\text { oocyte, heart, B220+B-cells, } \\
\text { liver, lymphnode, salivary } \\
\text { gland, pancreas, digits, } \\
\text { epidermis, spleen, thymus, } \\
\text { thyroid. }\end{array}$ & $\begin{array}{l}\text { Tyrosine kinase of the } \\
\text { non-receptor type, } \\
\text { involved in the ifn- } \\
\text { alpha/beta/gamma } \\
\text { signal pathway. }\end{array}$ \\
\hline $\begin{array}{c}\text { transportin } 2 \\
\text { (importin } 3, \\
\text { karyopherin beta } \\
2 \mathrm{~b}) \\
(\text { Tnpo2) }\end{array}$ & NM_145390 & $8 \mathrm{C} 2$ & $\begin{array}{l}\text { Amygdale, frontal cortex, } \\
\text { preoptic, trigeminal, } \\
\text { cerebellum, cerebral cortex, } \\
\text { dorsal root ganglia, dorsal } \\
\text { striatum, hippocampus, } \\
\text { hypotalamus, main olfactory } \\
\text { epithelium, olfactory bulb, } \\
\text { spinal cord upper, spinal } \\
\text { cord lower, substantia } \\
\text { nigra, blastocysts, embryo } \\
\text { day } 6.5, \text { embryo day } 7.5 \text {, } \\
\text { embryo day } 9.5 \text {, ovary, } \\
\text { prostate, vomeronasal } \\
\text { organ, tongue, digits, snout } \\
\text { epidermis, thymus. }\end{array}$ & $\begin{array}{l}\text { Required for import of } \\
\text { mRNA binding proteins. }\end{array}$ \\
\hline
\end{tabular}




\begin{tabular}{|c|c|c|c|c|}
\hline $\begin{array}{c}\text { V-rel } \\
\text { reticuloendothelios } \\
\text { is viral oncogene } \\
\text { homolog A (avian) } \\
\text { (Rela) }\end{array}$ & NM_009045 & 19 & $\begin{array}{l}\text { Adipose tissue, adrenal } \\
\text { gland, bone, cerebellum, } \\
\text { main olfactory epithelium, } \\
\text { fertilized egg, ovary, } \\
\text { placenta, prostate, testis, } \\
\text { umbilical cord, uterus, } \\
\text { oocyte, B220+B-cells, } \\
\text { CD4+Tcells, CD8+Tcells, } \\
\text { lung, lymphnode, } \\
\text { vomeronasal organ, tongue, } \\
\text { pituitary, digits, epidermis, } \\
\text { snout epidermis, spleen, } \\
\text { thymus, trachea, bladder, } \\
\text { retina. }\end{array}$ & $\begin{array}{l}\text { Activation of NF- } \\
\text { kappaB transcription } \\
\text { factor. }\end{array}$ \\
\hline $\begin{array}{c}\text { Pyruvate } \\
\text { dehydrogenase } \\
\text { kinase, isoenzyme } \\
2 \\
\text { (Pdk2) }\end{array}$ & NM_133667 & 11 & $\begin{array}{l}\text { Brown fat, Adipose tissue, } \\
\text { amygdala, frontal cortex, } \\
\text { preoptic, cerebellum, } \\
\text { cerebral cortex, } \\
\text { hippocampus, hypotalamus, } \\
\text { main olfactory epithelium, } \\
\text { olfactory bulb, spinal cord } \\
\text { upper, spinal cord lower, } \\
\text { substantia nigra, prostate, } \\
\text { testis, heart, large intestine, } \\
\text { small intestine, lung, skeletal } \\
\text { muscle, vomeronasal organ, } \\
\text { tongue, epidermis, snout } \\
\text { epidermis, stomach, thymus, } \\
\text { thyroid, kidney. }\end{array}$ & $\begin{array}{l}\text { Regulation of glucose } \\
\text { metabolism. }\end{array}$ \\
\hline $\begin{array}{c}\text { Toll-like receptor } 4 \\
\text { (TIr4) }\end{array}$ & NM_021297 & 4 & $\begin{array}{l}\text { Brown fat, Adipose tissue, } \\
\text { bone, bonemarrow, main } \\
\text { olfactory epithelium, } \\
\text { mammary gland, prostate, } \\
\text { umbilical cord, uterus, } \\
\text { heart, large intestine, } \\
\text { B220+B-cells, liver, lung, } \\
\text { lymphnode, skeletal muscle, } \\
\text { vomeronasal organ, salivary } \\
\text { gland, tongue, pancreas, } \\
\text { digits, epidermis, spleen, } \\
\text { stomach, thyroid, trachea, } \\
\text { bladder. }\end{array}$ & $\begin{array}{c}\text { Activation of NF- } \\
\text { kappaB-inducing } \\
\text { kinase, catalytic } \\
\text { activity, I-kappaB } \\
\text { kinase/NF-kappaB } \\
\text { cascade, immune } \\
\text { response, inflammatory } \\
\text { response. }\end{array}$ \\
\hline $\begin{array}{c}\text { zinc finger protein } \\
143 \\
(\mathrm{Zfp} 143)\end{array}$ & NM_009281 & 7 & $\begin{array}{c}\text { Brown fat, Adipose tissue, } \\
\text { bone, bonemarrow, } \\
\text { cerebellum, main olfactory } \\
\text { epithelium, embryo day } \\
10.5 \text {, embryo day } 6.5, \\
\text { embryo day } 7.5 \text {, embryo day } \\
8.5 \text {, embryo day } 9.5, \\
\text { fertilized egg, ovary, testis, } \\
\text { umbilical cord, uterus, } \\
\text { oocyte, heart, B220+B-cells, } \\
\text { CD4+Tcells, CD8+Tcells, } \\
\text { lymphnode, skeletal muscle, } \\
\text { vomeronasal organ, salivary } \\
\text { gland, digits, snout } \\
\text { epidermis, spleen, thymus, } \\
\text { thyroid, trachea. }\end{array}$ & $\begin{array}{l}\text { Transcriptional } \\
\text { activator. binds to the } \\
\text { sph motif of small } \\
\text { nuclear rna (snRNA) } \\
\text { gene promoters. }\end{array}$ \\
\hline
\end{tabular}




\begin{tabular}{|c|c|c|c|c|}
\hline $\begin{array}{l}\text { Interleukin } 2 \\
\text { receptor, gamma } \\
\text { chain } \\
\text { (II2rg) }\end{array}$ & NM_013563 & $x$ & $\begin{array}{c}\text { Adipose tissue, bone, } \\
\text { bonemarrow, embryo day } \\
6.5 \text {, embryo day } 7.5 \text {, heart, } \\
\text { B220+B-cells, CD4+Tcells, } \\
\text { CD8+Tcells, lung, } \\
\text { lymphnode, skeletal muscle, } \\
\text { epidermis, spleen, thymus, } \\
\text { trachea. }\end{array}$ & $\begin{array}{l}\text { Cell surface receptor } \\
\text { linked signal } \\
\text { transduction. }\end{array}$ \\
\hline $\begin{array}{c}\text { UDP- } \\
\text { GlcNAc:betaGal } \\
\text { beta-1,3-N- } \\
\text { acetylglucosaminyl } \\
\text { transferase } 1 \\
\text { (B3gnt1) }\end{array}$ & NM_016888 & 11 & $\begin{array}{l}\text { Adipose tissue, adrenal } \\
\text { gland, bone, amygdale, } \\
\text { frontal cortex, trigeminal, } \\
\text { dorsal root ganglia, dorsal } \\
\text { striatum, hypotalamus, } \\
\text { main olfactory epithelium, } \\
\text { embryo day 6.5, fertilized } \\
\text { egg, ovary, prostate, } \\
\text { uterus, oocyte, large } \\
\text { intestine, small intestine, } \\
\text { B220+B-cells, CD4+Tcells, } \\
\text { CD8+Tcells, lung, } \\
\text { lymphnode, vomeronasal } \\
\text { organ, pituitary, digits, } \\
\text { snout epidermis, stomach, } \\
\text { thymus, trachea, bladder, } \\
\text { kidney. }\end{array}$ & $\begin{array}{c}\text { Axon guidance, } \\
\text { galactosyltransferase } \\
\text { activity, manganese ion } \\
\text { binding, protein amino } \\
\text { acid glycosylation, } \\
\text { sensory perception of } \\
\text { smell. }\end{array}$ \\
\hline $\begin{array}{c}\text { splicing factor } 3 b \text {, } \\
\text { subunit } 1 \\
\text { (Sf3b1) }\end{array}$ & NM_031179 & 1 & $\begin{array}{l}\text { Adipose tissue, adrenal } \\
\text { gland, bonemarrow, } \\
\text { amygdale, frontal cortex, } \\
\text { preoptic, trigeminal, } \\
\text { cerebellum, cerebral cortex, } \\
\text { dorsal striatum, } \\
\text { hippocampus, hypotalamus, } \\
\text { main olfactory epithelium, } \\
\text { olfactory bulb, spinal cord } \\
\text { upper, spinal cord lower, } \\
\text { substantia nigra, embryo } \\
\text { day } 10.5, \text { embryo day } 6.5, \\
\text { embryo day } 8.5 \text {, embryo } \\
\text { day } 9.5 \text {, fertilized egg, } \\
\text { ovary, umbilical cord, } \\
\text { uterus, oocyte, heart, } \\
\text { B220+B-cells, CD4+Tcells, } \\
\text { lung, pituitary, thymus, } \\
\text { trachea, bladder, kidney, } \\
\text { retina. }\end{array}$ & $\begin{array}{c}\text { Subunit of the splicing } \\
\text { factor sf3b required for } \\
\text { 'a' complex assembly } \\
\text { formed by the stable } \\
\text { binding of u2 snrnp to } \\
\text { the branchpoint } \\
\text { sequence (bps) in pre- } \\
\text { mRNA. }\end{array}$ \\
\hline $\begin{array}{l}\text { lymphoid enhancer } \\
\text { binding factor } 1 \\
\text { (Lef1) }\end{array}$ & NM_010703 & 3 & $\begin{array}{l}\text { Brown fat, bonemarrow, } \\
\text { blastocysts, embryo day } \\
\text { 10.5, embryo day } 6.5, \\
\text { embryo day } 7.5 \text {, embryo day } \\
8.5 \text {, embryo day } 9.5, \\
\text { fertilized egg, mammary } \\
\text { gland, placenta, prostate, } \\
\text { testis, umbilical cord, heart, } \\
\text { small intestine, B220+B- } \\
\text { cells, CD4+Tcells, } \\
\text { CD8+Tcells, liver, } \\
\text { lymphnode, skeletal muscle, } \\
\text { salivary gland, pancreas, } \\
\text { spleen, stomach, thymus, } \\
\text { thyroid, bladder, kidney. }\end{array}$ & $\begin{array}{c}\text { Transcriptional } \\
\text { activator. }\end{array}$ \\
\hline
\end{tabular}




\begin{tabular}{|c|c|c|c|c|}
\hline $\begin{array}{c}\text { solute carrier } \\
\text { family } 12, \text { member } \\
6 \\
(\text { Slc12a6) }\end{array}$ & NM_133649 & $2 \mathrm{E} 3$ & $\begin{array}{l}\text { Brown fat, bonemarrow, } \\
\text { dorsal striatum, } \\
\text { hippocampus, hypotalamus, } \\
\text { olfactory bulb, substantia } \\
\text { nigra, blastocysts, embryo } \\
\text { day } 10.5 \text {, embryo day } 6.5 \text {, } \\
\text { embryo day } 7.5 \text {, embryo day } \\
8.5 \text {, embryo day } 9.5, \\
\text { fertilized egg, mammary } \\
\text { gland, placenta, testis, } \\
\text { oocyte, heart, large } \\
\text { intestine, small intestine, } \\
\text { B220+B-cells, CD4+Tcells, } \\
\text { liver, lymphnode, skeletal } \\
\text { muscle, salivary gland, } \\
\text { pancreas, epidermis, } \\
\text { spleen, stomach, thymus, } \\
\text { thyroid, bladder, kidney. }\end{array}$ & Amino acid transport. \\
\hline $\begin{array}{l}\text { angio-associated } \\
\text { migratory protein } \\
\text { (Aamp) }\end{array}$ & NM_146110 & $1 \mathrm{C} 4$ & $\begin{array}{c}\text { Adipose tissue, adrenal } \\
\text { gland, amygdale, preoptic, } \\
\text { cerebellum, cerebral cortex, } \\
\text { dorsal root ganglia, } \\
\text { hippocampus, hypotalamus, } \\
\text { main olfactory epithelium, } \\
\text { olfactory bulb, spinal cord } \\
\text { lower, substantia nigra, } \\
\text { embryo day } 6.5 \text {, ovary, } \\
\text { placenta, prostate, testis, } \\
\text { uterus, B220+B-cells, } \\
\text { CD4+Tcells, CD8+Tcells, } \\
\text { lymphnode, vomeronasal } \\
\text { organ, pituitary, digits, } \\
\text { snout epidermis, thymus, } \\
\text { bladder, kidney. }\end{array}$ & --- \\
\hline $\begin{array}{l}\text { Nuclear factor of } \\
\text { activated T-cells, } \\
\text { cytoplasmic, } \\
\text { calcineurin- } \\
\text { dependent } 1 \\
\text { (Nfact1) }\end{array}$ & NM_016791 & 18 & $\begin{array}{l}\text { Brown fat, Adipose tissue, } \\
\text { bone, bonemarrow, main } \\
\text { olfactory epithelium, } \\
\text { fertilized egg, umbilical cord, } \\
\text { B220+B-cells, CD4+Tcells, } \\
\text { CD8+Tcells, lung, } \\
\text { lymphnode, skeletal muscle, } \\
\text { vomeronasal organ, salivary } \\
\text { gland, tongue, pancreas, } \\
\text { digits, epidermis, snout } \\
\text { epidermis, spleen, stomach, } \\
\text { thymus, thyroid, trachea. }\end{array}$ & $\begin{array}{l}\text { Plays a role in the } \\
\text { inducible expression of } \\
\text { cytokine genes in t cells } \\
\text { (by similarity). }\end{array}$ \\
\hline $\begin{array}{l}\text { actin-binding LIM } \\
\text { protein } 1 \\
\text { (Ablim1) }\end{array}$ & NM_178688 & 19 & $\begin{array}{l}\text { Brown fat, Adipose tissue, } \\
\text { amygdale, preoptic, } \\
\text { trigeminal, cerebellum, dorsal } \\
\text { root ganglia, olfactory bulb, } \\
\text { spinal cord lower, substantia } \\
\text { nigra, ovary, umbilical cord, } \\
\text { heart, large intestine, } \\
\text { B220+B-cells, CD4+Tcells, } \\
\text { CD8+Tcells, lung, } \\
\text { lymphnode, vomeronasal } \\
\text { organ, tongue, digits, } \\
\text { epidermis, snout epidermis, } \\
\text { spleen, stomach, thymus, } \\
\text { thyroid, trachea, retina. }\end{array}$ & $\begin{array}{l}\text { Actin binding, axon } \\
\text { guidance, cytoskeleton } \\
\text { organization and } \\
\text { biogenesis, metal ion } \\
\text { binding, zinc ion } \\
\text { binding. }\end{array}$ \\
\hline
\end{tabular}




\begin{tabular}{|c|c|c|c|c|}
\hline $\begin{array}{c}\text { DNA } \\
\text { methyltransferase } \\
3 \mathrm{~A} \\
\text { (Dnmt3a) }\end{array}$ & NM_153743 & $12 \mathrm{~A} 2-\mathrm{A} 3$ & $\begin{array}{c}\text { Adipose tissue, } \\
\text { bonemarrow, amygdale, } \\
\text { preoptic, cerebellum, } \\
\text { cerebral cortex, dorsal } \\
\text { striatum, hippocampus, } \\
\text { hypotalamus, main olfactory } \\
\text { epithelium, olfactory bulb, } \\
\text { spinal cord upper, spinal } \\
\text { cord lower, substantia } \\
\text { nigra, embryo day } 10.5, \\
\text { ovary, placenta, umbilical } \\
\text { cord, uterus, heart, } \\
\text { lymphnode, skeletal muscle, } \\
\text { vomeronasal organ, } \\
\text { pancreas, pituitary, snout } \\
\text { epidermis, spleen, thymus, } \\
\text { thyroid, retina. }\end{array}$ & $\begin{array}{l}\text { Required for genome } \\
\text { wide de novo } \\
\text { methylation and is } \\
\text { essential for } \\
\text { development. }\end{array}$ \\
\hline $\begin{array}{l}\text { Early growth } \\
\text { response } 1 \\
\text { (Egr1) }\end{array}$ & NM_007913 & 18 & $\begin{array}{c}\text { Adipose tissue, adrenal } \\
\text { gland, amygdale, frontal } \\
\text { cortex, preoptic, } \\
\text { cerebellum, cerebral cortex, } \\
\text { dorsal root ganglia, } \\
\text { hippocampus, hypotalamus, } \\
\text { olfactory bulb, spinal cord } \\
\text { lower, substancia nigra, } \\
\text { ovary, heart, small intestine, } \\
\text { B220+B-cells, CD4+Tcells, } \\
\text { CD8+Tcells, lung, } \\
\text { lymphnode, skeletal muscle, } \\
\text { tongue, pituitary, digits, } \\
\text { epidermis, snout epidermis, } \\
\text { stomach, thymus, trachea. }\end{array}$ & $\begin{array}{l}\text { Transcriptional } \\
\text { regulator. }\end{array}$ \\
\hline $\begin{array}{l}\text { Deoxyhypusine } \\
\text { synthase } \\
\text { (Dhps) }\end{array}$ & NM_201408 & $8 \mathrm{C} 2$ & $\begin{array}{l}\text { Bonemarrow, amygdale, } \\
\text { frontal cortex, preoptic, } \\
\text { trigeminal, cerebellum, } \\
\text { cerebral cortex, dorsal root } \\
\text { ganglia, dorsal striatum, } \\
\text { hippocampus, hypotalamus, } \\
\text { olfactory bulb, } \\
\text { substantia nigra, } \\
\text { blastocysts, embryo day } \\
10.5 \text {, embryo day } 6.5 \text {, } \\
\text { embryo day } 7.5 \text {, embryo day } \\
8.5 \text {, embryo day } 9.5, \\
\text { mammary gland, uterus, } \\
\text { B220+B-cells, CD4+Tcells, } \\
\text { CD8+Tcells, lymphnode, } \\
\text { vomeronasal organ, thymus, } \\
\text { kidney, retina. }\end{array}$ & $\begin{array}{l}\text { Catalyzes the NAD- } \\
\text { dependent oxidative } \\
\text { cleavage of spermidine. }\end{array}$ \\
\hline $\begin{array}{l}\text { Insulin degrading } \\
\text { enzyme } \\
\text { (Ide) }\end{array}$ & NM_031156 & 19 & $\begin{array}{l}\text { Adipose tissue, adrenal } \\
\text { gland, main olfactory, } \\
\text { embryo day } 6.5 \text {, embryo day } \\
7.5, \text { embryo day } 9.5, \\
\text { fertilized egg, ovary, } \\
\text { prostate, uterus, oocyte, } \\
\text { heart, CD8+Tcells, , skeletal } \\
\text { muscle, vomeronasal organ, } \\
\text { salivary gland, tongue, } \\
\text { thymus, trachea, bladder. }\end{array}$ & $\begin{array}{c}\text { Can cleave insulin and } \\
\text { tgf-alpha. }\end{array}$ \\
\hline
\end{tabular}




\begin{tabular}{|c|c|c|c|c|}
\hline $\begin{array}{l}\text { Interleukin 12a } \\
\quad(\text { IL12a) }\end{array}$ & NM_008351 & 3 & $\begin{array}{c}\text { Brown fat, bone, } \\
\text { bonemarrow, preoptic, } \\
\text { cerebellum, cerebral cortex, } \\
\text { dorsal striatum, olfactory } \\
\text { bulb, spinal cord upper, } \\
\text { substantia nigra, embryo } \\
\text { day } 10.5 \text {, embryo day } 6.5 \text {, } \\
\text { embryo day } 7.5 \text {, embryo day } \\
8.5 \text {, embryo day 9.5, } \\
\text { fertilized egg, B220+B-cells, } \\
\text { CD8+Tcells, lymphnode, } \\
\text { skeletal muscle, spleen, } \\
\text { thyroid. } \\
\end{array}$ & $\begin{array}{l}\text { Cytokine that can act } \\
\text { as a growth factor for } \\
\text { activated T and NK } \\
\text { cells (by similarity). }\end{array}$ \\
\hline $\begin{array}{l}\text { Helicase, mus308- } \\
\text { like (Drosophila) } \\
\text { (Hel308) }\end{array}$ & BC082601 & $5 \mathrm{E}$ & Fertilized egg, oocyte. & $\begin{array}{l}\text { ATP binding, DNA } \\
\text { metabolism, helicase } \\
\text { activity, hydrolase } \\
\text { activity, RNA binding, } \\
\text { single-stranded DNA- } \\
\text { dependent ATP- } \\
\text { dependent DNA } \\
\text { helicase activity }\end{array}$ \\
\hline $\begin{array}{l}\text { Nuclear receptor } \\
\text { subfamily } 3 \text {, group } \\
\text { C, member } 1 \\
(\mathrm{Nr} 3 \mathrm{c} 1)\end{array}$ & NM_008173 & 18 & $\begin{array}{l}\text { Brown fat, Adipose tissue, } \\
\text { frontal cortex, preoptic, } \\
\text { cerebellum, main olfactory } \\
\text { epithelium, ovary, placenta, } \\
\text { umbilical cord, large } \\
\text { intestine, B220+B-cells, } \\
\text { CD4+Tcells, CD8+Tcells, } \\
\text { lung, skeletal muscle, } \\
\text { epidermis, thymus } \\
\text { trachea, kidney. }\end{array}$ & $\begin{array}{c}\text { Receptor for } \\
\text { glucocorticoids (gc). }\end{array}$ \\
\hline
\end{tabular}




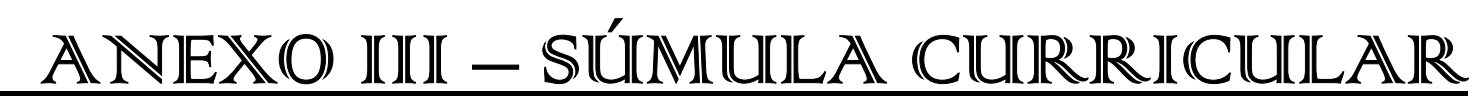




\section{CURRICULUM VITAE (MAIO DE 2007)}

Danielle Aparecida Rosa de Magalhães

Bióloga

E-mail: danrosa@rge.fmrp.usp.br

\section{DADOS PESSOAIS:}

Nome: Danielle Aparecida Rosa de Magalhães

Endereço: Rua Padre Anchieta, 2273

Ribeirão Preto - SP CEP: 14051-220

Telefone: (16) 36333615/81129237

Filiação: Alfredo Manoel de Magalhães e Neide Maria Souza de Magalhães

Nacionalidade: Brasileira

Data e Local de Nascimento: 25/08/1978, Ribeirão Preto - SP, Brasil

Estado Civil: Solteira

\section{DADOS DE IDENTIFICAÇÃO:}

Carteira de identidade: 24439754-5, SSP/Ribeirão Preto/19-09-96

Cadastramento de Pessoa Física: 278116268-02

Título de Eleitor: 2557155701/91

\section{FUNÇÃO ATUAL:}

Doutorado: Departamento de Genética, Faculdade de Medicina de Ribeirão Preto - USP, Campus de Ribeirão Preto, com bolsa de auxílio à pesquisa da FAPESP, área de concentração: Imunogenética Molecular.

\section{ESCOLARIDADE:}

* Doutor em Ciências (em andamento) pela Faculdade de Medicina de Ribeirão Preto - USP. Área de concentração: Genética; Subárea: Imunogenética Molecular - Projeto de Tese: Análise do Transcriptoma Durante a Ontogenia do Timo. Data limite para defesa: 02/2008. 
* Bacharel em Ciências Biológicas pela Faculdade de Filosofia, Ciências e Letras de Ribeirão Preto - USP, cursado no período de 1999 a julho de 2003 - Diploma conferido em 08 de Agosto de 2003.

* Licenciada em Ciências Biológicas pela Faculdade de Filosofia, Ciências e Letras de Ribeirão Preto - USP, cursado no período de 1999 a 2002 - Diploma conferido em 20 de Dezembro de 2002.

\section{CURSOS DE EXTENSÃO UNIVERSITÁRIA}

$>$ Curso de Radioproteção para Manuseio de Fontes Radioativas não Seladas realizado no período de 27 de novembro a 08 de dezembro de 2006 na Faculdade de Medicina de Ribeirão Preto - USP cumprindo carga horária total de 40 horas.

> Course "Transcriptome Analysis: Theoretical Basis and Applications", realizado no período de 29 de novembro a 2 de dezembro de 2005 no Departamento de Genética da Faculdade de Medicina de Ribeirão Preto-USP e ministrado pela Dra. Catherine NGUYEN, Diretora de pesquisa - INSERM - ERM 206 TAGC - Marseille-França, cumprindo carga horária total de 16 horas.

> Curso “Utilizando a Técnica de RNA interference (RNAi) para silenciamento gênico" realizado durante o $49^{\circ}$ Congresso Nacional de Genética em Águas de Lindóia-SP, no período de 16 a 19 de setembro de 2003.

> Curso "Polimorfismos de genes associados ao sistema imune e sua relação com doenças" realizado durante o 48ํㅡㄹ Congresso Nacional de Genética em Águas de Lindóia-SP, no período de 17 a 20 de setembro de 2002.

$>$ Curso de Difusão Cultural intitulado "Mini Curso em Imunologia Básica e Aplicada" realizado pela Faculdade de Filosofia, Ciências e Letras de Ribeirão Preto em setembro de 2000.

$>$ Mini Curso intitulado "Técnicas em Imunobiologia" ministrado pelo Prof. Dr. Geraldo Thedei Júnior e pela Dra. Adriana Januário, realizado no período de 29 de setembro a $1^{0}$ de outubro de 1999 durante a XXVII Semana de Bio-Estudos da FFCLRP-USP 


\section{ESTÁGIOS}

Laboratório de "Imunogenética Molecular" do Departamento de Genética da Faculdade de Medicina de Ribeirão Preto - USP, sob a orientação do Prof. Dr. Geraldo Aleixo da Silva Passos, no período de fevereiro de 2001 a dezembro de 2002.

Laboratório de "Ecofisiologia de Roedores Silvestres" do Departamento de Biologia da Faculdade de Filosofia Ciências e Letras de Ribeirão Preto - USP, sob a orientação da Prof. Dra. Elisabeth Spinelli de Oliveira, no período de janeiro a julho de 2000.

\section{ESTÁGIO NO EXTERIOR}

$>$ Laboratório “INSERM ERM 206, (TAGC- Technologies Avancées pour le Génome et la Clinique)" localizado na cidade de Marseille, França e dirigido por Catherine Nguyen, com linha de pesquisa voltada para estudos de Transcriptoma, utilizando a tecnologia de Microarrays Humanos e Murinos.

\section{MONITORIAS E AULAS PRÁTICAS}

Aula Prática - "Noções práticas sobre a aplicação de cDNA-microarrays") durante o IX Curso de Verão de Genética, realizado pelo Departamento de Genética da FMRP-USP para alunos de graduação, durante o período de 26 de janeiro a 06 de fevereiro de 2004.

> Monitora voluntária junto à disciplina de "Biologia Celular" do Departamento de Biologia da FFCLRP-USP durante o $1^{\circ}$ semestre de 2000. 


\section{PALESTRAS PROFERIDAS}

$>$ Aula teórico-prática sobre "Microarrays" no Laboratório de Imunogenética Molecular durante o XII Curso de Verão em Genética da Faculdade de Medicina de Ribeirão Preto - USP, realizado pelo Departamento de Genética para alunos de graduação, no período de 22 de janeiro a 02 de fevereiro de 2007.

> Palestra intitulada "Assinaturas de Hibridação durante a Ontogenia do Timo" durante o X Curso de Verão em Genética, realizado pelo Departamento de Genética para alunos de graduação, durante o período de 17 a 28 de janeiro de 2005.

$>$ Aula Teórica intitulada "Modulação de genes codificadores de proteínas de sinalização de células T durante o desenvolvimento de Timo" ministrada no dia 26 de outubro 2004, como parte da Disciplina RIM-5728 (Genômica Aplicada à Imunologia) oferecida aos alunos de Mestrado e Doutorado do Programa de Pós-Graduação em Imunologia Básica e Aplicada da FMRP-USP e coordenada pelo Prof. Dr. Geraldo A.S. Passos.

\section{EXPERIÊNCIA DIDÁTICA}

Estágio de Licenciatura com carga horária de 210 horas distribuídos em colégio de Ensino Fundamental e Médio, localizados na cidade de Ribeirão Preto, São Paulo, com aplicações práticas das teorias do Curso de Graduação “Práticas de Ensino em Biologia I e II" e "Didática Geral I e II".

\section{PRODUÇÃO CIENTÍFICA}

\section{A) TRABALHOS PUBLICADOS EM PERIÓDICOS (COMPLETOS)}

1) MAGAlHÃeS, D. A.; SILVEIRA, Eduardo Lani V; JUNTA, Cristina M.; GARCIA, Paula Sandrin; FACHIN, Ana Lúcia; DONADI, Eduardo A.; SAKAMOTO-HOJO, Elza T.; PASSOS, 
Geraldo A. S. Promiscuous Gene Expression in the Thymus: The Root of Central Tolerance. Clinical and Developmental Immunology, v. 13 p. 81-100, 2006.

2) CARDOSO, Renato S.; MAGAlHÃES, D. A.; BAIÃO, Ana Maria T.; JUNTA, Cristina M.; MACEDO, Claudia; MARQUES, Márcia M. C.; SAKAMOTO-HOJO, Elza T.; DONADI, Eduardo A.; PASSOS, Geraldo A. S. Onset of Promiscuous gene expression in murine fetal thymus organ culture. Immunology. Londres, v. 119(3), p. 369-375, 2006.

3) CARDOSO, Renato S.; JUNTA, Cristina M.; MACEDO, Claudia; MAGAlHÃES, D. A.; MELLO, Stephano S.; NGUYEN, C.; HOULGATTE, R.; DONADI, Eduardo A.; SAKAMOTOHOJO, Elza T.; PASSOS, Geraldo A. S. Hybridization signatures of gama-irradiated murine fetal thymus organ culture (FTOC) reveal modulation of genes associated with T-cell receptor V(D)J recombination and DNA repair. Molecular Immunology, Inglaterra, v. 43, p. 464-472, 2006.

4) MAGAlHÃES, D. A.; MACEDO, Claudia; JUNTA, Cristina M.; MELLO, Stephano S.; MARQUES, Márcia M. C.; CARDOSO, Renato S.; SAKAMOTO-HOJO, Elza T.; DONADI, Eduardo A.; PASSOS, Geraldo A. S. Hybridization Signatures During Thymus Ontogeny Reveals Modulation of Genes Coding for T-Cell Signaling Proteins. Molecular Immunology, Inglaterra, v. 42, p. 1043-1048, 2005.

\section{B) TRABALHOS PUBLICADOS EM ANAIS (RESUMOS)}

1) MAgalhães, D. A.; MACEDO, Claudia; JOLY; Joly F; PUTHIER, D.; LORIOD, B.; BOULANGER, N.; VICTORERO, G.; NGUYEN, C.; PASSOS, Geraldo A. S. Identification of Specific T-Cell Gene Expression Profiles During the Fetal Thymus Maturation.. In: 52 Congresso Brasileiro de Genética, 2006, Foz do Iguaçu-PR.

2) MAGAlHÃES, D. A.; JUNTA, Cristina M.; MACEDO, Claudia; GARCIA, Paula Sandrin; FACHIN, Ana Lúcia; MELLO, Stephano S.; SAKAMOTO-HOJO, Elza T.; DONADI, Eduardo A.; PASSOS, Geraldo A. S. Identification Of Genes Preferentially Expressed By The Thymus During Ontogeny. In: 51ํㅡㄹ Congresso Brasileiro de Genética, 2005, Água de Lindóia-SP. 
3) LOBO, C. H.; MAGALHÃES, D. A.; FRANCOY, T. M.; MACEDO, Claudia; BRASSESCO, M.

S.. Presença de NORs em uma linhagem celular de Apis mellifera testada por FISH e AgNO3. In: 51 Congresso Brasileiro de Genética, 2005, Água de Lindóia-SP.

4) MAGAlHÃES, D. A.; JUNTA, Cristina M.; MACEDO, Claudia; GARCIA, Paula Sandrin; MELLO, Stephano S.; FACHIN, Ana Lúcia; SILVEIRA, Eduardo Lani V; PAULA, Marina Oliveira e; BLADÉS, Carlos Rodrigo Zárate ; SAKAMOTO-HOJO, Elza T. ; DONADI, Eduardo A. ; PASSOS, Geraldo A. S. . cDNA Microarrays May Potentially Identify New Candidates Genes That Modulate the In Vivo T Cell Maturation. In: XXIX Meeting of Brazilian Society of Immunology, 2004, Ouro Preto -MG.

5) PAULA, Marina Oliveira e ; BLADÉS, Carlos Rodrigo Zárate ; SILVEIRA, Eduardo Lani V ; FACHIN, Ana Lúcia ; JUNTA, Cristina M. ; MELlO, Stephano S. ; MAGALHÃES, D. A. ; MACEDO, Claudia ; GARCIA, Paula Sandrin ; SILVA, Célio Lopes ; DONADI, Eduardo A. ; SAKAMOTO-HOJO, Elza T. ; PASSOS, Geraldo A. S. . Interleukin 7 modulates the gene expression in murine adult thymus organ culture. In: XXIX Meeting of Brazilian Society of Immunology, 2004, Ouro Preto -MG.

6) MAgAlHÃES, D. A.; JUNTA, Cristina M.; MACEDO, Claudia; MELlO, Stephano S.; MARQUES, Márcia M. C.; CARDOSO, Renato S.; SAKAMOTO-HOJO, Elza T.; DONADI, Eduardo A.; PASSOS, Geraldo A. S. USO DE cDNA Microarrays Na Identificação de Novos Genes Candidatos À Modulação Da Recombinação V(D)J Dos Receptores De Células T (TCR).. In: 49ํㅡㄹ Congresso Nacional de Genética, 2003, Águas de Lindóia-SP.

7) MAGAlHÃeS, D. A.; MACEDO, Claudia; JUNTA, Cristina M.; MELLO, Stephano S.; MARQUES, Márcia M. C.; CARDOSO, Renato S.; SAKAMOTO-HOJO, Elza T.; DONADI, Eduardo A.; PASSOS, Geraldo A. S.. Association of T-cell Receptor Beta (TRBV8.1-DB2.1) Rearrangement with Hybridization Signatures During Thymus Ontogeny. In: 6th International Meeting of the Microarray Gene Expression Data Society (MGED), 2003, Aix en ProvenceFrance, 2003.

8) MAGAlHÃES, D. A.; MACEDO, Claudia; JUNTA, Cristina M.; PASSOS, Geraldo A. S.. Detecção do início da recombinação $\mathrm{V}(\mathrm{D}) \mathrm{J}$ durante a ontogenia do timo de heterozigotos entre 
linhagens isogênicas de camundongos.. In: 48ํㅡㄹ Congresso Nacional de Genética, 2002, Águas de Lindóia-SP.

9) MAGAlHÃeS, D. A.; MACEDO, Claudia; JUNTA, Cristina M.; PASSOS, Geraldo A. S.. Emergência da recombinação V(D)J de TCRV 8.1 e análise da expressão gênica no timo de heterozigotos entre linhagem isogênica de camundongos.. In: 13º Encontro de Biólogos CRBio1, 2002, São Pedro-SP.

10) MAGAlHÃES, D. A.; JUNTA, Cristina M.; MACEDO, Claudia; PASSOS, Geraldo A. S.. Detecção do início da recombinação V(D)J no locus TCR beta e análise da expressão gênica do timo de heterozigotos entre linhagens isogênicas de camundongos. In: 10 o Simpósio Internacional de Iniciação Científica da Universidade de São Paulo, 2002, Ribeirão Preto-SP.

\section{C) TRABALHOS APRESENTADOS EM CONGRESSOS E/OU REUNIÕES CIENTÍFICAS NO BRASIL}

1) MAGAlHÃES, D. A.; MACEDO, Claudia; JOLY,; Joly F; PUTHIER, D.; LORIOD, B.; BOULANGER, N.; VICTORERO, G.; NGUYEN, C.; PASSOS, Geraldo A. S. Identification of Specific T-Cell Gene Expression Profiles During the Fetal Thymus Maturation.. In: 52 ${ }^{\circ}$ Congresso Brasileiro de Genética, 2006, Foz do Iguaçu-PR.

2) MAgAlhãeS, D. A.; JUNTA, Cristina M.; MACEDO, Claudia; GARCIA, Paula Sandrin; FACHIN, Ana Lúcia; MELLO, Stephano S.; SAKAMOTO-HOJO, Elza T.; DONADI, Eduardo A.; PASSOS, Geraldo A. S. Identification Of Genes Preferentially Expressed By The Thymus During Ontogeny. In: 51ํㅡㄹ Congresso Brasileiro de Genética, 2005, Água de Lindóia-SP.

3) MAgAlHÃES, D. A.; JUNTA, Cristina M.; MACEDO, Claudia; GARCIA, Paula Sandrin; MELLO, Stephano S.; FACHIN, Ana Lúcia; SILVEIRA, Eduardo Lani V; PAULA, Marina Oliveira e; BLADÉS, Carlos Rodrigo Zárate ; SAKAMOTO-HOJO, Elza T. ; DONADI, Eduardo A. ; PASSOS, Geraldo A. S. . cDNA Microarrays May Potentially Identify New Candidates Genes That Modulate the In Vivo T Cell Maturation. In: XXIX Meeting of Brazilian Society of Immunology, 2004, Ouro Preto -MG. 
4) MAgAlhãeS, D. A.; JUNTA, Cristina M.; MACEDO, Claudia; MELLO, Stephano S.; MARQUES, Márcia M. C.; CARDOSO, Renato S.; SAKAMOTO-HOJO, Elza T.; DONADI, Eduardo A.; PASSOS, Geraldo A. S. USO DE cDNA Microarrays Na Identificação de Novos Genes Candidatos À Modulação Da Recombinação V(D)J Dos Receptores De Células T (TCR).. In: 49ํㅡㄹ Congresso Nacional de Genética, 2003, Águas de Lindóia-SP.

5) MAGAlHÃES, D. A.; MACEDO, Claudia; JUNTA, Cristina M.; PASSOS, Geraldo A. S.. Detecção do início da recombinação $\mathrm{V}(\mathrm{D}) \mathrm{J}$ durante a ontogenia do timo de heterozigotos entre linhagens isogênicas de camundongos.. In: 48oㅡ Congresso Nacional de Genética, 2002, Águas de Lindóia-SP.

6) MAGAlHÃES, D. A.; MACEDO, Claudia; JUNTA, Cristina M.; PASSOS, Geraldo A. S.. Emergência da recombinação $V(D) J$ de TCRV 8.1 e análise da expressão gênica no timo de heterozigotos entre linhagem isogênica de camundongos.. In: 13o Encontro de Biólogos CRBio1, 2002, São Pedro-SP.

7) MAGAlHÃES, D. A.; JUNTA, Cristina M.; MACEDO, Claudia; PASSOS, Geraldo A. S.. Detecção do início da recombinação V(D)J no locus TCR beta e análise da expressão gênica do timo de heterozigotos entre linhagens isogênicas de camundongos. In: 10º Simpósio Internacional de Iniciação Científica da Universidade de São Paulo, 2002, Ribeirão Preto-SP.

\section{D) TRABALHOS APRESENTADOS EM CONGRESSOS E/OU REUNIÕES CIENTÍFICAS NO EXTERIOR}

1) MAgAlhãeS, D. A.; MACEDO, Claudia; JUNTA, Cristina M.; MELLO, Stephano S.; MARQUES, Márcia M. C.; CARDOSO, Renato S.; SAKAMOTO-HOJO, Elza T.; DONADI, Eduardo A.; PASSOS, Geraldo A. S. Association of T-cell Receptor Beta (TRBV8.1-DB2.1) Rearrangement with Hybridization Signatures During Thymus Ontogeny. In: 6th International Meeting of the Microarray Gene Expression Data Society (MGED), 2003, Aix en Provence- France, 2003. 


\section{TRABALHO TÉCNICO}

Relatório de Análise de Segurança para Laboratórios de Pesquisa com a finalidade de Renovação de Licença para uso de Fontes Radioativas não Seladas no Laboratório de Imunogenética Molecular da Faculdade de Medicina de Ribeirão Preto - SP/USP, Departamento de Genética. Duração de 40 horas.

\section{PRÊMIOS E TÍTULOS}

* 1o Premio de Apresentação de Trabalhos concedido pela Comissão de Avaliação de Painéis do Conselho Regional de Biologia -1ª região, com o trabalho intitulado “Emergência da recombinação V(D)J de TCRVB8.1 e Análise da Expressão Gênica no Timo de Heterozigotos entre Linhagens Isogênicas de Camundongos" apresentado durante o 13ํㅡㄹ Encontro de Biólogos do CRBio-1 realizado em São Pedro-SP de 25 a 28 de março de 2002.

\section{RELATOR DE TRABALHOS}

Atuação como Avaliadora na área Ciências Biológicas, subárea de Genética, no $14^{\mathrm{o}}$ SICUSP - Simpósio de Iniciação Científica da Universidade de São Paulo realizado pela Comissão de Pesquisa da FFCLRP-USP no Centro de Convenções de Ribeirão Preto durante o período de 13 de novembro de 2006.

Atuação como Avaliadora na área Ciências Biológicas, subárea de Genética, no 12º SICUSP - Simpósio de Iniciação Científica da Universidade de São Paulo realizado pela Comissão de Pesquisa da FFCLRP-USP no Centro de Convenções de Ribeirão Preto durante o período de 23 de dezembro de 2004. 


\section{PARTICIPAÇÃO EM CONGRESSOS E REUNIÕES CIENTÍFICAS NO BRASIL}

1) $52^{\circ}$ Congresso Brasileiro de Genética, realizado em Foz do Iguaçu - PR no período de 03 a 06 de setembro de 2006 .

2) $51^{\circ}$ Congresso Brasileiro de Genética, realizado em Águas de Lindóia-SP no período de 07 a 10 de setembro de 2005.

5) $49^{\circ}$ Congresso Nacional de Genética, realizado em Águas de Lindóia-SP no período de 16 a 19 de setembro de 2003.

6) $48^{\circ}$ Congresso Nacional de Genética, realizado em Águas de Lindóia-SP no período de 17 a 20 de setembro de 2002.

7) $10^{\circ}$ Simpósio Internacional de Iniciação Científica da Universidade de São Paulo, realizado em Ribeirão Preto-SP no dia 05. 2002.

8) 13o Encontro de Biólogos do CRBio -1, realizado em São Pedro-SP no período de 25 a 28 de março de 2002.

9) XVIII Encontro Anual de Etologia, realizado em Florianópolis-SC no período de 14 a 17 de outubro de 2000.

\section{BOLSA DE AUXÍLIO À PESQUISA}

- Bolsa de Iniciação Científica concedida pela Fundação de Amparo à Pesquisa do Estado de São Paulo (FAPESP) para o desenvolvimento do projeto de Conclusão do Curso de Bacharel em Ciências Biológicas (Monografia) intitulado “Análise do início da recombinação $\mathrm{V}(\mathrm{D}) \mathrm{J}$ do receptor de células $\mathrm{T}$ beta ( TRBV8.1 - BD2.1) e da expressão gênica durante a ontogenia do timo de linhagens isogênicas de camundongos heterozigotos", sob a orientação do Prof. Dr. Geraldo A.S. Passos.

- Bolsa de Doutorado Direto concedida pela Fundação de Amparo à Pesquisa do Estado de São Paulo (FAPESP) na área de Imunogenética Molecular, para o desenvolvimento do projeto de Tese intitulado "Análise do Transcriptoma Durante a Ontogenia do Timo", sob a orientação do Prof. Dr. Geraldo A. S. Passos.

- Bolsa de Estágio de Doutorado - PDEE (Bolsa Sanduíche) concedida pela Fundação Coordenação de Aperfeiçoamento de Pessoal de Nível Superior 
(CAPES) na área de Imunogenética Molecular, para o desenvolvimento de parte do projeto de Tese intitulado "Análise do Transcriptoma Durante a Ontogenia do Timo", sob a orientação do Prof. Dr. Geraldo A. S. Passos, no Brasil, e surpervisão da Dra. Catherine Nguyen, diretora da unidade INSERM ERM 206, Marseille - França, durante o período de 08 de fevereiro a 04 de agosto de 2006.

\section{IDIOMAS}

$\checkmark$ Certificado de Proficiência em Francês "Test de Français" aplicado pela “Délègation Générale de L'alliance Française au Brésil” com nível bom no francês oral e escrito, realizado no dia 19 de Agosto de 2005.

$\checkmark$ Certificado de exame TEAP “Test of English for Academic Purposes” na área de Saúde/Biológicas realizado em Ribeirão Preto-SP no dia 13 de Setembro de 2002. 
$A \mathbb{N} E X(O)][\mathbb{V}$

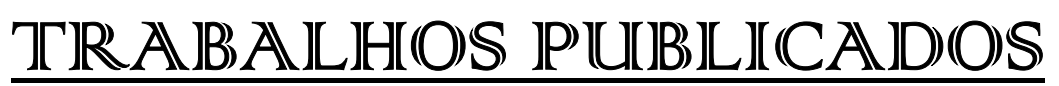




\title{
Hybridization signatures during thymus ontogeny reveals modulation of genes coding for T-cell signaling proteins
}

\author{
Danielle A.R. Magalhães ${ }^{\mathrm{a}}$, Claudia Macedo ${ }^{\mathrm{a}}$, Cristina M. Junta ${ }^{\mathrm{a}}$, Stephano S. Mello ${ }^{\mathrm{b}}$, \\ Márcia M.C. Marques ${ }^{\mathrm{a}}$, Renato S. Cardoso ${ }^{\mathrm{a}}$, Elza T. Sakamoto-Hojo ${ }^{\mathrm{b}}$, \\ Eduardo A. Donadi ${ }^{\mathrm{c}}$, Geraldo A.S. Passos ${ }^{\mathrm{a}, \mathrm{d}, *}$ \\ ${ }^{a}$ Molecular Immunogenetics Group, Department of Genetics, Faculty of Medicine, University of São Paulo (USP), 14040-900 Ribeirão Preto, SP, Brazil \\ ${ }^{\mathrm{b}}$ Laboratory of Cytogenetics and Mutagenesis, Department of Genetics, Faculty of Medicine, USP, 14040-900 Ribeirão Preto, SP, Brazil \\ ${ }^{\mathrm{c}}$ Department of Medicine, Faculty of Medicine, USP, 14040-900 Ribeirão Preto, SP, Brazil \\ d Discipline of Genetics (DMEF), Faculty of Dentistry, USP, 14040-900 Ribeirão Preto, SP, Brazil
}

Received 18 August 2004; accepted 29 September 2004

Available online 23 November 2004

\begin{abstract}
Non-manipulated inbred mouse strains constitutes an interesting model-system for in vivo studies on thymus ontogeny due to the possibility to observe the molecular events of the thymocyte maturation. In previous studies, using RT-PCR method, we have found that several immune system genes such as interleukins and MHC are differentially expressed during ontogeny of the thymus whose genes act as modulators of T-cell differentiation. To determine which other genes are modulated on a large-scale basis, we measured the levels of mRNA expression in mouse fetal thymus (14-17 days of gestation) by hybridization with cDNA microarrays containing 1,576 cDNA sequences derived from the IMAGE MTB library. T-cell maturation was monitored by detection of the T-cell receptor beta TRBV8.1-BD2.1 rearranged DNA segment. Each developmental phase of thymus, displayed a characteristic expression profile, as evaluated by the Cluster and Tree-View softwares. Genes differentially and significantly expressed were selected on the basis of significance analysis of the microarray data (SAM program). With the reclustering of only significantly expressed genes, it was possible to characterize the phases of thymus ontogeny, based on the differential profile of expression. Our method provided the detection of genes implicated in the cell signaling, such as the hematopoietic cell signal transducer gene, genes implicated in T-cell calcium influx (tyrosine phosphatase) and calcium signaling proteins (vesicle transport binding protein 3, proline rich Gla, casein kinase alpha 1 and Down syndrome homolog protein 1) and a gene important for the protein transport, including T-cell receptors chains, towards the cell membrane (Golgi SNAP receptor complex member 2). The results demonstrate that the cDNA microarray used to explore the gene expression was useful for understanding the modulation of several cell-signaling genes, including the calcium cascade pathway, which is important for individual stages of T-cell maturation and control of anergy during thymus ontogeny. (c) 2004 Elsevier Ltd. All rights reserved.
\end{abstract}

Keywords: Thymus ontogeny; T-cell signaling; cDNA microarrays; Gene expression profiling; Cluster analysis

\section{Introduction}

The differentiation of thymocytes to mature T-cells occurs within the fetal thymus and all developmental stages are distinguishable by their expression of combination of CD cellsurface markers. This is a highly modulated phenomenon,

\footnotetext{
* Corresponding author. Tel.: +55 16602 3030; fax: +55 166330069

E-mail address: passos@ rge.fmrp.usp.br (G.A.S. Passos).
}

whose central molecular machinery is formed by the recombinase complex (RAG-1 and RAG-2) directly implicated in the $\mathrm{V}(\mathrm{D}) \mathrm{J}$ recombination of T-cell receptor gene segments (TRA, TRB, TRG and TRD) (Lefranc and Lefranc, 2001). The occurrence of the $\mathrm{V}(\mathrm{D}) \mathrm{J}$ reaction is important for triggering the maturation of T-cells and is also regulated by several other gene products such as interleukins (Fink and McMahan, 2000; Fugmann, 2002; Muegge et al., 1993; Sollof et al., 1997). 
The timing of T-cell maturation during thymus ontogeny is different among inbred mouse strains, strongly suggesting a role for the genetic background in the modulation of this phenomenon (Junta and Passos, 1998; Macedo et al., 1999).

Using the reverse-transcription-PCR (RT-PCR) method we have previously found that several immune system-related genes such as interleukins and the major histocompatibility complex (MHC) are differentially expressed during thymus ontogeny of inbred mouse strains (Espanhol et al., 2003).

Although the knockout mice have been used as a valuable tool for defining the role of a set of immune system-related genes (Mak et al., 2001), non-manipulated mouse strains still constitute a classical model-system useful for studies on the in vivo modulation of several other genes acting in cascade during thymocyte development.

The new functional genomic technology using the cDNA microarray method provides the opportunity to perform a comparative analysis between the different phases of the thymus ontogeny, yielding quantitative expression data of hundreds or thousands of genes in a single experiment.

The early fetal thymus has homogeneous cell populations composed of double negative (DN) thymocytes, whose proportion changes to double positive (DP) in the late stages of fetal development. In contrast, the newborn and adult thymus is the place of arrival of new colonizing precursors, which contribute to the formation of heterogeneous cell populations including macrophages and dendritic cells (Shortman and $\mathrm{Wu}, 1996)$.

In this study, we evaluated the dynamic transcriptional profile of thymus development observed during the gestational period of (Balb-c $\times$ C57Bl/6) $F_{1}$ hybrid mice using a set of two nylon cDNA microarrays containing a total of 1,576 thymus IMAGE sequences. Each phase of thymus development exhibited a characteristic gene expression pattern involving genes of known functions, permiting the identification of those implicated in the T-cell signaling pathway and expressed sequence tags (ESTs) whose functions are still unknown. The differentially and significantly expressed genes and ESTs observed here may be considered as novel markers characterizing individual stages of thymus ontogeny.

\section{Material and methods}

\subsection{Fetal thymus, RNA and DNA preparation}

The (Balb-c $\times \mathrm{C} 57 \mathrm{Bl} / 6) \mathrm{F}_{1}$ hybrid mice were obtained in our own animal facilities. Pregnant Balb-c females were sacrificed by ether inhalation and the fetuses were surgically collected from the uterus. The age of the fetus (in days post coitum, p.c.) was confirmed on the basis of the morphological characteristics of each development phase (Rugh, 1968).

Fetal thymus tissue (1 mg containing approximately $1 \times 10^{7}$ cells) was obtained by surgery under a stereomicroscope and immediately processed for total RNA and genomic
DNA extractions using Trizol ${ }^{\circledR}$ reagent, following the manufacturer's instructions (Invitrogen).

\subsection{TRBV8.1-BD2.1 recombination assay}

T-cell maturation was monitored by detection of rearrangements between segments TRBV8.1-BD2.1 during thymus development using PCR (Muegge et al., 1993). The oligonucleotide primers were the VB8.1 forward primer (primer 1, GAGGCTGCAGTCACCCAAAGTCCAA) the VB8.1 reverse primer (primer 2, ACAGAAATATACAGCTGTCTGAGAA), and the JB2.1 reverse primer (primer 3, TGAGTCGTGTTCCTGGTCCGAAGAA). The PCR reaction mixture contained $35 \mathrm{mM}$ Tris $(\mathrm{pH} 8.3), 50 \mathrm{mM} \mathrm{KCl}$, $2.5 \mathrm{mM} \mathrm{MgCl}_{2}$, bovine serum albumin $(100 \mu \mathrm{g} / \mathrm{ml})$, nucleotide triphosphates (NTPs) $(2 \mu \mathrm{M}$ each), the primers ( $0.5 \mu \mathrm{M}$ each), $1 \mathrm{U}$ Taq polymerase (Amersham Biosciences, Buckinghamshire, England), with a constant amount of genomic DNA $(1 \mu \mathrm{g})$ from each developmental stage. The PCR program consisted of 30 cycles $\left(1 \mathrm{~min}\right.$ at $94^{\circ} \mathrm{C}, 2.5 \mathrm{~min}$ at $54{ }^{\circ} \mathrm{C}$, and $1.5 \mathrm{~min}$ at $70^{\circ} \mathrm{C}$, with a 7 -min extension period).

The PCR product obtained with primers 1 and 3 was resolved on 1.2\% agarose gel and blotted on Hybond Nylon + (Amersham Biosciences). The rearranged VB8.1DB2.1 330 bp segment was detected by Southern hybridization with the ${ }^{32} \mathrm{P}$-labeled PCR product of $100 \mathrm{bp}$ obtained with primers 1 and 2, and visualized using a phosphor imager system (Cyclone, Packard Co. USA).

\section{3. cDNA-microarray method}

We used a pair of cDNA microarrays containing a total of 1,576 clones in the form of PCR products, spotted in duplicate on $2.5 \times 7.5 \mathrm{~cm}$ Hybond $\mathrm{N}+$ nylon membranes (Amersham Biosciences). The arrays were prepared in our laboratory using a Generation III Array Spotter (AmershamMolecular Dynamics). A complete file providing all genes present in the microarrays used in this study is available on line at http://rge.fmrp.usp.br/passos/nylon_array/mtb1.

Mouse EST cDNA clones were obtained from the Soares thymus 2NbMT normalized library, prepared from a C57B1/6J 4-week-old male thymus, and available in the I.M.A.G.E. Consortium (http://image.llnl.gov/image/html/ iresources.shtml).

cDNA inserts were homogeneous in size (near $1 \mathrm{~Kb}$ ) and cloned in three vectors (pT7T3D, pBluescript and Lafmid) and were amplified in 384- or 96-well plates using vector-PCR amplification with the following primers, which recognize the three vectors, LBP $1 \mathrm{~S} 5^{\prime}$-GTGGAATTGTGAGCGGATACC- $3^{\prime}$ forward and LBP 1AS $5^{\prime}$ GCAAGGCGATTAAGTTGG- $3^{\prime}$ reverse.

The membranes were first hybridized with the LBP $1 \mathrm{AS}\left[\gamma_{-}{ }^{33} \mathrm{P}\right] \mathrm{dCTP}$ (Amersham Biosciences) labeled oligonucleotide (vector hybridization). Quantification of the obtained signals allowed the estimation of the amount of DNA 
deposited in each spot. After stripping, the membranes were subsequently used for hybridization with cDNA complex probes (sample hybridization).

The characterization of each cDNA sequence was updated using the Eloge ${ }^{\circledR}$ (Ipsogen, France, www.ipsogen. fr) software, which runs in our local server and links each clone ID with the genome data banks (GenBank, www.ncbi. nlm.ih.gov and S.O.U.R.C.E., http://genome-www5. stanford.edu/cgi-bin/source/sourceSearch), allowing a set of information such as sequence, biological and molecular functions, chromosomal location, percent identity with humans and expression in different tissues.

\subsection{Complex $c D N A$ probe preparation and hybridization}

In this study, we refer to the radioactive cDNA originated from the thymus RNA samples as complex probe and the PCR product originated from the clones and deposited on the nylon microarrays as target.

The ${ }^{33} \mathrm{P}$-labeled cDNA complex probes were prepared by reverse transcription of $10 \mu \mathrm{g}$ of thymus total RNA using oligo $\mathrm{dT}_{12-18}$ as primer. One hundred microliters of ${ }^{33} \mathrm{P}-$ cDNA complex probe containing 30-50 million cpm was hybridized with nylon microarrays as previously described (Bertucci et al., 2002; Nguyen et al., 1995; Verdeil et al., 2002).

\subsection{Imaging acquisition}

We used imaging plates and a phosphor imager (Cyclone, Packard Instruments, USA) to capture the hybridization signals and the Array Vision ${ }^{\circledR}$ (Imaging Research Inc. USA) to quantify the signals with local background subtraction, whose spots were matched with a template grid.

The ratio between vector probe hybridization values and complex probe hybridization values for each spot was used as reference normalization value. We employed also total intensity normalization, using the median expression value (Quackenbush, 2002).

\section{6. cDNA-microarray data analysis}

The gene expression data analyzed here were obtained from three independent determinations for each day of fetal development.

We used the SAM method (Significance Analysis of Microarrays available at http://www-stat.stanford. edu/ tibs/SAM/index.html) Tusher et al. (2001) to analyze the significant variations in the gene expression. This method is based on $t$-test statistics, specially modified to high throughput analysis. The significant variations in the gene expression of the developing thymus were compared with the 14 days p.c. (14 versus 15,14 versus 16 and 14 versus 17 days of gestation). The program calculates a global error chance, the false discovery rate (FDR) and a gene error chance ( $q$-value).

\subsection{Hierarchical clustering}

We used a hierarchical clustering algorithm, comparing means of different genes whose standard deviation did not overlap, whose objective was to compute a dendrogram that assembles all elements into a single tree. The software for this algorithm can be obtained from the author (http://rana.stanford.edu/clustering) (Eisen et al., 1998). Before clustering, the gene expression values were median-centered and converted to log. We used the Pearson correlation distance metrics and average linkage for clustering organization.

From the 1,576 sequences present on the microarrays, 315 (20\%) were excluded from the calculations by the software due to their low statistical significance (in this case were analyzed 1,261 sequences, including 200 named genes and 1,061 ESTs).

In order to cluster only genes whose expression values were significant, we used the values for the induced and repressed genes detected by the SAM method.

\section{Results}

\subsection{Monitoring thymocyte maturation}

The detection of the T-cell receptor TRBV8.1-BD2.1 rearranged DNA segment served as an indication of thymocyte maturation during the fetal development of the thymus. We detected the onset of TRBV8.1 V(D)J recombination at 14 days gestation in the heterozygous (Balb-c $\times \mathrm{C} 57 \mathrm{~B} 1 / 6) \mathrm{F}_{1}$ fetuses whose amount of the rearranged DNA fragment increased during thymus ontogeny (Fig. 1).

\subsection{Hierarchical clustering of significant genes}

The hierarchical cluster analysis, computing all the 1,261 sequences and probes from thymi of fetuses of different

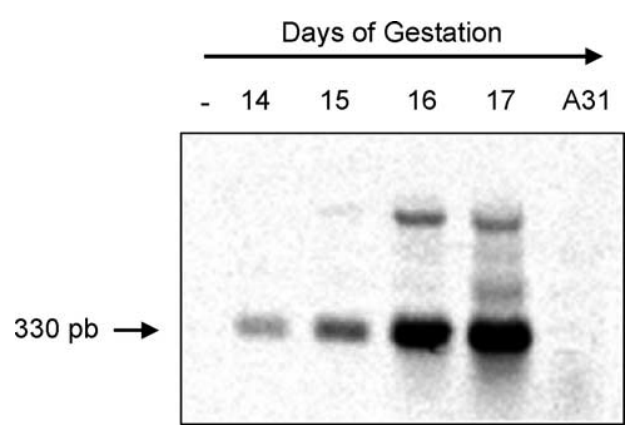

Fig. 1. Detection of the recombined TRBV8.1-BD2.1 segment in genomic DNA during thymus ontogeny of (Balb-c $\times \mathrm{C} 57 \mathrm{Bl} / 6) \mathrm{F}_{1}$ hybrid mice. $(-)=$ PCR without DNA, A31 $=$ murine $\mathrm{Balb} / 3 \mathrm{~T} 3$ derived fibroblast cell line DNA. 


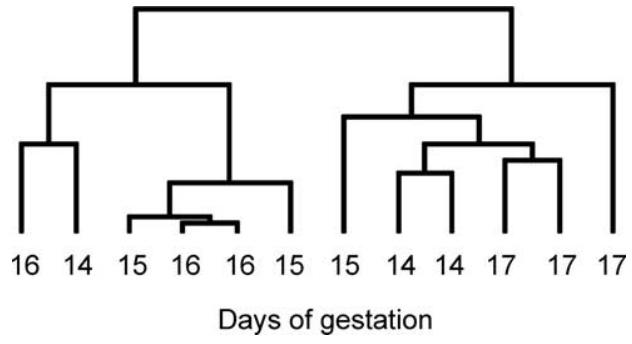

Fig. 2. Clustering samples of each day of thymus gestation of the (Balb$\mathrm{c} \times \mathrm{C} 57 \mathrm{~B} 1 / 6) \mathrm{F}_{1}$ hybrid mice considering the raw normalized expression data of the 1,261 genes. (www.rge.fmrp.usp.br/passos/TRBV81/cluster1261).

ages p.c., showed that there is variability in the patterns of gene expression of the thymus within mice for each day of gestation. This variability caused shuffling in the clustering of the RNA samples (cDNA probes) of fetuses (Fig. 2) (www.rge.fmrp.usp.br/passos/TRV81/cluster1261). We used the approach of clustering the significant genes proposed by the SAM program, i.e. only those induced or repressed genes whose variability was statistically significant. This approach successfully distinguished the samples of thymi according to days of gestation (Fig. 3) (www.rge.fmrp.usp.br/passos/TRBV81/reclustering/SAM).

\subsection{Genes differentially expressed in the developing thymus}

To identify significant changes in gene expression during fetal development of the thymus, we compared the stage when the onset of TRBV8.1 recombination occurs, at 14 days of gestation, with those observed on the subsequent days (14 versus 15,14 versus 16 and 14 versus 17 days p.c.). We used a scatter plot of the observed relative difference $d(i)$ versus the expected relative difference $d_{E}(i)$ as shown by the SAM program.

Most of the 1,261 genes tested presented $d(i) \cong d_{E}(i)$, i.e. their expression pattern did not change; however, some genes were significantly induced or repressed during thymus development (Table 1) (www.rge.fmrp.usp.br/passos/TRBV81/ SAM/table1).
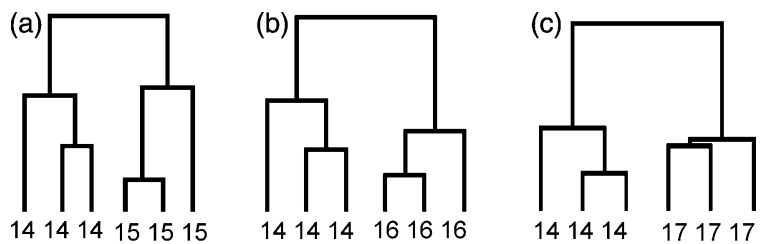

Days of gestation

Fig. 3. Reclustering samples of each day of thymus gestation of (Balb$\mathrm{c} \times \mathrm{C} 57 \mathrm{Bl} / 6) \quad \mathrm{F}_{1}$ hybrid mice considering only the significant expressed genes reported by the SAM program. (a) 14 vs. 15 , (b) 14 vs. 16 and (c) 14 vs. 17 days of gestation. (www.rge.fmrp.usp.br/passos/TRBV81/reclustering/ SAM).
Table 1

Number of genes differentially expressed during thymus development of $\left(\right.$ Balb-c $\times$ C57Bl/6) $F_{1}$ hybrid mice as reported by the SAM program ${ }^{\mathrm{a}}$

\begin{tabular}{llll}
\hline $\begin{array}{l}\text { Thymus development } \\
\text { (in days p.c.) }\end{array}$ & \multicolumn{2}{l}{ Significant genes } & FDR \\
\cline { 2 - 3 } & Induced & Repressed & \\
\hline $14-15$ & 31 & 73 & 48 \\
$14-16$ & 16 & 47 & 22 \\
$14-17$ & 18 & 21 & 64 \\
\hline
\end{tabular}

${ }^{a}$ Complete file of gene names available online (www.rge.fmrp.usp. br/passos/TRBV81/SAM/table1), FDR = false discovery rate (median).

\section{Discussion}

The aim of the present study was to perform a comparative large-scale gene expression analysis of thymocyte maturation during ontogeny of the thymus of (Balb-c $\times \mathrm{C} 57 \mathrm{Bl} / 6) \mathrm{F}_{1}$ hybrid mice to gain new insights into the modulation of gene transcriptions which could be correlated with T-cell maturation.

In previous observations, we described the different timing of T-cell maturation first by means of detection of the onset of the T-cell receptor TRA and TRB V(D)J recombinations in Balb-c, C57B1/6 and CBA/J strains (Junta and Passos, 1998; Macedo et al., 1999) and second by showing that several immune system-related genes such as interleukins and MHC displayed a differential expression pattern among these strains during thymus ontogeny (Espanhol et al., 2003).

T-cell differentiation and all developmental stages within the thymus are distinguishable by the expression of CD cellsurface marker combination. The $\mathrm{V}(\mathrm{D}) \mathrm{J}$ recombination of the TRA/TRB and TRG/TRD segments is a central phenomenon defining the T-cell fate, which is mediated by recombinase complex from $R A G-1$ and $R A G-2$ genes and modulated by several other gene products (Muegge et al., 1993; Sollof et al., 1997).

In the present study we showed that the emergence of the TRBV8.1 rearrangement during fetal development of the heterozygous (Balb-c $\times \mathrm{C} 57 \mathrm{~B} 1 / 6) \mathrm{F}_{1}$ mouse thymus occurs on day 14 p.c., similar to the parental strain C57Bl/6 (Espanhol et al., 2003). This suggest a participation of the genetic background of the C57Bl/6 strain in the control of T-cell maturation.

Despite the relevance of transgenic and knock-out mice to immunological research, the classical inbred nonmanipulated mouse strains constitute a model-system for studies on the effects of different genetic backgrounds on the modulation of T-cell maturation. In recent years, our group has pursued this approach with the classical inbred strains (Espanhol et al., 2003, 2004; Junta and Passos, 1998; Macedo et al., 1999) and in the present study we are reporting the first large-scale hybridization signatures of the thymus of heterozygous mice resulted from the fusion of two inbred different genetic backgrounds.

Two approaches were used to analyze the large-scale gene expression profile of the developing thymus of $F_{1}$ hybrid 
mice, encompassing a previous analysis of the genes which were only differentially expressed (Cluster and Tree-View method), and a second analysis clustering only those genes which were differentially and significantly expressed (SAM and Cluster and Tree-View methods).

By exploring a large set of genes, we intended to identify novel differentially expressed genes that could be used as markers for the individual stages of thymus ontogeny.

However, the clustering of raw expression data using the set of 1,261 genes caused a shuffling among RNA samples (cDNA probes) from each day of gestation (Fig. 2).

Considering the possibility that the similarity between samples from two distant days of gestation, such as 14 and 17 days p.c., as seen in the dendrogram of Fig. 2, might not be statistically significant, we applied a second round of clustering, now using the differentially and significantly expressed genes. Using this approach, it was possible to distinguish the days of gestation (Fig. 3), demonstrating the importance, in this study, of a previous statistical treatment instead of using only raw normalized microarray data to run the Cluster and Tree-View method.

Reclustering showed that the constitution of the gene cluster diverged for each stage of thymus development, i.e. each cluster harbored different genes with different expression patterns.

The 14th day p.c. RNA sample was considered to be the test sample for comparisons with the subsequent days of gestation (14 versus 15,14 versus 16 and 14 versus 17 days p.c.); however, in a given cluster, the repressed genes in a given day of gestation presented as induced on the following day. This is evidence that the genes used for data reclustering may play a role in thymus ontogeny and may represent novel candidate genes participating in the control of T-cell maturation.

It was possible to point out seven genes implicated in cell signaling. The hematopoietic cell signal transducer gene, Hcst, (accession number NM011827, ID 640698) was induced in the early stages of thymus development (14-16 days p.c.) and repressed at 17 days p.c. The Hcst protein is located outside the plasma membrane and is implicated in the coupling of receptor stimulation to downstream activation of GTPases. As the maturation of the thymocytes within the thymus depends on the participation of other cell types, such as stroma (Gill et al., 2003), this could represent evidence for a role of the Hcst gene in cellular communication via molecular signaling in the early thymus.

Genes implicated in the calcium signaling pathway were also modulated, such as the proline-rich Gla (Gcarboxyglutamic acid) polypeptide 2 gene, Prrg2, (accession number NM022999, ID 640686), the Down syndrome critical region homolog 1 gene, Dscrl, (accession number NM019466, ID 640638), and the syntaxin binding protein 3 gene, Stxbp3, (accession number NM011504, ID 640484), whose proteins have a role in the inhibition of the calcium influx pathway via calcineurin. These genes were repressed in the early ( 15 days p.c.) and late (17 days p.c.) thymus. The casein kinase 1,alpha 1 gene, Csnklal (accession number
Table 2

Number of ESTs differentially expressed during thymus development of $\left(\right.$ Balb-c $\times$ C57B1/6) $\mathrm{F}_{1}$ hybrid mice as reported by the SAM program ${ }^{\mathrm{a}}$

\begin{tabular}{llll}
\hline $\begin{array}{l}\text { Thymus development } \\
\text { (in days p.c.) }\end{array}$ & \multicolumn{2}{l}{ Significant ESTs } & FDR \\
\cline { 2 - 3 } & Induced & Repressed & \\
\hline $14-15$ & 20 & 49 & 48 \\
$14-16$ & 10 & 30 & 22 \\
$14-17$ & 10 & 14 & 64 \\
\hline
\end{tabular}

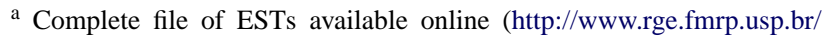
passos/TRBV81/SAM/table2), FDR = false discovery rate (median).

NM146087, ID 640022) whose protein is an inhibitor of calcineurin, was induced at 16 days p.c. These data, suggest that the calcium influx pathway could be activated in the thymus with 15 and 17 days p.c. and down-regulated with 16 days p.c.

All these genes above mentioned participates in the control of calcium influx pathway mediated by calcineurin, which is important in the activation of the nuclear factor of activated T-cells (NFAT), an transcription factor of T-cells.

As calcium signaling is implicated in the induction of Tcell anergy mediated through calcineurin and NFAT, our results could be useful to know the genes that induce tolerance (Feske et al., 2001, 2003; Heissmeyer et al., 2004).

The Golgi SNAP receptor complex member 2 gene, Gosr2, (accession number NM019650, ID 640152) was induced in the thymus from 15 to 17 days p.c. This gene has a role in the intracellular transport of newly synthesized proteins from the endoplasmic reticulum to their destination in the cell. Since we showed in this study that T-cells within the thymus begin to mature from 14 days p.c., the activation of the Gosr 2 gene in this phase is of particular importance due to the necessity of delivering the T-cell receptors chains on the cell surface.

Finally, we have shown that the protein tyrosine phosphatase 4a3 gene, Ptp4a3, (accession number NM008975, ID 640437), was induced in the thymus with 17 days p.c. There is evidence for a role of this gene in humans in colorectal cancer metastasis (Saha et al., 2001), i.e. cell migration. As the mature thymocytes should migrate from the thymus to blood stream, this may be evidence for the participation of the Ptp4a3 gene in the late stages of T-cell maturation including migration from the thymus.

The 133 EST sequences reclustered in the dendrograms of Fig. 3, whose functions were not yet assigned, presented a differential pattern of expression and were reclustered together with named genes (Table 2) (www.rge.fmrp.usp.br/passos/TRBV81/SAM/table2). This can be evidence for the participation of these ESTs in biological processes similar of those of the known genes. These ESTs are being studied by our group with the aim of associating their expression profile with gene function.

As the microarrays used in this study were prepared with thymus sequences, we explored their expression levels during the development of this organ. Although, the thymus harbors different cell types including macrophages and dendritic 
cells, we have found statistically significant expression of genes whose functions are associated with thymocytes.

The genes selected for discussion in this study may have a broader functions(s) during thymus development in cell types other than thymocytes. However, these aspects are still an open matter.

Taken together, our findings demonstrate that the cDNA microarrays and the bioinformatics programs employed here were useful tools to demonstrate the changes in the gene expression pattern of developing thymus which may reflect specific organ transcriptome programs.

\section{Acknowledgements}

This research was supported by the Brazilian agencies Fundação de Amparo à Pesquisa do Estado de São Paulo (Fapesp, 99/12135-9, 01/08278-0) and Conselho Nacional de Desenvolvimento Científico e Tecnológico (CNPq). We also would like to thank Drs. Catherine Nguyen and Remi Houlgatte and Mrs Beatrice Loriod and Geneviève Victorero from the Unité INSERM ERM 206, Marseille, France, for the help and discussions and for the IMAGE MTB cDNA mouse library clones used in this study.

\section{References}

Bertucci, F., Houlgatte, R., Granjeaud, S., et al., 2002. Prognosis of breast cancer and gene expression profiling using DNA arrays. Ann. N.Y. Acad. Sci. 975, 217-231.

Eisen, M., Spellman, P., Brown, P., Botstein, D., 1998. Cluster analysis and display of genome-wide expression patterns. Proc. Natl. Acad. Sci. U.S.A 95, 14863-14868.

Espanhol, A.R., Macedo, C., Junta, C.M., et al., 2003. Gene expression profiling during thymus ontogeny and its association with TRVB8DB2.1 rearrangements of inbred mouse strains. Mol. Cell Biochem. 252, 223-228.

Espanhol, A.R., Cardoso, R.S., Junta, C.M., et al., 2004. Large scale gene expression analysis of $\mathrm{CBA} / \mathrm{J}$ mouse strain fetal thymus using cDNA-array hybridizations. Mol. Cell. Biochem. 206, 65-68.
Feske, S., Giltnane, J., Dolmestsch, R., et al., 2001. Gene regulation mediated by calcium signals in $\mathrm{T}$ lymphocytes. Nat. Immunol. 2, 316-324.

Feske, S., Okamura, H., Hogan, P.G., et al., 2003. Ca2+/calcineurin signaling in cells of the immune system. Biochem. Biophys. Res. Commun. 311, 1117-1132.

Fink, P.J., McMahan, C.J., 2000. Lymphocytes rearrange, edit and revise their antigen receptors to be useful yet safe. Immunol. Today 21, 561-566.

Fugmann, S.D., 2002. Breaking the seal. Nature 416, 691-694.

Gill, J., Malin, M., Sutherland, J., et al., 2003. Thymic generation and regeneration. Immunol. Rev. 195, 28-50.

Heissmeyer, V., Macian, F., Im, S.H., et al., 2004. Calcineurin imposes T-cell unresponsiveness through targeted proteolysis of signaling proteins. Nat. Immunol. 5, 238-240.

Junta, C.M., Passos, G.A.S., 1998. Emergence of TCR- $\alpha \beta$ V(D)J recombination and transcription during thymus ontogeny of inbred mouse strains. Mol. Cell. Biochem. 187, 67-72.

Lefranc, M.P., Lefranc, G., 2001. The T-Cell Receptor Facts Book, first ed. Academic Press, Suffolk.

Macedo, C., Junta, C.M., Passos, G.A.S., 1999. Onset of T-cell receptor $\mathrm{V} \beta 8.1$ and $\mathrm{D} \beta 2.1 \mathrm{~V}(\mathrm{D}) \mathrm{J}$ recombination during thymus development of inbred mouse strains. Immunol. Lett. 69, 371-373.

Mak, T.W., Penninger, J.M., Ohashi, P.S., 2001. Knockout mice: a paradigm shift in modern immunology. Nat. Rev. Immunol. 1, 11-19.

Muegge, K., Vila, M.P., Durum, S.K., 1993. Interleukin-7: a cofactor for V(D)J rearrangement of the T-cell receptor gene. Science 261, 93-95.

Nguyen, C., Rocha, D., Granjeaud, S., et al., 1995. Differential gene expression in the murine thymus assayed by quantitative hybridization of arrayed cDNA clones. Genomics 29, 207-215.

Quackenbush, J., 2002. Microarray data normalization and transformation. Nat. Genet. Supp. 32, 496-501.

Rugh, R., 1968. The Mouse. Its Reproduction and Development, first ed. Burgess Publishing Company, Edina, MN, USA.

Saha, S., Bardelli, A., Buckhaults, P., et al., 2001. A phosphatase associated with metastasis of colorectal cancer. Science 294, 1343-1346.

Shortman, K., Wu, L., 1996. Early T lymphocyte progenitors. Annu. Rev. Immunol. 14, 29-47.

Sollof, R.S., Wang, T.G., Dempsey, D., et al., 1997. Interleukin-7 induces $T C R$ gene rearrangement in adult marrow-resident murine precursor T-cells. Mol. Immunol. 34, 453-462.

Tusher, V.G., Tibshirani, R., Chu, G., 2001. Significance analysis of microarrays applied to the ionizing radiation response. Proc. Natl. Acad. Sci. U.S.A 98, 5116-5121.

Verdeil, G., Puthier, D., Nguyen, C., 2002. Gene profiling approach to establish the molecular bases for partial versus full activation of naïve CD8 T lymphocytes. Ann. N.Y. Acad. Sci. 975, 68-76. 


\title{
Promiscuous gene expression in the thymus: The root of central tolerance
}

\author{
DANIELLE A. R. MAGALHÃES ${ }^{1}$, EDUARDO L. V. SILVEIRA ${ }^{1}$, CRISTINA M. JUNTA ${ }^{1}$, \\ PAULA SANDRIN-GARCIA ${ }^{1}$, ANA LUCIA FACHIN ${ }^{1}$, EDUARDO A. DONADI ${ }^{2}$, \\ ELZA T. SAKAMOTO-HOJO ${ }^{3,4}$, \& GERALDO A. S. PASSOS ${ }^{1,5}$
}

${ }^{1}$ Molecular Immunogenetics Group, Department of Genetics, Faculty of Medicine, University of São Paulo (USP), 14040-900 Ribeirão Preto, SP, Brazil, ${ }^{2}$ Division of Clinical Immunology, Department of Medicine, Faculty of Medicine, USP, 14040-900 Ribeirão Preto, SP, Brazil, ${ }^{3}$ Laboratory of Cytogenetics and Mutagenesis, Department of Genetics, Faculty of Medicine USP, 14040-900 Ribeirão Preto, SP, Brazil, ${ }^{4}$ Department of Biology (FFCLRP), USP, 14040-900 Ribeirão Preto, SP, Brazil, and ${ }^{5}$ Discipline of Genetics, Department of Morphology, Faculty of Dentistry, USP, 14040-900, Ribeirão Preto, SP, Brazil

\begin{abstract}
The thymus is a complex organ with an epithelium formed by two main cell types, the cortical thymic epithelial (cTECs) and medullary thymic epithelial cells (mTECs), referred to as stroma. Immature thymocytes arising from the bone marrow, macrophages and dendritic cells also populate the thymus. Thymocytes evolve to mature $\mathrm{T}$ cells featuring cell differentiation antigens (CDs), which characterize the phenotypically distinct stages, defined as double-negative (DN), double positive (DP) and single positive (SP), based on expression of the coreceptors CD4 and CD8. The thymus is therefore implicated in $\mathrm{T}$ cell differentiation and during development into $\mathrm{T}$ cells thymocytes are in close association with the stroma. Recent evidence showed that mTECs express a diverse set of genes coding for parenchymal organ specific proteins. This phenomenon has been termed promiscuous gene expression (PGE) and has led to the reconsideration of the role of the thymus in central $\mathrm{T}$ cell tolerance to self-antigens, which prevents autoimmunity. The evidence of PGE is causing a reanalysis in the scope of central tolerance understanding. We summarize the evidence of PGE in the thymus, focusing particularly the use of cDNA microarray technology for the broad characterization of gene expression and demarcation of PGE emergence during thymus ontogeny.
\end{abstract}

Keywords: Autoimmunity, cDNA microarray, promiscuous gene expression, self-non-self discrimination, $T$ cell tolerance, thymus

\section{Considerations on self-non-self discrimination}

Self-non-self discrimination is an essential property of the immune system, which contributes to body homeostasis. The germinal idea of clonal selection theory and self-discrimination was developed by Paul Ehrlich more than 100 years ago (Ehrlich and Morgenroth 1901) and represents up to the present, the basic conceptual orientation for all immunological research.
In this regard, the direct demonstration of the clonal deletion of self-reactive lymphocytes is among the most important achievements, which has contributed to our contemporary understanding of self-tolerance in adaptive (Schwartz and Mueller 2003) and in innate (Medzhitov and Janeway 1997) immune systems (for further reading, see review of Kyewski and Derbinski 2004).

The two known pathways of immune response are characterized by the use of limited germline-encoded

Correspondence: G. A. S. Passos, Molecular Immunogenetics Group, Department of Genetics, Faculty of Medicine, University of São Paulo (USP), 14040-900, Ribeirão Preto, SP, Brazil. Tel: 5516360230 30. Fax: 5516363300 69. E-mail: passos@rge.fmrp.usp.br 
receptors for microbial components in the innate immune system or by highly diverse, somatically generated (somatic DNA rearrangements) antigenspecific $\mathrm{T}$ cell receptor (TCR) or immunoglobulin (Ig) receptors in adaptive immune system.

As an intellectual exercise, the heterodimeric TCR molecule (e.g. $\alpha / \beta$ TCR) could materialize the functional concept of the immune system due to their property in instantly recognizing the self major histocompatibility complex (MHC) and the non-self antigenic peptide.

Self-tolerance of the $\mathrm{T}$ cell repertoire is acquired during the development of immature $\mathrm{T}$ cells, a phenomenon dependent on the avidity of the interaction between specific TCR and self-peptideMHC ligands. The nascent $T$ cell repertoire in the thymus determines the diversity of self-antigens and the specificity of central self-tolerance. We agree with Kyewski and Derbinski (2004) in subsuming under central tolerance the intrathymic mechanisms, which $\mathrm{T}$ cells undergo in recognition of self-antigens. Accordingly, self-reactive regulatory $\mathrm{T}\left(\mathrm{T}_{\text {reg }}\right)$ cells are selected in the thymus, even though these cells play their role in the periphery.

In fact, all subsets of antigen-presenting cells (APCs), such as cortical thymic epithelial cells (cTECs), medullary thymic epithelial cells (mTECs), thymic dendritic cells and macrophages play their roles in presenting unique sets of selfpeptides, contributing to the diversity of self-antigens displayed in the thymus (Klein and Kyewski 2000).

However, the expression of tissue-specific antigens (TSAs) in the thymus, which represents a key feature for effecting self-representation, was only recently recognized. The evidence of thymic expression of TSAs in mice and humans, which has been referred to as promiscuous gene expression (PGE) (Jolicoeur et al. 1994; Derbinski et al. 2001; Gotter et al. 2004), reinforced the conception of central tolerance of tissue-specific self-antigens.

Prior to this evidence, the peripheral tolerance, that is, the mechanisms by which $\mathrm{T}$ cell selection towards TSAs occurs outside the thymus, dominated the scenario in explaining self-non-self discrimination (Alferink et al. 1999; Walker and Abbas 2002).

Promiscuous gene expression in the thymus is causing a reversal in the scope of central tolerance understanding, allowing for an unorthodox conception of the possible mechanisms of self-non-self discrimination (Kyewski et al. 2002; Gallegos and Bevan 2006).

The main implication of this heterogeneous gene expression in the thymus is associated with the maintenance of the immunological homeostasis in the body, controlling the pathogenic autoimmune reactions.

Evidence for this phenomenon was obtained using the reverse transcription-PCR (RT-PCR) method, which was biased towards antigens in autoimmune reactions, such as insulin, acetylcholine receptor or myelin basic protein. Today it is recognized that rather than selective, the set of expressed genes is as broad as possible, estimated to include up to $5-10 \%$ of all currently known mouse genes (Derbinski et al. 2001; Gotter et al. 2004; Kyewski and Derbinski 2004).

\section{Using the microarray technology}

At present, to explore the broad gene expression in the thymus, the choice strategy is the use of the microarray technology. The group of Kyewski and Derbinski (2004) from the German Cancer Research Centre in Heidelberg, Germany, has used the Affymetrics oligonucleotide microarray platform, which has allowed for extensive characterization of PGE in the mouse thymus.

In fact, large scale gene expression measurements by microarrays, in their different formats, such as, nylon membranes or glass slides have been used for more than 10 years to study the control of gene expression in the thymus, focusing mainly on thymocytes (Nguyen et al. 1995; Espanhol et al. 2004; Puthier et al. 2004; Magalhães et al. 2005; Cardoso et al. 2006).

The control of gene expression during the development of this organ has gained priority among several research teams, including our own group, allowing for the identification of candidate genes involved in thymopoiesis (Espanhol et al. 2004; Magalhães et al. 2005; Cardoso et al. 2006). A number of expressed sequence tags (ESTs) have been found that are modulated during the in vivo development of the thymus (Espanhol et al. 2004) and several cell-signaling genes, including those of the calcium cascade pathway, which is important for individual stages of $\mathrm{T}$ cell maturation and the control of anergy during thymus ontogeny (Magalhães et al. 2005).

Regarding in-lab cDNA microarray preparation for PGE research purposes in the mouse, of particular interest is the Soares thymus $2 \mathrm{NbMT}$ cDNA library constructed by Maria F. Bonaldo and Marcelo B. Soares of the Columbia University, New York, USA, in cooperation with Bertrand Jordan of the Centre d'Immunologie de Marseille-Luminy, France, whose researchers have made this library available at the IMAGE Consortium (http://image.llnl.gov). This is an EST normalized library, prepared from a C57Bl/6J 4 week-old male thymus and whose cDNA inserts, ranging from 0.5 to $1.5 \mathrm{~kb}$ in length, were cloned in the pT7T3D vector.

The library is composed of more than 25,000 resequenced clones representing most, if not the whole set of expressed genes by the mouse thymus, including those representing parenchymal and lymphoid organs. Thus, it represents a precious resource for preparing 
"specialized" thymus cDNA microarrays for further use in promiscuous gene expression determinations.

The work on gene expression of fetal mouse thymus realized by our group is performed using two cDNA microarray platforms; the first version is prepared on a glass slide containing 4500 target sequences per slide, which are hybridized with fluorescent cDNA probes labeled with Cy3 or Cy5. The second version is prepared on positively charged nylon membranes containing 750 target sequences, which are hybridized with radioactive cDNA probes labeled with ${ }^{33} \mathrm{P}$ isotope.

We defined as "complex probe", the labeled cDNA originated from thymus total RNA and as "target", the cloned sequences deposited in individual spots on the microarrays.

All target cDNA clones deposited on these two versions of microarrays are from the thymus $2 \mathrm{NbMT}$ normalized library mentioned above, which were previously amplified by PCR in 384- or 96-well plates using vector-PCR amplification with the following primers, which recognize the cloning vector: LBP 1S GTGGAATTGTGAGCGGATACC forward and LBP 1AS GCAAGGCGATTAAGTTGG reverse.

For both versions of microarrays, a Generation III array spotter (Amersham-Molecular DynamicsSunnyvale, CA, USA) is used according to the manufacturer's instructions and cross-linked using an ultraviolet cross-linker.

The cDNA probes are prepared by reverse transcription using $10 \mu \mathrm{g}$ of total RNA from fetal or adult thymus, which are labeled with $\mathrm{Cy} 3$ or $\mathrm{Cy} 5$ fluorochromes using the CyScribe post labeling kit (GE Healthcare, USA) and oligonucleotide $\mathrm{dT}_{12-18}$ as a primer. The $15 \mathrm{~h}$ period required for glass slide hybridization followed by washing is performed at $42^{\circ} \mathrm{C}$ in an automated slide processor (ASP, Amersham Biosciences) and the microarrays are scanned in a Generation III laser scanner (Amersham Biosciences).

The cDNA complex probes derived from fetal or adult thymus are Cy5-labeled. A Cy3-labeled cDNA pool, originated from a mix of equimolar amount of total RNA from different fetal organs (brain, liver, intestines and spleen), is used as reference in the twocolor hybridizations.

The nylon cDNA microarrays are hybridized with radiolabeled ${ }^{33} \mathrm{P}$-cDNA complex probes in a rolling oven at $65^{\circ} \mathrm{C}$ for $72 \mathrm{~h}$ and scanned in a phosphor imager storage system (Cyclone model, Packard Instruments, USA).

The characterization of each cDNA sequence is updated using the SOURCE genome data bank (http://genome-www5.stanford.edu/cgi-bin/source/ sourceSearch), providing information such as DNA and protein sequences, biological and molecular functions and chromosomal location.

\section{Preparing thymus tissue and total RNA for PGE experiments}

The classic Balb-c, $\mathrm{C} 57 \mathrm{Bl} / 6$ and ( + Balb-c $\times$ $\left.\mathrm{O}^{7} \mathrm{C} 57 \mathrm{~B} 1 / 6\right) \mathrm{F}_{1}$ mouse strains should be preferentially bred in an isolator with $0.45 \mu \mathrm{m}$ pore sized air filtered. To obtain timed pregnancies of Balb-c, C57Bl/6 and their hybrids at the developmental phase when TRBV8.1 V(D)J recombination occurs, the mice are mated and the day when the vaginal plug is observed at 7:00 am is considered to be day zero of gestation post coitum (p.c.). The pregnant mice are sacrificed preferentially by $\mathrm{CO}_{2}$ inhalation and the fetuses collected by surgery of the uterus. The p.c. age of fetuses should be confirmed by observing the morphological characteristics of each developmental phase (Rugh 1968).

The onset of TCR beta $\mathrm{V}(\mathrm{D}) \mathrm{J}$ recombination (TRBV8.1-BD2.1) during the in vivo fetal development of the thymus of Balb-c, C57B1/6 and their hybrids is taken on the basis of previously published data. Fetal thymus should be obtained at the emergence of $\mathrm{V}(\mathrm{D}) \mathrm{J}$ recombination, that is, at 1516 days p.c. for Balb-c and 14-15 days p.c. for C57Bl/6 and ( + Balb-c $\left.\times 0^{\top} \mathrm{C} 57 \mathrm{Bl} / 6\right) \mathrm{F}_{1}$ (Macedo et al. 1999; Magalhães et al. 2005).

The thymi should be removed from the fetuses preferable under a stereomicroscope and the epithelial cells preparation enriched on Percoll@ gradient centrifugation or purified by cell sorting, which are immediately processed for total RNA extraction.

In the microarray experiments, it is extremely important to use only undegraded and DNA-, protein- and phenol-free RNA preparations as verified by classic agarose gel electrophoresis stained with ethidium bromide and ultraviolet spectrophotometry, respectively.

\section{Analysing microarray data by statistical significance algorithm}

The gene expression data obtained from microarray experiments should be analysed by a mathematical/statistical algorithm. In PGE projects, we are using the significance analysis of microarrays method (SAM, available online at http://www-stat.stanford.edu/ tibs/ $\mathrm{SAM} / \mathrm{index} \cdot \mathrm{html}$ ) to analyse the significant variations in gene expression (Tusher et al. 2001). This method is based on $t$-test statistics, specially modified for high throughput analysis. We propose discussing only those genes which present a fold change expression $\geq 1$ (induced) and a false discovery rate (FDR) max. 0.05 (Table I, available online at http://rge.fmrp.usp.br/ passos/review/PGE/table1).

To analyse the significant variations in the gene expression of developing thymus, RNA samples are extracted on fixed days p.c. are compared with RNA from subsequent days of gestation. 


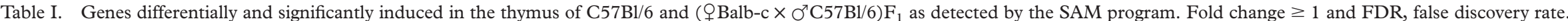
Magalhães et al. (2006) promiscuous gene expression in the thymus.

\begin{tabular}{|c|c|c|c|c|}
\hline Gene name & $\begin{array}{l}\text { GenBank } \\
\text { accession }\end{array}$ & Chromosomes & Predominant expression & Molecular/biological function \\
\hline
\end{tabular}

C57Bl/6 strain (fold change $=1.5$ and $F D R \sim 0.05$ )

Hexosaminidase B (Hexb)

NM_010422

Bromodomain containing 4

NM_020508 $(\operatorname{Brd} 4)$

Stimulated by retinoic acid 13 (Stra13)

NM_016665

$11 \mathrm{E} 2$

$\left(Q \mathrm{Balb}-\mathrm{c} \times \mathrm{O}^{7} \mathrm{C} 57 \mathrm{Bl} / 6\right) \mathrm{F}_{1}($ fold change $=1.0$ and $\mathrm{FDR} \sim 0.0012)$ Ets2 repressor factor (Erf) NM_010155

RAB2, member RAS oncogene

NM_021518
Adipose tissue, bone, amygdale, frontal cortex, trigeminal, cerebral cortex, dorsal root ganglia, dorsal striat um, hippocampus, hypothalamus, olfactory bulb, spinal

cord'lower, spinal cord upper, substantia nigra, blatocystis, placenta, small intestine, B220+B-cells, lymphnode, vomeronasal organ, salivary gland, pituitary, snout epidermis, thymus, thyroid, trachea, bladder, kidney

Adipose tissue, bone, bonemarrow, amygdala, preoptic, hippocampus, spinal cord'lower, embryo day 10.5 , embryo day 6.5, embryo day 7.5, embryo day 8.5 , embryo day 9.5, ovary, prostate, umbilical cord, uterus, heart, small intestine, B220+B-cells, CD4+ Tcells, CD8+ T cells, lung, lymphnode, pancreas, digits, snout epidermis, thymus, trachea

Adipose tissue, adrenalgland, bone, main olfactory epithelium, embryo day 6.5 , embryo day 9.5 , fertilized egg, ovary, prostate, testis, umbilical cord, uterus, oocyte, large intestine, B220+B-cells, CD4+ T cells, CD8+ T cells, liver, lung, vomeronasal organ, salivary gland, tongue, pituitary, digits, snout epidermis, spleen, thymus, trachea, kidney

Brown fat, bonemarrow, dorsal striatum, hippocampus, blastocysts, embryo day 10.5, embryo day 6.5, embryo day 7.5, embryo day 8.5 , embryo day 9.5 , fertilized egg, mammary gland (lact), ovary, placenta, heart, small intestine, liver, skeletal muscle, salivary gland, pancreas, spleen, stomach, thyroid, bladder

Adrenal gland, amygdala, frontal cortex, preoptic, trigeminal, cerebellum, cerebral cortex, dorsal root ganglia, dorsal striatum, hippocampus, hypothalamus, main olfactory ephitelium, olfactory bulb, spinal cord lower, spinal cord upper, substantia nigra, fertilized egg, ovary, prostate, oocyte, large intestine, lung, skeletal muscle, vomeronasal organ, pituitary, digits, epidermis, bladder, kidney, retina

\section{Metabolism}

\author{
(1)
}

Required maternally for proper expression of other homeotic genes involved in pattern formation, such as ubx

Transcriptional repressor (by similarity)

Required for protein transport from the endoplasmic reticulum to the golgi complex (by similarity) 


\begin{tabular}{|c|c|c|c|c|}
\hline Gene name & $\begin{array}{l}\text { GenBank } \\
\text { accession }\end{array}$ & Chromosomes & Predominant expression & Molecular/biological function \\
\hline $\begin{array}{l}\text { Membrane associated DNA binding protein } \\
\text { (Mnab) }\end{array}$ & XM_130233 & 2 & $\begin{array}{l}\text { Adrenal gland, amygdala, frontal cortex, preoptic, } \\
\text { trigeminal, cerebellum, cerebral cortex, dorsal } \\
\text { root ganglia, dorsal striatum, hippocampus, } \\
\text { hypothalamus, main olfactory ephitelium, olfactory bulb, } \\
\text { spinal cord lower, substantia nigra, embryo } \\
\text { day 10.5, ovary, prostate, umbilical cord, lung, skeletal } \\
\text { muscle, vomeronasal organ, tongue, pituitary, digits, } \\
\text { epidermis, thymus, trachea, bladder, retina }\end{array}$ & Nucleic acid binding \\
\hline RAD51-like 1 (S. cerevisiae) (Rad5111) & NM_009014 & $12 \mathrm{C} 3$ & $\begin{array}{l}\text { Brown fat, bonemarrow, dorsal striatum, embryo day 9.5, } \\
\text { fertilized egg, mammary gland (lact), ovary, placenta, } \\
\text { testis, uterus, B220+B-cells, CD } 4+\text { Tcells, salivary } \\
\text { gland, pancreas, spleen, stomach, thyroid, trachea }\end{array}$ & DNA repair (by similarity) \\
\hline $\begin{array}{l}\text { Small chemokine (C-C motif) ligand } 11 \\
(\mathrm{Ccl11})\end{array}$ & NM_011330 & 11 & $\begin{array}{l}\text { Brown fat, adipose tissue, trigeminal, ovary, prostate, } \\
\text { uterus, large intestine, small intestine, lymphnode, } \\
\text { skeletal muscle, tongue, digits, epidermis, snout } \\
\text { epidermis, stomach, thymus, thyroid, trachea, bladder }\end{array}$ & Immune response by eosinophils \\
\hline $\begin{array}{l}\text { DEAD (Asp-Glu-Ala-Asp) box polypeptide } \\
21 \text { (Ddx21) }\end{array}$ & NM_019553 & 10 & $\begin{array}{l}\text { Adipose tissue, adrenal gland, bone, blastocysts, embryo } \\
\text { day } 10.5 \text {, embryo day } 6.5 \text {, embryo day } 7.5 \text {, embryo } \\
\text { day } 8.5 \text {, embryo day } 9.5 \text {, mammary gland (lact), ovary, } \\
\text { prostate, umbilical cord, uterus, larger intestine, } \\
\text { B220+B-cells, CD4+ Tcells, CD8+ Tcells, lung, } \\
\text { lymphnode, salivary gland, tongue, digits, epidermis, } \\
\text { spleen, thymus, trachea, bladder }\end{array}$ & $\begin{array}{l}\text { Nucleic acid binding RNA helicase/foldase } \\
\text { (by similarity) }\end{array}$ \\
\hline Sodium channel modifier 1 (Scnm1) & NM_027013 & 3 & $\begin{array}{l}\text { Brown fat, frontal cortex, preoptic, trigeminal, hippo- } \\
\text { campus, hypothalamus, main olfactory ephitelium, spinal } \\
\text { cord lower, substantia nigra, blastocysts, embryo day } \\
\text { 10.5, embryo day } 6.5 \text {, embryo day } 7.5 \text {, embryo } \\
\text { day 9.5, ovary, testis, heart, B220+B-cells, } \\
\text { CD4+ Tcells, CD8+ Tcells, tongue, pituitary, digits, } \\
\text { snout epidermis, thymus, trachea }\end{array}$ & Ion channel activity and RNA splicing \\
\hline Sialophorin (Spn) & NM_009259 & 7 & $\begin{array}{l}\text { Bone, bonemarrow, embryo day } 10.5 \text {, embryo day } 6.5 \text {, } \\
\text { embryo day } 7.5 \text {, embryo day 9.5, placenta, B220 + } \\
\text { B-cells, CD } 4+\text { Tcells, CD }+ \text { Tcells, lung, } \\
\text { lymphnode, spleen, thymus, trachea }\end{array}$ & $\begin{array}{l}\text { Negative regulatory role in adaptive immune response } \\
\text { (by similarity) }\end{array}$ \\
\hline Adenosine deaminase (Ada) & NM_007398 & 2 & Placenta, small intestine, tongue, thymus, trachea & Immune response, nucleotide metabolism \\
\hline Ecotropic viral integration site $2^{\mathrm{a}}$ (Evi2a) & NM_010161 & 11 & $\begin{array}{l}\text { Brown fat,bone, bonemarrow, dorsal striatum, } \\
\text { hippocampus, spinal cord upper, blastocysts, embryo day } \\
\text { 10.5, embryo day } 6.5 \text {, embryo day } 7.5 \text {, embryo } \\
\text { day } 9.5 \text {, mammary gland (lact), oocyte, heart, CD } 8+ \\
\text { Tcells, liver, lymphnode, pancreas, epidermis, spleen, } \\
\text { stomach, thymus, thyroid, trachea }\end{array}$ & - \\
\hline
\end{tabular}




\section{Gene name}

B-cell leukemia/lymphoma 6 (Bcl6)

accession

Chr

Chromosomes

Predominant expression

Molecular/biological function

NM_009744 $16 \quad$ Adipose tissue, adrenal gland, bone, cerebellum, hippo-

campus, main olfactory ephitelium, olfactory bulb, spinal

cord lower, spinal cord upper, ovary, prostate, uterus,

B220+B-cells, lymphnode, skeletal muscle, salivary

gland, digits, epidermis, snout epidermis, thymus,

trachea, kidney, retina

Interleukin 16 (I116)

Chemokine (C-X-C motif) ligand 4 (Cxcl4)

Microtubule-associated protein, $\mathrm{RP} / \mathrm{EB}$ family, member 2 (Mapre2)

WAP, follistatin/kazal, immunoglobulin, kunitz and netrin domain containing 2 (Wfikkn2)

Signal transducer and activator of

transcription 1 (Stat1)

C-type lectin domain family 1 , member b (Clec1b) (Clec2)

Exportin, tRNA (nuclear export receptor for tRNAs) (Xpot)
NM_010551

Adipose tissue, cerebellum, B220+B-cells, CD4+ Tcells, CD8+ Tcells, lymphnode, spleen, thymus, trachea

Adipose tissue, bone, bonemarrow, trigeminal, ovary, umbilical cord, heart, lung, skeletal muscle, vomeronasal organ, tongue, digits, epidermis, snout epidermis, spleen, trachea, bladder

NM_153058 18 A2 Brown fat, bonemarrow, dorsal striatum, blastocysts, embryo day 10.5 , embryo day 6.5 , embryo day 7.5 , embryo day 9.5 , mammary gland (lact), placenta, prostate, heart, small intestine, liver, lung, lymphnode, skeletal muscle, salivary gland, pancreas, spleen, stomach, thyroid, bladder

NM_181819 11D Adipose tissue, prostate, umbilical cord, uterus, CD4+ Tcells, CD8+ Tcellslung, lymphnode, longue, digits, epidermis, thymus

NM_009283

NM_019985

$6 \mathrm{~F} 3$

XM 125902

Adipose tissue, adrenal gland, bone, bonemarrow, trigeminal, dorsal root ganglia, ovary, uterus, B220+Bcells, CD4+ Tcells, CD8+ Tcells, lung, lymphnode, pancreas, spleen, thymus, thyroid, trachea

Bone, bonemarrow, embryo day 10.5 , placenta, liver, lymphnode, pancreas, spleen, trachea

Adrenal gland, amygdale, frontal cortex, preoptic, cerebellum, cerebral cortex, dorsal root ganglia, hippocampus, hypothalamus, olfactory bulb, spinal cord lower, spinal cord upper, substantia nigra, blastocysts, embryo day 10.5, embryo day 6.5, embryo day 7.5, embryo day 9.5,

mammary gland (lact), ovary, prostate, umbilical cord, uterus, lung, longue, digits, thymus, trachea

Adrenal gland, preoptic, trigeminal, cerebellum, cerebral cortex, dorsal root ganglia, olfactory bulb, substantia nigra, blastocysts, embryo day 10.5 , embryo day 6.5 , embryo day 9.5, fertilized egg, ovary, prostate, uterus, oocyte, CD4+ Tcells, longue, digits, snout epidermis, thymus, trachea
Transcription factor

Cytokine activity, immune cell chemotaxis

Platelet factor 4, is released during platelet aggregation

Microtubule binding and protein binding

Alpha-1-microglobulin occurs in many physiological fluids including plasma, urine, and cerebrospinal fluid (by similarity)

Transcription factor

Cell surface receptor linked signal transduction

Mediates nuclear export of all tRNAs (by similarity) 


\begin{tabular}{|c|c|c|c|c|}
\hline Gene name & $\begin{array}{l}\text { GenBank } \\
\text { accession }\end{array}$ & Chromosomes & Predominant expression & Molecular/biological function \\
\hline Activating transcription factor 4 (Atf4) & NM_009716 & 15 & $\begin{array}{l}\text { Adrenal gland, cerebellum, main olfactory epithelium, } \\
\text { blastocysts, embryo day } 6.5 \text {, embryo day } 7.5 \text {, embryo day } \\
9.5 \text {, placenta, umbilical cord, uterus, oocyte, large } \\
\text { intestine, B220+B-cells, CD } 4+\text { Tcells, lung, skeletal } \\
\text { muscle, vomeronasal organ, salivary gland, tongue, } \\
\text { pituitary, digits, snout epidermis, thymus, trachea, retina }\end{array}$ & Transcription factor \\
\hline Zinc finger protein 131 (Zfp131) & NM_028245 & 13 & $\begin{array}{l}\text { Adipose tissue, adrenal gland, bone, bonemarrow, amyg- } \\
\text { dale, frontal cortex, cerebellum, embryo day 9.5, } \\
\text { fertilized egg, ovary, uterus, oocyte, large intestine, } \\
\text { B220+B-cells, CD4+ Tcells, CD8+ Tcells, lung, } \\
\text { lymphnode, skeletal muscle, digits, thymus, trachea }\end{array}$ & May be involved in transcriptional regulation \\
\hline
\end{tabular}

Adipose tissue, bone, bonemarrow, preoptic, blastocys
ovary, umblical cord, lymphnode, longue, digits,
epidermis, snout epidermis, thymus*, trachea

Adipose tissue, adrenalgland, bone, main olfactory

epithelium, spinal cord'lower, spinal cord upper, fertilized egg, ovary, placenta, prostate, uterus, oocyte, heart, large intestine, small intestine, B220+ B cells, lung, skeletal muscle, vomeronasal organ, salivary gland, tongue, digits, epidermis, snout epidermis, stomach, trachea, bladder,

\section{WD repeat and SOCS box-containing 2} (Wsb2)

\section{POU domain, class 2, associating factor 1} (Pou2af1)

Transformed mouse 3T3 cell double minute $2(\mathrm{Mdm} 2)$
NM_021539

NM_011136

NM_010786

9 A5.3 kidney, retina

Adrenal gland, amygdale, frontal cortex, preoptic, trigeminal, cerebellum, cerebral cortex, dorsal root ganglia, dorsal striatum, hippocampus, hypothalamus, main olfactory ephitelium, olfactory bulb, spinal cord lower, spinal cord upper, substantia nigra, ovary, placenta, umbilical cord, uterus, large intestine, lymphnode, skeletal muscle, vomeronasal organ, pancreas, pituitary, spleen, kidney

Adipose tissue, bone, bonemarrow, B220+B-cells, CD4+ Tcells, CD8+ Tcells, lymphnode, spleen, trachea Adrenal gland, amygdale, preoptic, spinal cord lower, substantia nigra, blastocysts, embryo day 6.5 , embryo day 8.5, embryo day 9.5, fertilized egg, placenta, testis, oocyte, B220+B-cells, CD4+ Tcells, CD8+ Tcells, lung, lymphnode, skeletal muscle, vomeronasal organ, thymus, trachea

Brown fat, bonemarrow, dorsal striatum, hippocampus, embryo day 10.5, embryo day 7.5, embryo day 9.5, fertilized egg, mammary gland (lact), placenta, testis, heart, large intestine, small intestine, liver, skeletal

muscle, salivary gland, longue, pancreas, spleen, stomach, thyroid, bladder, kidney
Required for protein transport in the secretory pathway

Transport, transporter activity

Intracellular signaling cascade

\section{DNA binding, regulation of transcription}

Cell growth and/or maintenance

Participates in at least several b-cell activation processes as well as of other cell types 


\section{Gene name}

Protein O-fucosyltransferase 2 (Pofut2)

accession

Chromosomes

NM_030262

$10 \mathrm{C} 1$

Predominant expression

Brown fat, Adipose tissue, adrenal gland, preoptic

cerebellum, main olfactory epithelium, embryo day 6.5,

embryo day 7.5, embryo day 8.5, embryo day 9.5,

fertilized egg, ovary, placenta, testis, umbilical cord,

uterus, oocyte, lung, vomeronasal organ, pituitary, snout

epidermis

CD24a antigen $(\mathrm{Cd} 24 \mathrm{a})$

NM_009846

Transcription factor E2a (Tcfe2a)

NM_011548

Adipose tissue, bone, bonemarrow, trigeminal, dorsal root ganglia, main olfactory epithelium, embryo day 10.5 , embryo day 8.5, embryo day 9.5, mammary gland (lact), ovary, prostate, uterus, large intestine, B220+B-cells,

lung, skeletal muscle, vomeronasal organ, salivary gland, longue, digits, spleen, stomach, thymus, thyroid, trachea, kidney, retina

Adipose tissue, adrenal gland, bone, bonemarrow,

cerebellum, main olfactory epithelium, embryo day 10.5, embryo day 6.5, embryo day 7.5, embryo day 8.5, embryo day 9.5, fertilized egg, ovary, umbilical cord, uterus, oocyte, B220+B-cells, CD4+ Tcells, CD8+ Tcells,

lymphnode, pituitary, digits, epidermis, snout epidermis, spleen, thymus, trachea, bladder

Interferon-induced protein with tetratricopeptide repeats 2 (Ifit2)

NM_008332

19C1

Adipose tissue, adrenal gland, bone, retina, bonemarrow, trigeminal, dorsal root ganglia, hypothalamus, main olfactory epithelium, olfactory bulb, spinal cord lower, substantia nigra, ovary, placenta, prostate, uterus, heart, large intestine, B220+B-cells, CD4+ Tcells, CD8+ Tcells, lung, lymphnode, vomeronasal organ, epidermis, spleen, thymus, trachea, kidney

Cut-like 1 (Drosophila) (Cutil)

NM_009986

Brown fat, adrenalgland, bonemarrow, frontal cortex, preoptic, cerebellum, dorsal striatum, main olfactory epithelium, olfactory bulb, spinal cord'lower, substantia nigra, embryo day 10.5, embryo day 7.5, embryo day 8.5, embryo day 9.5, fertilized egg, mammary gland (lact), placenta, umbilical cord, uterus, heart, large intestine, small intestine, liver, lung, skeletal muscle, omeronasal organ, salivary gland, tongue, pancreas, digits, epidermis, snout epidermis, spleen, stomach, thymus, thyroid, bladder, kidney, retina

Histocompatibility 2, complement com-

NM_008198 ponent factor $\mathrm{B}(\mathrm{H} 2-\mathrm{Bf})$

Fanconi anemia, complementation group $\mathrm{G}$

NM_053081 (Fancg) intestine, liver, lymphnode, digits, epidermis, snout epidermis, spleen, trachea, kidney

4B1 Bone, bonemarrow, fertilized egg, testis, oocyte, B220+Bcells, CD4+ Tcells, CD8+ Tcells, salivary gland, longue, digits, snout epidermis, thymus, trachea
Adipose tissue, ovary, uterus, large intestine, small
Molecular/biological function

Carbohydrate metabolism

May have a pivotal role in cell differentiation

Transcription factor

Immune response

Probably has a broad role in mammalian development as a repressor of developmentally regulated gene expression

Factor B which is part of the alternate pathway of the complement system

Binding,DNA repair, response to DNA damage stimulus, response to radiation, spermatid development

\section{$\varnothing$}




\begin{tabular}{|c|c|c|c|c|}
\hline Gene name & $\begin{array}{l}\text { GenBank } \\
\text { accession }\end{array}$ & Chromosomes & Predominant expression & Molecular/biological function \\
\hline Ras homolog gene family, member A (Rhoa) & NM_016802 & 9 & $\begin{array}{l}\text { Adipose tissue, adrenal gland, bone, dorsal root ganglia, } \\
\text { main olfactory epithelium, embryo day } 10.5 \text {, embryo day } \\
6.5 \text {, embryo day } 7.5 \text {, embryo day } 8.5 \text {, embryo day } 9.5 \text {, } \\
\text { ovary, prostate, umbilical cord, uterus, heart, large } \\
\text { intestine, small intestine, B220+B-cells, CD } 4+\text { Tcells, } \\
\text { CD } 8+\text { Tcells, lung, vomeronasal organ, digits, snout } \\
\text { epidermis, stomach, thymus, trachea, bladder, kidney }\end{array}$ & $\begin{array}{l}\text { Regulates a signal transduction pathway linking plasma } \\
\text { membrane receptors to the assembly of focal adhesions } \\
\text { and actin stress fibers }\end{array}$ \\
\hline $\begin{array}{l}\text { Interferon-induced protein with tetratrico- } \\
\text { peptide repeats } 1 \text { (Ifit1) }\end{array}$ & NM_008331 & 19C1 & $\begin{array}{l}\text { Brown fat, Adipose tissue, adrenal gland, bone, bone- } \\
\text { marrow, trigeminal, dorsal root ganglia, main olfactory } \\
\text { epithelium, ovary, placenta, prostate, uterus, heart, large } \\
\text { intestine, small intestine, CD } 4+\text { Tcells, CD } 8+\text { Tcells, } \\
\text { liver, lung, lymphnode, vomeronasal organ, longue, } \\
\text { pancreas, epidermis, spleen, thymus, trachea, bladder, } \\
\text { retina }\end{array}$ & Immune response \\
\hline $\begin{array}{l}\text { Growth factor receptor bound protein } 2 \\
\text { (Grb2) }\end{array}$ & NM_008163 & 11 & $\begin{array}{l}\text { Bone, bonemarrow, preoptic, cerebellum, cerebral cortex, } \\
\text { dorsal root ganglia, dorsal striatum, hippocampus, } \\
\text { hypothalamus, olfactory bulb, spinal cord'lower, sub- }\end{array}$ & $\begin{array}{l}\text { MAPKKK cascade, protein binding, Ras protein signal } \\
\text { transduction, } \mathrm{SH} 3 / \mathrm{SH} 2 \text { adaptor activity }\end{array}$ \\
\hline
\end{tabular}
hypothalamus, olfactory bulb, spinal cord'lower, substantia nigra, embryo day 10.5 , embryo day 6.5 , embryo day 7.5 , embryo day 8.5 , embryo day 9.5 , heart, B220+ B cells, CD4+ T cells, CD8+ T cells, lymphnode, tongue, epidermis, snout epidermis cerebellum, córtex cerebral, dorsal striatum, hippocampus, hypothalamus, olfactory bulb, spinal cord lower, spinal cord upper, substantia nigra embryo day 7.5, embryo day 9.5, placenta, lung, salivary gland, pancreas, pituitary, spleen, stomach, thyroid, retina

Tumor necrosis factor receptor superfamily, NM_009452 member 4 (Tnfrsf4)

Wiskott-Aldrich syndrome protein interacting protein (Waspip) (tissue, main olfactory epithelium, testis, heart, small intestine, B220+B-cells, CD4+ Tcells, lymphnode, skeletal muscle, epidermis, snout epidermis, trachea, kidney

2 Adipose tissue, bone, bonemarrow, dorsal root ganglia, spinal cord lower, blastocysts, embryo day 10.5 , mammary gland (lact), umbilical cord, uterus, heart, B220+B-cells, CD4+ Tcells, CD8+ Tcells, lung, lymphnode, vomeronasal organ, longue, digits, snout epidermis, spleen, thymus, trachea, bladder transduction, $\mathrm{SH} 3 / \mathrm{SH} 2$ adaptor activity

The $\mathrm{H} 3$ subclass of histamine receptors could mediate the histamine signals in CNS and peripheral nervous system (by similarity)

Cellular defense response,inflammatory response

Actin binding, actin filament-based movement 


Gene name
BCL2/adenovirus E1B 19 kDa-interacting
protein 1, NIP3 (Bnip3)

GenBank

accession

Chromosomes

7F5

protein 1, NIP3 (Bnip3)

PTK2 protein tyrosine kinase 2 beta (Ptk2b) NM_172498

SMT3 suppressor of mif two 3 homolog 3 (yeast) (Sumo3)

Tumor necrosis factor receptor superfamily, member 13b (Tnfrsf13b)

Non-catalytic region of tyrosine kinase adaptor protein $2(\mathrm{Nck} 2)$

T-cell receptor gamma, variable 4 (Tcrg-V4)

Z12299.1

F-box protein 45 (Fbxo45)

NM_019929

NM_021349
Brown fat, Adipose tissue, adrenal gland, frontal cortex,

trigeminal, cerebral cortex, dorsal root ganglia, hypothalamus, spinal cord lower, spinal cord upper, substanti nigra, blastocysts, embryo day 6.5, embryo day 8.5, ferlized egg, ovary, placenta, prostate, umbilical cord,

oocyte, heart, liver, skeletal muscle, vomeronasal organ, longue, pituitary, epidermis, trachea, kidney

Adipose tissue, bone, bonemarrow, amygdale, frontal cortex, cerebral cortex, dorsal striatum, hippocampus, olfactory bulb, large intestine, B220+B-cells, CD4+

Tcells, CD8+ Tcells, lymphnode, spleen, thymus, trachea

antic, cerebellum, hypothalamus, main olfactory epithelium, olfactory bulb, spinal cord lower, substantia nigra, , blastocysts, embryo day 6.5, embryo day 8.5 , embryo day 9.5 , embryo day 10.5 ferlized egg, ovary, prostate, umbilical cord, uterus, oocyte, vomeronasal organ, pituitary, digits, snout epidermis, thymus, trachea, retina

Adipose tissue, bone, bonemarrow, B220+B-cells, CD4+ Tcells, CD8+ Tcells, lung, lymphnode, spleen, thymus, trachea

NM_010879 1C1 Adipose tissue, adrenal gland, cerebral cortex, hippocampus, main olfactory epithelium, olfactory bulb, blastocysts, embryo day 9.5, embryo day 10.5, ovary, placenta, prostate, umbilical cord, uterus, heart, large intestine, small intestine, CD4+ Tcells, CD8+ Tcells, lung, vomeronasal organ, tongue, snout epidermis, stomach, thymus, trachea, bladder

Brown fat, Adipose tissue, bonemarrow, dorsal striatum, heart, large intestine, small intestine, CD4+ Tcells, CD8+ Tcells, liver, lymphnode, epidermis, spleen, thymus, trachea

Adipose tissue, adrenal gland, bone, amygdala, frontal cortex trigeminal, cerebral cortex, cerebellum, dorsal root ganglia, hippocampus, main olfactory epithelium, olfactory bulb, spinal cord lower, substantia nigra, blastocysts, embryo day 9.5, embryo day 10.5, ovary, heart, skeletal muscle vomeronasal organ, tongue, pituitary, digits, epidermis, snout epidermis spleen, thymus, trachea, retina

\section{Molecular/biological function}

Binds to the adenovirus e $1 \mathrm{~b} 19 \mathrm{kda}$ protein or to bcl-2. may play a role in repartitioning calcium between the two major intracellular calcium stores in association with the $19 \mathrm{kda}$ or bcl-2 proteins

Involved in calcium induced regulation of ion channel and activation of the map kinase signaling pathway

Protein modification, ubiquitin cycle

B cell homeostasis, immune response, negative regulation of B cell proliferation

Actin filament organization, cell migration, epidermal growth factor receptor signaling pathway

\section{Cellular defense response}

Ubiquitin cycle 


\section{Gene name}

Protein kinase, interferon inducible double stranded RNA dependent activator (Prkra)

\section{GenBank}

NM_011871

NM_145390 8C2
Chromosomes

Predominant expression

Molecular/biological function

C3

Adipose tissue, adrenal gland, bone, preoptic, trigeminal, dorsal root ganglia, hypotalamus, spinal cord upper,

spinal cord lower, substantia nigra, embryo day 7.5,

embryo day 8.5, embryo day 9.5, embryo day 10.5, ovary, testis, umbilical cord, uterus, heart, large intestine, small intestine, liver, lung, pituitary, stomach, trachea, bladder, kidney, retina

Bone, bonemarrow, amygdale, preoptic, cerebellum, cerebral cortex, dorsal striatum, hippocampus, hypotalamus, main olfactory epithelium, olfactory bulb, spinal cord lower, substantia nigra, blastocysts, embryo day 10.5 , embryo day embryo day 9.5 , prostate, oocyte, large intestine, small intestine, B220+B-cells, CD4+ Tcells, lung, lymphnode, pituitary, digits, snout epidermis, thymus, bladder, retina

Brown fat, Adipose tissue, bone, amygdale, frontal cortex, trigeminal, cerebellum, dorsal striatum, hypotalamus, spinal cord lower, embryo day 7.5, fertilized egg, mammary gland, placenta, uterus, oocyte, heart,

B220+B-cells, liver, lymphnode, salivary gland, pancreas, digits, epidermis, spleen, thymus, thyroid

Amygdale, frontal cortex, preoptic, trigeminal, cerebellum, cerebral cortex, dorsal root ganglia, dorsal striatum, hippocampus, hypotalamus, main olfactory epithelium, olfactory bulb, spinal cord upper, spinal cord lower, substantia nigra, blastocysts, embryo day 6.5 , embryo day 7.5 , embryo day 9.5, ovary, prostate, vomeronasal organ, tongue, digits, snout epidermis, thymus

NM_009045 19 Adipose tissue, adrenal gland, bone, cerebellum, main olfactory epithelium, fertilized egg, ovary, placenta, prostate, testis, umbilical cord, uterus, oocyte, B220+Bcells, CD4+ Tcells, CD8+ Tcells, lung, lymphnode,

vomeronasal organ, tongue, pituitary, digits, epidermis, snout epidermis, spleen, thymus, trachea, bladder, retina Brown fat, Adipose tissue, amygdala, frontal cortex, preoptic, cerebellum, cerebral cortex, hippocampus, hypotalamus, main olfactory epithelium, olfactory bulb, spinal cord upper, spinal cord lower, substantia nigra, prostate, testis, heart, large intestine, small intestine, lung, skeletal muscle, vomeronasal organ, tongue, epidermis, snout epidermis, stomach, thymus, thyroid, kidney
Double-stranded RNA binding, kinase activity, protein amino acid phosphorylation

Tyrosine kinase of the non-receptor type, involved in the ifn-alpha/beta/gamma signal pathway

\section{Required for import of mRNA binding proteins}




\section{Gene name}

accession

Toll-like receptor $4(\mathrm{Tl} 4)$

Brown fat, Adipose tissue, bone, bonemarrow, main

olfactory epithelium, mammary gland, prostate, umbilical cord, uterus, heart, large intestine, B220+B-cells, liver, lung, lymphnode, skeletal muscle, vomeronasal organ, salivary gland, tongue, pancreas, digits, epidermis, spleen, stomach, thyroid, trachea, bladder

Zinc finger protein 143 (Zfp143)

NM_009281

Interleukin 2 receptor, gamma chain (Il2rg)

NM_013563

$\mathrm{X}$

Brown fat, Adipose tissue, bone, bonemarrow, cerebellum, main olfactory epithelium, embryo day 10.5 , embryo day 6.5, embryo day 7.5, embryo day 8.5, embryo day 9.5,

fertilized egg, ovary, testis, umbilical cord, uterus, oocyte, heart, B220+B-cells, CD4+ Tcells, CD8+ Tcells, lymphnode, skeletal muscle, vomeronasal organ, salivary gland, digits, snout epidermis, spleen, thymus, thyroid, trachea

Adipose tissue, bone, bonemarrow, embryo day 6.5, embryo day 7.5, heart, B220+B-cells, CD4+ Tcells, CD8+ Tcells, lung, lymphnode, skeletal muscle, epidermis, spleen, thymus, trachea

UDP-GlcNAc:betaGal beta-1,3-N-acetyl- $\quad$ NM 016888 glucosaminyltransferase 1 (B3gnt1)

Splicing factor $3 b$, subunit 1 (Sf3b1)

NM_031179 1

Adipose tissue, adrenal gland, bone, amygdale, frontal cortex, trigeminal, dorsal root ganglia, dorsal striatum, hypotalamus, main olfactory epithelium, embryo day 6.5, fertilized egg, ovary, prostate, uterus, oocyte, large intestine, small intestine, B220+B-cells, CD4+ Tcells, CD8+ Tcells, lung, lymphnode, vomeronasal organ, pituitary, digits, snout epidermis, stomach, thymus, trachea, bladder, kidney

Adipose tissue, adrenal gland, bonemarrow, amygdale, frontal cortex, preoptic, trigeminal, cerebellum, cerebral cortex, dorsal striatum, hippocampus, hypotalamus, main olfactory epithelium, olfactory bulb, spinal cord upper, spinal cord lower, substantia nigra, embryo day 10.5 embryo day 6.5, embryo day 8.5, embryo day 9.5, fertilized egg, ovary, umbilical cord, uterus, oocyte, heart, B220+B-cells, CD4+ Tcells, lung, pituitary, thymus, trachea, bladder, kidney, retina

Lymphoid enhancer binding factor 1 (Lef1) NM_010703
Brown fat, bonemarrow, blastocysts, embryo day 10.5, embryo day 6.5, embryo day 7.5, embryo day 8.5, embryo day 9.5, fertilized egg, mammary gland, placenta, prostate, testis, umbilical cord, heart, small intestine, B220+Bcells, CD4+ Tcells, CD8+ Tcells, liver, lymphnode, skeletal muscle, salivary gland, pancreas, spleen, stomach, thymus, thyroid, bladder, kidney
Activation of NF-kappaB-inducing kinase, catalytic activity, I-kappaB kinase/NF-kappaB cascade, immune response, inflammatory response

Transcriptional activator. binds to the sph motif of small nuclear rna (snRNA) gene promoters

Cell surface receptor linked signal transduction

Axon guidance, galactosyltransferase activity, manganese ion binding, protein amino acid glycosylation, sensory perception of smell

Subunit of the splicing factor sf3b required for "a" complex assembly formed by the stable binding of u2 snrnp to the branchpoint sequence (bps) in pre-mRNA

Transcriptional activator 


\begin{tabular}{|c|c|c|c|c|}
\hline Gene name & $\begin{array}{l}\text { GenBank } \\
\text { accession }\end{array}$ & Chromosomes & Predominant expression & Molecular/biological function \\
\hline $\begin{array}{l}\text { Solute carrier family } 12 \text {, member } 6 \\
\text { (Slc12a6) }\end{array}$ & NM_133649 & $2 \mathrm{E} 3$ & $\begin{array}{l}\text { Brown fat, bonemarrow, dorsal striatum, hippocampus, } \\
\text { hypotalamus, olfactory bulb, substantia nigra, blastocysts, } \\
\text { embryo day } 10.5 \text {, embryo day } 6.5 \text {, embryo day } 7.5 \text {, } \\
\text { embryo day } 8.5 \text {, embryo day } 9.5 \text {, fertilized egg, mammary } \\
\text { gland, placenta, testis, oocyte, heart, large intestine, small } \\
\text { intestine, B220+B-cells, CD4+ Tcells, liver, lymphnode, } \\
\text { skeletal muscle, salivary gland, pancreas, epidermis, } \\
\text { spleen, stomach, thymus, thyroid, bladder, kidney }\end{array}$ & Amino acid transport \\
\hline Angio-associated migratory protein (Aamp) & NM_146110 & $1 \mathrm{C} 4$ & $\begin{array}{l}\text { Adipose tissue, adrenal gland, amygdale, preoptic, } \\
\text { cerebellum, cerebral cortex, dorsal root ganglia, hippo- } \\
\text { campus, hypotalamus, main olfactory epithelium, } \\
\text { olfactory bulb, spinal cord lower, substantia nigra, } \\
\text { embryo day 6.5, ovary, placenta, prostate, testis, uterus, } \\
\text { B220+B-cells, CD4+ Tcells, CD8+ Tcells, lymphnode, } \\
\text { vomeronasal organ, pituitary, digits, snout epidermis, } \\
\text { thymus, bladder, kidney }\end{array}$ & - \\
\hline $\begin{array}{l}\text { Nuclear factor of activated T-cells, cyto- } \\
\text { plasmic, calcineurin-dependent } 1 \\
\text { (Nfact1) }\end{array}$ & NM_016791 & 18 & $\begin{array}{l}\text { Brown fat, Adipose tissue, bone, bonemarrow, main } \\
\text { olfactory epithelium, fertilized egg, umbilical cord, } \\
\text { B220+B-cells, CD4+ Tcells, CD } 8+\text { Tcells, lung, } \\
\text { lymphnode, skeletal muscle, vomeronasal organ, salivary } \\
\text { gland, tongue, pancreas, digits, epidermis, snout } \\
\text { epidermis, spleen, stomach, thymus, thyroid, trachea }\end{array}$ & $\begin{array}{l}\text { Plays a role in the inducible expression of cytokine genes in } \mathrm{t} \\
\text { cells (by similarity) }\end{array}$ \\
\hline Actin-binding LIM protein 1 (Ablim1) & NM_178688 & 19 & $\begin{array}{l}\text { Brown fat, Adipose tissue, amygdale, preoptic, trigeminal, } \\
\text { cerebellum, dorsal root ganglia, olfactory bulb, spinal } \\
\text { cord lower, substantia nigra, ovary, umbilical cord, heart, } \\
\text { large intestine, B220+B-cells, CD } 4+\text { Tcells, CD } 8+ \\
\text { Tcells, lung, lymphnode, vomeronasal organ, tongue, } \\
\text { digits, epidermis, snout epidermis, spleen, stomach, } \\
\text { thymus, thyroid, trachea, retina }\end{array}$ & $\begin{array}{l}\text { Actin binding, axon guidance, cytoskeleton organization } \\
\text { and biogenesis, metal ion binding, zinc ion binding }\end{array}$ \\
\hline DNA methyltransferase 3A (Dnmt3a) & NM_153743 & $12 \mathrm{~A} 2-\mathrm{A} 3$ & $\begin{array}{l}\text { Adipose tissue, bonemarrow, amygdale, preoptic, cerebel- } \\
\text { lum, cerebral cortex, dorsal striatum, hippocampus, } \\
\text { hypotalamus, main olfactory epithelium, olfactory bulb, } \\
\text { spinal cord upper, spinal cord lower, substantia nigra, } \\
\text { embryo day 10.5, ovary, placenta, umbilical cord, uterus, } \\
\text { heart, lymphnode, skeletal muscle, vomeronasal organ, } \\
\text { pancreas, pituitary, snout epidermis, spleen, thymus, } \\
\text { thyroid, retina }\end{array}$ & $\begin{array}{l}\text { Required for genome wide de novo methylation and is } \\
\text { essential for development }\end{array}$ \\
\hline
\end{tabular}




\section{Gene name}

GenBank

Early growth response 1 (Egr1)

accession

Chr

Chromosomes

Predominant expression

Molecular/biological function

NM_007913 18 Adipose tissue, adrenal gland, amygdale, frontal cortex,

preoptic, cerebellum, cerebral cortex, dorsal root ganglia,

hippocampus, hypotalamus, olfactory bulb, spinal cord

lower, substancia nigra, ovary, heart, small intestine,

B220+B-cells, CD4+ Tcells, CD8+ Tcells, lung,

lymphnode, skeletal muscle, tongue, pituitary, digits,

epidermis, snout epidermis, stomach, thymus, trachea

Deoxyhypusine synthase (Dhps)

NM_201408

$8 \mathrm{C} 2$

Insulin degrading enzyme (Ide)

NM_031156

Interleukin 12a (IL12a)

NM_008351

3

Bonemarrow, amygdale, frontal cortex, preoptic, trigeminal, cerebellum, cerebral cortex, dorsal root ganglia, dorsal striatum, hippocampus, hypotalamus, olfactory bulb, substantia nigra, blastocysts, embryo day 10.5 , embryo day 6.5, embryo day 7.5, embryo day 8.5, embryo day 9.5, mammary gland, uterus, B220+B-cells, CD4+ Tcells, CD8+ Tcells, lymphnode, vomeronasal organ, thymus, kidney, retina

Adipose tissue, adrenal gland, main olfactory, embryo day 6.5, embryo day 7.5, embryo day 9.5, fertilized egg, ovary, prostate, uterus, oocyte, heart, CD8+ Tcells, skeletal

muscle, vomeronasal organ, salivary gland, tongue, thymus, trachea, bladder

cerebral cortex, dorsal striatum, olfactory bulb, spinal cord

upper, substantia nigra, embryo day 10.5, embryo day 6.5,

embryo day 7.5, embryo day 8.5, embryo day 9.5 , fertilized egg, B220+B-cells, CD8+ Tcells, lymphnode, skeletal muscle, spleen, thyroid

Helicase, mus308-like (Drosophila)

BC082601

Fertilized egg, oocyte

Nuclear receptor subfamily 3, group C, member $1(\mathrm{Nr} 3 \mathrm{c} 1)$

NM_008173 cerebellum, main olfactory epithelium, ovary, placenta,
Brown fat, Adipose tissue, frontal cortex, preoptic, umbilical cord, large intestine, B220+B-cells, CD4+

Tcells, CD8+ Tcells, lung, skeletal muscle, epidermis,
Transcriptional regulator

Catalyzes the NAD-dependent oxidative cleavage of spermidine

Can cleave insulin and tgf-alpha

Cytokine that can act as a growth factor for activated $\mathrm{T}$ and NK cells (by similarity)

ATP binding, DNA metabolism, helicase activity, hydrolase activity, RNA binding, single-stranded DNAdependent ATP-dependent DNA helicase activity Receptor for glucocorticoids (gc)

thymus, trachea, kidney 


\section{Determination of PGE in the thymus}

Promiscuous gene expression is currently identified on the basis of data from microarray analysis for the different mouse organs using combined information from the public database GNF Gene Expression Atlas (http://symatlas.gnf.org/SymAtlas) (Su et al. 2004). This data bank presents gene expression in more than 60 mouse tissues/organs as assessed by gene array analysis using Affymetrics microarrays. Data information include GenBank accession, chromosomal location and molecular/biological function of each gene analysed (Table I).

At present, we are considering only the promiscuous genes whose expression was significantly induced in the thymus (as displayed by the SAM algorithm) and detected in different organs or tissues, besides the thymus, and whose expression levels were greater than median in relation to all other organs which appear in the GNF Atlas.

\section{Emergence of PGE during thymus ontogeny}

The complexity of PGE depends on increases in ascending order from cTECs, to immature mTECs, to mature $\mathrm{CD} 80^{\mathrm{hi}}$ mTECs. These different gene pools are not complementary but additive, that is, there is no apparent association between the respective molecular/biological functions of the genes in parenchymal organs. The significance of PGE in the thymus is associated with central tolerance (Sospedra et al. 1998; Bruno et al. 2002, 2004) persisting during the entire exporting period of $\mathrm{T}$ cells from the thymus (Derbinski et al. 2001).

In fact, self-tolerance induction is dependent on developmentally regulated key processes, such as expression of TCR on the surface of lymphocytes allowing for TCR-MHC-peptide recognition, which enables the positive/negative selection of $\mathrm{T}$ cells in fetal thymus (Kyewski and Derbinski 2004).

Studies with freshly obtained fetal thymus allowed for the demarcation of the emergence of TCR beta $\mathrm{V}(\mathrm{D}) \mathrm{J}$ recombination during in vivo thymus ontogeny among different inbred mouse strains, contributing to revealing the effect of the genetic background on $\mathrm{T}$ cell development (Macedo et al. 1999; Espanhol et al. 2004; Cardoso et al. 2006).

The control of gene expression during the development of this organ has gained priority among several research teams, including our own group (Espanhol et al. 2004; Magalhães et al. 2005; Cardoso et al. 2006) with the objective of developing a clearer understanding the molecular mechanism of the central tolerance induction.

The cDNA microarray method has permitted the possibility of analysing thousands of genes at once and of performing a true dissection of this organ by means of transcript identification, characterizing virtually all the main cell types populating the thymus (Puthier et al. 2004).

In a recent study, using the cDNA microarray method, we identified the in vivo modulation of several cell-signaling genes, including those of the calcium cascade pathway, which is important for individual stages of $\mathrm{T}$ cell maturation and the control of anergy during murine thymus ontogeny (Puthier et al. 2004).

Using the same kind of analysis, our group recently showed the modulation of gene expression in murine fetal thymus organ cultures (FTOCs), at transcriptome scale and revealed an overlap between genes associated with TCR V(D)J recombination and DNA repair. We demonstrated that the association of FTOC cultures and cDNA microarray technology allows for sufficient accuracy to uncover the participation of essential genes implicated in thymus development (Cardoso et al. 2006)

Considering that the expression of TCR in the surface of maturing $\mathrm{T}$ cells is a key feature, allowing the recognition of MHC-peptide during positive/negative selection, we are currently employing cDNA microarrays to observe the extent of PGE when the TCR V beta gene (TRBV8.1) rearrangement emerges during the in vivo development of the thymus of Balbc, $\mathrm{C} 57 \mathrm{Bl} / 6$ and $(\mathrm{Balb}-\mathrm{c} \times \mathrm{c} 57 \mathrm{Bl} / 6) \mathrm{F}_{1}$ mouse strains.

Comparing thymus gestation time as a result of fetal age, it was possible to determine the onset of gene induction, representing 57 different parenchymal and 7 lymphoid organs whose coded proteins are considered to be parenchymal organ antigens, thus indicating the occurrence of PGE.

Thymus transcriptome profiling was assessed using glass slide cDNA microarrays containing 4500 IMAGE thymus target sequences hybridized with fluorescent $\mathrm{Cy} 3$ or $\mathrm{Cy} 5$ cDNA probes. PGE was identified on the basis of gene expression data for the different parenchymal organs.

To identify significant changes in the gene expression of fetal thymus when TRBV8.1 V(D)J recombination occurred compared to a reference pool, we used a scatter plot of the observed relative difference $d(\imath)$ vs. the expected relative difference $d_{\mathrm{E}}(\imath)$ as shown by the SAM program.

Most of the 4500 sequences tested presented $d(i) \cong d_{\mathrm{E}}(\imath)$, indicating that their expression pattern remained unaltered. However, some genes were significantly repressed (71 in Balb-c, 57 in C57Bl/6 and 17 genes in (Balb-c $\left.\times \mathrm{C} 57 \mathrm{Bl} / 6) \mathrm{F}_{1}\right)$ or induced (3 in $\mathrm{C} 57 \mathrm{Bl} / 6$ and 70 genes in (Balb-c $\left.\times \mathrm{C} 57 \mathrm{Bl} / 6) \mathrm{F}_{1}\right)$.

In this study, we defined only the induced genes as a manifestation of PGE (Table I). Moreover, 2 induced ESTs were found in $\mathrm{C} 57 \mathrm{Bl} / 6$ and 38 in (Balb$\mathrm{c} \times \mathrm{C} 57 \mathrm{Bl} / 6) \mathrm{F}_{1}$ but, due to their actual status of unknown function or organ representation, these sequences were not considered. This is evidence that the extent of PGE is greater than observed in this study. 


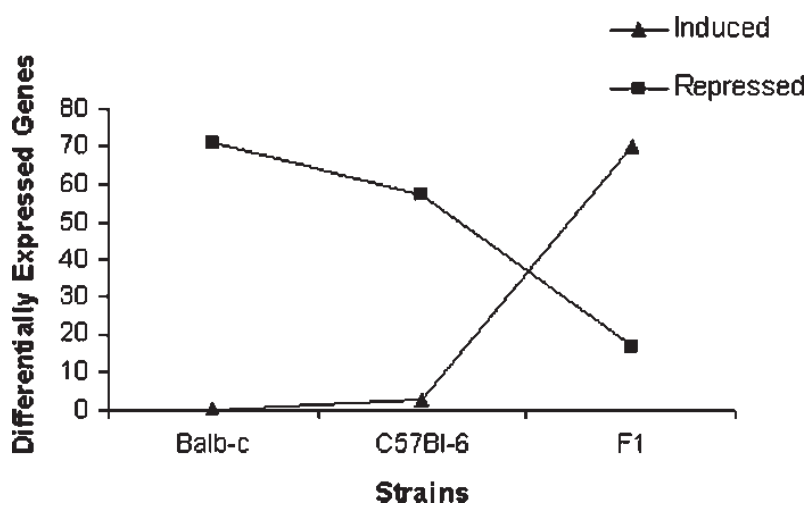

Figure 1. Number of significant induced or repressed genes in the fetal thymus during the emergence of TRBV8.1 recombination among inbred mouse strains. $\mathrm{F} 1=(\mathrm{Balb}-\mathrm{c} \times \mathrm{C} 57 \mathrm{Bl} / 6) \mathrm{F}_{1}$.

Interestingly, the microarray design and statistical stringency used in the SAM program allowed us to observe the manifestation of PGE at the onset of TRVB8.1 V(D)J recombination but this was observed only in the C57B1/6 strain and the (Balb$\mathrm{c} \times \mathrm{C} 57 \mathrm{Bl} / 6) \mathrm{F}_{1}$ hybrid. In the same developmental period, the Balb-c strain did not exhibit PGE, considering the statistical stringency we used in this study (Table I).

Figure 1 shows that among the strains studied, significant induction is inversely proportional to gene repression, strongly suggesting a role for the genetic background of strains in the control of PGE. Figure 2 illustrates that the reproductive and central nervous systems and stem cells/glands in $\mathrm{C} 57 \mathrm{Bl} / 6$ and the central nervous and reproductive systems and stem cells in (Balb-c $\times \mathrm{C} 57 \mathrm{Bl} / 6) \mathrm{F}_{1}$ are the predominant parenchymal organs most represented in the thymus in this phase of development, followed by the lymphoid system.

To our knowledge, these findings represent the first association study between the emergence of a TR gene $\mathrm{V}$ (D)J recombination (TRVB8.1) and occurrence of PGE among inbred mouse strains, with implications regarding the fine demarcation of key processes of selftolerance induction.

\section{Parenchymal organ representation in the thymus}

The 3 induced genes in $\mathrm{C} 57 \mathrm{Bl} / 6$ and 71 in (Balb$\mathrm{c} \times \mathrm{C} 57 \mathrm{Bl} / 6) \mathrm{F}_{1}$ identified as significantly induced at $14-15$ days p.c. were assigned to 57 parenchymal and 7 lymphoid organs according to their predominant expression, which were subgrouped in 17 systems.

\section{Chromosomal location of the differentially expressed genes}

The genomic distribution of the significantly modulated genes (repressed and induced), 71 in Balb-c, 60
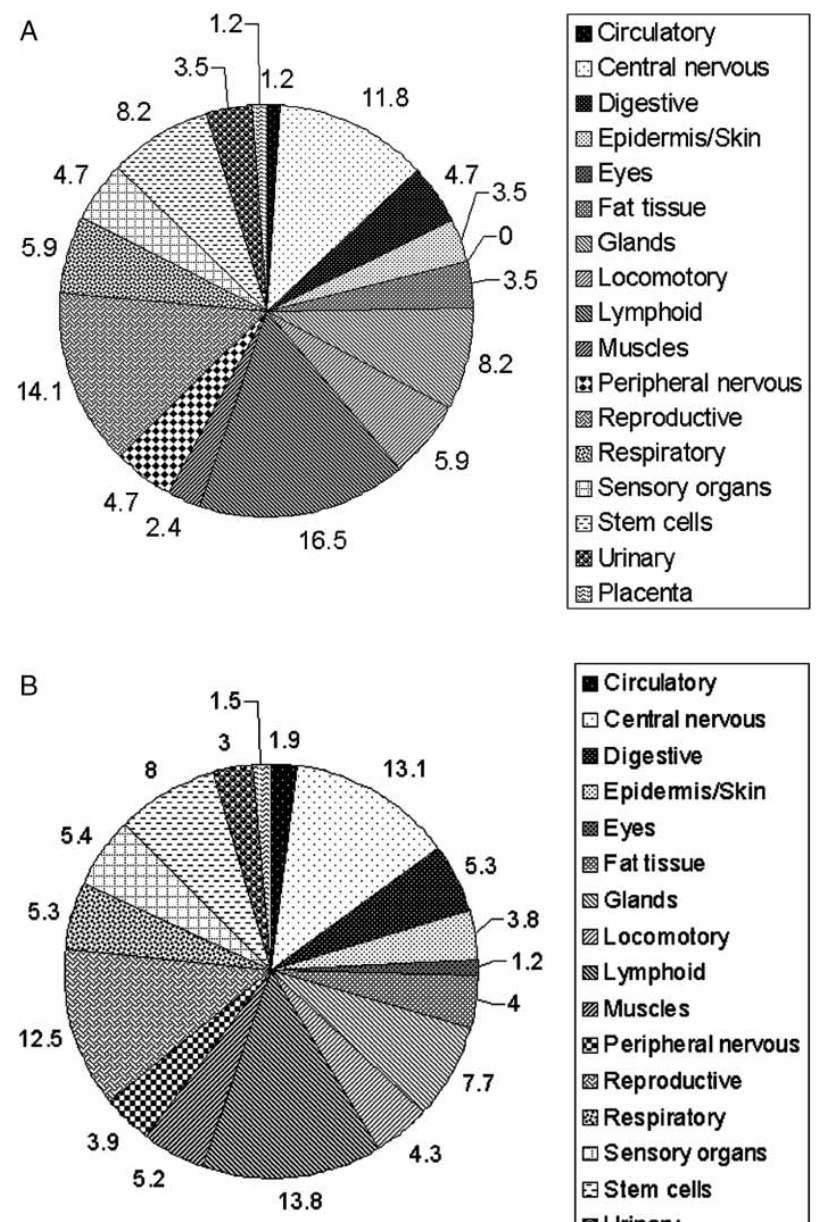

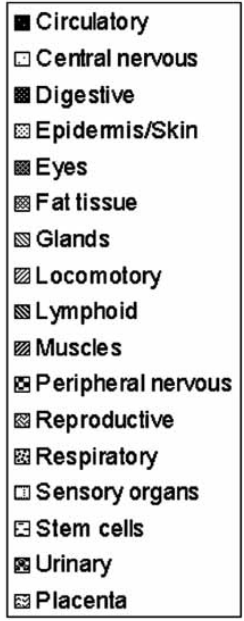

Figure 2. Representation of tissue/organ systems specific gene expression in the fetal thymus during the emergence of TRBV8.1 recombination. Analysis of 4500 sequences was performed using glass slide cDNA microarrays, whose significant induced genes were annotated characterizing the promiscuous expression, which allow self-representation of tissue specific antigens in the thymus. $2 \mathrm{~A}=\mathrm{C} 57 \mathrm{Bl} / 6,2 \mathrm{~B}=(\mathrm{Balb}-\mathrm{c} \times \mathrm{C} 57 \mathrm{Bl} / 6) \mathrm{F}_{1}$

in $\mathrm{C} 57 \mathrm{Bl} / 6$ and 87 in $(\mathrm{Balb}-\mathrm{c} \times \mathrm{C} 57 \mathrm{Bl} / 6) \mathrm{F}_{1}$, allowed for the organization of chromosomal clusters of coordinated expression.

Figure 3 shows the frequency distribution of the repressed and induced genes among chromosomes. All chromosomes, except Y, harbor differentially expressed genes, with slightly biased distribution on chromosomes 2, 5, 11, 13, 17 and 19 for the repressed genes in Balb-c, on chromosomes 2, 3, 6, 9 and 11 for the repressed and 11,13 and 17 for the induced in $\mathrm{C} 57 \mathrm{Bl} / 6$, on chromosomes 2, 7, 9, 13 and 15 for the repressed and on chromosomes $2,4,5,7,10$, 11,18 and 19 for the induced genes in the $\left(\right.$ Balb-c $\times$ C57B1/6) $\mathrm{F}_{1}$ hybrid.

\section{Discussion and perspective}

Self-tolerance induction should occur early, during the fetal development of the thymus, preventing 

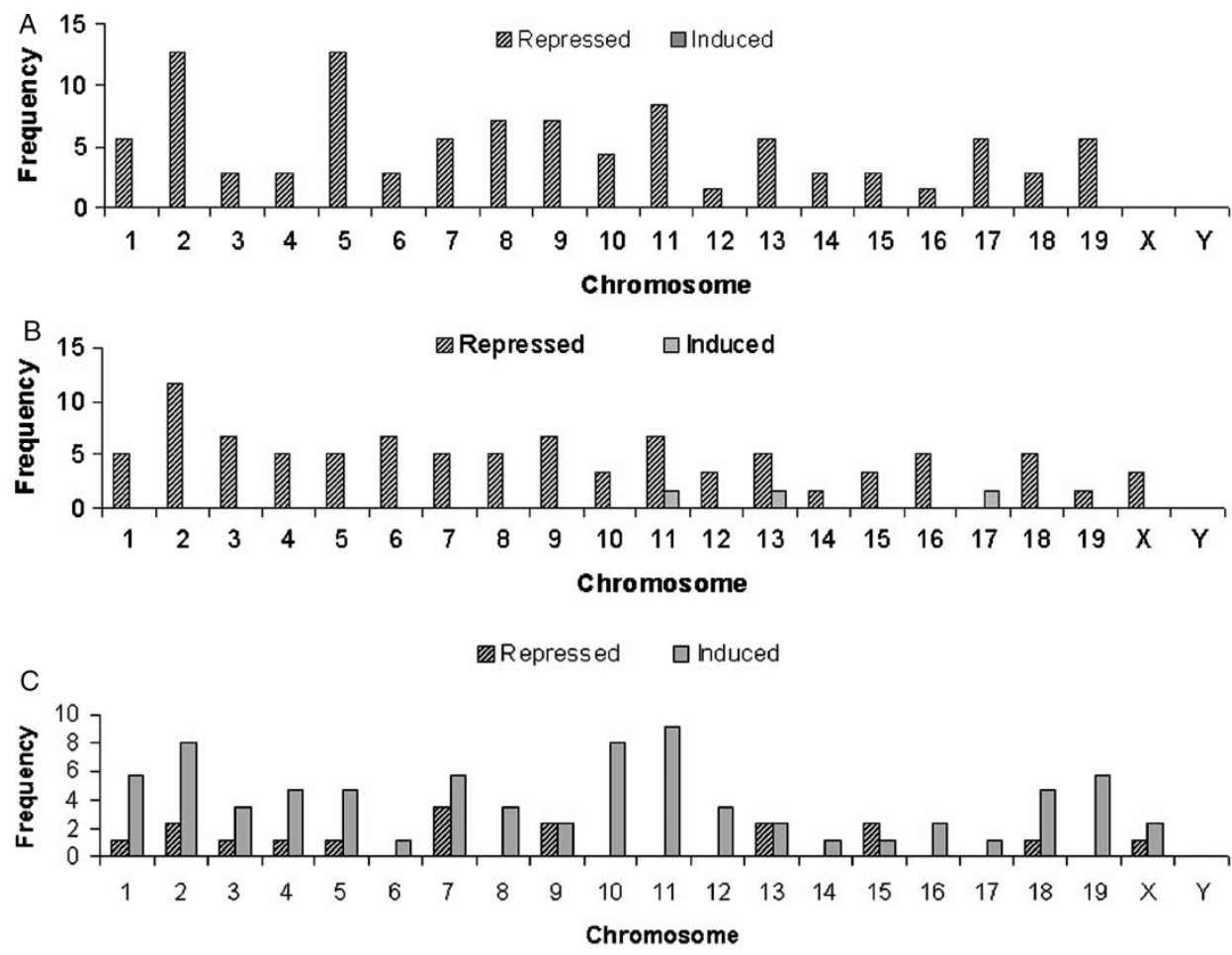

Figure 3. Chromosomal distribution of the repressed and induced genes in the fetal thymus during the emergence of TRBV8.1 recombination among inbred mouse strains. $3 \mathrm{~A}=$ Balb-c, $3 \mathrm{~B}=\mathrm{C} 57 \mathrm{Bl} / 6,3 \mathrm{C}=(\mathrm{Balb}-\mathrm{c} \times \mathrm{C} 57 \mathrm{Bl} / 6) \mathrm{F}_{1}$.

autoimmune pathological reactions. This phenomenon is dependent on the presentation of self-antigens to maturing $\mathrm{T}$ cells through TCR-MHC-peptide recognition (Sprent and Webb 1995; Hanahan 1998; Kishimoto and Sprent 2000). The assembling of functional TR genes, allowing for the expression of TCR on the surface of $T$ cells, is dependent on the temporal emergence of TR gene $\mathrm{V}(\mathrm{D}) \mathrm{J}$ recombination, during the fetal development of the thymus (Junta and Passos 1998; Macedo et al. 1999; Espanhol et al. 2004).

The extent of self-representation of most parenchymal tissues and organs is guaranteed by PGE in the thymus, a phenomenon that is exhibited by mTECs, is complex and involves $5-10 \%$ of all known genes in mice and humans. Accordingly, the complexity of PGE increases in ascending order, from cTECs to immature mTECs to mature CD $80^{\text {hi }}$ mTECs. These different gene pools are not complementary but additive, that is, there is no apparent association between the respective molecular/biological function of the genes in parenchymal organs. The significance of PGE in the thymus is associated with central tolerance of T cells (Sospedra et al. 1998; Bruno et al. 2002; Kyewski and Derbinski 2004). While PGE by mTECs was well characterized by the authors cited above, its time course during thymus ontogenetic development requires further exploration.

Molecular characterization of PGE during fetal development of different inbred mouse strains is a relevant approach in immunobiology, since this system can represent a potential tool in clarifying this question and in evaluating whether the different genetic backgrounds play a role in the control of PGE.

Moreover, knockout (KO) mice could reveal evidence for the role of specific genes in this process.

Evidence obtained by our team shows, for the first time, the occurrence of PGE in vivo during the fetal development of the thymus. To evaluate whether PGE in this model system is a developmental dependent phenomenon, we regarded the differential gene expression during ontogeny through the comparison of gestation days (p.c.), as the most informative in the delineation of the gene pool.

Moreover, we compared two different inbred mouse strains expressing different MHC haplotypes, Balb$\mathrm{c}=\mathrm{H}-2 \mathrm{~d}$ and $\mathrm{C} 57 \mathrm{Bl} / 6=\mathrm{H}-2 \mathrm{~K}$ and their hybrid $($ Balb-c $\times \mathrm{C} 57 \mathrm{Bl} / 6) \mathrm{F}_{1}$ demonstrating that PGE emerges on different days among the strains studied. These findings strongly suggest a role for the genetic background of these strains in the control of the emergence and extent of PGE.

Our results show that PGE occurs during thymus maturation; after TRBV8.1 gene $\mathrm{V}(\mathrm{D}) \mathrm{J}$ recombination in Balb-c and coinciding with TRBV8.1 V(D)J recombination in $\mathrm{C} 57 \mathrm{Bl} / 6$ and in (Balb$\mathrm{c} \times \mathrm{C} 57 \mathrm{~B} 1 / 6) \mathrm{F}_{1}$.

The early fetal thymus, by $13-15$ days p.c., is mainly composed of homogeneous double-negative (DN) $\mathrm{CD} 4^{-} \mathrm{CD} 8^{-} \mathrm{T}$ cell precursors. By day 18 p.c. this population gradually acquires the CD4 marker 
resembling the adult $\mathrm{CD} 4^{\text {low }}$ precursor (Shortman and Wu 1996).

These features allow for TCR-MHC-peptide recognition and enable the positive/negative selection of $\mathrm{T}$ cells in fetal thymus.

Our evidence for the occurrence of PGE in the late fetal thymus can be associated with the timing of the molecular events of $\mathrm{T}$ cell tolerance induction during ontogeny.

The data collected here were obtained by the cDNA microarray method, with the expression of the 4500 mouse mRNA sequences analyzed by the SAM algorithm (20). We found statistically significant gene modulation showing 71 repressed genes in Balb-c, 57 repressed and 3 induced genes in $\mathrm{C} 57 \mathrm{Bl} / 6$ and 17 repressed and 70 induced genes in $($ Balb-c $\times \mathrm{C} 57 \mathrm{Bl} / 6) \mathrm{F}_{1}$. Moreover, the significantly induced genes were indicative of emergence of PGE (Table I).

While the experiments were not conducted with cell-sorted purified mTECs, this caused no problems in the detection of differential TSA gene expression in the thymus. In order to bypass this potential difficulty, we used a cDNA microarray method, including a dedicated statistical algorithm for data analysis (SAM algorithm), which presented sufficient accuracy to distinguish and quantify TSA gene expression originating from thymic epithelial cells, especially mTECs (Gotter et al. 2004, Kyewski and Derbinski 2004; Derbinski et al. 2005).

In fact, cDNA microarray data mining has permitted the virtual dissection of the mouse thymus into its principal cellular components by means of the identification of the specific cellular transcripts (mRNAs) (Puthier et al. 2004). These observations demonstrate the feasibility of the use of whole thymus as starting material in PGE studies.

In agreement with previous observations (Derbinski et al. 1995) the molecular/biological function of promiscuously expressed genes found in our model system, showed no interrelationship (Table I).

Regarding the chromosomal localization of the repressed and induced genes, no important preferential distribution was identified. All chromosomes harbor promiscuously expressed genes with slightly biased distribution on chromosomes 2, 5, 10 and 11 among the repressed genes and on chromosomes 2, 10 and 11 among the induced genes. The exception was chromosome Yon which no repressed or induced gene was positioned considering the statistical stringency used in this study. (Figure 3).

This feature of random PGE distribution in the genome, strongly suggests an uncommon model of gene regulation found in the thymus that needs further study.

In this regard, certain urgent questions remain, like whether the chromatin scaffold in mTECs is so arranged to allow for promiscuous gene expression and whether the methylation pattern of mouse genome controls this phenomenon.

Finally, the use of the fetal thymus model system and cDNA microarray method, open up perspectives to determine the modulation and extent of PGE in autoimmune diseases, through the analysis of genetically compromised mouse strains.

During preparing this article, the Science magazine (Sciencexpress Report) published online the evidence for a functional second thymus in mice, located in the neck, whose observations were done and communicated by Dr Rodewald's group of the University of Ulm, Ulm, Germany (Terszowski et al. 2006). Once broadly recognized the existence of the second thymus, this observation also provide perspective for reevaluating the physiological relevance of extra-thymic $\mathrm{T}$ cell development, as stated the authors and evaluate the occurrence of PGE in this organ.

\section{Acknowledgements}

Our research group received financial support from the FAPESP (Fundação de Amparo à Pesquisa do Estado de São Paulo, Brasil) and the CNPq (Consellho Nacional de Desenvolvimento Científico e Tecnológico, Brasil). The 2NTB cDNA library used to prepare the microarrays was kindly ceded by $\mathrm{Dr}$ Catherine Nguyen of the INSERM (Institut National de la Santé et de la Recherche Médicale, ERM 206, Marseille, France).

\section{References}

Alferink J, Aigner S, Reibke R, Hämmerling GJ, Arnold B. 1999. Peripheral $\mathrm{T}$ cell tolerance: The contribution of permissive $\mathrm{T}$ cell migration into parenchymal tissues of the neonate. Immunol Rev 169:255-261.

Bruno R, Sabater L, Sospedra M, Ferrer-Francesch X, Escudero D, Martínez-Cáceres E, Pujol-Borrel R. 2002. Multiple sclerosis candidate autoantigens except myelin oligodendrocyte glycoprotein are transcribed in the human thymus. Eur J Immunol 32:2737-2747.

Bruno R, Sabater L, Tolosa E, Sospedra M, Ferrer-Francesch X, Coll J, Foz M, Melms A, Pujol-Borrell R. 2004. Different patterns of nicotinic acetylcholine receptor subunit transcription in human thymus. J Neuroimmunol 149:147-159.

Cardoso RS, Junta CM, Macedo C, Magalhães DAR, Silveira ELV, Paula MO, Marques MMC, Mello SS, Zarate-Blades CR, Nguyen C, Houlgatte R, Donadi EA, Sakamoto-Hojo ET, Passos GAS. 2006. Hybridization signatures of gammairradiated murine fetal thymus organ culture (FTOC) reveal modulation of genes associated with T-cell receptor V(D)J recombination and DNA repair. Mol Immunol 43:464-472.

Derbinski J, Schulte A, Kyewski B, Klein L. 2001. Promiscuous gene expression in medullary thymic epithelial cells mirrors the peripheral self. Nat Immunol 2:1032-1039.

Derbinski J, Gäbler J, Brors B, Tierling S, Jonnakuty S, Hergenhahn M, Peltonen L, Walter J, Kyewski B. 2005. Promiscuous gene expression in thymic epithelial cells is regulated at multiple levels. J Exp Med 202:33-45.

Ehrlich P, Morgenroth J. 1901. Ueber Hämolysine. Berl Klin Wochenschr 28:251-257. 
Espanhol AR, Cardoso RS, Junta CM, Victorero G, Loriod B, Nguyen C, Passos GAS. 2004. Large scale gene expression analysis of $\mathrm{CBA} / \mathrm{J}$ mouse strain fetal thymus using cDNA-array hybridizations. Mol Cell Biochem 206:65-68.

Gallegos A, Bevan MJ. 2006. Central tolerance: Good but imperfect. Immunol Rev 209:290-296.

Gotter J, Brors B, Hergenhahn M, Kyewski B. 2004. Medullary epithelial cells of the human thymus express a highly diverse selection of tissue-specific genes co-localized in chromosomal clusters. J Exp Med 199:155-166.

Hanahan D. 1998. Peripheral-antigen-expressing cells in thymic medulla: Factors in self-tolerance and autoimmunity. Curr Opin Immunol 10:656-662.

Jolicoeur C, Hanahan D, Smith KM. 1994. T-cell tolerance toward a transgenic beta-cell antigen and transcription of endogenous pancreatic genes in thymus. Proc Natl Acad Sci USA 91:6707-6711.

Junta CM, Passos GAS. 1998. Emergence of TCR $\alpha \beta$ V(D)J recombination and transcription during thymus ontogeny of inbred mouse strains. Mol Cell Biochem 187:67-72.

Kishimoto H, Sprent J. 2000. The thymus and negative selection. Immunol Res 21:315-323.

Klein L, Kyewski B. 2000. Self-antigen presentation by thymic stromal cells: A subtle division of labor. Curr Opin Immunol 12:179-186.

Kyewski B, Derbinski J. 2004. Self-representation in the thymus: An extended view. Nat Rev Immunol 4:688-698.

Kyewski B, Derbinski J, Gotter J, Klein L. 2002. Promiscuous gene expression and central T-cell tolerance: More than meets the eye. Trends Immunol 23:364-371.

Macedo C, Junta CM, Passos GAS. 1999. Onset of T-cell receptor $\mathrm{V} \beta 8.1$ and $\mathrm{D} \beta 2.1 \mathrm{~V}(\mathrm{D}) \mathrm{J}$ recombination during thymus development of inbred mouse strains. Immunol Lett 69:371-373.

Magalhães DA, Macedo C, Junta CM, Mello SS, Marques MM, Cardoso RS, Sakamoto-Hojo ET, Passos GAS. 2005. Hybridization signatures during thymus ontogeny reveals modulation of genes coding for T-cell signaling proteins. Mol Immunol 42:1043-1048.

Medzhitov R, Janeway CA. 1997. Innate immunity, the virtues of a monoclonal system recognition. Cell 91:295-298.
Nguyen C, Rocha D, Granjeaud S, Baldit M, Bernard K, Naquet P, Jordan BR. 1995. Differential gene expression in the murine thymus assayed by quantitative hybridization of arrayed cDNA clones. Genomics 29:207-215.

Puthier D, Joly F, Irla M, Saade M, Victorero G, Loriod B, Nguyen C. 2004. A general survey of thymocyte differentiation by transcriptional analysis of knockout mouse models. J Immunol :6109-6118.

Rugh R. 1968. The mouse. Its reproduction and development. 1st ed. Edina, MN, USA: Burgess Publishing Company.

Sakamoto-Hojo ET, Passos GAS. 2006. Hybridization signatures of gamma-irradiated murine fetal thymus organ culture (FTOC) reveal modulation of genes associated with T-cell receptor $\mathrm{V}(\mathrm{D}) \mathrm{J}$ recombination and DNA repair. Mol Immunol 43:464-472.

Schwartz RH, Mueller DL. 2003. In: Paul WE, editor. Fundamental immunology. 5th ed., Philadelphia: Lippincott Williams \& Wilkins. p 901-934.

Shortman K, Wu L. 1996. Early T lymphocyte progenitors. Annu Rev Immunol 14:29-47.

Sospedra M, Ferrer-Francesch X, Dominguez O, Juan M, Foz-Sala M, Pujol-Borrel R. 1998. Transcription of a broad range of selfantigens in human thymus suggests a role for central mechanisms in tolerance toward peripheral antigens. J Immunol 161:5918-5929.

Sprent J, Webb SR. 1995. Intrathymic and extrathymic clonal deletion of T-cells. Curr Opin Immunol 7:196-205.

Su AI, Wiltshire T, Batalov S, Lapp H, Ching KA, Block D, Zhang J, Soden R, Hayakawa M, Kreiman G, Cooke MP, Walker JR, Hogenesch JB. 2004. A gene atlas of the mouse and human protein-encoding transcriptomes. Proc Natl Acad Sci USA 101:6062-6067.

Terszowski G, Müller S, Bleul CC, Blum C, Schirmbeck R, Reimamm J, DuPasquier L, Amagai T, Boehm T, Rodewald HR. 2006. Evidence for a second thymus in mice. Science, (Sciencexpress, www.sciencexpress.org, 2 March 2006; 10.1126/science.1123497).

Tusher VG, Tibshirani R, Chu G. 2001. Significance analysis of microarrays applied to the ionizing radiation response. Proc Natl Acad Sci USA 98:5116-5121.

Walker LS, Abbas AK. 2002. The enemy within: Keeping self-reactive $\mathrm{T}$ cells at bay in the periphery. Nat Rev Immunol 2:11-19. 


\title{
Hybridization signatures of gamma-irradiated murine fetal thymus organ culture (FTOC) reveal modulation of genes associated with T-cell receptor $\mathrm{V}(\mathrm{D}) \mathrm{J}$ recombination and DNA repair
}

\author{
Renato S. Cardoso a , Cristina M. Junta ${ }^{\text {a }}$, Claudia Macedo a , Danielle A.R. Magalhães ${ }^{\text {a }}$, \\ Eduardo L.V. Silveira ${ }^{a}$, Marina O. Paula ${ }^{a}$, Márcia M.C. Marques ${ }^{a}$, Stephano S. Mello ${ }^{b}$, \\ Carlos R. Zárate-Bladés ${ }^{\mathrm{c}}$, Catherine Nguyen ${ }^{\mathrm{d}}$, Remi Houlgatte ${ }^{\mathrm{d}}$, Eduardo A. Donadi ${ }^{\mathrm{e}}$, \\ Elza T. Sakamoto-Hojo ${ }^{b}$, Geraldo A.S. Passos ${ }^{a}, \mathrm{f}, *$ \\ ${ }^{a}$ Molecular Immunogenetics Group, Department of Genetics, Faculty of Medicine, University of São Paulo (USP), 14040-900 Ribeirão Preto, SP, Brazil \\ ${ }^{\mathrm{b}}$ Laboratory of Cytogenetics and Mutagenesis, Department of Genetics, Faculty of Medicine, USP, 14040-900 Ribeirão Preto, SP, Brazil \\ ${ }^{c}$ Basic and Applied Immunology Program, Faculty of Medicine, USP, 14040-900 Ribeirão Preto, SP, Brazil \\ ${ }^{\mathrm{d}}$ Advanced Technologies for the Genome and Clinics (TAGC), INSERM Unit ERM 206, 13288 Marseille, France \\ ${ }^{\mathrm{e}}$ Department of Medicine, Faculty of Medicine, USP, 14040-900 Ribeirão Preto, SP, Brazil \\ ${ }^{\mathrm{f}}$ Discipline of Genetics (DMEF), Faculty of Dentistry, USP, 14040-900 Ribeirão Preto, SP, Brazil
}

Received 28 October 2004; accepted 4 March 2005

Available online 13 April 2005

\begin{abstract}
In this study, we observed the occurrence of TRBV8.1-DB2.1 V(D)J recombination in murine fetal thymus organ culture (FTOC), in which the thymic microenvironment is mimicked. Since ionizing radiation affects T-cell development, we irradiated FTOCs with gamma rays to evaluate the modulation of genes implicated in TRBV8.1-BD2.1 rearrangements. The nylon cDNA microarray method was employed to monitor the expression of 9216 genes, which were organized in coexpression clusters. Clustering analysis showed similar expression profiling of genes implicated in the V(D)J recombination and DNA double strand break (DSB) repair processes such as XRCC4, RAG-2, Artemis and DNAPK-cs, thus suggesting overlap between the two processes. The RUNX3 gene, whose coded protein binds to the enhancers of TR genes, was also modulated and the DNA cross-linking LR1 gene, which plays a role in the opening of hairpin DNA structures and whose expression pattern is similar to Artemis, may play a role in the control of V(D)J recombination. Furthermore, our data demonstrate that the FTOC model system and cDNA microarray method are useful tools to evidentiate genes that may play a role in both processes $\mathrm{V}(\mathrm{D}) \mathrm{J}$ recombination and DNA repair. (C) 2005 Elsevier Ltd. All rights reserved.
\end{abstract}

Keywords: FTOC; T-cell receptor beta; V(D)J recombination; DNA repair; cDNA microarray; Transcriptome profiling; Ionizing radiation

\section{Introduction}

The differentiation of thymocytes to mature T-cells occurs within the fetal thymus and all developmental stages are distinguishable by their expression of a combination of CD cell-surface markers. This is a highly modulated phenomenon whose central molecular machinery is formed by the recombinase complex (recombination activating genes,

\footnotetext{
* Corresponding author. Tel.: +55 16602 30 30; fax: +55 166330069

E-mail address: passos@rge.fmrp.usp.br (G.A.S. Passos).
}

RAG-1 and RAG-2) directly implicated in the V(D)J recombination of T-cell receptor (TRA, TRB, TRG and TRD) and immunoglobulin (Ig) gene segments (Lefranc and Lefranc, 2001).

The occurrence of the $\mathrm{V}(\mathrm{D}) \mathrm{J}$ reaction is important for triggering the maturation of T-cells and is also regulated by several other gene products such as interleukins (Muegge et al., 1993; Sollof et al., 1997; Fink and McMahan, 2000; Fugmann, 2002; Espanhol et al., 2003). Using the cDNA array method, we have previously found that during a fetal phase of the in vivo development of the murine thymus, when 
the TR gene rearrangements begin, several genes related to DNA synthesis, protein metabolism, oncogenes, transcription factors and signal transduction are modulated in concert (Espanhol et al., 2004; Magalhães et al., 2005).

Functional analysis of T-cell development has become possible after the introduction of techniques in which the thymic microenvironment is mimicked, such as fetal thymus organ culture (FTOC). This method is based on the use of early fetal thymus tissue, which is composed of homogeneous thymocyte population (double-negative cells), and on the possibility of testing the induction of alterations in gene expression during T-cell development caused by chemical and physical agents (DeLuca et al., 1995).

In the present study, we demonstrated the occurrence of the TRBV8.1-BD2.1 rearrangement in FTOCs, indicating the occurrence of T-cell maturation in vitro. Moreover, the FTOC transcriptome profiling was accessed using a set of six nylon cDNA microarrays containing a total of 9216 thymus IMAGE sequences.

Comparing time of thymus gestation as a result of age of fetuses and length of cultures, versus gamma-irradiated and unirradiated cultures, it was possible to found genes differentially expressed, several among them were considered to be novel candidates participating simultaneously in the control of T-cell receptor $\mathrm{V}(\mathrm{D}) \mathrm{J}$ recombination and DNA repair.

Each phase of thymus development in FTOCs exhibited a characteristic gene expression pattern involving genes of known functions, permitting the identification of those implicated in T-cell maturation, including the V(D)J recombination process.

Since in the both processes, DNA repair of damage caused by ionizing radiation and T-cell receptor $\mathrm{V}(\mathrm{D}) \mathrm{J}$ recombination occurs reparation of DNA double-strand breaks (DSBs) (Prise et al., 2001; Toki et al., 2003), we irradiated FTOCs with gamma rays to evaluate the effects on TRB V(D)J recombination and on modulation of genes implicated in these mechanisms.

Among the genes which were found to be differentially expressed, several were considered to be novel candidates participating simultaneously in the control of T-cell receptor $\mathrm{V}(\mathrm{D}) \mathrm{J}$ recombination and DNA repair.

\section{Material and methods}

\subsection{Fetal thymus organ culture, total RNA and genomic DNA preparations}

BALB-c mice were bred in an $0.45 \mu \mathrm{m}$ pore size air filtered isolator in our own breeding facility. To obtain timed pregnancies, mice were mated and the day when the vaginal plug was obtained at 7:00 am was considered to be day zero of gestation post coitum (pc). Pregnant mice were sacrificed by ether inhalation and the fetuses collected by surgery of the uterus. The pc age of fetuses was confirmed by the morpho- logical characteristics of each developmental phase (Rugh, 1968).

Thymi were removed from the fetuses under a stereomicroscope and cultured according to the organ culture technique described by DeLuca et al., (1995). The organs were dissected and cleaned from adjacent tissue and placed on the surface of Millipore filters $(0.45 \mu \mathrm{m}$ pore size $)$ pre-embedded with culture medium. These filters were supported on plastic grids in $2 \mathrm{ml}$ Dulbecco's modified Eagle's Medium/HAM F-10 culture medium (GIBCO, USA) supplemented with $20 \%$ heat inactivated fetal bovine serum (Biobrás, Brazil). The medium was also supplemented with $100 \mu \mathrm{g} / \mathrm{ml}$ streptomycin, $250 \mathrm{U} / \mathrm{ml}$ penicillin, $10 \mu \mathrm{g} / \mathrm{ml}$ gentamicin, $1 \mathrm{mM}$ sodium pyruvate, $20 \mu \mathrm{M}$ 2-mercaptoethanol and $3.4 \mathrm{~g} / \mathrm{L}$ sodium bicarbonate. The incubation time of the organ culture varied from 2 to 5 days at $37^{\circ} \mathrm{C}$ in a $5 \% \mathrm{CO}_{2}$ incubator.

Thymi were dissected from fetuses obtained at 13,14 and 15 days of gestation and cultured for two days, respectively, mimicking 15, 16 and 17 days of in vivo development. Thymi from 15 days pc fetuses were also cultured for 5 days, mimicking the 20th day of in vivo development, and in this case, the culture medium was changed on the 3rd day of incubation.

Immediately after culture preparation, some FTOCs were irradiated with $4 \mathrm{~Gy}$ of gamma rays from ${ }^{60} \mathrm{Co}$ source using a Gammatron S-80 apparatus (Siemens, Germany) at the dose of $0.53 \mathrm{~Gy} / \mathrm{min}$. Control cultures were sham irradiated.

In order to evaluate the viability of FTOCs before and after irradiation, three randomly selected thymus of each group was used for the single cell suspensions preparation which were separately stained with acridine orange $(100 \mu \mathrm{g} / \mathrm{ml})$ or with ethidium bromide $(100 \mu \mathrm{g} / \mathrm{ml})$ and analyzed on a Axiophot II fluorescence microscope (Carl Zeiss, Germany) in order to evaluate the frequency of apoptosis and necrosis, respectively.

Total RNA and genomic DNA were prepared from FTOCs using Trizol ${ }^{\circledR}$ reagent according to manufacturer instructions (Invitrogen, USA).

\subsection{Semiquantitative TRBV8.1-BD2.1 recombination assay}

T-cell maturation was monitored by detection of rearrangements between segments TRBV8.1 and BD2.1 during FTOC development using PCR as previously described (Muegge et al., 1993). The oligonucleotide primers were the BV8.1 forward primer (primer 1, CAGGCTGCAGTCACCCAAAGTCCAA), the BV8.1 reverse primer (primer 2, ACAGAAATATACAGCTGTCTGAGAA) and the BJ2.1 reverse primer (primer 3, TGAGTCGTGTTCCTGGTCCGAAGAA). The PCR mixture contained $35 \mathrm{mM}$ Tris, $\mathrm{pH}$ $8.3,50 \mathrm{mM} \mathrm{KCl}, 2.5 \mathrm{mM} \mathrm{MgCl} 2,100 \mu \mathrm{g} / \mathrm{ml}$ bovine serum albumin, nucleotide triphosphates (NTPs) $(2 \mu \mathrm{M}$ each), the primers $(0.5 \mu \mathrm{M}$ each) and $1 \mathrm{U}$ Taq polymerase (Amersham Biosciences, Buckinghamshire, UK), with a constant amount of genomic DNA $(1 \mu \mathrm{g})$ from each developmental stage in FTOC. The PCR program consisted of 30 cycles (1 min at 
$94{ }^{\circ} \mathrm{C}, 2.5 \mathrm{~min}$ at $54^{\circ} \mathrm{C}$ and $1.5 \mathrm{~min}$ at $70^{\circ} \mathrm{C}$, with a 7 -min extension period).

In order to make this PCR a semiquantitative method, we included in the mix an internal amplification control of the $\beta$-actin gene ( $\beta$-actin forward ATGGATGACGATATCGCT and $\beta$-actin reverse ATGAGGTAGTCTGTCA). The adequate number of PCR cycles to reach the log-phase amplification was determined in experiments with 25,30 and 35 PCR cycles. The signal generated by the 30 -cycle PCR was significantly lower than that generated by the 35-cycle PCR. This result demonstrates that at 30-cycle PCR, the amplification of the TRBV8.1-BD2.1 rearranged segment (and the beta-actin segment) was at log-phase and was adopted in this study (data not shown).

After cycling, $15 \mu \mathrm{l}$ of PCR products were resolved by $1.8 \%$ agarose gel electrophoresis and transferred (blotting) to a nylon Hybond $\mathrm{N}+$ membrane (Amersham Biosciences). The PCR products were identified by hybridization with 7-15 million cpm of each T-cell receptor beta (TRBV8.1) and $\beta$ actin ${ }^{32} \mathrm{P}$ radiolabeled probe.

Imaging plates and a phosphor imager apparatus $(\mathrm{Cy}-$ clone model, Packard Instruments, USA) were used to capture the hybridization signals and the OptiQuant ${ }^{\circledR}$ software (Packard) was used to quantify the signals with local background subtraction. The adequate level of image saturation was ensured by serial dilution of the positive control (data not shown).

For the data from V(D)J recombination experiments we applied $t$-test as statistical method of analysis and a $P$ value $<0.05$ was considered to be significant from three independent determinations.

\section{3. cDNA microarray method}

We used a set of six microarrays containing a total of 9216 cDNA sequences in the form of PCR products, spotted in duplicate on $2.5 \mathrm{~cm} \times 7.5 \mathrm{~cm}$ Hybond $\mathrm{N}+$ nylon membranes (Amersham Biosciences). The arrays were prepared in our laboratory using a Generation III Array Spotter (Amersham Biosciences-Molecular Dynamics, USA).

Mouse thymus expressed sequence tag (EST) cDNA clones were obtained from the Soares thymus 2NbMT normalized library, prepared from a C57B1/6J 4-week-old male thymus, and available from the I.M.A.G.E. Consortium (http://image.llnl.gov/image/html/iresources.shtml) and from the RZPD Deutsches Ressourcenzentrum für Genomforschung $\mathrm{GmbH}$ (www.rzpd.de).

The cDNA inserts were homogeneous in size (near $1 \mathrm{~kb}$ ) and cloned in three vectors ( $\mathrm{pT} 7 \mathrm{~T} 3 \mathrm{D}$, pBluescript and Lafmid) and were amplified on 384- or 96-well plates using vector-PCR amplification with the following primers, which recognize the three vectors: LBP 1S GTGGAATTGTGAGCGGATACC forward and LBP 1AS GCAAGGCGATTAAGTTGG reverse.

The membranes were first hybridized with the LBP 1 AS $\left[\gamma^{-}{ }^{33} \mathrm{P}\right] \mathrm{dCTP}-$ labeled oligonucleotide (vector hybridization).
Quantification of the obtained signals allowed the estimation of the amount of cDNA insert deposited in each spot. After stripping, the membranes were used for hybridization with cDNA complex probes (sample hybridization).

The characterization of each cDNA sequence was updated using the Eloge ${ }^{\circledR}$ (Ipsogen, France, www.ipsogen.fr) software, which runs on our local server and links each clone ID with the genome data banks GenBank (www.ncbi. nlm.nih.gov) and S.O.U.R.C.E. (http://genome-www5. stanford.edu/cgi-bin/source/sourceSearch), providing information such as DNA and protein sequences, biological and molecular functions and chromosomal location.

\subsection{Complex $c D N A$ probe preparation and hybridization}

In this study, we refer to the radioactive cDNA originating from the thymus RNA samples (FTOCs) as complex probe and to the PCR product originating from the clones and deposited on nylon microarrays as target.

The ${ }^{33} \mathrm{P}$-labeled cDNA complex probes were prepared by reverse transcription of $10 \mu \mathrm{g}$ of thymus total RNA using oligo $\mathrm{dT}_{12-18}$ as primer. One-hundred $\mu{ }^{33} \mathrm{P}$-cDNA complex probe containing 30-50 million cpm was hybridized with nylon microarrays as previously described (Nguyen et al., 1995; Bertucci et al., 2002; Verdeil et al., 2002).

\section{5. cDNA microarray image acquisition}

We used imaging plates and a phosphor imager apparatus (Packard model Cyclone) to capture the hybridization signals and the BZScan software (available from the authors at http://www.tagc.univ-mrs.fr) to quantify the signals with local background subtraction, whose spots were matched with a template grid.

The ratio between vector probe hybridization values and complex probe hybridization values for each spot was used as reference normalization value. We also employed total intensity normalization using the median expression value (Quackenbush, 2002).

\subsection{Hierarchical clustering}

We used a hierarchical clustering algorithm, comparing means of different genes whose standard deviation did not overlap, and whose objective was to compute a dendrogram that assembles all elements into a single tree. The software for this algorithm can be obtained from the authors (Eisen et al., 1998) at (http://rana.stanford.edu/clustering). Before clustering, the gene expression values were mediancentered and log transformed using the Pearson correlation distance metrics and average linkage for clustering organization from six independent determinations of each situation studied. 


\section{Results}

\subsection{Monitoring thymocyte maturation in FTOCs}

The detection of the TRBV8.1-BD2.1 rearranged DNA segment was evidence for thymocyte maturation in FTOCs. Using a semiquantitative PCR method, it was possible to detect significant amounts $(P<0.05)$ of amplification products for both the $\beta$-actin internal control and the TRBV8.1-BD2.1 segment (Fig. 1). The onset of $\mathrm{V}$ (D)J recombination occurred at the 14 day pc fetal thymi after 2 days in FTOC (these 2 days of incubation time correspond to the 16th day of gestation in vivo).

Gamma irradiation caused a 1.5-fold significant increase $(P<0.05)$ of the TRBV8.1-BD2.1 segment in 15 day pc fetal thymus incubated for five days in FTOC (corresponding to the 20th day pc in vivo); however, organ irradiation did not change the onset of recombination, which also occurred in irradiated 14 day pc fetal thymus (corresponding to the 16th day of gestation in vivo). This dose of gamma irradiation did not significantly changed cell viability ( $t$-test, $P<0.05)$ of FTOCs as evaluated by determination of frequency of apoptotic and necrotic cells (Table 1).

\subsection{Hierarquical clustering}

The hierarchical cluster analysis of the results obtained for a total of 9216 sequences by comparison between irradiated and non-irradiated FTOCs showed variability in the hybridization signatures of gene expression presented by different cultures. The dendrogram shows that this variability allowed the distinction of samples according to incubation time, as well as the distinction between control and irradiated FTOCs (Fig. 2).

It was possible to identify several clusters of repressed and induced genes. However, six of them which included
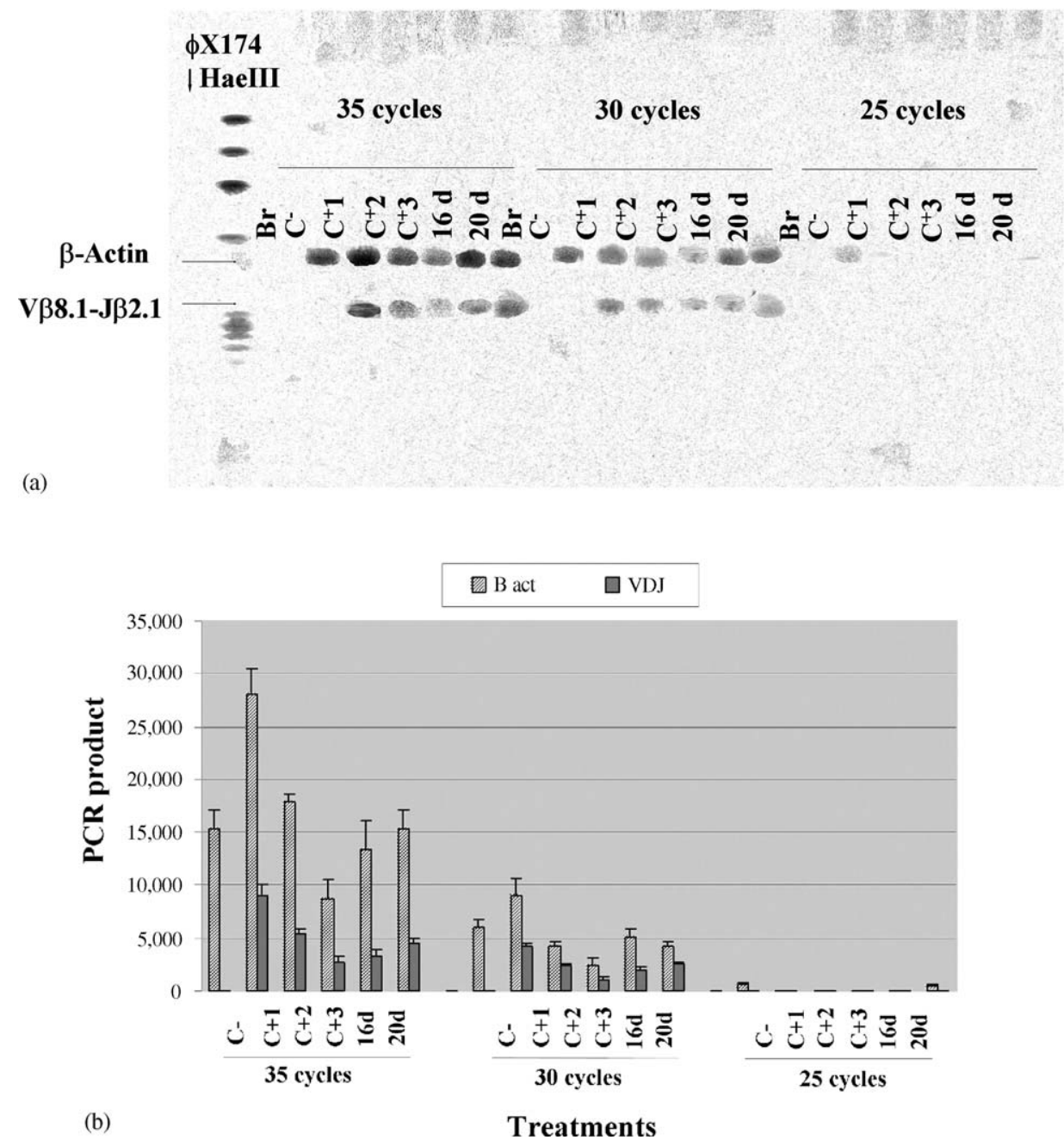

Fig. 1. Semiquantitative detection of V(D)J recombination between TRBV8.1 and BD2.1 during thymus development in control and gamma-irradiated FTOCs. Polymerase chain reactions were performed using TRBV8.1 and BD2.1 specific primers together with beta-actin primers as internal control in order to monitor reactions and normalize data. The 30-cycle PCR allowed amplification of the TRBV8.1-BD2.1 rearranged segment (and beta-actin segment) at log-phase. (A) Southern-blot of PCR products. (B) Quantification of hybridizations using a phosphor-imager. Arbitrary normalized values (on the basis of beta-actin values) expressed as digital light units (DLU) as displayed by the OptiQuant ${ }^{\circledR}$ software. 
Table 1

Frequency (\%) of apoptotic and necrotic cells in $4 \mathrm{~Gy}$ irradiated and control FTOCs

\begin{tabular}{llllll}
\hline & \multicolumn{2}{l}{ Apoptosis } & & \multicolumn{2}{l}{ Necrosis } \\
\cline { 2 - 3 } \cline { 6 - 6 } \cline { 6 - 6 } & Staging & & Staging & \\
\hline Control & 15 & $1.2 \pm 0.5$ & & 15 & $4.1 \pm 1.5$ \\
& 16 & $1.0 \pm 0.5$ & & 16 & $3.0 \pm 1.0$ \\
& 17 & $3.2 \pm 1.0$ & & 17 & $5.2 \pm 1.5$ \\
& 20 & $2.0 \pm 1.0$ & 20 & $2.7 \pm 1.0$ \\
Irradiated & 15 & $1.8 \pm 1.0$ & & 15 & $4.1 \pm 0.5$ \\
& 16 & $1.9 \pm 1.0$ & & 16 & $4.2 \pm 1.0$ \\
& 17 & $3.0 \pm 0.5$ & & 17 & $2.3 \pm 0.5$ \\
& 20 & $2.1 \pm 1.0$ & 20 & $5.8 \pm 1.5$ \\
\hline
\end{tabular}

Mean and standard deviation of three independent determinations. Data analyzed by $t$-test $(P<0.05)$.

Staging corresponds to development of fetal thymus in culture; 15 FTOC $=13$ day gestation thymus plus two days in FTOC.

genes implicated in cell cycle control, DNA repair, T-cell differentiation and $\mathrm{V}(\mathrm{D}) \mathrm{J}$ recombination were selected for discussion. The complete color heat-map indicating the six gene clusters is available online at (www.rge.fmrp. up.br/passos/FTOCcluster/9216).

Among the genes differentially expressed, we selected 42 to discuss from six clusters whose functions are associated with cell cycle control, transcription factors, immune regulation, T-cell V(D)J recombination and DNA repair (Table 2).

\section{Discussion}

\subsection{T-cell receptor and TRBV8.1 rearrangement occurs in vitro in FTOC}

The IL-7 is a cofactor associated with modulation of V(D)J recombination of TCR genes (Muegge et al., 1993; Sollof et al., 1997).

In this study, we described for the first time the occurrence of TRBV8.1-BD2.1 V(D)J recombination in vitro in FTOC.

The onset of TRBV8.1-BD2.1 V(D)J recombination in vitro mimicked the thymus gestation in vivo, demonstrating that this model system is similar to the in vivo development of

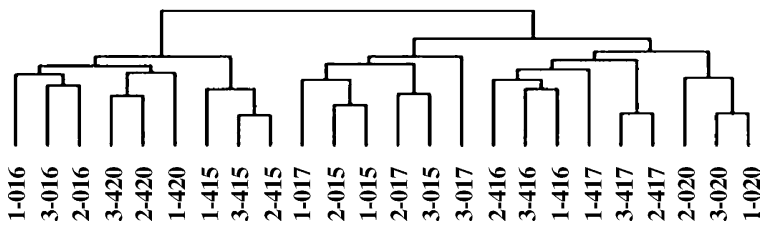

Fig. 2. Clustering RNA (cDNA) samples and 9216 genes of each developmental phase of control and gamma-irradiated FTOCs. The hierarchical clustering algorithm compared means of the different genes and RNA (cDNA) samples whose standard deviations did not overlapped computing the dendrogram that assembled all elements into a tree. Complete color heat-map indicating the repressed, induced and unmodulated genes among all situation studied is available online at (www.rge.fmrp.usp.br/passos/ FTOC/cluster9216). the thymus in inbred mouse strains, as previously described by our group (Espanhol et al., 2003; Macedo et al., 1999).

On the basis of a variety of criteria, FTOC reproduces the normal thymic development; however, the results can be influenced by the length of culture, and mouse strain and age (DeLuca et al., 1995).

In addition, it was shown that there are differences in temporal rearrangements at the TRBV locus, including the TRBV8.1 segment, among BALB-c, C57B1/6 and CBA/J inbred mouse strains, probably due to the different genetic backgrounds of the different strains (Espanhol et al., 2003; Macedo et al., 1999; Junta and Passos, 1998).

For this reason, the fetuses used in this study were obtained within the age range of 13-15 days of gestation pc, which permitted comparisons with the data obtained in vivo with the BALB-c strain.

\subsection{Hierarchical clustering}

The expression patterns disclosed several clusters of coexpressed genes, six of which (clusters 1-6) were selected for discussion on the basis of the biological functions of the most relevant genes investigated in this study.

Cluster 1 (correlation $=0.81$ ) harbors genes which were induced in irradiated cultures. This cluster displayed genes involved in cell cycle/cell division and DNA repair. Among them, we pinpointed MYB (myeloblastosis oncogene, accession no. NM010848, chromosome 10), which has a role in transcriptional activation and in the control of proliferation and differentiation of hematopoietic progenitor cells, and Kirsten rat sarcoma oncogene 2 (KRAS2, accession no. NM021284, chromosome 6). This oncogene belongs to the small GTPase superfamily (ras family), whose proteins bind to GDP/GTP and possess intrinsic GTPase activity. Its biological function is associated with control of the cell cycle. The induction of these oncogenes suggests triggering cell division by irradiation in FTOCs.

Interestingly, the cell division cycle 42 homolog $S$. cerevisiae gene (CDC42, accession no. NM009861, chromosome 4) which plays a role in GTPase-mediated signal transduction and participates in cytokinesis, presented an expression profile similar to that of the KRAS2 oncogene, suggesting that GTPase activity seems to be required after exposure to ionizing radiation.

The X-ray repair complementing defective repair in Chinese hamster cells 5 gene (Ku80) (XRCC5, accession no. NM009533, chromosome 1) participates in the mechanism of DNA double-strand break repair (DSB repair) via NHEJ. The induction of the XRCC5 gene suggests that NHEJ may constitute an important process of DNA repair in irradiated FTOCs.

Cluster 2 (correlation $=0.71$ ) encompasses genes involved in the regulation of transcription in T-cells such as signal transducer and activator of transcription 4 gene (STAT4, accession no. NM011487, chromosome 1), whose activities are associated with a transcription factor and 
Table 2

Genes differentially expressed (induced) in gamma-irradiated compared to control FTOCs as displayed by the Cluster and TreeView program

\begin{tabular}{|c|c|c|c|c|}
\hline Cluster & Gene name & Accession no. & Chromosome & Function \\
\hline \multirow[t]{4}{*}{1} & Myeloblastosis oncogene & NM10848 & 10 & Oncogene \\
\hline & Kirsten rat sarcoma oncogene 2 & NM021284 & 6 & Oncogene \\
\hline & Cell division cycle 42 & NM009861 & 4 & GTPase-signal transduction \\
\hline & $\mathrm{Ku} 80, \mathrm{X}$-ray repair, XRCC5 & NM009533 & 1 & DSB repair \\
\hline \multirow[t]{3}{*}{2} & Signal transducer activation of transcription & NM011487 & 1 & Transcription factor \\
\hline & Neuroprotective protein gene & AK129214 & $2 \mathrm{H} 3$ & Transcription factor \\
\hline & Nuclear factor of activated T-cells & AK048610 & 18 & Induction of cytokines \\
\hline \multirow[t]{9}{*}{3} & Transcription elongation factor 1 & AK048564 & $1 \mathrm{H} 2$ & RNA pol II transcription \\
\hline & Transcription elongation factor 3 & AJ223472 & 4D3 & RNA pol II transcription \\
\hline & Runt-related transcription factor 3 & AK053910 & 4 & Enhancer binding protein \\
\hline & Thyroid autoantigen $\mathrm{Ku} 70$ & BC051085 & 15 & DSB repair \\
\hline & Janus kinase 3 & L40172 & 8 & IL2/IL4 signaling \\
\hline & Interleukin receptor IL-11TRA2 & X98519 & 4 & Immune response/V(D)J recombination \\
\hline & Interleukin receptor IL-7R & NM008372 & 15 & TCR V(D)J recombination \\
\hline & Tumor necrosis factor, member7 & L24495 & 6 & Survival of activated T-cells \\
\hline & Granzyme A & M13226 & 13 & Targeting cell lysis \\
\hline \multirow[t]{5}{*}{4} & Fibroblast growth factor receptor 1 & ВC010200 & 8 & Embriogenesis \\
\hline & Vascular cell adhesion molecule 1 & AK089320 & 3 & Cell adhesion \\
\hline & Retinoblastome binding protein 7 & ВC003785 & XF4 & Negative regulation of transcription \\
\hline & SRY-box-SOX-4 & AK028989 & 13 & Binding to T-cell enhancer \\
\hline & Artemis protein & AK052369 & 2A1 & TCR V(D)J recombination \\
\hline \multirow[t]{7}{*}{5} & Mitogen activated protein kinase 7 & ВC070467 & 8A1.1 & Activation of Jun kinases \\
\hline & Insulin-like growth factor binding protein 7 & AB012886 & $5 \mathrm{D}$ & Regulation of cell growth \\
\hline & A-disintegrin and metalloprotease domain 8 & $\mathrm{BC} 025584$ & 7F3-F5 & Extravasion of leukocytes \\
\hline & Nuclear transcription factor Y-gamma & $\mathrm{BC} 053723$ & 4 & Transcription factor \\
\hline & Tripartite motif protein 28 & NM011588 & 7A1 & Transcription factor \\
\hline & Protease, serine, 16 (thymus) & AK088019 & 13 & Protease, T-cell development \\
\hline & Calpain 8 & NM130890 & $1 \mathrm{H} 5$ & Endopeptidase \\
\hline \multirow[t]{14}{*}{6} & $\mathrm{X}$-ray repair, XRCC4 & AK038105 & $13 \mathrm{C} 3$ & DSB repair \\
\hline & Heat shock protein 1-like & D85732 & 17 & Cooperation with chaperones \\
\hline & $\mathrm{XPC}$, xeroderma pigmentozum $\mathrm{C}$ & AK028595 & $6 \mathrm{D}$ & DNA excision repair (NER) \\
\hline & Interleukin IL-1B & NM008361 & 2 & Immune response \\
\hline & Interleukin IL-2 & X01772 & 3 & Immune response \\
\hline & Interleukin IL-6 & AK089780 & 5 & Immune response \\
\hline & Interleukin Il-7 & AK041403 & 3 & Immune response/ $\mathrm{V}(\mathrm{D}) \mathrm{J}$ recombination \\
\hline & Lymphotoxin A & NM10735 & 17 & Cytotoxic for tumor cells \\
\hline & Cyclin D3 & AK046638 & 17 & Protein kinase \\
\hline & EGR1, early growth response 1 & M22326 & 18 & Transcriptional regulator \\
\hline & RAG-2, recombination activator gene 2 & AK040375 & 2 & $\mathrm{~V}(\mathrm{D}) \mathrm{J}$ recombination \\
\hline & DNA-activated protein kinase & AK088981 & 16 & DSB repair and $V(D) J$ recombination \\
\hline & MMTV endogenous retrovirus & B4515481 & 19 & Superantigen \\
\hline & DNA cross-link LR1 & ВC011094 & $3 F 2.2$ & Nucleotide excision repair \\
\hline
\end{tabular}

a cytokine- and chemokine-mediated signaling pathway. Activity-dependent neuroprotective protein gene (ADNP, accession no. AK129214, chromosome 2H3) encodes a DNAbinding protein with transcription factor activity and nuclear factor of activated T-cells, cytoplasmic 1 gene (NFATC1, accession no. AK048610, chromosome 18) plays a role in the inducible expression of cytokine genes in T-cells, especially, in the induction of the IL-2 or IL-4 gene transcription.

The expression patterns of these genes in non-irradiated FTOCs suggest a tendency of induction at the early stages and repression at the late stages.

Cluster 3 (correlation $=0.71$ ) also encompasses genes involved in the regulation of transcription such as TCEA1 and TCEA3 (transcription elongation factor gene 1, accession no. AK048564, chromosome 1A2 and gene 3, accession no. AJ223472, chromosome 4D3), necessary for efficient RNA polymerase II transcription elongation past template-encoded arresting sites. Cleavage of the nascent transcript by S-II allows the resumption of elongation from the new $3^{\prime}$ terminus. The Runt-related transcription factor 3 gene (RUNX3 gene, accession no. AK053910, chromosome 4) codes for a protein that binds to the enhancers of T-cell receptor genes. As enhancers of TRs play a role in the control of gene rearrangements (Hempel et al., 1998), RUNX3 could participate in the control of TR V(D)J recombination.

G22P1 (Ku70) (thyroid autoantigen gene, accession no. BC051085, chromosome 15) plays a role in DSB repair via nonhomologous end-joining. Ku70/80 heterodimer is the 
DNA-binding subunit of DNA-PK, an important component of the repair of DSB via NHEJ (Lees-Miller and Meek, 2003).

Absence of Ku70 leads to hypersensitivity to ionizing radiation. Janus kinase 3 gene (JAK3, accession no. L40172, chromosome 8) codes for a tyrosine kinase of the nonreceptor type involved in the IL-2 and IL-4 signaling pathway. This gene belongs to the Tyr family of protein kinases and is implicated in lymph gland development. The interleukin receptor genes IL-11RA2 (accession no. X98519, chromosome 4) and IL-7R (accession no. NM008372, chromosome 15) are also present in cluster 3 and may later be associated with IL-7 signaling, which plays a role in the $\mathrm{V}(\mathrm{D}) \mathrm{J}$ recombination of TRs (Muegge et al., 1993; Sollof et al., 1997).

In addition, we observed genes associated with apoptosis such as tumor necrosis factor receptor superfamily, member 7 gene (TNFRSF7, accession no. L24495, chromosome 6) and GZMA (granzyme A gene, accession no. M13226, chromosome 13). TNFRSF7 encodes a receptor for tnfsf7/cd27l, possibly playing a role in survival of activated T-cells, while GZMA codes for a granzyme A precursor, an enzyme necessary for targeting cell lysis in cell-mediated immune responses.

Therefore, the induction of several genes in cluster 3 suggests the occurrence of T-cell differentiation following the irradiation stimulus in irradiated FTOCs.

Cluster 4 (correlation $=0.81$ ) contains genes with induced expression in irradiated FTOCs similar to cluster 3. Among the modulated genes, two may play a role in thymus morphogenesis in FTOC, the fibroblast growth factor receptor 1 gene (FGFR1, accession no. BC010200, chromosome 8) which may be essential for generation of mesodermal and endodermal layers and invaginations of various types of cells, and vascular cell adhesion molecule 1 gene (VCAM1, accession no. AK085320, chromosome 3) which is important in cell-cell recognition and appears to function in leukocyte-endothelial cell adhesion.

Two genes implicated in the control of transcription such as retinoblastoma binding protein 7 gene (RBBP7, accession no. BC003785 chromosome XF4) which plays a role in the negative regulation of transcription from the polymerase II promoter and SRY-box containing gene 4 (SOX4, accession no. AK028989, chromosome 13) which codes for a transcriptional activator that binds with high affinity to the T-cell enhancer $5^{\prime}$-AACAAAG-3' motif, may be associated with the control of V(D)J recombinations in FTOCs, in concert with the Artemis gene accession no. AK052369, chromosome $2 \mathrm{~A} 1$, which is directly associated with T-cell receptor gene rearrangements since these genes were included in the same cluster.

Cluster 5 (correlation $=0.78$ ) harbors genes, which were induced in irradiated FTOCs. Among these genes, we observed those associated with cell proliferation such as mitogen activated protein kinase 7 gene (MAP2K7, accession no. BC070467, chromosome 8A1.1) which has dual kinase activities involving the activation of jun kinases mapk8 (jnk1) and mapk9 (jnk2); as well as insulin-like growth factor binding protein 7 gene (IGFBP7, accession no. AB012886, chromosome 5D) that plays a role in the regulation of cell growth.

A gene associated with cell organization and biogenesis, A-disintegrin and metalloprotease domain 8 gene (ADAM8, accession no. BC025584, chromosome 7F3-F5), which is possibly involved in extravasation of leukocytes, was induced. As mature T-cells migrate from the thymus to the periphery, this gene could be implicated in such process.

Transcription factors such as nuclear transcription factorY gamma gene (NFYC, accession no. BC053723, chromosome 4), 3FP62 (tripartite motif protein 28 gene) (TRIM 28, accession no. NM011588 chromosome 7A1) form a complex with a krab-domain transcription factor and increase the efficiency of krab-mediated repression by recruiting setdb1 to histone $\mathrm{H} 3$ (by similarity).

We also observed induction of those genes implicated in protein metabolism such as PRSS16 [protease, serine, 16 (thymus) gene, accession no. AK088019, chromosome 13] which codes for a protease that may play a role in T-cell development and is specifically expressed in the developing thymus, and calpain 8 gene (CAP8, accession no. NM130890, chromosome 1H5) that codes for a cysteine-type endopeptidase and whose enzyme is involved in proteolysis and peptidolysis.

Cluster 6 (correlation $=0.77$ ) is formed by genes whose functions are directly related to the response to DNA damage stimulus such as X-ray repair complementing defective repair in Chinese hamster cells 4 gene (XRCC4, accession no. AK038105, chromosome 13C3) involved in DSB repair and heat shock protein 1-like gene (HSC70T, accession no. D85732, chromosome 17) whose coded protein in cooperation with other chaperones, for example HSP70, stabilizes pre-existing proteins against aggregation and mediates the folding of newly translated polypeptides in the cytosol, as well as within organelles. These chaperones participate in the recognition of non-native conformations of proteins. Another gene present in the cluster 6 was xeroderma pigmentosum, complementation group C gene (XPC, accession no. AK028595, chromosome 6D), which encodes a DNA repair protein, which is involved in DNA excision repair (NER) and may play a role in DNA damage recognition. XPC seems to recognize DNA helix distortions (Gontijo et al., 2003) and is responsible by opening the DNA helix in response to DNA damage (Tapias et al., 2004).

Moreover, as the DNA repair XPC protein may alter chromatin structure, it is plausible that its action could facilitate the accessibility of the V(D)J machinery to the TR locus.

We also found genes directly associated with immune response/activation and with the $\mathrm{V}(\mathrm{D}) \mathrm{J}$ recombination process. There are four interleukin genes, IL-1B, accession no. NM008361, chromosome 2; IL-2, accession no. X01772, chromosome 3; IL-6, accession no. AK089780, chromosome 5 and IL-7, accession no. AK041403, chromosome 3. The IL-7 is a cofactor associated with modulation of V(D)J 
recombination of TRB8.1 [2,3]. The lymphotoxin A gene, accession no. NM010735, chromosome 17, codes for the tumor necrosis factor produced by lymphocytes. This protein is cytotoxic for a wide range of tumor cells in vitro and in vivo.

Two genes in cluster 6 are implicated in immune cell activation, cyclin D3 gene (CCND3, accession no. AK046638, chromosome 17) codes for a cdk6 protein kinase essential for the control of the cell cycle at the G1/S transition and early growth response 1 gene (EGR1, accession no. M22326, chromosome 18) codes for a transcriptional regulator (early growth response protein 1) that activates the transcription of target genes whose products are required for mitogenesis and differentiation.

Finally, we found genes in this cluster closely implicated in the $\mathrm{V}(\mathrm{D}) \mathrm{J}$ recombination mechanism of T-cell receptor genes and immunoglobulins (Ig). The recombination activating gene 2 (RAG-2, accession no. AK040375, chromosome 2) codes for recombinase 2 , a component of the rag enzymatic complex (rag complex formed by rag- 1 and rag- 2 recombinases). This complex recognize and binds to the recombination signal sequences (RSSs) at the unrearranged TR or Ig loci, consisting of conserved heptamer and nonamer motifs separated by a spacer region of 12 or $23 \mathrm{bp}$.

$\mathrm{V}(\mathrm{D}) \mathrm{J}$ recombination results in a precise head-to-head ligation of two signal sequences in a joint signal, which may contain additions or deletions of a few bp. The reaction is initiated by the formation of DSB, which is resolved by the DNA repair machinery, followed by an exonuclease and/or by terminal deoxynucleotidyl transferase (TdT) before formation of a coding joint.

Mice that do not express RAG-1 or RAG-2 genes are unable to form DSB and there is evidence that DNA DSB repair and $\mathrm{V}(\mathrm{D}) \mathrm{J}$ recombination share a partially common mechanism (Schlissel et al., 1993; Chaudhuri and Alt, 2004; Jeggo and Concannon, 2001).

DNA-activated protein kinase gene (DNA-PK $\mathrm{Cs}_{\mathrm{cs}}$, accession no. AK088981, chromosome 16), also present in cluster 6 , codes for a large polypeptide DNA-dependent protein kinase catalytic subunit and its kinase activity is involved in DNA NHEJ required for DSB repair and V(D)J recombination. DNA-PK $\mathrm{cs}_{\mathrm{cs}}$ forms a complex with two subunits of the heterodimeric Ku protein $(\mathrm{Ku} 70$ and $\mathrm{Ku} 80)$ and must be bound to DNA to express its catalytic properties; cells that lack DNA-PK $\mathrm{cs}_{\mathrm{cs}}$ are radiosensitive and defective in DNA repair, while DNA-PK $\mathrm{Cs}_{\mathrm{cs}}$ null mice are viable but immunodeficient, due to inability to complete $\mathrm{V}(\mathrm{D}) \mathrm{J}$ recombination (Lees-Miller and Meek, 2003; Pastwa and Blasiak, 2003).

The assembly of the DNA-PK $\mathrm{Cs}_{\mathrm{cs}}$ complex to DNA ends is required for NHEJ binding step. Interestingly, the XRCC4 repair gene was also observed in cluster 6 , and the product of this gene was found to interact with DNA ligase IV stimulating the ligase activity, in order to complete the NHEJ mechanism and probably the $\mathrm{V}(\mathrm{D}) \mathrm{J}$ recombination process (Lees-Miller and Meek, 2003; Grawunder et al., 1997).
Interestingly, the MMTV endogenous retrovirus (accession no. BU515481, chromosome 19) is also present in this cluster and displayed overexpression in irradiated FTOCs. We have previously shown an association between the expression of MMTV and the parallel reduction of the TRBV8.1 rearranged segment in vivo during the thymus ontogeny of the CBA/J strain (Espanhol et al., 2003).

Finally, the DNA cross-link LR1 gene (DNA cross-link repair 1B, accession no. BC011094, chromosome 3F2.2), which codes for a protein involved in nucleotide excision repair, was induced in irradiated cultures. The deduced amino acid sequence of its coded protein was about $30 \%$ similar to that of the Artemis protein (Moshous et al., 2001) and its expression pattern was similar to that of genes implicated in $\mathrm{V}(\mathrm{D}) \mathrm{J}$ recombination, suggesting a possible role for this gene in this process.

In conclusion, our results showed for the first time that the FTOC model system reproduces the in vivo development of the thymus regarding TRBV8.1-BD2.1 V(D)J recombination.

Ionizing radiation, a potent physical agent capable of inducing DNA DSB, did not change the onset of recombination but increased the amount of the TRBV8.1-BD2.1 rearranged segment, suggesting a modulation of genes involved in such process.

The hybridization signatures obtained with cDNA microarrays permitted the identification of genes modulated during gamma irradiation of FTOCs. Among them, we found some genes related to the $\mathrm{V}(\mathrm{D}) \mathrm{J}$ recombination mechanism and we were able to pinpoint the DNA cross-link LR1 gene (DNA cross-link repair 1B) whose deduced protein sequence is similar to that of the Artemis protein, and the RUNX3 and SOX 4 genes whose coded proteins bind to the enhancers of $\mathrm{T}$-cell receptor genes.

The present data obtained by application of the cDNA microarray method indicated several genes participating in the mechanism of $\mathrm{V}(\mathrm{D}) \mathrm{J}$ recombination and while some genes are novel candidates, some others are important components for the repair of DSB via NHEJ, thus strongly suggesting an overlap between the two processes. These results open new perspectives for further studies on the specific roles of these genes, using strategies of gene silencing, such as RNA interference.

\section{Acknowledgements}

This research was supported by the Brazilian agencies Fundação de Amparo à Pesquisa do Estado de São Paulo (Fapesp, \#99/12135-9) and Conselho Nacional de Desenvolvimento Científico e Tecnológico (CNPq) and is part of the $\mathrm{PhD}$ thesis of RSC who received a pre-doctoral fellow from Fapesp (\#00/09994-9). We would like to thank Mrs. Geneviève Victorero, Mrs. Beatrice Loriod and Mr. Fabrice Lopez, Unité INSERM ERM 206, Marseille, France, for technical assistance and discussions. 


\section{References}

Bertucci, F., Houlgatte, R., Granjeaud, S., et al., 2002. Prognosis of breast cancer and gene expression profiling using DNA arrays. Ann. N. Y. Acad. Sci. 975, 217-231.

Chaudhuri, J., Alt, F.W., 2004. Class-switch recombination: interplay of transcription, DNA deamination and DNA repair. Nat. Rev. Immunol. 4, 541-552.

DeLuca, D., Bluestone, J.A., Schultz, L.D., Sharrow, S.O., Tatsumi, Y., 1995. Programmed differentiation of murine thymocytes during fetal thymus organ culture. J. Immunol. Methods 178, 13-29.

Eisen, M., Spellman, P., Brown, P., Botstein, D., 1998. Cluster analysis and display of genome-wide expression patterns. Proc. Natl. Acad. Sci. U.S.A. 95, 14863-14868.

Espanhol, A.R., Cardoso, R.S., Junta, C.M., Victorero, G., Loriod, B., Nguyen, C., Passos, G.A.S., 2004. Large scale gene expression analysis of $\mathrm{CBA} / \mathrm{J}$ mouse strain fetal thymus using cDNA-array hybridizations. Mol. Cell. Biochem. 260, 65-68.

Espanhol, A.R., Macedo, C., Junta, C.M., Cardoso, R.S., Victorero, G., Loriod, B., Nguyen, C., Jordan, B., Passos, G.A.S., 2003. Gene expression profiling during thymus ontogeny and its association with TCRVB8.1-DB2.1 rearrangements of inbred mouse strains. Mol. Cell. Biochem. 252, 223-228.

Fink, P.J., McMahan, C.J., 2000. Lymphocytes rearrange, edit and revise their antigen receptors to be useful yet safe. Immunol. Today 21, 561-566.

Fugmann, S.D., 2002. Breaking the seal. Nature 416, 691-694.

Gontijo, A.M.M.C., Green, C.M., Almouzni, G., 2003. Repairing DNA damage in chromatin. Biochimie 85, 1133-1147.

Grawunder, U., Wilm, M., Wu, X., Kuleska, P., Wilson, T.E., Mamm, M., Lieber, M.R., 1997. Activity of DNA ligase IV stimulated by complex formation with XRCC4 protein in mammalian cells. Nature 388, 492-495.

Hempel, W.M., Stanhope-Baker, P., Mathieu, N., Huang, F., Schlissel, M.S., Ferrier, P., 1998. Enhancer control of V(D)J recombination at the TCR beta locus: differential effects on DNA cleavage and joining. Genes Dev. 12, 2305-2317.

Jeggo, P., Concannon, P., 2001. Immune diversity and genomic stability: Opposite goals but similar paths. J. Photochem. Photobiol. 65, 88-96.

Junta, C.M., Passos, G.A.S., 1998. Emergence of TCR V(D)J recombination and transcription during ontogeny of inbred mouse strains. Mol. Cell. Biochem. 187, 67-72.

Lees-Miller, S.P., Meek, K., 2003. Repair of DNA double strand breaks by non-homologous end joining. Biochimie 85, 1161-1173.

Lefranc, M.P., Lefranc, G., 2001. The T-cell Receptors Facts Book, first ed. Academic Press Suffolk, London.
Macedo, C., Junta, C.M., Passos, G.A.S., 1999. Onset of T-cell receptor VB8.1 and DB2.1 V(D)J recombination during thymus development of inbred mouse strains. Immunol. Lett. 69, 371-373.

Magalhães, D.A.R., Macedo, C., Junta, C.M., Mello, S.S., Marques, M.M.C., Cardoso, R.S., Sakamoto-Hojo, E.T., Donadi, E.A., Passos, G.A.S., 2005. Hybridization signatures during thymus ontogeny reveals modulation of genes coding for T-cell signaling proteins. Mol. Immunol. 42, 1043-1048.

Moshous, D., Callebaut, I., Chasseval, R., Corneo, B., Cavazzana-Calvo, M., Le Deist, F., Tezcan, I., Sanal, O., Bertrand, Y., Philippe, N., Fischer, A., De Villartay, J.P., 2001. Artemis, a novel DNA doublestrand break repair/V(D)J recombination protein, is mutated in human severe combined immune deficiency. Cell 105, 177-186.

Muegge, K., Vila, M.P., Durum, S.K., 1993. Interleukin-7: a cofactor for V(D)J rearrangement of the T-cell receptor gene. Science 261, 93-95.

Nguyen, C., Rocha, D., Granjeaud, S., Baldit, M., Bernard, K., Naquet, P., Jordan, B.R., 1995. Differential gene expression in the murine thymus assayed by quantitative hybridization of arrayed cDNA clones. Genomics 29, 207-216.

Pastwa, E., Blasiak, J., 2003. Non-homologous DNA end joining. Acta Biochim. Pol. 50, 891-908.

Prise, K.M., Pinto, M., Newman, H.C., Michael, B.D., 2001. A review of studies of ionizing radiation-induced double-strand break clustering. Radiat. Res. 156, 572-576.

Quackenbush, J., 2002. Microarray data normalization and transformation. Nat. Genet. 32 (Suppl.), 496-501.

Rugh, R., 1968. The Mouse. Its Reproduction and Development. Burgess Publishing Company.

Schlissel, M., Constantinesai, A., Morrow, T., Baxter, M., Peng, A., 1993. Double-strand signal sequence breaks in V(D)J recombination are blunt $5^{\prime}$-phosphorylated, RAG-dependent, and cell-cycle regulated. Genes Dev. 7, 2520-2532.

Sollof, R.S., Wang, T.G., Dempsey, D., Jennings, S.R., Wolcott, R.M., Chervenak, R., 1997. Interleukin 7 induces TCR gene rearrangement in adult marrow-resident murine precursor T cells. Mol. Immunol. 34, 453-462.

Tapias, A., Auriol, J., Forget, D., Enzlin, J.H., Scharer, O.D., Coin, F., Coulombe, B., Egly, J.M., 2004. Ordered conformational changes in damaged DNA induced by nucleotide excision repair factors. J. Biol. Chem. 279, 19074-19083.

Toki, J., Adachi, Y., Jin, T., Fan, T., Takase, K., Lian, Z., Hayashi, H., Gershwin, M.E., Ikehara, S., 2003. Enhancement of IL-7 following irradiation of fetal thymus. Immunobiology 207, 247-258.

Verdeil, G., Puthier, D., Nguyen, C., 2002. Gene profiling approach to establish the molecular basis for partial versus full activation of naïve CD8 T lymphocytes. Ann. N. Y. Acad. Sci. 975, 68-76. 


\section{Onset of promiscuous gene expression in murine fetal thymus organ culture}

Renato Sousa Cardoso, ${ }^{1 \star}$ Danielle A. R. Magalhães, ${ }^{1 \star}$ Ana Maria T. Baião, ${ }^{1 \star}$ Cristina Moraes Junta, ${ }^{1}$ Claudia Macedo, ${ }^{1}$ Márcia M. C. Marques, ${ }^{1}$ Elza Tiemi SakamotoHojo, ${ }^{2,3}$ Eduardo A. Donadi ${ }^{4}$ and Geraldo A. S. Passos ${ }^{1,5}$

${ }^{1}$ Molecular Immunogenetics Group, Department of Genetics, Faculty of Medicine,

${ }^{2}$ Laboratory of Cytogenetics and Mutagenesis Department of Genetics, Faculty of Medicine, ${ }^{3}$ Department of Biology (FFCLRP), ${ }^{4}$ Department of Medicine, Faculty of Medicine, and ${ }^{5}$ Discipline of Genetics (DMEF), Faculty of Dentistry, University of São Paulo, Ribeirão Preto, SP, Brazil

doi:10.1111/j.1365-2567.2006.02441.x Received 4 January 2006; revised 27 June 2006; accepted 28 June 2006.

${ }^{\star}$ These authors contributed equally to this work.

Correspondence: Dr Geraldo A. S. Passos, Molecular Immunogenetics Group,

Department of Genetics, Faculty of Medicine, 14040-900, Ribeirão Preto, SP, Brazil.

Email: passos@rge.fmrp.usp.br

Senior author: Dr Geraldo A. S. Passos

\begin{abstract}
Summary
T-cell differentiation and induction of tolerance to self-antigens occurs mainly in the thymus. Thymic stromal cells, specifically medullary thymic epithelial cells, express a diverse set of genes encoding parenchymal organ-specific proteins. This phenomenon has been termed promiscuous gene expression (PGE) and has been implicated in preventing organspecific autoimmunity by inducing T-cell tolerance to self antigens. Early thymopoiesis and the critical factors involved in T-cell differentiation can be reproduced in vitro by murine fetal thymus organ culture (FTOC), which mimics the natural thymic microenvironment. To evaluate the occurrence of PGE in FTOC, gene expression profiling during in vitro thymic development in $\mathrm{BALB} / \mathrm{c}$ mice was performed using a set of nylon cDNA microarrays containing 9216 sequences. The statistical analysis of the microarray data (SAM program) revealed the temporal repression and induction of 57 parenchymal and seven lymphoid organ-specific genes. Most of the genes analysed are repressed during early thymic development (1517 days post-coitum). The expression of the autoimmune regulator (AIRE) gene at 16 days post-coitum marks the onset of PGE. This precedes the induction of parenchymal organ genes during the late developmental phase at 20 days post-coitum. The mechanism of T-cell tolerance induction begins during fetal development and continues into adulthood. Our findings are significant because they show a fine demarcation of PGE onset, which plays a central role in induction of T-cell tolerance.
\end{abstract}

Keywords: cDNA microarray; fetal thymus organ culture; promiscuous gene expression; thymus; T-cell tolerance

\section{Introduction}

The thymus is the key primary lymphoid organ that is mainly involved in the progressive differentiation of thymocytes to mature $\mathrm{T}$ cells in which all developmental stages are distinguishable by their expression of a combination of clusters of differentiation (CD) cell-surface markers. Studies with freshly obtained fetal thymus allowed for the demarcation of T-cell receptor $\beta \mathrm{V}(\mathrm{D}) \mathrm{J}$ recombination during in vivo thymus ontogeny among different inbred mouse strains; this contributed to the revealing of the effect of the genetic background on T-cell development. ${ }^{1-3}$ The control of gene expression during the development of this organ has gained priority among several research groups, including our own, leading to the identification of candidate genes involved in thymopoiesis. Using the cDNA microarray method, a dozen expressed sequence tags have been found that are modulated during the in vivo development of the thymus. ${ }^{4}$ Using the same kind of analysis, the in vivo modulation of several cell-signalling genes was identified, including those of the calcium cascade pathway, which is important for individual stages of T-cell maturation and the control of anergy during murine thymus ontogeny. ${ }^{5}$

Meanwhile, a better understanding of the central tolerance mechanism, that is, all the mechanisms by which $\mathrm{T}$ cells contribute to self-tolerance by intrathymic recognition of self-antigens, emerged from evidence that 
tissue-specific antigens are expressed in the thymus and contribute to the selection of the T-cell repertoire. These tissue-specific antigens are expressed as a normal physiological property of thymic epithelial cells (TECs). ${ }^{6}$ This phenomenon was termed promiscuous gene expression (PGE), which includes self antigens that represent most of the parenchymal organs. ${ }^{7-14}$ Evidence of PGE in the thymus is causing a reversal in our understanding of central tolerance, allowing for an unorthodox conception of the possible mechanism of self-non-self discrimination. ${ }^{15,16}$

The initial evidence for promiscuously expressed genes was biased towards antigens involved in autoimmune reactions, such as insulin, acetylcholine receptor or myelin basic protein. Today it is recognized that rather than being selective, the set of expressed genes is as broad as possible, estimated to include up to $5-10 \%$ of all currently known mouse genes. ${ }^{9}$ Thus, the main implication of this heterogeneous gene expression in the thymus is associated with maintenance of the immunological homeostasis in the body, controlling pathogenic autoimmune reactions.

Studies on thymus gene expression in the broadest aspect, including PGE, are normally designed to be performed immediately using samples collected by surgery, which must reflect the short-term in vivo situation.

Nevertheless, fetal thymus organ culture (FTOC), introduced by DeLuca's group, ${ }^{17}$ which is based on the use of early fetal thymus tissue, preserves the original architecture of the thymus, with its cellularity formed of stromal TECs and homogeneous thymocyte population doublenegative cells. This is a singular, powerful culture model system reproducing intrathymic T-cell development in vivo, making it easier to study the candidate genes implicated in normal thymus development. Using the cDNA microarray method, our group recently showed the modulation of gene expression in murine FTOCs at the transcriptome level and revealed an overlap between genes associated with $\mathrm{T}$-cell receptor $\mathrm{V}(\mathrm{D}) \mathrm{J}$ recombination and DNA repair. We showed that the association of FTOC and cDNA microarray technology allows sufficient accuracy to uncover the participation of essential genes implicated in thymus development. ${ }^{18}$

In the present study, cDNA microarrays were employed to observe the onset of PGE during the in vitro development of murine thymus in FTOCs. Comparing the time of thymus gestation as a result of fetal age and culture duration, it was possible to discover the onset of gene induction, representing 57 different parenchymal and seven lymphoid organs. Some coded proteins are considered to be tissue-specific antigens, thus indicating that FTOCs reproduce promiscuous gene expression.

The FTOC transcriptome profiling was assessed using a set of six nylon cDNA microarrays containing a total of 9216 IMAGE thymus sequences. PGE was identified on the basis of gene expression data for different parenchymal organs. To our knowledge, these findings represent the first demonstration of the temporal beginning of PGE in murine FTOC. Moreover, the importance of this event is associated with the fact that this model system could be a useful tool for testing cytokines, RNA interference or other compounds that directly control gene expression in the thymus, as possible modulators of PGE.

\section{Material and methods}

\section{FTOCs and total RNA preparation}

$\mathrm{BALB} / \mathrm{c}$ mice were bred in an isolator with $0 \cdot 45-\mu \mathrm{m}$ poresize air filtered in our own breeding facility. To obtain timed pregnancies, the mice were mated and the day when the vaginal plug was observed at 7:00 hr was considered to be day zero of gestation post-coitum (p.c.). The pregnant mice were killed by ether inhalation and the fetuses were collected via surgery of the uterus. The p.c. age of the fetuses was confirmed by the morphological characteristics of each developmental phase. ${ }^{18,19}$ The thymi were removed from the fetuses under a stereomicroscope and cultured according to the organ culture technique previously described. ${ }^{17}$

Briefly, the organs were dissected and cleaned from the adjacent tissue and placed on the surface of Millipore filters $(0.45 \mu \mathrm{m}$ pore size $)$ pre-embedded with culture medium. These filters were supported on plastic grids in $2 \mathrm{ml}$ Dulbecco's modified Eagle's medium/HAM F-10 culture medium (Gibco, Gaithersburg, MD, USA) supplemented with $20 \%$ heat inactivated fetal bovine serum (Biobrás, Montes Claros, MG, Brazil) in 24-well tissue culture plates. The medium was also supplemented with $100 \mu \mathrm{g} / \mathrm{ml}$ streptomycin, $250 \mathrm{U} / \mathrm{ml}$ penicillin, $10 \mu \mathrm{g} / \mathrm{ml}$ gentamicin, $1 \mathrm{~mm}$ sodium pyruvate, $20 \mu \mathrm{M} 2$-mercaptoethanol and $3.4 \mathrm{~g} / \mathrm{l}$ sodium bicarbonate. The incubation time of the organ culture varied from 2 to 5 days at $37^{\circ}$ in a $5 \% \mathrm{CO}_{2}$ incubator.

Thymi were dissected from fetuses obtained at 13, 14 and 15 days of gestation and cultured for 2 days, so mimicking 15, 16 and 17 days p.c. of in vivo development, respectively. Thymi from 15-day p.c. fetuses were also cultured for 5 days, mimicking the 20th day of in vivo development, and in this case, the culture medium was changed on the third day of incubation.

To evaluate the viability of FTOCs, three randomly selected thymi from each group were used for the single cell suspension preparations, which were separately stained with acridine orange $(100 \mu \mathrm{g} / \mathrm{ml})$ or with ethidium bromide $(100 \mu \mathrm{g} / \mathrm{ml})$ and analysed on an Axiophot II fluorescence microscope (Carl Zeiss, Oberkochen, Germany) to evaluate the frequency of apoptosis and necrosis, respectively. Total RNA samples were prepared from FTOCs using Trizol ${ }^{\circledR}$ reagent according to the manufacturer's instructions (Invitrogen, Carlsbad, CA, USA). 


\section{cDNA microarray method}

A set of six microarrays were used containing a total of 9216 cDNA sequences (1536 sequences each) in the form of polymerase chain reaction (PCR) products, spotted in duplicate on $2.5 \times 7.5 \mathrm{~cm}$ Hybond $\mathrm{N}+$ nylon membranes (GE Healthcare, Amersham, UK). The arrays were prepared in our laboratory using a Generation III Array Spotter (Amersham Biosciences-Molecular Dynamics, Sunnyvale, CA, USA).

Mouse thymus expressed sequence tag cDNA clones were obtained from the Soares thymus 2NbMT normalized library, prepared from the thymus of a C57BL/6J 4-week-old male mouse, and available from the IMAGE Consortium (http://image.llnl.gov/image/html/iresources. shtml) and from the RZPD Deutsches Resourcenzentrum für Genomforschung GmbH (http://www.rzpd.de).

The cDNA inserts were homogeneous in size (near $1 \mathrm{~kb}$ ), cloned in three vectors (pT7T3D, pBluescript and Lafmid) and were amplified in 384- or 96-well plates using vector-PCR amplification with the following primers, which recognize the three vectors: LBP $1 S$ GTGGAATTGTGAGCGGATACC forward and LBP 1AS GCAAGGCGATTAAGTTGG reverse. This set of cDNAs included sequences of some known autoantigens, such as small nuclear ribonucleoprotein SMD1, lupus Ku protein p70, p80 and p86 and PM-SCL; the full list of cDNA sequences used to prepare the microarrays can be retrieved online at http://rge.fmrp.usp.br/passos/mtb_library.

The membranes were first hybridized with LBP 1AS $\left[\gamma_{-}{ }^{33} \mathrm{P}\right] \mathrm{dCTP}-$ labelled oligonucleotide (vector hybridization). Quantification of the signals obtained allowed for the estimation of the amount of cDNA insert fixed in each spot. After stripping, the membranes were used for hybridization with cDNA complex probes (sample hybridization). The characterization of each cDNA sequence was updated using the ELOGE ${ }^{\circledR}$ (Ipsogen, Marseille, France, http://www.ipsogen. fr) software, which runs on our local server and links each clone ID with the genome data banks (http://genomewww5.stanford.edu/cgi-bin/source/sourceSearch), providing information such as DNA and protein sequences, biological and molecular functions and chromosomal location.

\section{Complex cDNA probe preparation and hybridization}

In this study, we refer to the radioactive cDNA originated from the thymus RNA samples (FTOCs) as complex probe and to the PCR product originated from the clones and deposited on nylon microarrays as target.

The ${ }^{33} \mathrm{P}$-labelled cDNA complex probes were prepared by reverse transcription of $10 \mu \mathrm{g}$ thymus total RNA using oligo-dT(12-18) as a primer; $100 \mu \mathrm{l}{ }^{33} \mathrm{P}-\mathrm{cDNA}$ complex probe containing $30-50$ million counts per minute was hybridized with nylon microarrays as previously described. $^{20-22}$

\section{cDNA microarray image acquisition}

Imaging plates and a phosphor imager apparatus (Packard Phosphor Imager, model Cyclone, Packard Instruments, Downers Grove, IL, USA) were used to capture the hybridization signals and the BZScan software ${ }^{23}$ was used to quantify the signals with local background subtraction, whose spots were matched with a template grid. The ratio between vector probe hybridization values and complex probe hybridization values for each spot was used as a reference normalization value. Total intensity normalization was also employed, using the median expression value. ${ }^{24}$

\section{Significance analysis of microarray data}

The gene expression data analysed here were obtained from six independent determinations for each day of fetal development in FTOC. The SAM method ${ }^{25}$ (Significance Analysis of Microarrays, available at http://www.stat. stanford.edu/ tibs/SAM/index.html) was used to analyse significant variations in gene expression. This method is based on $t$-test statistics, specially modified for high throughput analysis. The significant variations in the gene expression of developing thymus in FTOCs were compared using the 15 -day p.c. as reference (15 versus 16,15 versus 17 and 15 versus 20 days of development). In this study, only those genes presenting a two-fold change of expression (either repressed or induced) and a gene error chance ( $q$-value) equal to 0.01 (see Supplementary Table S1) were considered.

\section{Determination of PGE in the thymus}

PGE was identified on the basis of data from microarray analysis of the different mouse organs using combined information from the public database GNF Gene Expression Atlas $^{26}$ (http://symatlas.gnf.org/SymAtlas). This data bank shows gene expression in more than 60 mouse tissues/organs, as assessed by gene array analysis using Affymetrics microarrays. Data information includes GenBank accession, chromosomal location and the molecular/biological function of each gene analysed (Table S1).

In this study, only the promiscuous genes of which the expression was detected in different organs or tissues, besides the thymus, and of which the expression levels were greater than median in relation to all other organs which appear in the GNF Atlas were considered. The modulation of transcription levels (repression or induction) of these genes was evaluated during FTOC development.

\section{Semi-quantitative reverse transcription-PCR} (SQ RT-PCR)

The zinc finger protein 369 gene (ZNF 369; acc NM_178364, clone ID 573600) that was found to be 
induced in the microarray experiments and the AIRE gene (acc NM_009646) were tested by SQ RT-PCR; $1 \mu \mathrm{g}$ total RNA from each developmental phase in FTOC was copied to cDNA by reverse transcription using oligo-dT(12-18) as a primer. One microlitre of successive dilutions of the cDNA $(1: 2$ to $1: 128)$ were used as a PCR template. PCRs were performed in a final volume of $25 \mu \mathrm{l}$ containing $100 \mu \mathrm{M}$ each dNTP, $1 \mu \mathrm{M}$ each primer and $1 \mathrm{U}$ Taq DNA polymerase (Amersham Biosciences).

The amplification protocol for the ZNF 369 and AIRE genes assayed was as follows; one cycle at $94^{\circ}$ for $5 \mathrm{~min}$, 30 cycles of $94^{\circ}$ for $1 \mathrm{~min}, 55^{\circ}$ for $1 \mathrm{~min}$, then $72^{\circ}$ for $1 \mathrm{~min}$, and then one cycle at $72^{\circ}$ for $10 \mathrm{~min}$ then $4^{\circ}$ for $10 \mathrm{~min}$. The amplification was terminated with a final incubation step at $72^{\circ}$ for $10 \mathrm{~min}$.

Aliquots of the PCR products were mixed with $1 \mu \mathrm{l}$ of a diluted solution of ethidium bromide, resolved on $2 \%$ agarose gel electrophoresis using $1 \times$ TAE buffer. The gels were visualized on a UV transilluminator and the images were captured using a digital camera.

The PCR primers were identified using the PRIMER 3 software (http://frodo.wi.mit.edu/cgi-bin/primer3/primer3_ www.cgi) on the cDNA sequences retrieved from GenBank (http://www.ncbi.nlm.nih.gov) for each gene. The forward and reverse sequences are given in the $5^{\prime}$ to $3^{\prime}$ orientation; ZNF 369 (clone ID 573600, GenBank acc NM_178364) (GGGAGGACCTTATGTGTGT and GGGGCTCTCCTT ATCCAAAAG) and the autoimmune regulator gene, AIRE (GenBank acc NM_009646), although not included in the microarrays, was also assayed with the following primers (CATCCTGGATTTCTGGAGGA and GCTCTTTGAGGC CAGAGTTG).

\section{Results}

\section{Genes differentially expressed during FTOC development}

To identify significant changes in gene expression during fetal development in FTOCs, the early thymus at 15 days was compared with those observed on the subsequent days (15 versus 16,15 versus 17 and 15 versus 20 days p.c. FTOC). A scatter plot of the observed relative difference $d(i)$ against the expected relative difference $d_{E}(i)$ was used, as shown by the SAM program.

Most of the 9216 sequences tested presented $d(i) \cong d_{E}(i)$, indicating that their expression pattern remained unchanged; however, some genes were significantly repressed (154 genes) or induced (38 genes) during FTOC development (Fig. 1).

Interestingly the induction of the 38 genes that include representation of parenchymal organs in the thymus, thus characterizing PGE, was observed at late FTOC (20 days p.c.) (Table S1).

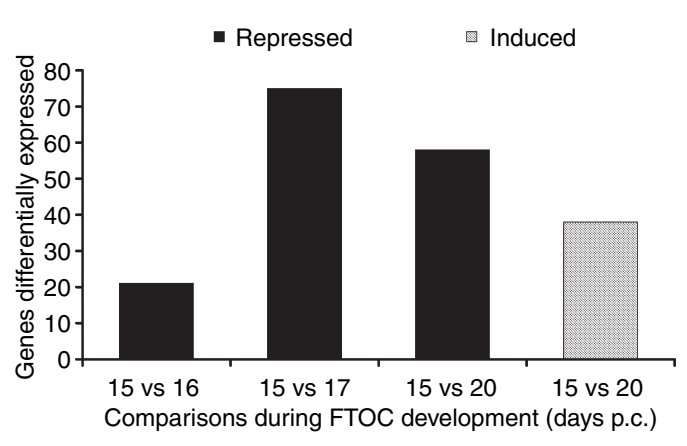

Figure 1. Differential gene expression during the development of FTOC showing that induction of tissue-specific genes emerges at 20 days. Staging corresponds to development of fetal thymus in culture; 15 days FTOC $=13$ days gestation thymus plus 2 days in FTOC.

\section{Gene expression assessed by SQ RT-PCR}

The ZNF 369 gene (acc NM_178364) was selected to confirm the respective result obtained with the cDNA microarray. SQ RT-PCR evaluation confirmed that this gene was induced at 20 days p.c. FTOC (Fig. 2a). Moreover, the AIRE gene (acc NM_009646) began its expression at 16 days p.c. FTOC (Fig. 2b).

\section{Parenchymal organ representation in the thymus}

The 38 genes identified as significantly induced at 20 days p.c. in FTOC were assigned to 57 parenchymal and seven lymphoid organs according to their predominant expression, which were subgrouped in 17 systems. Interestingly, central nervous and reproductive systems and glands are the predominant parenchymal organs represented in the thymus at this phase of development, followed by the lymphoid system (Fig. 3). Four genes; small nuclear ribonucleoprotein D1, acc NM_009226; CD27 antigen, acc L24495; Riken cDNA 1110065L07, acc AA119642; and D-amino-acid oxidase, acc AI447515; code for tissuespecific antigen proteins, because they are expressed in only five or six tissues (Table S1).

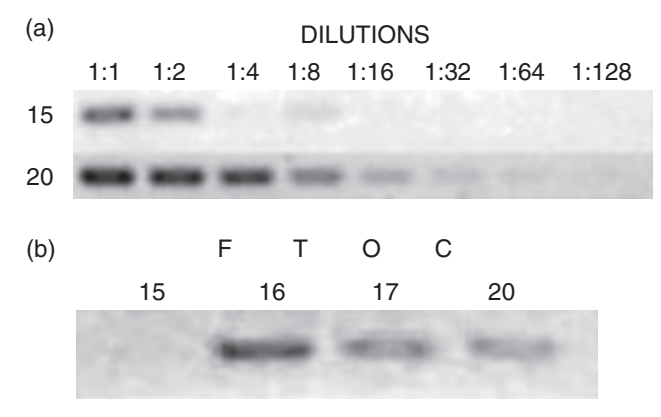

Figure 2. Semi-quantitative reverse transcription-PCR. Confirmation of $Z N F$ gene as induced at 20 days FTOC (a) and emergence of AIRE gene expression at 16 days FTOC (b). 


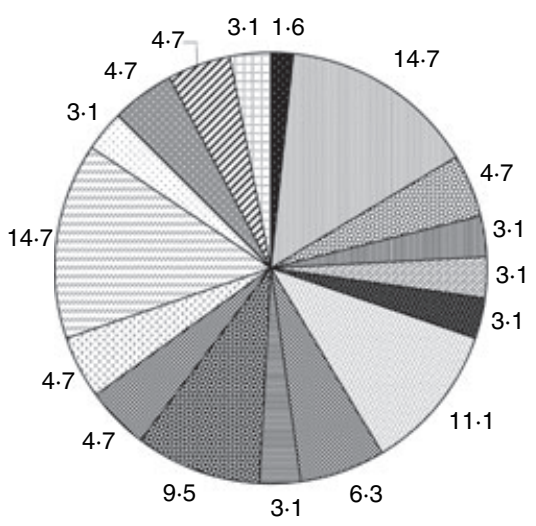

- Circulatory

- Central Nervous

a Digestive

- Epidermis/Skin

a Eyes

- Fat tissue

ธ Glands

- Intestines

- Locomotory

- Lymphoid

- Muscles

匹 Peripheral Nervous

$\square$ Reproductive

$\square$ Respiratory

- Sensory Organs

a Stem cells

u Urinary

Figure 3. Representation of tissue/organ system-specific gene expression in 20 days FTOC.

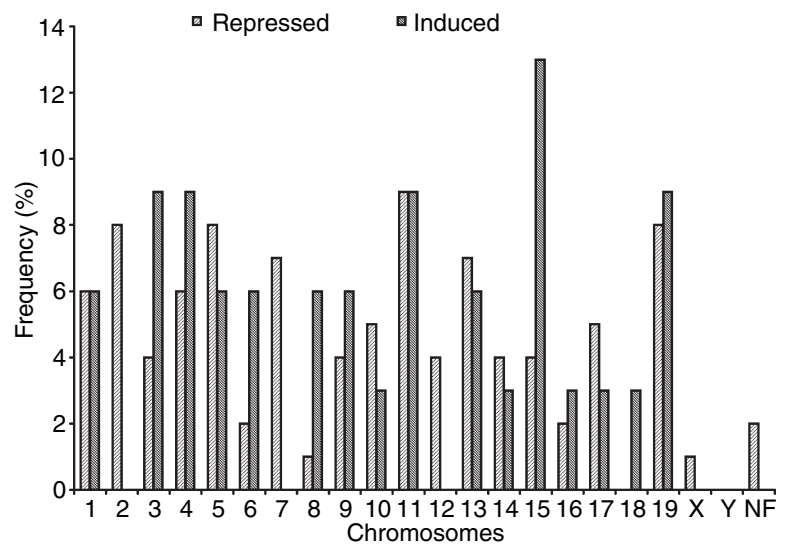

Figure 4. Chromosomal distribution of the repressed and induced genes considering all FTOC development (15-20 days).

NF, not found.

\section{Chromosomal location of differentially expressed genes}

The genomic distribution of the 192 genes modulated (repressed or induced) during the 5 days of FTOC development allowed for the co-ordinated expression of organizing chromosomal clusters.

Figure 4 shows the frequency distribution of the repressed and induced genes among chromosomes. Taking all the developmental phases together, the number of repressed genes (154) was greater than that of induced genes (38). All chromosomes, except $\mathrm{Y}$, harboured differentially expressed genes, with a slightly biased distribution on chromosomes 2, 5, 11 and 19 for repressed genes and on chromosomes 3, 4, 11, 15 and 19 for induced genes.

\section{Discussion}

PGE in the thymus is a complex phenomenon observed in humans and mice, which is exhibited by TECs (mTECs) and involves $5-10 \%$ of all known genes of these species. This process is a guarantee of self-representation of most parenchymal tissues and organs during the central tolerance of $\mathrm{T}$ cells.

Using PCR, Derbinski's group previously demonstrated that the expression of five tissue-specific genes, such as thyroglobulin, CRP, GAD67, insulin and albumin, was detectable only in mTECs purified from ex vivo thymic tissue at embryonic day 15 (E15). ${ }^{7}$

Accordingly, the complexity of PGE increases in, from cTECs to immature mTECs to mature CD $80^{\text {hi }}$ mTECs. These different gene pools are not complementary, but additive, that is, there is no apparent association between the respective molecular/biological functions of the genes in parenchymal organs. The significance of PGE in the thymus is associated with the central tolerance of $\mathrm{T}$ cells. $^{9-14}$

While PGE by mTECs was well documented by the authors cited above, many aspects of this phenomenon remain unexplored, for example, its evaluation in the thymus of autoimmune strains and/or knockout mice, its modulation by means of cytokines or other molecules interfering in gene expression, such as RNA interference, and its time-course during the ontogenetic development of the thymus.

Molecular characterization of PGE in the FTOC model system is a relevant approach in immunobiology, because the functional analysis of T-cell development has become possible after the introduction of techniques in which the thymic microenvironment is mimicked, such as FTOC. This method is based on the use of early fetal thymus tissue, which is composed of a homogeneous thymocyte population (double-negative cells).

In this study, the occurrence of PGE in vitro in FTOC is described for the first time. To evaluate whether PGE in this model system is a development-dependent phenomenon, we regarded the differential gene expression during ontogeny by comparing days of gestation (p.c.), as the most informative in the delineation of the gene pool. Use of the FTOC model system was chosen, rather than compare the changes in expression profiles in thymus tissue obtained at different gestational days, to approach three important aspects simultaneously. Since FTOC reproduces the in vivo thymus development, this model system represented a useful tool first, for the fine demarcation of PGE onset and, second, to demonstrate that PGE is a phenomenon that can be reproduced in vitro. The third aspect was a beneficial possibility of the FTOC model system, comparing the same pool of thymus tissue at day 15 with later time-points.

We demonstrated that PGE in FTOC, which is characterized by the overexpression of parenchymal organ and tissue-specific antigen genes, emerges at 20 days p.c. (Fig. 1). Since this in vitro organ culture mimicked the thymus gestation in vivo, including the maturation of $\mathrm{T}$ 
cells, ${ }^{18}$ these results strongly suggest that PGE is dependent on thymus maturation. The significance of these findings is associated with the timing of T-cell tolerance induction during ontogeny. T-cell receptor $\beta$ rearrangements emerge at 16 days p.c. in vivo and in FTOC in BALB/c mice. ${ }^{1-3,18}$

The early fetal thymus, by $13-15$ days p.c., is composed of homogeneous double-negative $\mathrm{CD}^{-} \mathrm{CD}^{-}$ T-cell precursors; however, by day 18 p.c. this population gradually acquires the CD4 marker resembling the adult CD4 ${ }^{\text {low }}$ precursor. ${ }^{26,27}$ These features allow for T-cell receptor-major histocompatibilty complex peptide recognition and enable the positive/negative selection of $\mathrm{T}$ cells in fetal thymus. Our evidence for the occurrence of PGE in late fetal thymus is associated with the timing of the molecular events of T-cell tolerance induction during ontogeny.

The data collected here were obtained using the cDNA microarray method, with the expression of the 9216 sequences analysed by the SAM algorithm. ${ }^{25}$ Considering 15 days p.c. FTOC as a reference, it was possible to make comparisons with the subsequent days of development. A statistically significant set of 154 repressed genes were found between 15 and 17 days p.c. and 38 genes were considered as overexpressed at 20 days p.c. FTOC, indicating the emergence of PGE (Table S1).

Moreover, these findings are important to the PGE differentiation model in the thymus and the concomitant increased $A I R E$ gene expression in the most mature mTECs. In the FTOC model system studied, AIRE gene expression begins at 16 days p.c., before a significant induction of parenchymal and tissue-specific antigen genes (Fig. 2b), suggesting that this gene could be associated with the control of the parenchymal organ gene expression observed. ${ }^{28}$

Although the experiments were not conducted with purified mTECs, this caused no problems regarding PGE detection in the thymus. To bypass this potential difficulty, a cDNA microarray method was used, including a dedicated statistical algorithm for data analysis (SAM algorithm), which presented sufficient accuracy to distinguish and quantify parenchymal organ gene expression originating from thymic epithelial cells, especially mTECs. ${ }^{8,9,13}$

The cDNA microarray data mining has permitted the virtual dissection of the mouse thymus into its principal cellular components by means of the identification of the specific cellular transcripts (mRNAs). ${ }^{29}$ These observations demonstrate the feasibility for the use of whole thymus as starting material in PGE studies.

Moreover, we selected a gene found in the microarray experiments (ZNF 369) that is representative of parenchymal organs, whose modulation in the expression was confirmed by SQ-RT-PCR (Fig. 2a).

In agreement with previous observations, ${ }^{13}$ the molecular/biological function of promiscuously expressed genes found in the present model system showed no interrelationship (Table S1).

Regarding the chromosomal localization of the repressed and induced genes, no important preferential distribution was identified. All chromosomes harbour promiscuously expressed genes with a slightly biased distribution on chromosomes 2, 5, 11 and 19 among the repressed genes and on chromosomes 3, 4, 11, 15 and 19 among the induced genes. The exceptions were chromosome $\mathrm{Y}$, on which no repressed or induced genes were identified, and chromosome 2, on which no induced genes were positioned (Fig. 4).

This feature of random PGE distribution in the genome strongly suggests an uncommon model of gene regulation found in the thymus, which requires further investigation, including the elucidation of the molecular mechanism of the AIRE gene action.

The model system presented here was important to demonstrate that PGE is a differentially controlled phenomenon, ${ }^{9}$ beginning in BALB/c mice at 20 days p.c. (FTOC), and because this phenomenon can be reproduced in vitro, these findings raise the possibility of testing the induction of gene expression alteration caused by FTOC cytokine treatment or selected gene transfections that could modulate PGE. Recent evidence for a second thymus in mice ${ }^{30}$ increase the possibility of further research into their contribution to self-tolerance mechanisms, including determination of occurrence of the PGE in this organ.

\section{Acknowledgements}

This research was funded by the Brazilian agencies FAPESP (Fundação de Amparo à Pesquisa do Estado de São Paulo) through thematic project (99/12135-9) and doctorate fellowships to R.S.C., D.A.R.M., C.M.J., and M.M.C.M. and the $\mathrm{CNPq}$ (Conselho Nacional de Desenvolvimento Científico e Tecnológico) to C.M. The IMAGE cDNA library used was kindly ceded by Dr Catherine Nguyen of the Unité INSERM ERM 206, Marseille, France.

\section{References}

1 Junta CM, Passos GAS. Emergence of TCR $\alpha \beta$ V (D) J recombination and transcription during thymus ontogeny of inbred mouse strains. Mol Cell Biochem 1998; 187:67-72.

2 Macedo C, Junta CM, Passos GAS. Onset of T-cell receptor $\mathrm{V} \beta 8.1$ and $\mathrm{D} \beta 2.1, \mathrm{~V}(\mathrm{D}) \mathrm{J}$ recombination during thymus development of inbred mouse strains. Immunol Lett 1999, 69:371-3.

3 Espanhol AR, Macedo C, Junta CM, et al. Gene expression profiling during thymus ontogeny and its association with TRVB8DB2.1 rearrangements of inbred mouse strains. Mol Cell Biochem 2003; 252:223-8.

4 Espanhol AR, Cardoso RS, Junta CM, Victorero G, Loriod B, Nguyen C, Passos GAS. Large scale gene expression analysis of CBA/J mouse strain fetal thymus using cDNA-array hybridizations. Mol Cell Biochem 2004; 206:65-8. 
5 Magalhães DA, Macedo C, Junta CM, et al. Hybridization signatures during thymus ontogeny reveals modulation of genes coding for T-cell signaling proteins. Mol Immunol 2005; 42:1043-8.

6 Jolicoeur C, Hanahan D, Smith KM. T-cell tolerance toward a transgenic $\beta$-cell antigen and transcription of endogenous pancreatic genes in thymus. Proc Natl Acad Sci USA 1994; 91:6707-11.

7 Derbinski J, Schulte A, Kyewski B, Klein L. Promiscuous gene expression in medullary thymic epithelial cells mirrors the peripheral self. Nat Immunol 2001; 2:1032-9.

8 Gotter J, Brors B, Hergenhahn M, Kyewski B Medullary epithelial cells of the human thymus express a highly diverse selection of tissue-specific genes colocalized in chromosomal clusters. J Exp Med 2004; 199:155-66.

9 Kyewski B, Derbinski J. Self-representation in the thymus: an extended view. Nat Rev Immunol 2004; 4:688-98.

10 Sospedra M, Ferrer-Francesch X, Dominguez O, Juan M, Foz-Sala M, Pujol-Borrel R. Transcription of a broad range of self-antigens in human thymus suggests a role for central mechanisms in tolerance toward peripheral antigens. J Immunol 1998; 161:5918-29.

11 Bruno R, Sabater L, Sospedra M, Ferrer-Francesch X, Escudero D, Martínez-Cáceres E, Pujol-Borrel R. Multiple sclerosis candidate autoantigens except myelin oligodendrocyte glycoprotein are transcribed in the human thymus. Eur J Immunol 2002; 32:2737-47.

12 Bruno R, Sabater L, Tolosa E, et al. Different patterns of nicotinic acetylcholine receptor subunit transcription in human thymus. J Neuroimmunol 2004; 149:147-59.

13 Derbinski J, Gäbler J, Brors B, Tierling S, Jonnakuty S, Hergenhahn M, Peltonenh L, Walter J, Kyewski B. Promiscuous gene expression in thymic epithelial cells is regulated at multiple levels. J Exp Med 2005; 202:33-45.

14 Gallegos A, Bevan MJ. Central tolerance: good but imperfect. Immunol Rev 2006; 209:290-6.

15 Kyewski B, Derbinski J, Gotter J, Klein L. Promiscuous gene expression and central T-cell tolerance: more than meets the eye. Trends Immunol 2002; 23:364-71.

16 Mathis D, Benoist C. Back to central tolerance. Immunity 2004; 20:509-16.

17 DeLuca D, Bluestone JA, Schultz LD, Sharoow SO, Tatsumi Y. Programmed differentiation of murine thymocytes during fetal thymus organ culture. J Immunol Meth 1995; 178:13-29.

18 Cardoso RS, Junta CM, Macedo C, et al. Hybridization signatures of gamma-irradiated murine fetal thymus organ culture (FTOC) reveal modulation of genes associated with T-cell recep- tor $\mathrm{V}(\mathrm{D}) \mathrm{J}$ recombination and DNA repair. Mol Immunol 2006; 43:464-72.

19 Rugh R. The Mouse. Its Reproduction and Development, 1st edn. Edina, MN: Burgess Publishing Co., 1968.

20 Nguyen C, Rocha D, Granjeaud S, Baldit M, Bernard K, Naquet $\mathrm{P}$, Jordan BR. Differential gene expression in the murine thymus assayed by quantitative hybridization of arrayed cDNA clones. Genomics 1995; 29:207-15.

21 Bertucci F, Houlgatte R, Granjeaud S, et al. Prognosis of breast cancer and gene expression profiling using DNA arrays. Ann $N$ $Y$ Acad Sci 2002; 975:217-31.

22 Verdeil G, Puthier D, Nguyen C. Gene profiling approach to establish the molecular basis for partial versus full activation of naïve CD8 T lymphocytes. Ann N Y Acad Sci 2002; 975:68-76.

23 Lopez F, Rougemont J, Loriod B, et al. Feature extraction and signal processing for nylon DNA microarrays. BMC Genomics 2004; 29:38.

24 Quackenbush J. Microarray data normalization and transformation. Nat Genet Suppl 2002; 32:496-501.

25 Tusher VG, Tibshirani R, Chu G. Significance analysis of microarrays applied to the ionizing radiation response. Proc Natl Acad Sci USA 2001; 98:5116-21.

26 Su AI, Wiltshire T, Batalov S, et al. A gene atlas of the mouse and human protein-encoding transcriptomes. Proc Natl Acad Sci 2004; 101:6062-7.

27 Shortman K, Wu L. Early T lymphocyte progenitors. Annu Rev Immunol 1996; 14:29-47.

28 Anderson MS, Venanzi ES, Klein L, et al. Projection of an immunological self shadow within the thymus by the aire protein. Science 2002; 298:1395-401.

29 Puthier D, Joly F, Irla M, Saade M, Victorero G, Loriod B, Nguyen C. A general survey of thymocyte differentiation by transcriptional analysis of knockout mouse models. J Immunol 2004; 173:6109-18.

30 Terszowski G, Müller S, Bleul CC, et al. Evidence for a functional second thymus in mice. Science 2006; 312:284-7.

\section{Supplementary material}

The following supplementary material is avaible online for this article:

Table S1. Promiscuously induced genes in 20 days p.c. Balb-c thymus (FTOC).

This material is available as part of the online article from http://www.blackwell-synergy.com 